\title{
A LIDERANÇA DO DOCENTE COMO ELO INTEGRADOR NO PROCESSO ENSINO- APRENDIZAGEM BASEADO EM PROBLEMAS (PROBLEM-BASED LEARNING) EM AMBIENTES HÍBRIDOS NA ENGENHARIA
}

Dissertação apresentada à Escola de

Engenharia de São Carlos da

Universidade de São Paulo, para

obtenção do título de mestre em engenharia de produção

Área de concentração:

Economia, organizações e gestão do conhecimento

Orientador: Prof. Dr. Edson Walmir Cazarini

São Carlos 


\section{AUTORIZO A REPRODUÇĀO TOTAL OU PARCIAL DESTE TRABALHO, POR QUALQUER MEIO CONVENCIONAL OU ELETRÔNICO, PARA FINS DE ESTUDO E PESQUISA, DESDE QUE CITADA A FONTE.}

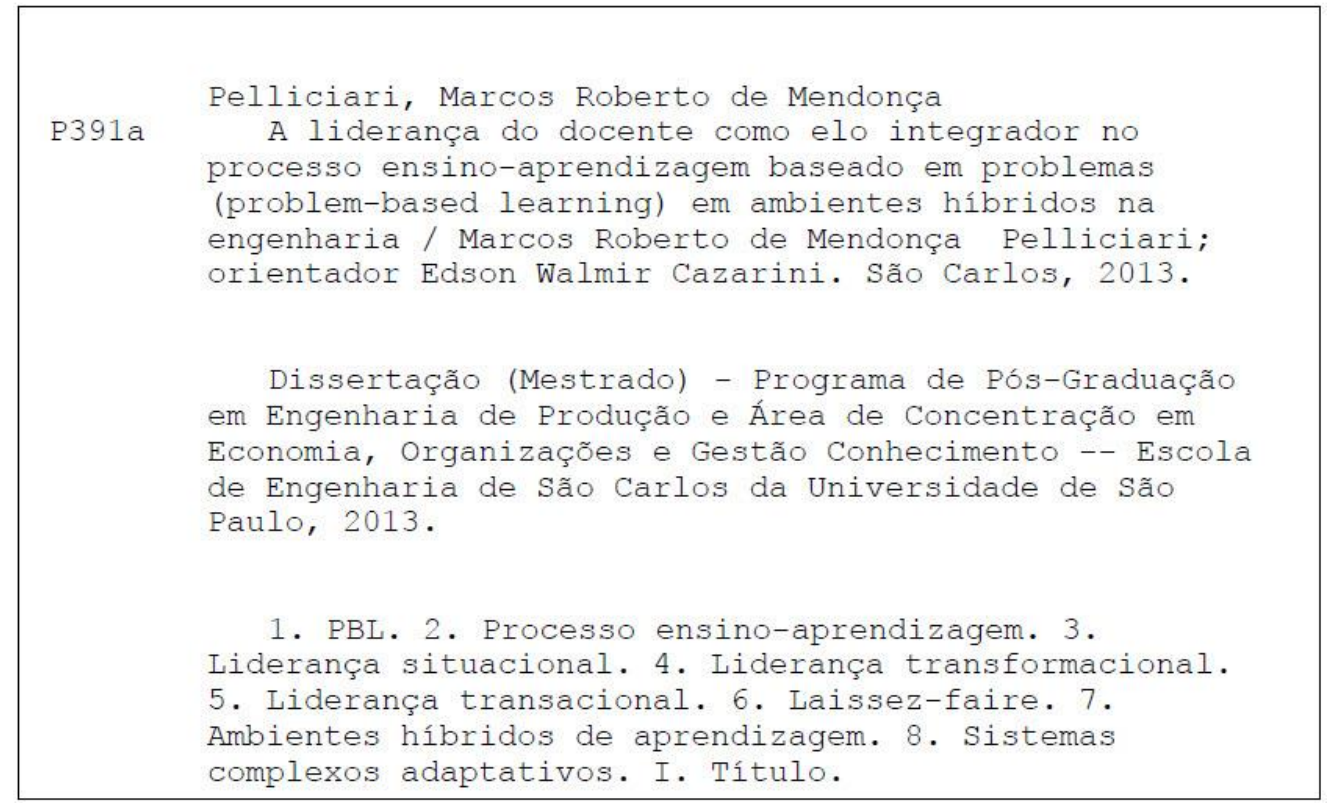




\section{FOLHA DE IULGAMENTO}

\section{Candidato: Farmacêutico MARCOS ROBERTO DE MENDONÇA PELLICIARI.}

Título da dissertação: "A Liderança do docente como elo integrador no processo ensino-aprendizagem baseado em problemas (problem-based learning) em ambientes híbridos na engenharia".

Data da defesa: 11/04/2013

Comissão Julgađora:

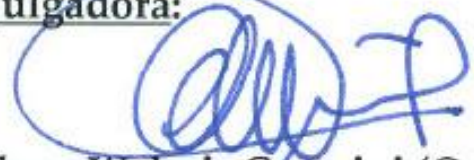

Prof. Dr. Edson Walmir Cazarini (Orientador)

(Escola de Engenharia de São Carlos/EESC)

Prof. Dr.Mateus decilio Gerolamo

(Escola de Engemharia de São Carlos/EESC)

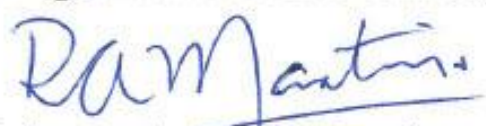

Prof. Dr. Roberto Antonio Martins

(Universidade Federal de São Carlos/UFSCar)

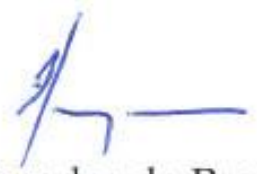

Coordenador do Programa de Pós-Graduação em Engenharia de Produção:

Prof. Titular Henrique Rozenfeld

Presidente da Comissão de Pós-Graduação:

Prof. Titular Denis Vinicius Coury

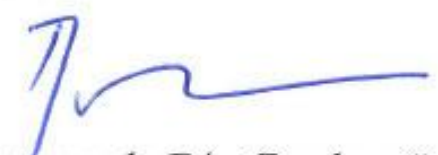

Resultado:

Aprovado

APREVADD

APROVADO 


\section{DEDICATÓRIA}

A todos que me acompanharam nessa jornada regada a desafios físicos, mentais e espirituais, tanto no plano fenomênico como no das partículas quânticas, vivendo, pois, minha alma uma hora envolta na positividade da oração dos que me amam e outrora na adversidade dos pensamentos negativos dos que interpelavam meu senso de certeza como uma alienação infundada, mas em todo momento conectado ao Ser Criador, que no final mostrou-me, e aos que em mim acreditaram, que a mudança advinda da constância de caráter e da firmeza de propósito gera a energia necessária para a transformação que desejamos ver no mundo, sendo no meu caso a contribuição para a sociedade feita por esta pesquisa para com os processos de ensino e aprendizagem por meio da necessidade da justificação do Docente como Líder em sala de aula, como fonte transformadora da sociedade, das organizações de ensino à sociedade em transformação, sendo a ponte que liga a ignorância ao saber. 


\section{AGRADECIMENTOS}

Ao Mestre com muito carinho (Prof. Dr. Edson Walmir Cazarini), que com a paciência dos grandes mostrou-me a humildade como o último degrau para a sabedoria, orientando nessa jornada um ser inquieto como eu sem em momento algum questionar meus pensamentos de forma a limitar as coisas nas quais eu acredito, mas instigando-me a ir além, sem perder a noção da realidade atual, e a futura. Professor Cazarini mostrou-me o alvo e ensinou-me a manusear o arco, sendo a flecha disparada a minha consciência vagando pelo espaço-tempo a cravar-se no centro da intenção que juntos propusemos.

Ao meu inestimável amigo Capitão Márcio Roberto Campos, sem o qual, pela motivação inicial, eu não teria apostado nessa jornada pelo caminho do saber. Amigo fiel, de incondicional afabilidade aos preceitos do que é correto e justo, um ser humano que emana a esperança que o mundo ainda tem chance de salvar-se frente às investidas dos injustos...

Aos meus familiares, que apenas pelo som de suas orações cotidianas fazem brotar em mim as sementes semeadas pela Sagrada Família de Jesus, Maria e José, cultivando em mim a espiritualidade necessária para atravessar os mais profundos abismos, as noites mais escuras, os desertos mais áridos, NUNCA perdendo a fé nos momentos mais difíceis, e nos momentos de bonança não se acomodando, ajudando assim a moldar o meu caráter em prol dos bons sentimentos... Agradeço também ao Sr. Aldeci Alves Cavalcanti pela inestimável amizade e ajuda enquanto meu patrão antes de eu adentrar ao mestrado, e à SAM, no decorrer dele...

À secretaria de pós-graduação e de graduação, a todos os funcionários do DEP e da Biblioteca da EESC, aos membros do Grupo DECIDIR, a todos os docente da Engenharia e aos queridos estudantes do curso de Engenharia de Produção da EESC-USP, pelo imenso carinho a mim dispensando em todos os momentos que eu tive o privilégio de com vocês interagir...

Aos membros das bancas avaliadoras, tanto da qualificação quanto da defesa, pela inestimável ajuda por intermédio da sabedoria de vida de cada um...

À CAPES, pelo apoio e incentivo financeiro para a conclusão do Mestrado...

E como os últimos sempre serão os primeiros, a DEUS, meu começo e meu fim, e após o fim, meu recomeço... 


\section{RESUMO}

PELLICIARI, M.R.M (2013). A liderança do docente como elo integrador no processo ensinoaprendizagem baseado em problemas (Problem-based learning) em ambientes híbridos na engenharia. 225f. Dissertação (Mestrado) - Escola de Engenharia de São Carlos, Universidade de São Paulo, São Carlos, 2013.

Muitas instituições de ensino superior (IES) buscam novas formas de aperfeiçoarem o processo ensino-aprendizagem visando adequarem as aulas tradicionais às tecnologias emergentes advindas da Web 2.0, como as mídias sociais. Nesse processo de reinvenção, o docente deve capacitar-se a ministrar aulas não apenas com o intuito de disseminar conhecimentos tácitos e explícitos, mas também de liderar os estudantes na sala de aula presencial e nos ambientes virtuais de aprendizagem, conduzindo-os a superarem suas expectativas quanto ao aprendizado. Analisando perfis de liderança existentes, a presente dissertação, focada em um Estudo de Caso, busca identificar qual o perfil ideal de liderança do docente em ambientes híbridos, utilizando-se para tal do Índice de Satisfação de Grupo, análise de gráficos e do discurso dos estudantes. O método de ensino adotado pelo docente foi o PBL (Problem Based Learning), dando-se ênfase ao desenvolvimento do pensamento critico. A pesquisa realizou-se junto a disciplinas do Departamento de Engenharia de Produção da EESC-USP, onde estudantes de graduação e pós-graduação foram desafiados pelo método PBL a pensarem de forma crítica na construção do próprio conhecimento. Os resultados obtidos por meio de questionários aplicados ao final dos semestres de 2011 e 2012 mostram que a liderança Laissez-faire não é indicada na fase de implantação do PBL, necessitando maior interferência do docente para a quebra do paradigma entre o modelo de ensino tradicional e o novo. Conclui-se que a conexão entre o processo ensino-aprendizagem tradicional e o novo possa ser feita por meio da liderança situacional, alternando a liderança transformacional e a transacional de acordo com o contexto, excluindo-se a Laissez-faire.

Palavras-chave: PBL. Processo ensino-aprendizagem. Liderança situacional. Liderança transformacional. Liderança transacional. Laissez-faire. Ambientes híbridos de aprendizagem. Sistemas complexos adaptativos. 


\begin{abstract}
PELLICIARI, M .R. M (2013). The teacher leadership and the Problem-based learning (PBL): an inseparable link in hybrid learning environments in engineering. 225f. Dissertação (Mestrado) Escola de Engenharia de São Carlos, Universidade de São Paulo, São Carlos, 2013.

Many institutions have developed new ways to improve the teaching-learning process, trying to adequate the classes to the emerging new technologies based on Web 2.0, as in the case of social media. In this re-inventing process teachers must have the leadership skills both in classrooms and virtual learning environments, allowing the students to overcome their expectations of the learning process. This dissertation is focused on a case study that seeks to identify what is the ideal leadership profile into hybrid environments, using a group satisfaction index, graphical analysis and student speeching skills. The teaching methodology used by the teacher was the PBL (Problem-based learning) that emphasizes the critical mindset. The research was carried out during the disciplines into the Manufacturing Engineering graduation and post-graduation program of Universidade de São Paulo (USP) EESC department. The students were challenged by the PBL methodology to think about the best way to build their own know how. The data obtained with the application of questionaries in the 2011 and 2012 semesters showed that the "Laissez-Faire" leadership is not recommended during the PBL methodology implementation, requiring more interferences and attention from the teacher to break the paradigm of the traditional teaching models. The conclusion is that the connection between the traditional and the new teaching-learning processes can be built using situational leadership, alternating between transformational leadership and transactional models, contextually, excluding the Laissez-faire.
\end{abstract}

Keywords: PBL. Teaching-learning process. Situational leadership Transformational leadership. Transactional Leadership. Laissez-faire. Hybrid learning environments. Complex adaptive systems. 


\section{LISTA DE FIGURAS}

Figuras

Pág.

Figura 1: Modelo do ciclo da gestão do conhecimento

Figura 2: Teoria Comportamental - Principais competências para uma liderança eficiente

Figura 3: Comparação do processo de aprendizagem entre inexperientes e especialistas

Figura 4: Estilos e Estratégias segundo Grupo APRENDER - EESC - USP Engenharia de Produção

Figura 5: Análise do índice de satisfação de grupo em relação às tarefas em si, como rotina e motivação

Figura 6: Análise do índice de satisfação de grupo quanto ao benefício do trabalho 100 desenvolvido

Figura 7: Análise do índice de satisfação de grupo em relação ao relacionamento interpessoal

Figura 8: Análise do índice de satisfação de grupo em relação ao trabalho em equipe

Figura 9: Análise do índice de satisfação de grupo em relação ao ambiente de trabalho

Figura 10: Análise do índice de satisfação de grupo comparado a outros grupos em sala

Figura 11: Análise do índice de satisfação de grupo em relação as condições de trabalho

106

Figura 12: Análise do índice de satisfação de grupo em relação aos aspectos sociais do trabalho em equipe

Figura 13: Análise do índice de satisfação de grupo em relação à motivação em se trabalhar em equipe

Figura 14: Análise do índice de satisfação de grupo em relação ao nível de reconhecimento e recompensa por parte do docente

Figura 15: Análise do índice de satisfação de grupo em relação à motivação para com os desafios apresentados pelo docente

Figura 16: Análise do índice de satisfação de grupo em relação aos fatores motivacionais intrínsecos ao grupo no percorrer dos desafios

Figura 17: Análise do perfil de liderança do docente relacionado ao estilo Laissez-faire

Figura 18: Análise do perfil de liderança do docente relacionado ao estilo 
Figura 19: Análise do perfil de liderança do docente relacionado ao estilo

Transformacional pertinente à dimensão da motivação

Figura 20: Análise do perfil de liderança do docente relacionado ao estilo

Transformacional pertinente à dimensão do estímulo intelectual

Figura 21: Análise do perfil de liderança do docente relacionado ao estilo

Transformacional pertinente à dimensão da ajuda individualizada

Figura 22 - Análise do perfil de liderança do docente relacionado ao estilo Transacional pertinente ao rigor das cobranças para com os estudantes

Figura 23: Análise do perfil de liderança do docente relacionado ao estilo Transacional pertinente à dimensão gerenciamento por Exceção Passiva

Figura 24: Análise do perfil de liderança do docente relacionado ao estilo Transacional pertinente à dimensão gerenciamento por Exceção Passiva

Figura 25: Grau de motivação dos estudantes de pós-graduação em 2011 antes e depois de trabalharem no Wiggio

Figura 26: Ferramentas mais utilizadas no Wiggio em 2011

Figura 27: Características de liderança a serem incorporadas pelo docente em um ambiente virtual de colaboração

Figura 28: Ranking das percepções dos estudantes de Pós-graduação no final do semestre de 2011

Figura 29: Aspectos positivos, negativos, dificuldades e sugestões em relação ao Wiggio

Figura 30: Outras mídias sociais e recursos utilizados durante o semestre fora do

Figura 32: Comparação da motivação gerada utilizando-se o Moodle quando

confrontado ao Google+ no trabalho em equipe no ano de 2011

Figura 33: Análise da utilização do Google+ e a percepção do estudante em relação a um perfil punitivo do docente no ano 2011

Figura 34: Comparação entre o índice de motivação gerado entre o Facebook e o Google+ no trabalho em equipe no ano de 2011

Figura 35: Análise do índice de complexidade do Google+ para o trabalho em equipe no ano de 2011

Figura 36: Análise do índice de motivação ao se trabalhar com o Moodle no ano de $2011 \quad 175$

Figura 37: Análise da utilização do Facebook no Ano de 2012

Figura 38: Comparação da motivação gerada utilizando-se o Moodle quando 
Figura 39: Análise da utilização do Facebook e a percepção do estudante em relação a um perfil punitivo do docente no ano 2012

Figura 40: Comparação entre o índice de motivação gerado entre o Facebook e o Google+ no trabalho em equipe no ano de 2012

Figura 41: Análise do índice de complexidade do Google+ para o trabalho em equipe no 186 ano de 2012

Figura 42: Análise do índice de motivação ao se trabalhar com o Moodle no ano de 2012 


\section{LISTA DE SIGLAS}

PBL Problem-based learning (Aprendizado Baseado em Problemas)

IES Instituição de Ensino Superior

TIC Tecnologia da Informação e Comunicação

BTCO Breve Teste de Comportamento Online

WWW World Wide Web (Rede de Alcance Mundial)

WBL Web-based learning (Aprendizado baseado na Rede)

JCR Journal Citation Reports (Jornal de Citações de Relatórios)

CAPES Coordenação de Aperfeiçoamento de Pessoal de Nível Superior 


\section{SUMÁRIO}

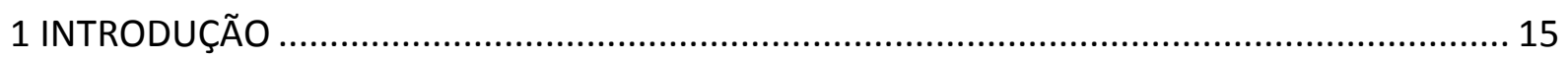

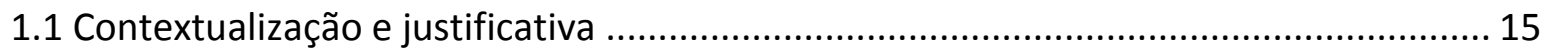

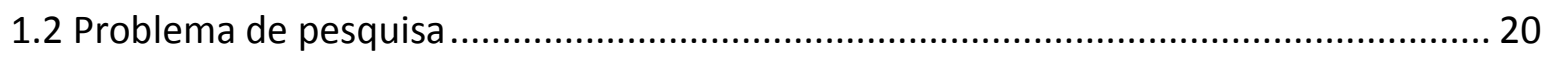

1.3 Declaração do objetivo de pesquisa .......................................................................... 23

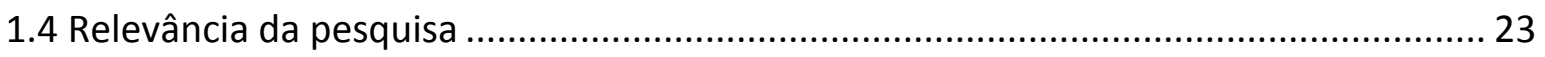

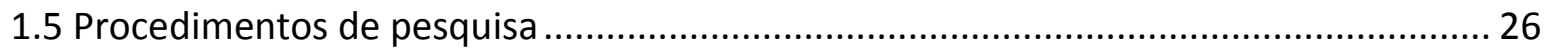

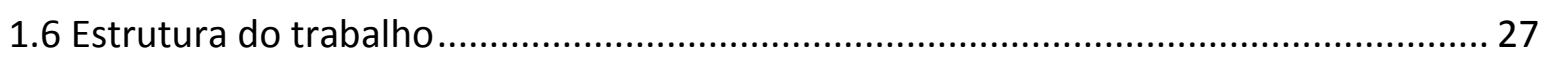

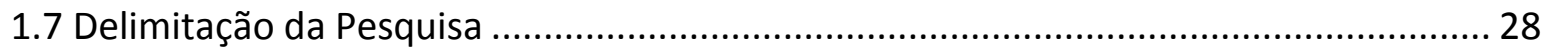

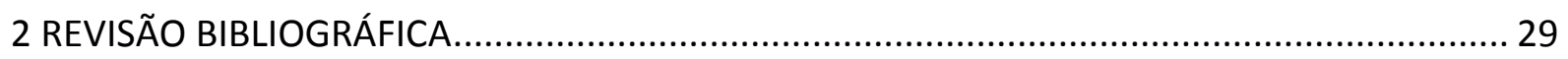

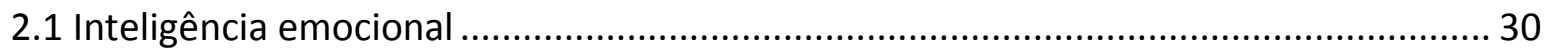

2.2 Identificando contextos e lidando com o conhecimento necessário ao líder................ 32

2.3 Sistemas Complexos Adaptativos e sua atuação nos contextos organizacionais, como o gerenciamento de equipes ..................................................................................... 40

2.4 Teorias da Liderança e novas abordagens sobre o líder............................................. 43

2.4.1 Teoria do Grande Homem ................................................................................ 44

2.4.2 Teoria dos Traços ......................................................................................... 45

2.4.3 Teoria da Liderança Espiritual......................................................................... 48

2.4.4 Teoria Comportamental.................................................................................. 49

2.4.5 Teoria da Liderança Situacional .................................................................... 53

2.4.6 Teoria da Liderança Complexa.......................................................................... 54

2.4.7 Teoria da Liderança Path Goal .............................................................................. 56

2.4.8 Teoria da Liderança Carismática ......................................................................... 57

2.4.9 Teoria da Liderança Transacional ....................................................................... 58

2.4.10 Teoria da Liderança Transformacional ................................................................. 59

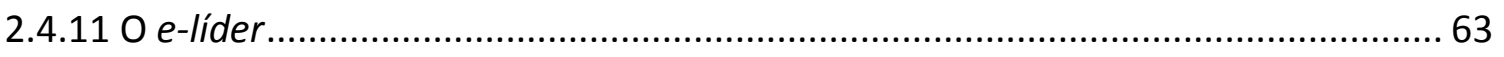

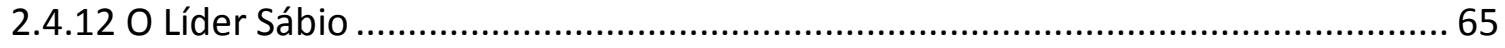

2.5 Liderança, Motivação e Princípios de Aprendizagem ................................................... 67 
2.6 Mídias Sociais e o Suporte ao trabalho colaborativo

2.7 O PBL no processo ensino-aprendizagem e a incorporação dos ambientes híbridos... 81

Síntese dos temas tratados. 88

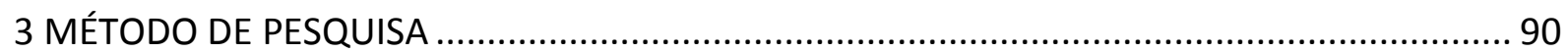

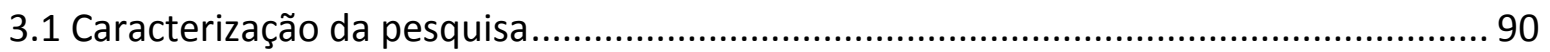

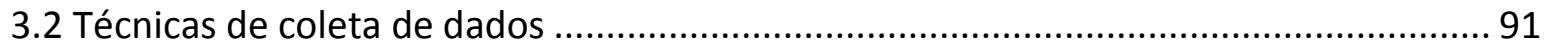

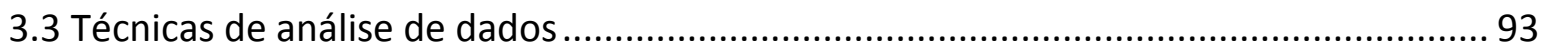

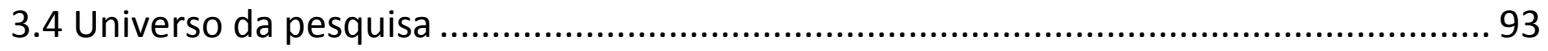

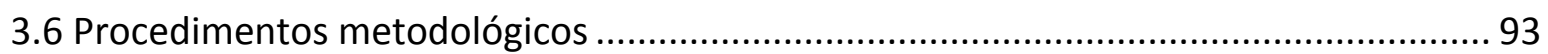

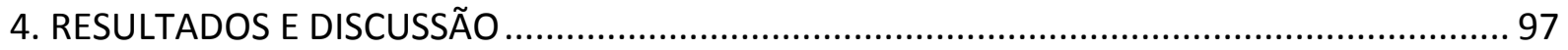

4.1 Análise do Índice de Satisfação do Grupo................................................................... 97

4.1.1 Itens de análise para obtenção do Índice de Satisfação do Grupo ........................ 98

4.2 Identificação do estilo de liderança do docente.

4.3 Percepção dos estudantes em relação às mídias sociais utilizadas nos anos de 2011 e 2012 e influências da liderança do docente na condução das disciplinas ministradas com o

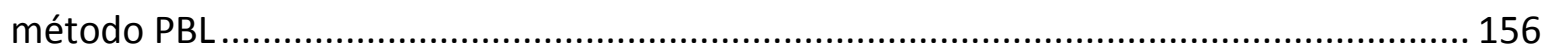

Análise da utilização do Wiggio em 2011 por estudantes da Pós-graduação ................ 156

Análise da utilização das mídias sociais em 2011 por estudantes do 20 ano, 4음 ano e Pós-graduação com foco no Moodle e Google+............................................................ 165

Análise da utilização das mídias sociais em 2012 por estudantes do $2^{\circ}$ ano, 4음 ano e Pós-graduação com ênfase no Moodle e Facebook. .................................................... 177

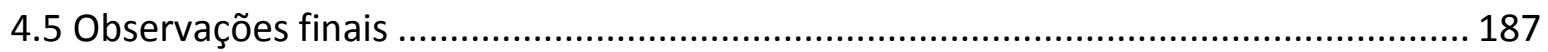

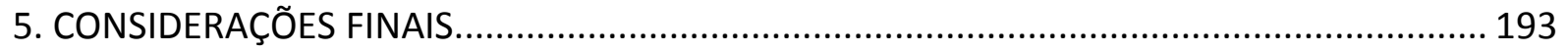

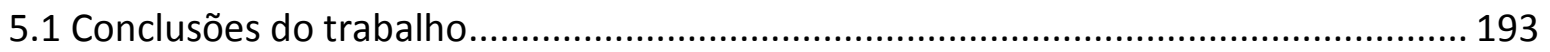

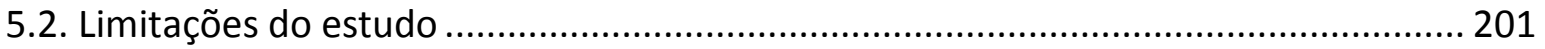

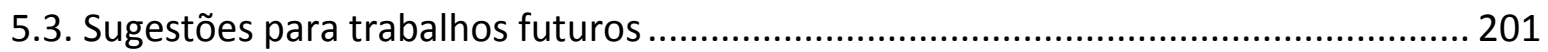

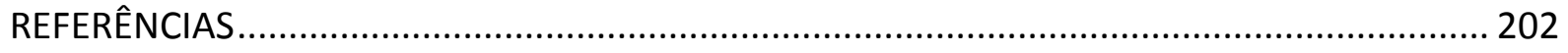

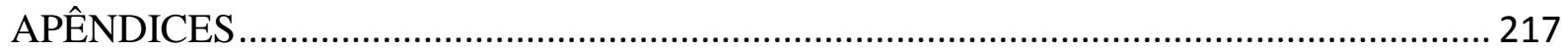

Apêndice 1 - Análise do Índice de Satisfação de Grupo (MASON; GRIFFIN, 2002),

Questão 1, Sub-questões de 1.2 a 1.12 ...................................................................... 218 
Apêndice 2 - Percepção individual em relação ao docente da disciplina, Sub-questões de 2.1 a 2.8

Apêndice 3 - Percepção individual em relação aos ambientes virtuais de colaboração utilizados, Sub-questões de 3.1 a 3.6 - Ano 2011

Apêndice 4 - Percepção individual em relação aos ambientes virtuais de colaboração utilizados, Sub-questões de 3.1 a 3.6 - Ano 2012

Apêndice 5 - Outras mídias sociais utilizadas durante o semestre e espaço para sugestões e críticas

Apêndice 6 - Uso do Google+ e outros serviços Google por estudantes em três disciplinas do $2^{\circ}$ semestre de 2011 do curso de Engenharia de Produção.

Apêndice 7 - Uso do Google+ e outros serviços Google por estudantes em três disciplinas do $2^{\circ}$ semestre de 2011 do curso de Engenharia de Produção - Grupos com melhores avaliações.

Apêndice 8 - Uso do Google+ e outros serviços Google por estudantes em três disciplinas do $2^{\circ}$ semestre de 2011 do curso de Engenharia de Produção - Grupos com piores avaliações 


\section{INTRODUÇÃO}

Subdividida em Contextualização e justificativa; Problema de pesquisa; Declaração do objetivo de pesquisa; Relevância da pesquisa; Procedimentos de pesquisa; Estrutura do trabalho e Delimitação da Pesquisa, visa de uma forma clara nortear o pesquisador, assim como os leitores, pelos processos inerentes à elaboração desta pesquisa científica, estruturada pelos requisitos técnicos das normas vigentes, fornecendo informações sobre a importância da pesquisa no meio acadêmico, assim como sua contribuição para com a sociedade.

\subsection{Contextualização e justificativa}

Nesses tempos observa-se uma força emergente que aumenta rumo a uma mudança social e organizacional global. Ultrapassando o físico, caminha em paralelo com redes virtuais de relacionamento advindas da evolução tecnológica, onde viver em comunidade deixou de ser algo exclusivamente táctil. Moxley (2000), desde o início deste século, afirma que a internet fomenta as principais forças mediadoras desse fenômeno, devido à velocidade das mudanças que dela derivam. No entrever desses eventos, nos vem uma chamada para uma liderança mais holística, que agregue os quatro campos principais que determinam o âmago da existência humana, o corpo (físico), mente (raciocínio lógico), coração (anseios, emoções) e espírito (MOXLEY, 2000). Responder a estas forças vai exigir uma grande transformação organizacional para um paradigma de aprendizagem que é radicalmente diferente do tradicional, apontada por Medrano (2010) como 
centralizada, padronizada e formalizada em seus modelos organizacionais burocráticos baseados no medo e no temor, paradigma dominante nas organizações desde o início da era industrial.

A união do software com o hardware, favorecendo o despertar da internet, mudou as estradas que percorremos em busca de interações sociais e aquisição de conhecimentos. O que não mudou em grande escala são os sentimentos dos humanos, criadores e usuários dessa nova tecnologia. Em termos de colaboração, muitas das vivências em comunidades tradicionais migraram para o mundo virtual acrescidas de uma sensação de liberdade que se mal gerenciada pode criar reveses quando se trabalha nesses ambientes, o que nos faz ter de atentar-nos com maior rigor ao grau de complexidade dos sistemas nos quais estamos interagindo como seres humanos e agentes integradores, complexidades estas discutidas pela Teoria dos Sistemas Complexos (WEAVER, 1948).

Em ambientes híbridos de aprendizagem, que combinam as tradicionais instruções Face a Face com tecnologias advindas da Internet, com potencial de fundir o melhor destas experiências (SWENSON; EVANS, 2003) a figura do líder emerge como fonte de observação das atitudes de seus colaboradores seguida de orientação pontual. Como exemplo da importância do líder, em testes efetuados online, denominados "BTCO: Breve Teste de Comportamento Online", Johnson (2007) observou comportamentos distintos do presencial em indivíduos inseridos em ambientes virtuais. A análise se esses comportamentos são adquiridos ou acompanham componentes psicológicos já presentes nos indivíduos pode nortear a delegação de funções em uma disciplina onde os estudantes atuam não apenas no espaço físico das salas de aula, mas também nos ambientes virtuais (LUTHANS; AVOLIO, 2003; RECUPERO, 2010), uma vez que, de acordo com o comportamento 
de determinados indivíduos nestes ambientes, é possível identificar sintomas de distúrbios psicológicos e traços de personalidade antes não observáveis presencialmente, como "crises maníacas, fobia social, depressão, introspecção, falhas de julgamentos e atitudes obsessivas e impulsivas" (RECUPERO, 2010, p.3).

Com essas informações podemos entender que estudantes inseridos em um ambiente presencial, como a sala de aula tradicional, e em ambientes virtuais de colaboração, com o suporte das mídias sociais, podem estar produzindo aquém de suas capacidades, acarretando perda de oportunidades de aprendizagem. Se o líder (docente ou tutor) não possuir a competência para identificar traços de comportamentos em seus estudantes, uma disciplina pode ser ministrada em vão (KARK; SHAMIR, 2003). É necessário aprender a aprender, tanto observando nosso comportamento, quanto ao do estudante, e identificar a visão que estamos transmitindo para a pessoa que nos observa (OWEN et al., 2006). Para aprender, primeiro é necessário aceitar as coisas que não sabemos. É difícil identificar nos modelos atuais de ensino, docentes empenhados em transmitir mais conhecimentos do que informações aos estudantes, ou seja, não se atentam o suficiente ao desafio de transformar seus conhecimentos tácitos em conhecimento tácito no estudante por meio do processo de socialização e também seus conhecimentos explícitos em conhecimentos tácitos nos mesmos por meio do processo de internalização, para que esses conhecimentos presentes na mente do docente tornem-se uma crença verdadeira e justificada na mente dos estudantes (NONAKA; TAKEUCHI, 1995).

Uma vez identificado que processos psicológicos podem também emergir em ambientes virtuais de colaboração, cabe ao líder atentar-se ao comportamento de seus colaboradores e atuar de forma holística no gerenciamento de sua equipe, tornando-se fonte de confiança, comprometimento e confidências que alavanquem o 
moral do time (DIRKS; FERRIN, 2002), características estas presentes na teoria da liderança transformacional, por exemplo (AVOLIO; KAHAI, 2002).

Continuando, é observado nesses tempos, no Brasil, que muitos engenheiros estão sendo contratados de outros países, por empresas de várias áreas, para gerirem empreendimentos. Esse fato indica que poucos são os profissionais formados no Brasil capazes de competir com gestores com visões sistêmicas advindas de universidades globais, como Harvard e Caltech. Nota-se uma lacuna em competências de liderança em profissionais brasileiros recém-graduados em engenharia, o que os remete a desempenharem, em muitos casos, o papel de profissionais de nível técnico. Para formar líderes, os docentes necessitam dominar não somente as tarefas cotidianas, mas também o comportamento humano, as qualidades que agregam valor aos relacionamentos interpessoais (CARUSO; SALOVEY, 2004). Atualmente a função do docente como líder deveria passar do papel, em grande parte, apenas de julgamento entre o certo e o errado para uma atuação mais sistêmica, como capacitador por meio do compartilhamento do conhecimento que dele deriva (BASS; AVOLIO, 1994). Atuando seguindo dimensões de teorias da liderança e adaptando-se aos seus pontos mais positivos de acordo com cada contexto de aula, o docente passa de expectador a maestro, transformando, por meio dos estudantes, a universidade em uma organização que aprende (SENGE, 1997), gerando coesão e comprometimento (ZACCARO; BURKE, 1998), por meio do processo de aprendizagem pelo compartilhamento do conhecimento individual entre os membros de um grupo até que o mesmo seja assimilado e individualizado (VYGOTSKY'S, 1978).

Assim sendo, observamos que na era do conhecimento é pertinente às organizações estarem na vanguarda da tecnologia, monitorando o ambiente no qual 
estão inseridas, atentando-se eficazmente não só ao que vai fazer, mas também, implicitamente, ao que não vai fazer estrategicamente (ANCONA, 1999; PORTER, 1979). A evolução e inovação de uma universidade se mostra presente por meio do conhecimento que traz intrinsecamente em seus colaboradores e que, quando compartilhado em grupo e intermediado pela Tecnologia da Informação e Comunicação (TIC), pode facilitar processos de inovação (COHEN; PRUSAK, 2001). Nonaka (2007) identifica que é papel do líder trazer à tona o conhecimento intrínseco a cada membro de uma equipe, para que este seja externalizado e agregue valor a uma organização. No contexto de uma universidade, cabe ao docente, como líder, esse papel de externalizar o conhecimento latente nos estudantes, o que é validado por Polanyi (1966), que defende que o ser humano possui mais conhecimento do que a capacidade de externalizá-lo, ficando o mesmo latente e necessitado de um agente integrador para que se consolide. Deste modo, o entendimento do docente em relação a esse processo de retenção de conhecimento permite que seu estudante possa ser trabalhado de forma que ultrapasse o limite do habitual e alcance outros níveis de produtividade pela disseminação e transferência de conhecimentos. Para isso, um componente que agrega grande parte das competências de um líder pode atuar como diferencial competitivo: A Sabedoria (NONAKA; TAKEUCHI, 2011). O líder sábio possui uma visão global e identifica cada contexto de ação, e o contexto é fator de impacto no desempenho de equipes, como já observado pelos mesmos pesquisadores em outras oportunidades.

\footnotetext{
"As pessoas não recebem um novo conhecimento de forma passiva; elas o interpretam ativamente, adaptando-o às suas próprias situações e perspectivas. Assim, o que faz sentido em um determinado contexto pode mudar ou até mesmo perder o sentido quando comunicado a pessoas de contexto diferente. Resultado: há confusão contínua quando um novo
} 
conhecimento é difundido em uma organização, cabendo ao gerente direcionar essa confusão para a criação do conhecimento." (NONAKA, 1991, p. 99).

Transformar a sala de aula em um local onde haja estimulação e inspiração intelectual são aspectos de uma liderança transformacional (BASS; AVOLIO, 1994) que contribui para proliferação da ética entre os estudantes (BASS; STEIDLMEIER, 1999). Tendo uma classe de aula motivada, torna-se apenas uma questão de tempo a consolidação do aprendizado no estudante, e para que haja esta motivação, o domínio e utilização de dimensões das teorias de liderança mais consistentes se torna o alicerce para que os docentes universitários na engenharia atinjam seus objetivos didáticos e educacionais.

Aprender a aprender, enxergando o estudante de uma forma holística (WILSON, 1998), permite aos docentes transformarem-se em líderes do conhecimento não apenas em aulas presenciais, mas também nos emergentes Ambientes Virtuais de Colaboração, e quando utilizando-se dos dois, nos chamados ambientes híbridos advindos da evolução tecnológica. O desafio estende-se no momento que o trabalho em ambientes híbridos é desenvolvido tendo o Problembased learning (PBL) como método de aprendizagem pela elucidação de problemas.

\subsection{Problema de pesquisa}

No atual cenário brasileiro, engenheiros estão sendo contratados de outros países devido a um déficit de mão de obra qualificada. Alinhar a formação dos engenheiros brasileiros para estarem preparados para as demandas correntes necessita, entre outras ações sistêmicas, de uma mudança do paradigma tradicional 
de ensino e a incorporação da Tecnologia da Informação e Comunicação (TIC) no processo ensino-aprendizagem. Nesse contexto, motivar os estudantes de engenharia a aprenderem de uma forma diferente, que os capacitem frente aos problemas complexos que a sociedade brasileira necessita combater, torna-se emergencial, além de fornecer o know-how para que os mesmos possam trabalhar em equipes globais.

Para atingir tais metas, a liderança necessária do docente frente aos estudantes, para conduzi-los pelo processo, parece engessada pela passividade frente a estes, atuando mais como disseminador de conteúdos pré-formatados do que motivador em prol do fomento da criatividade necessária para um pensamento mais sistêmico.

No contexto de parte das Instituições de Ensino Superior (IES) no Brasil, facilitadores tecnológicos que podem fornecer suporte ao docente, para que este atue como líder no processo ensino-aprendizagem na integração e comunicação com os estudantes, acabam por serem subutilizados, como os ambientes virtuais de colaboração, as mídias sociais (entre elas as redes sociais) e os dispositivos eletrônicos móveis. Assim, o processo ensino-aprendizagem que se utiliza da tecnologia pela incorporação pelo docente dos tradicionais ambientes de ensino face a face e os ambientes virtuais de colaboração dão origem aos chamados ambientes híbridos de aprendizagem, que aparentam prover possibilidades maiores de um aprendizado consolidado nos estudantes.

Como a TIC está acessível em grande parte das IES, pela redução dos custos de aquisição e manutenção, esse link entre instruções ministradas face a face e nos ambientes virtuais pelo docente torna-se possível em grande parte destas. Com isso, a busca de melhores soluções para problemas que a sociedade enfrenta 
passa, então, pela formação de profissionais mais bem preparados, o que necessita da capacitação dos docentes em atuar neste ambiente híbrido de aprendizagem. Os docentes necessitam, para isso, de estratégias motivacionais para fomentar a motivação nos estudantes, para estes disporem-se a aprenderem neste novo cenário. Complementando, utilizar o aprendizado baseado em problemas (PBL) como método de ensino na busca de superar o paradigma tradicional, voltado a conteúdos pré-formatados, parece ser o caminho certo na busca deste diferencial motivador, no momento que pode permitir a formação de profissionais mais preparados para lidarem com problemas reais, em ambientes complexos. Para gerar a motivação necessária, o docente, atuando com perfis de liderança adequados a cada situação, pode ser o elo entre o paradigma atual de ensino e um novo paradigma, onde a tecnologia está incorporada e os estudantes passam a serem responsáveis pelo próprio aprendizado. Buscar capacitar o docente com competências de liderança que fomente coesão entre este e os estudantes, combatendo o paradigma tradicional que aponta certa distância e consequente desmotivação entre os mesmos, torna-se emergencial na fase de implantação do PBL em ambientes híbridos de aprendizagem, mas para isso é imprescindível analisar qual é a real influencia da liderança do docente nos estudantes, assim como verificar se a TIC agrega ou não valor ao processo.

Pergunta norteadora: Qual é a influência da liderança do docente na motivação dos estudantes na resolução de problemas reais de engenharia com uso de PBL em ambientes híbridos de aprendizagem apoiados pela tecnologia de informação e comunicação? 


\subsection{Declaração do objetivo de pesquisa}

Identificar o estilo de liderança do docente que motive os estudantes na resolução de problemas reais de engenharia com uso de PBL em ambientes híbridos de aprendizagem apoiados pela tecnologia de informação e comunicação.

Sub-objetivos:

1) Compreender as inter-relações contextuais provenientes dos sistemas complexos, no processo ensino-aprendizagem, nos ambientes híbridos de aprendizagem, na solução de problemas reais;

2) Verificar a importância da dimensão da tecnologia da informação e comunicação (TIC), como as mídias sociais, no processo ensino-aprendizagem.

\subsection{Relevância da pesquisa}

Desânimo, desmotivação, estresse e insegurança aparecem rotineiramente embutidos nos espaços ocupados pelos estudantes de engenharia (EBLE, 1988). É necessária uma mudança de paradigma cultural que acompanha grande parte das IES e suas estruturas organizacionais verticalizadas. Desenvolver a liderança e ampliar o campo de visão dos docentes pode combater esses problemas, revertendo em um aumento exponencial da qualidade do processo ensino-aprendizagem em disciplinas, sejam quais forem elas ou seus métodos de ensino. A autoconsciência dos gestores das IES dos ganhos em capacitar níveis estratégicos de sua organização, como os docentes, com competências de liderança, gera essa necessidade da quebra do paradigma tradicional (GRENIER; METES, 1995). Isso se observa não apenas presencialmente no dia a dia das organizações, mas também 
em comunidades virtuais e equipes globais de colaboração (AVOLIO; KAHAI, 2002), assim como nos ambientes híbridos.

Em relação ao papel do líder, a capacidade de se ter seguidores sem que para isso haja qualquer tipo de pressão moral objetiva ou subjetiva, mas sim uma firmeza de propósito em prol de uma ética transparente onde todos saem ganhando, pode ser considerada uma liderança transformacional (BASS; AVOLIO, 1994). Outros tipos de liderança surgem nas trincheiras departamentalizadas de organizações estruturadas verticalmente, ou não, onde subalternos são chefiados e não liderados, caso em que o termo liderança se perde (MACKENZIE; HOUSE, 1975). O chefe alcança metas, mas não alcança pessoas. O líder proativo alcança pelas pessoas as metas, ultrapassando as expectativas quanto ao resultado, uma vez que agrega um valor subjetivo em seus liderados, valor que se somará ao conhecimento prévio adquirido, descartando retrabalhos. O líder cria um continuum de um projeto já concluído (MACKENZIE; HOUSE, 1975), já grande parte dos chefes concluem um projeto com um ponto final e começam outro sem considerar o aprendizado consolidado nas pessoas, não fornecendo flexibilidade nem criatividade aos colaboradores para que a organização caminhe à frente na infindável estrada da evolução e inovação (CHOO; BONTIS, 2002). Continuando, o líder busca soluções proativas mesmo nos mais complexos ambientes. O chefe atua mais na supervisão e em muitos casos pode corromper e contaminar até mesmo ambientes propícios ao crescimento individual e de equipes, o que compromete a motivação dos colaboradores, tornando o ambiente reativo e repleto de retrabalhos, contrastando com os resultados advindos de uma liderança proativa.

Pesquisas advindas dos fomentadores das primeiras teorias da liderança, como Fleishman (1953) e House (1971) concluem que há um ponto em comum aos 
líderes, e que cabe à confiança interpessoal. Influenciar pessoas positivamente e em ambientes complexos é um dom que deveria ser observado desde a alta administração, que nem sempre considera essa variável como atraente devido a fatores culturais intraorganizacionais. É preciso que haja um alargamento da visão dos tomadores de decisão em referência a essa questão.

As universidades necessitam de líderes que fomentem a coesão da equipe e a busca por resultados que estejam alinhados com o planejamento das tarefas para manterem-se competitivas. Uma vez que a tecnologia está presente em todos os níveis, o fator humano é determinante. "Líderes podem e fazem nossos resultados surgirem e desempenham um papel fundamental nas consequências advindas da diversidade da equipe, seus processos e resultados" (KLEIN, 2011, p. 29).

O fator liderança contribui para a valorização de equipes em sua diversidade e apresenta consequências positivas no gerenciamento de conflitos e na eficácia das tarefas (KLEIN, 2011). Quando observamos que equipes são como sistemas complexos (WEAVER, 1948), as percepções do líder em relação às peculiaridades individuais evitam que surjam ambientes adversos. É necessário que o docente, enquanto líder, atente-se à diversidade de conhecimentos relacionados às tarefas, competências e habilidades; de valores, crenças e atitudes; de personalidade e estilos cognitivos e comportamentais, de grupo e status organizacional (BELL; KOZLOWSKI, 2002), emergindo positivamente frente aos colaboradores pela sua característica transformadora (LUTHANS; AVOLIO, 2003), adaptando-se e utilizando-se de sua sabedoria natural (NONAKA; TAKEUCHI, 2011) para criar cenários proativos e bem receptivos pelos estudantes da engenharia. A relevância da pesquisa se mostra no momento que muitos são os resultados positivos observados em artigos publicados internacionalmente referentes aos benefícios da 
adoção de perfis de liderança pelos gestores em organizações de vários fins, mas praticamente inexistente quando o perfil de liderança analisado é o do docente universitário frente aos estudantes em ambientes híbridos, e os resultados advindos da utilização do PBL como método.

\subsection{Procedimentos de pesquisa}

A pesquisa bibliográfica foi desenvolvida utilizando-se o banco de dados ISI Web of Knowledge da Thomson Reuters e o gerenciamento bibliográfico pelo Endnote e Mendeley.

Em princípio foi realizado um levantamento bibliográfico com 500 (quinhentos) artigos com fator de impacto aferidos pelo Journal Citation Reports (JCR). Os artigos selecionados foram exportados para o Microsoft Office Excel, para criação de uma tabela dinâmica. Da análise de diferentes perfis gerados pela manipulação da tabela dinâmica, priorizou-se as publicações mais relevantes da área de pesquisa, os artigos JCR's com um maior nível de citações, preferencialmente de 10 anos até o momento presente, os autores principais, suas citações e quem era citado por eles.

Foi utilizado um software chamado Histcite para o mapeamento da evolução dos conhecimentos científicos dos autores mais relevantes, criando-se um mapa de citações.

O questionário aplicado ao final das disciplinas, com questões abertas e fechadas, foi validado pelos estudantes de pós-graduação da engenharia de produção da EESC-USP da disciplina de Sistemas de Apoio a Decisão de 2011, com o intuito de verificar inconsistências. Depois de validado, foi aplicado aos alunos da graduação, repetindo-se o processo em 2012, onde os resultados foram formatados, analisados e interpretados pelo pesquisador com o objetivo de captar as 
percepções dos estudantes em relação ao trabalho colaborativo nos ambientes híbridos de aprendizagem.

Observações e a análise do discurso dos estudantes foram feitas em relação a características de uma liderança que por ventura emergisse por parte do docente nos ambientes híbridos, tendo como finalidade criar um link para com o índice de satisfação do grupo.

\subsection{Estrutura do trabalho}

O presente trabalho está estruturado em cinco capítulos. O capitulo de numero um é denominado de "Introdução" e é subdividido em: Contextualização e justificativa; Problema de pesquisa; Declaração dos objetivos de pesquisa; Relevância da pesquisa; Procedimento de pesquisa; Estrutura do trabalho e Delimitação da Pesquisa. O segundo capítulo é dedicado à Revisão Bibliográfica, onde os temas da pesquisa são explorados no levantamento bibliográfico do estado da arte dos assuntos em pauta, como: Inteligência emocional; Identificação e maneiras de se lidar com o conhecimento necessário ao líder; Sistemas Complexos Adaptativos e sua atuação nos contextos organizacionais, como o gerenciamento de equipes; Teorias da Liderança e novas abordagens sobre o líder; Liderança, Motivação e Princípios de Aprendizagem; Mídias Sociais e o Suporte ao trabalho colaborativo; O PBL no processo ensino-aprendizagem e a incorporação dos ambientes híbridos. No terceiro capítulo é apresentada a metodologia de pesquisa, com a caracterização da mesma, as questões de pesquisa, as técnicas de coleta de dados, as técnicas de análise de dados, amostragem e procedimentos

metodológicos. No quarto capítulo são apresentados os resultados e no quinto 
capítulo as considerações finais, com a conclusão do trabalho, as limitações do mesmo e sugestões para trabalhos futuros.

\subsection{Delimitação da Pesquisa}

A delimitação indica a abrangência do estudo e estabelece os limites conceituais e a extensão do mesmo. Quanto maior a extensão conceitual, menor a compreensão dos temas, o que demanda acurácia na redação se muitos temas forem tratados (GIL, 2005). O fato de a pesquisa ter sido realizada apenas no Departamento de Engenharia de Produção da Escola de Engenharia de São Carlos da Universidade de São Paulo nos anos de 2011 e 2012 com estudantes das disciplinas de Sistemas de Informação e Sistemas de Apoio a Decisão da graduação e pós-graduação, tendo como docente apenas um professor doutor e participação deste pesquisador, permite que a descrição dos temas sejam melhor interpretados quando confrontados com os resultados, uma vez que os limites extensionais alocaram-se dentro do campus e nos ambientes virtuais, não expandindo-se para outros contextos.

Pesquisar a liderança do docente e analisar suas influencias no índice de satisfação de grupo utilizando-se de um método de ensino pouco compreendido pelos alunos (o PBL), e ainda em ambientes híbridos de aprendizagem, passa pela necessidade de uma revisão bibliográfica estruturada, por meio de uma visão sistêmica que permita criar uma relação entre os fatos analisados, não alargando os limites conceituais. Para esse fim, compreender assuntos como Inteligência Emocional, Sistemas Complexos, PBL e ambientes virtuais de colaboração torna-se imprescindível na medida em que os mesmos fornecem o suporte necessário para a 
interpretação dos eventos observados na aplicação do método de pesquisa. Elaborar o recorte final do estudo também demanda precisão, para que o objetico não se perca de vista. Em termos logísticos, a utilização de um questionário que demanda em média 10 minutos para o correto preenchimento se fez necessário no momento que sua aplicação é feita no final do semestre, quando os estudantes estão em época de prova, o que inviabiliza uma prática mais demorada, que poderia tirar o foco do estudante dos assuntos em pauta.

Assim, entende-se como delimitação temática, neste contexto descrito, identificar aspectos que traduzam, de uma forma coesa, as competências básicas para a liderança necessária de um docente que fomente alto grau de desempenho em equipes de colaboração em ambientes híbridos de aprendizagem, tendo o PBL como método e a TIC como suporte.

\section{REVISÃO BIBLIOGRÁFICA}

A revisão bibliográfica é entendida como uma apreciação crítica, minuciosa e extensa das publicações correntes em uma determinada área do conhecimento, tendo como objetivos averiguar se outros textos relacionados aos temas estudados já foram publicados, assim como avaliar a forma como esses assuntos foram tratados e analisados em estudos anteriores, permitindo ao pesquisador o conhecimento das variáveis do problema em questão (GIL, 2005). Assim sendo, a revisão bibliográfica que se segue foi elaborada com vistas a seguir esses critérios. 


\subsection{Inteligência emocional}

Herzberg et al (1959) faz uma conexão entre a satisfação no cumprimento de desafios organizacionais e a liderança, sugerindo que a insatisfação pode ter um impacto negativo no crucial relacionamento interpessoal líder-colaborador, pelo qual deve ser gerada a motivação necessária para realização de tarefas com maior qualidade. Torna-se necessário correlacionar aspectos de liderança com os da inteligência emocional, uma vez que estes se relacionam com a complexidade do mundo organizacional.

A inteligência emocional destaca-se como elo integrador entre o líder e liderados, uma vez que atua na motivação ou desmotivação de uns para com os outros. Como fator crítico de sucesso de um líder eficiente e eficaz, a inteligência emocional demanda um estudo mais aprofundado e uma necessidade mais acurada de entendimento. $\mathrm{Na}$ interpolação entre a inteligência emocional e os resultados advindos de seu correto entendimento, podemos verificar que muito do quesito motivação que dela advém está relacionado com a integridade moral dos agentes inseridos nos sistemas e a forma holística de se interpretar o universo ao redor (ALLAN, 1998; BRYMAN, 2004; BRYMAN, 2007a; BRYMAN, 2007b; GEORGE, 2000; HALL, 2002; HERZBERG; MAUNSER; SNYDERMAN, 1959; HESBURGH, 1988; HOUSE, 1977; IREY, 1987; KARK; SHAMIR; CHEN, 2003; KOTTER, 1996; KOUZES; POSNER, 1995; KOUZES; POSNER, 2004; LAABS, 1999; MOXLEY, 2000; MURRAY, 2002; NEWCOMBE; ASHKANASY, 2002; NONAKA; TAKEUCHI, 2011; PESCOSOLIDO, 2002; POUNDER, 2001; PURVANOVA; BONO, 2009; RANTZ, 2002; ROWLEY; SHERMAN, 2003), tendo como exemplos:

1) Engajamento e compreensão dos pontos fortes e limitações do seu "eu" e 
o do próximo, com clara visão de seus valores, crenças e atitudes

2) Integridade Pessoal, com firmeza de propósito, persistência e constância de caráter, com alto grau de manutenção e disseminação da esperança entre as pessoas e suas metas, adaptando-se a situações problema e atuando como exemplo de dedicação a um fim que pode se modificar no percorrer do percurso pela complexidade dos relacionamentos e acontecimentos da vida

3) Desenvolvimento e manutenção do senso crítico com um alto grau de integração verdadeira e confiança entre os membros da equipe, fomentando dessa forma uma crença mútua e o respeito entre os membros da equipe

4) Alta capacidade de coesão da equipe pela utilização de uma comunicação síncrona, honesta, com uma correta distribuição e delegação de tarefas e recursos, sem discriminação ou exercício do poder de forma inibitória

5) Apreciação e valorização das virtudes pessoais e grupais, com vistas a encorajar os membros das equipes em repercutirem com seus melhores potenciais

6) Alta capacidade de gerir conflitos com uso de uma visão holística não apenas do grupo, mas individual a cada membro

7) Não contentar-se com o óbvio, mas incutir nos membros da equipe a necessidade de criar novas soluções e, pela prática da criatividade, fornecer elementos que reinventem determinadas maneiras de se praticar a excelência organizacional

8) Altruísmo 
McElroy (2003) nos demonstra que gerir pessoas e seus mapas mentais inserido em um ambiente complexo, onde processos se inter-relacionam com atitudes individuais e de grupo por intermédio de ferramentas físicas ou mentais, necessita de um correto entendimento de como gerenciar o próprio conhecimento e o da equipe, membros ativos de uma organização que visa processos de aprendizagem e a assimilação dos entendimentos individuais e de grupo sobre as melhores práticas para o sucesso da mesma.

Identificar os elementos presentes no universo do conhecimento pode amparar o líder na medida que fornece ferramentas e metodologias para se alcançar o ótimo global pela correta interpretação do ambiente por meio da inteligência emocional.

\subsection{Identificando contextos e lidando com o conhecimento necessário ao líder}

Com o advento de uma nova economia, novas formas de se pensar foram necessárias para se obter um diferencial competitivo, levando a economia tradicional a ser vista como uma nova economia, pós-industrial (BELL, 1976). O conhecimento passa a ser um ativo das organizações (DUFOUR; STEANE, 2007) e a retenção e disponibilização do mesmo é proposto como meio para se alcançar novos patamares de evolução e inovação para as organizações por meio de seu capital humano e intelectual (GRANT, 2002).

Nesse cenário, o conhecimento passa a ser visto como um novo fator de produção e vantagem competitiva (DRUCKER, 1993), que pelo fato de ser um bem mais intangível que tangível, gera maiores índices de valorização ao colaborador 
(GRANT, 2002), que passa a ter maior reconhecimento profissional no momento em que passa de um cumpridor de funções (funcionário) a um potencial gestor de novos empreendimentos independente de seu nível hierárquico (DRUCKER, 1993).

Boisot $(1998,2002)$ diz que desde as revoluções científicas do século XVII, o conhecimento dita a atividade humana. Para Snowden (2002), o conhecimento humano é profundamente contextual e Polanyi $(1958,1966)$ argumenta que só sabemos o que sabemos, quando precisamos sabê-lo. Desse modo, sendo o conhecimento humano profundamente contextual, tende a se concentrar na coisa contida, ao invés do recipiente (SNOWDEN, 2002).

Micro estratégias advindas do entendimento da filosofia por detrás das teorias da liderança apregoam a distribuição da inteligência do grupo com fins para um ótimo global nas organizações, e maiores níveis de aprendizado são alcançados por indivíduos quando estas estratégias são trabalhadas dentro de um contexto de entendimento das novas ciências, como a ciência dos mundos complexos (MCKELVEY, 2011), onde o conhecimento humano é fundamental. Assim também acontece nas IES. Nesse ponto cabe uma pergunta: Como, então, motivar os estudantes a precisar saber o que precisam saber e no contexto em que estão inseridos? Como veremos mais adiante, no capítulo 2.4, sobre teorias da liderança e novas abordagens sobre o líder, uma das correntes que predominam no âmbito organizacional é a liderança situacional. Uma vez que o conhecimento humano é profundamente contextual, como nos afirma Snowden (2002), a liderança em diferentes contextos pode repercutir em diferentes níveis de motivação e aprendizado, sendo necessária uma adaptação do estilo de liderança de acordo com o contexto, expandindo a capacidade de se criar os resultados desejados 
coletivamente, aprendendo a aprender continuamente (SENGE, 1990). A importância do trabalho em equipe e a atuação do líder emergem nesse momento.

É vital, ainda, entendermos no que implica o conhecimento, partindo-se do pressuposto que dado, informação e conhecimento são três conceitos independentes que podem ser caracterizados como elementos ao longo de um continuum (BOISOT, 1998, 2002; LEONARD; SENSIPER, 2002; NONAKA, 2002; NONAKA; TAKEUCHI, 1995; TSOUKAS, 2005). Em resposta a isso, muitos autores abrangem diferentes definições para os termos: dado, informação e conhecimento. Boisot (1998) indica que essas definições estão sendo estabelecidas pelos profissionais e acadêmicos que trabalham no campo da psicologia, da história da sociologia à economia, o que demonstra a complexidade destas, explicando a relação entre estes conceitos: Conhecimentos baseiam-se na informação que é extraída a partir de dados. Já Leonard e Sensiper (2002) afirmam que o conhecimento é um subconjunto de informações. Nonaka e Takeuchi (1995) enxergam dados, informações e conhecimento como rearranjos ativos uns dos outros: Informação seria um fluxo de mensagens (ou significados), enquanto o conhecimento é criado por essa informação em cadeia, ancorada nas crenças e no empenho dos seus titulares, e nesse contexto identificam dois tipos de conhecimento, o conhecimento tácito e o explícito, validando a dimensão tácita do conhecimento humano já a muito pesquisada (POLANYI, 1958, 1966). Assim, O conhecimento explícito pode ser articulado e facilmente transmitido entre indivíduos e organizações e o conhecimento tácito (habilidades, know-how e conhecimento contextual) se manifesta apenas na sua aplicação, sendo que transferi-lo de um indivíduo para outro demanda investimento e paciência (NONAKA; TAKEUCHI, 1995). 
Nonaka e Takeuchi (1995) afirmam que o conhecimento tácito e o conhecimento explícito não são entidades completamente separadas, mas sim mutuamente complementares, interagindo um com o outro, realizando assim trocas nos processos criativos dos seres humanos, e argumentam que o conhecimento pode ser convertido por meio de quatro processos:

1. De conhecimento tácito em conhecimento tácito, chamado de Socialização, que é alicerçado na troca de experiências entre o mestre e - aprendiz por meio da observação, imitação e prática, sem necessariamente o emprego da linguagem, porém, fundamentalmente, há a necessidade de um vinculo emotivo entre os atores para o correto entendimento do contexto, em que o novo conhecimento é semeado, interpretado e assimilado

2. De conhecimento tácito em conhecimento explícito, denominado de Externalização, em que há um procedimento de articulação e codificação do conhecimento tácito em conceitos explícitos propagados na forma de metáforas, analogias, conceitos, hipóteses ou modelos, podendo ser armazenado na forma de alguma mídia para que o conhecimento a ser aprendido possa ser acessado facilmente pelo aprendiz por meio de manuais, documentos e procedimentos, além de elementos áudio-visuais e a arte humana

3. De conhecimento explícito em conhecimento explícito, definido por Combinação, um processo de conversão de conhecimento mediado pela ordenação de conceitos em um sistema de conhecimento, envolvendo 
mesclas diferentes de conhecimentos explícitos. Dá-se por meio da troca e combinação de conhecimentos contidos em documentos, assim como por meio de reuniões, aulas, troca de e-mails ou mensagens em redes sociais, telefonemas e outros processos intermediados pela TIC. Esse processo permite o acréscimo de novas informações na mente dos participantes e a consequente criação ou aquisição de novos conhecimentos, sendo muito utilizado no processo ensino-aprendizagem nas IES

4. De conhecimento explícito para conhecimento tácito, chamado de Internalização, um processo de incorporação do conhecimento explícito, presente em diversas fontes, em conhecimento tácito, na mente do aprendiz. A Internalização está profundamente relacionada ao aprendizado adquirido por tentativa e erro

Dentre os quatro processos de conversão do conhecimento, a externalização é a mais relevante no momento da concepção do conhecimento uma vez que cria novos julgamentos e formas de interpretação do mundo a partir de conhecimentos tácitos já consolidados, permitindo a expansão da mente criativa do ser humano e o vislumbre de novas soluções para problemas reais. Desse modo, cabe enfatilizar que a forma de se lidar com o conhecimento passa por etapas, como os processos de criação, aquisição, refinamento, armazenagem, transferência, compartilhamento e utilização (Figura 1). Frente aos diferentes conceitos entre dado, informação e conhecimento agora identificados, e devido às rápidas mudanças, as organizações passam a perceber uma "ausência de dados ou informações necessárias para fazerem um julgamento informado" (SPENDER, 2002, p. 154), o que pode prejudicar 
processos de tomada de decisões. Nas IES, as formas de se lidar com 0 conhecimento devem ser dominadas não apenas pelo docente, mas também pelos estudantes, para que um ótimo global seja alcançado. Em relação a esses processos de como se preparar para lidar com o conhecimento e suas nuances, Medrano (2010) nos apresenta uma adaptação do Modelo do Ciclo de Gestão do Conhecimento de King, Chung e Haney (2008), por ele analisado na Figura 1.

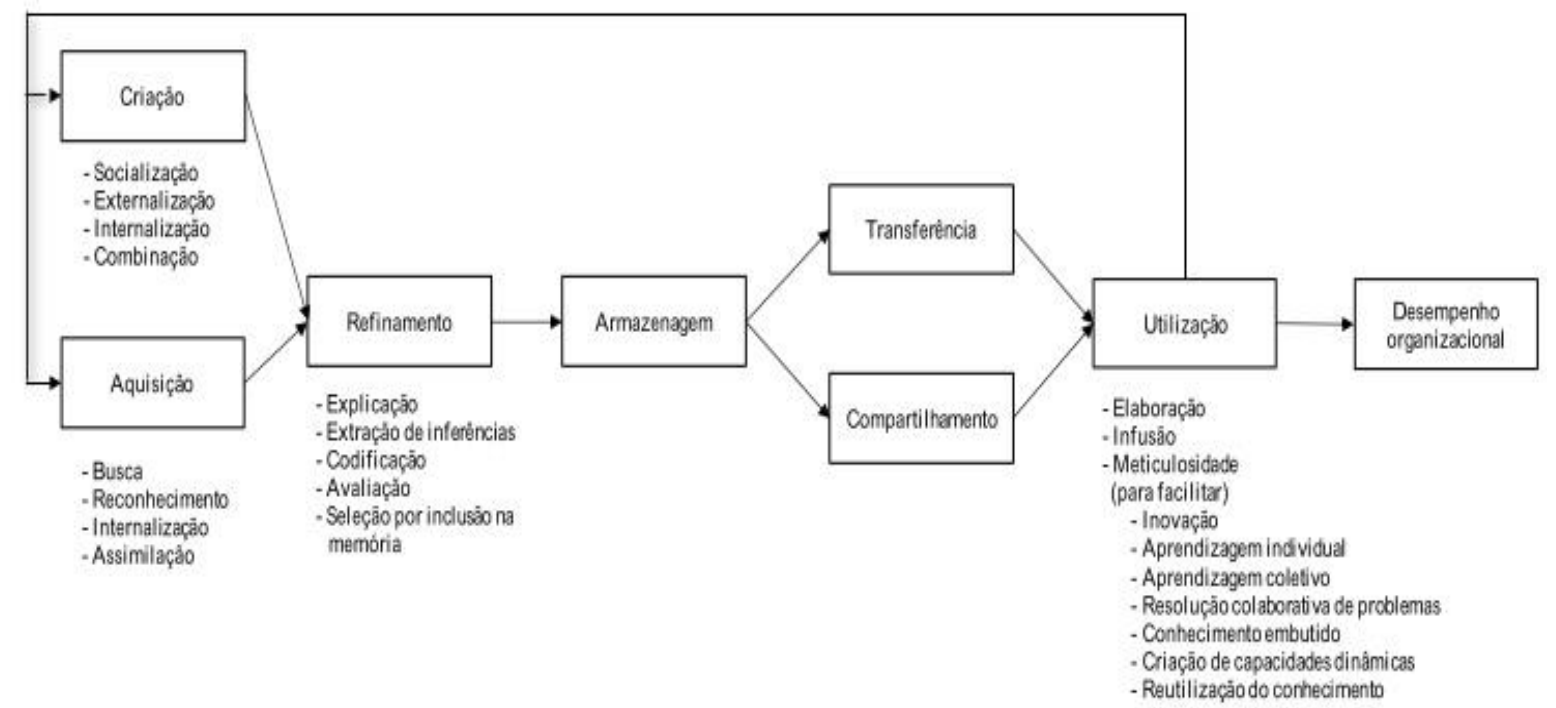

Figura 1 - Modelo do ciclo da gestão do conhecimento Fonte: Medrano (2010, pág. 47)

Medrano (2010) explica que os quatro pontos embaixo da fase da criação referem-se aos quatro modos de conversão do conhecimento propostos por Nonaka e Takeuchi (1995), estudados anteriormente. Destaca que, em contraste à criação do conhecimento interno, a aquisição envolve a busca, o reconhecimento e a assimilação do conhecimento potencialmente valioso, geralmente fora da organização. Enfatiza que após o conhecimento ser criado ou adquirido, deve ser preparado para ser ingressado dentro da memória da organização, para que possa haver a máxima reutilização ao longo prazo, evitando-se retrabalhos, sendo o refinamento do conhecimento o conjunto de processos e mecanismos que são 
utilizados para selecionar, filtrar, purificar e aperfeiçoar o conhecimento para sua inclusão em vários meios de armazenagem. Em relação ao conhecimento explícito, Medrano (2010) afirma ser necessário somente ser formatado, avaliado e selecionado, sendo utilizado ou reutilizado por meio da transferência e compartilhamento para outros membros da organização, resultando no desempenho organizacional. Prosseguindo, diz que a memória organizacional inclui o conhecimento armazenado na mente dos membros da organização, além do conhecimento mantido em repositórios eletrônicos ou físicos, que foram adquiridos e mantidos por grupos ou equipes e que estão embutidos nos relacionamentos internos e externos, nos processos do negócio, nos produtos e serviços. As mídias sociais passam a aparecer com maior ênfase nesses cenários no momento que permitem a observação da evolução do conhecimento no tempo, por meio das interações interpessoais registradas nos ambientes virtuais.

Uma vez explorado o Ciclo de King faz-se necessário entender que existem alguns Fatores Críticos de Sucesso para se lidar com o conhecimento nas organizações são fundamentais e, se bem analisados e priorizados aqueles com maior influencia, facilita a compreensão de que barreiras intra-organizacionais podem interferir na trajetória para a excelência na gestão frente a um objetivo (WITTROCK, 1989).

Fatores Críticos de Sucesso, segundo Medrano (2010):

a) Estratégia para o conhecimento

b) Cultura organizacional voltada ao conhecimento

c) Estrutura organizacional

d) Equipe do Conhecimento / Líderes de conhecimento / Trabalhador do conhecimento

e) Ferramentas tecnológicas 
f) Ciclos estruturados para consolidação da estratégia

g) Métricas para mensuração dos resultados

Em relação ao ambiente em que estão inseridas as IES, podemos enfatizar que a Cultura e a Estrutura Organizacional se sobressaem no momento em que esse trabalho procura identificar, no docente inserido neste contexto, diferentes vertentes das Teorias de Liderança que melhor repercutam na condução do método PBL em ambientes híbridos de aprendizagem. Hislop (2005) afirma que os fatores humanos, sociais e culturais são tipicamente os principais determinantes do sucesso ou fracasso de iniciativas inovadoras, o que demanda do docente uma correta interpretação dos contextos por meio da inteligência emocional. Uma vez que o conhecimento organizacional é um processo cujo objetivo é melhorar o desenvolvimento da organização e da sociedade por meio de novas iniciativas (MCELROY, 2003), o PBL poderia ser conduzido nas IES de maneira que semeasse a motivação dos estudantes na busca do conhecimento, como agentes ativos e não passivos, frente aos processos inerentes ao desafio da mudança. Isso requer um novo movimento que vai além de simplesmente expor presencialmente informações ou colocar mais conhecimento em bases de dados para o de alavancar as muitas maneiras que o conhecimento pode ser convertido, interferindo positivamente no desempenho de equipes (PÉREZ LÓPEZ; MONTES PEÓN; VAZQUEZ ORDÁS, 2005). Não obstante, o docente, tendo o domínio das várias facetas da liderança, assim como os processos envolvidos para otimização do conhecimento nas organizações, pode vir a atuar de forma muito confortável dentro desse ambiente de mudança de paradigmas nas IES. 


\subsection{Sistemas Complexos Adaptativos e sua atuação nos contextos organizacionais, como o gerenciamento de equipes}

Podemos dizer que sistemas complexos é uma nova abordagem para a ciência que estuda como as relações entre as partes dão origem aos comportamentos coletivos de um sistema e como o sistema interage e faz relações com seu ambiente (HAYEK, 1952). Um pioneiro no campo, e inspirado por Karl Popper e Warren Weaver, Prémio Nobel da Economia e filósofo, Friedrich Hayek dedicou muito de seu trabalho, desde o início ao final do século 20, com o estudo de fenômenos complexos, não restringindo seu trabalho para economias humanas, mas para outros campos com o passar dos anos, como a psicologia, a biologia e a cibernética, validando Steven Strogatz em suas afirmações de que a cada década uma teoria grandiosa estaria em voga, tendo aspirações semelhantes, interrelacionando-se com o conhecimento já adquirido previamente. Na década de 1960, era muito enunciada a cibernética do matemático norte-americano Norbert Wiene, que se tornou proeminente alguns anos após a publicação de seu artigo Cibernética ou regulação e Comunicação no animal e na máquina, em 1948. Nos anos 70, o foco estava com a teoria da catástrofe do matemático francês René Thom, seguida nos anos 80 pela Teoria do Caos do matemático americano Edward Norton Lorenz e nos anos 90 pela Teoria da Complexidade validada em 1964 pelo matemático americano Warren Weaver (BRUCE, 2003; CALDWELL, 2003; GLEICK, 1987). Assim, o termo Sistemas Complexos emergiu com maior ênfase quando Lorenz (1963) descobre acidentalmente, por meio de seu trabalho em previsão do tempo em 1961, que pequenas mudanças nas condições iniciais produziam grandes alterações no resultado em longo prazo nas condições climáticas. Portanto, um sistema complexo é visto como qualquer sistema com um grande número de 
componentes que interagem, cuja atividade é não-linear e, normalmente, apresenta auto-organização sob pressões seletivas (ROCHA, 1999).

Em termos mais simples, a teoria da complexidade se afasta da linearidade, do ponto de vista mecanicista do mundo, em que apenas são vistas as causas e os seus efeitos. Ultimamente os pesquisadores tem se empenhado em procurar soluções para explicar fenômenos físicos e sociais em uma perspectiva do mundo como não linear e orgânico, caracterizado por incerteza e imprevisibilidade (PRIGOGINE, 1997; REGINE; LEWIN, 2000), assim como acontece em ambientes híbridos. Vale frisar que o uso do termo complexidade é frequentemente confundido com o termo complicado. O complexo é o oposto de independente, enquanto complicado é o oposto de simples (LISSACK; ROOS, 2000). Assim, a complexidade do sistema pode ser de uma das duas formas: a complexidade desorganizada e a complexidade organizada (WEAVER, 1948), emergindo nesse cenário o termo Sistema Complexo Adaptativo.

Sistema adaptativo complexo denota sistemas que têm alguns ou todos os seguintes atributos (JOHNSON, 2007):

- O número de peças (e os tipos de peças) no sistema e o número de relações entre as partes não é trivial - no entanto, não há regra geral para separar trivial de não trivial;

- O sistema tem memória ou inclui feedback

- O sistema pode se adaptar de acordo com a sua história ou feedback

- As relações entre o sistema e o seu ambiente não são triviais ou lineares

- O sistema pode ser influenciado por, ou pode adaptar-se ao seu ambiente

- O sistema é altamente sensível às condições iniciais 
Holland (2006) afirma que o termo sistemas complexos adaptativos, ou ciência da complexidade, é repetidas vezes usado para descrever o campo ainda fracamente estudado nas instituições de ensino e que vem evoluindo em torno do estudo de tais sistemas. Afirma também que a ciência da complexidade não é uma teoria única uma vez que engloba mais de um quadro teórico e é altamente interdisciplinar, buscando as respostas para algumas questões fundamentais sobre a vida, adaptabilidade e sistemas mutáveis. Exemplifica sistemas adaptativos complexos como o mercado de ações, sociedade de colônias de insetos (formigas, abelhas, entre outros), a biosfera e o ecossistema, o cérebro e o sistema imunológico, a célula e o embrião em desenvolvimento, as empresas de manufatura e qualquer grupo social humano baseado em um empreendimento cultural e sistema social, tais como partidos políticos ou comunidades. Em todas as áreas os princípios de emergência e auto-organização são muito importantes.

Uma vez visto que qualquer grupo social humano baseado em um empreendimento cultural e sistema social são denominados sistemas complexos adaptativos, pode-se criar uma conexão com grupos sociais inseridos nas IES, como estudantes e docentes, e teorias da liderança que podem dar suporte ao docente na condução dos estudantes por meio do PBL, sendo uma delas claramente espelhada na Teoria da Complexidade (BROWN; GIOIA, 2002; GRONN, 2002), sendo denominada Teoria da Liderança Complexa (MARION, 1999). Assim, Marion (1999) desenha na ciência da complexidade a teoria da liderança complexa, oferecendo uma nova perspectiva para liderança, considerando a liderança no âmbito da ideia de um sistema adaptativo complexo. Em tais sistemas, as relações não são primariamente definidas hierarquicamente, como estão em sistemas burocráticos, mas sim pelas interações entre os agentes heterogêneos e através de redes de 
agentes. Partindo desses pressupostos, a ação do líder pode repercutir positiva ou negativamente em longo prazo, o que remete a importância de sua inteligência emocional em processos de mudança, no caso das IES, na fase de implantação do PBL em ambientes híbridos.

Pelo observado na Teoria da Liderança Complexa, os Sistemas Complexos Adaptativos e a liderança estão interligados (STACEY, 2001) uma vez que a liderança nas organizações contemporâneas deve incluir a capacidade de antecipar, identificar e responder às ocasiões inerentes ao ambiente organizacional (PORTERO'GRADY; MALLOCH, 2003), adaptando-se a este contexto, como exemplo, na condução dos estudantes pelo docente pelos caminhos propostos pelo método de aula em ambientes híbridos de aprendizagem.

\subsection{Teorias da Liderança e novas abordagens sobre o líder}

Cabe uma investigação das principais teorias da liderança e dos mais recentes assuntos à respeito desse fenômeno para concatena-las ao contexto atual das IES, onde muito do processo ensino-aprendizagem, e a disseminação dos conhecimentos do docente, ocorrem de forma expositiva e sistemática, por meio de conteúdos pré-formatados, onde o pensamento crítico dos estudantes não é explorado com vistas a capacita-los como responsáveis pelo próprio aprendizado, como orienta o PBL.

Sendo as IES sistemas complexos que tem por objetivo prover ensino de nível superior, graduação, e pós-graduação, além de desenvolver pesquisas científicas, que visa como produto de seus processos no quesito educação, entre outros, egressos dotados de competências profissionais com conhecimentos para assumir responsabilidades tanto técnicas quanto gerenciais, necessitam como agentes integradores profissionais com visão sistêmica (BUARQUE, 1994). Para 
tantos desafios, a figura do docente como líder proativo emerge frente às dificuldades enfrentadas pelos estudantes durante os processos nos quais estão inseridos visando o aprendizado. $O$ docente como líder proativo, além de atuar como facilitador, pode romper a barreira do ensino tradicional, fornecendo aos estudantes a capacidade do pensamento critico necessário para enfrentarem os desafios vindouros. Importante também identificar nesse item alguns novos conceitos, de novas teorias que podem estar surgindo, mas que ainda não foram consolidadas, como a do líder sábio.

\subsubsection{Teoria do Grande Homem}

Baseada na crença que os líderes são pessoas excepcionais, nascidos com qualidades natas, destinados a liderar. $\mathrm{O}$ uso desse termo homem foi intencional desde que antigamente, na maior parte do século XX, a liderança era pensada com o conceito o qual primariamente remetia ao macho, militar e ocidental.

O dito popular "Os grandes líderes nascem, não são feitos" resume o princípio básico da Teoria do Grande Homem da liderança (STRAKER, 2012) que propõe que a aptidão de liderança é inata. De acordo com esta teoria, você é um líder nato ou

você não é. $O$ termo Grande Homem foi empregado porque, nos primórdios, a liderança foi pensada essencialmente como uma qualidade do sexo masculino, especialmente em termos de liderança militar.

A Teoria do Grande Homem tornou-se popular durante o século 19. A história que acompanha alguns dos líderes mais famosos do mundo, como Abraham Lincoln, Júlio César e Alexandre, o Grande, ajudaram a colaborar para uma noção de que os grandes líderes nascem e não são feitos. Parece como que se o homem certo para 0 trabalho certo nascesse quase que magicamente para assumir 0 
controle de uma situação e liderar um grupo de pessoas para a segurança ou sucesso.

O historiador Carlyle (1888) representou uma grande influência sobre essa teoria de liderança ao afirmar que naquela época os líderes eficazes eram aqueles dotados de inspiração divina e as qualidades certas, apontando que algumas das primeiras pesquisas sobre liderança observou pessoas que já eram líderes de sucesso. Estes indivíduos usualmente incluíam governantes da aristocracia que obtiveram sua posição por meio de primogenitura. $O$ fato de que as pessoas de um estatuto social menor tiveram menos oportunidades para praticar e alcançar cargos de liderança contribuiu para a ideia de que liderança é uma habilidade inerente (HIRSCH, 2002). Ainda hoje, muitas vezes as pessoas descrevem líderes proeminentes como tendo as características certas ou a correta personalidade para o cargo, o que implica que características inerentes são o que tornariam essas pessoas líderes eficazes.

Argumentos contrários à Teoria do Grande Homem da Liderança eram defendidas pelo sociólogo Herbert Spencer, que propunha que os líderes eram produtos da sociedade em que viviam. Spencer (1896), no estudo da sociologia, argumenta que deve-se admitir que a gênese de um grande homem depende da longa série de influências complexas que tem produzido a corrida em que ele aparece, e do estado social em que essa raça tem crescido lentamente, afirmando que antes que o homem possa refazer sua sociedade, sua sociedade deve fazê-lo.

\subsubsection{Teoria dos Traços}

A lista de traços ou qualidades associadas com a liderança existe em abundância e continua a ser difundida. Ela desenha virtualmente todos os adjetivos 
do dicionário que descreva algumas atitudes e atributos humanos positivos, desde a ambição ao entusiasmo de vida.

Em 1936, dois psicólogos pesquisaram todas as páginas de um dicionário inglês e encontraram 17,953 palavras que descreviam diferenças psicológicas, ou traços, entre as pessoas. Buscaram congruência entre elas e as embutiram em algumas dimensões. Na medida em que sugeriam que a personalidade tem um componente genético, o docente, por exemplo, nasceria com essas características, assim como atletas e artistas (ALLPORT; ODBERT, 1936). Um traço pode ser refletido como uma particularidade relativamente estável que faz com que os indivíduos se comportem de determinadas maneiras (BOEREE, 2006). Enquanto a maioria concorda que as pessoas podem ser descritas com base em traços de sua personalidade, os teóricos continuam a debater o número de traços básicos que compõem a personalidade humana (ALLPORT; ODBERT, 1936). William Butler Yeats, poeta Irlândes, defende que a educação não é o enchimento de um balde, mas a iluminação de um incêndio. Com base nessa afirmação, a capacitação do docente com os traços mais proativos ajudaria a tornar a sala de aula um lugar mais plausível, sendo o combustível para essa energia advinda de características de liderança neles já presentes (KELLY-GANGI; PATTERSON, 2001).

"No filme Sociedade dos Poetas Mortos, Robin Williams interpreta Mr. Keating, um docente muito carismático do ensino médio na Inglaterra (na verdade, Robin Williams interpreta a si mesmo, mostrando o que seria ter Robin Williams como um docente). Se poucos, ou algum de nós, poderia ser capacitado para ser tão dinâmico na sala de aula como Robin Williams, poderíamos ao menos nos beneficiar de formação em pedagogia, a arte e a ciência de ensinar" (KELLY-GANGI; PATTERSON, 2001, p. 3, tradução livre). 
Assim, a identificação e capacitação do docente em traços de liderança mais propícios a determinados contextos, utilizando-se para isso de características nele já presentes, o levaria além da pedagogia em si, transformando-o em disseminador da aptidão de liderar estudantes em ambientes híbridos de acordo com os estilos de aprendizagem que identificasse como características intrínsecas nos mesmos. Mais, identificar os traços de personalidade nos estudantes daria a oportunidade de trabalha-los com vistas a ajudar a formar novos líderes, fato emergencial no momento em que na engenharia estudantes se mostram com poucas aptidões de liderança pela cultura e estrutura organizacional embutida nos processos de ensinoaprendizagem advindos por anos com a metodologia usual, inflexível na maior parte dos momentos e pouco criativa (CHICKERING; GAMSON, 1987; DURNEY, 1973; IREY, 1987; WALES, 1976). As macro dimensões da Teoria dos Traços, também chamadas de "THE BIG FIVE" (EYSENCK, 1992) podem ser descritos como:

1. Extroversão: Entusiasmo; Assertividade; Pró-atividade; Emoções positivas; Busca por emoções fortes

2. Afabilidade: Confiança; Altruísmo; Observação; Moderação

3. Consciência: Competência; Ordem; Senso de dever

4. Neuroticismo: Ansiedade; Hostilidade; Depressão; Autoconhecimento; Impulsividade e Vulnerabilidade

5. Abertura: Valores; Ideais; Ações; Sentimentos; Fantasia

Algumas das críticas mais comuns quanto a teoria dos traços está no fato de que os traços são muitas vezes pobres preditores de comportamento (MCCRAE; COSTA, 1997). Enquanto um indivíduo pode ter alta pontuação nas avaliações de um traço específico, ele ou ela pode nem sempre se comportar dessa forma em cada situação específica (CATTELL, 1965), ainda mais quando utilizado os 
ambientes híbridos para ministrar aulas.

\subsubsection{Teoria da Liderança Espiritual}

Salienta que os ambientes organizacionais são muito complexos e exigem uma resposta rápida dos elementos neles presentes quando confrontados com problemas não estruturados. Como exemplo, podemos citar docentes interagindo com estudantes em ambientes híbridos de aprendizagem.

Moxley (2000) diz que organizações burocráticas eficazes do passado refletiram seus maiores valores em sociedades centralizadas, padronizadas e formalizadas. A motivação nesse ambiente de trabalho era por meio do medo e recompensas extrínsecas, como apenas as monetárias (DAFT; LENGEL, 1998) e, portanto, não poderia ser uma fonte de sobrevivência da motivação necessária para gerarem melhorias contínuas para a organização.

Assim, a teoria causal da liderança espiritual é desenvolvida dentro de um modelo de motivação intrínseca, que incorpora a visão, a esperança, a fé e o amor altruísta às teorias da espiritualidade no trabalho, e da sobrevivência espiritual, podendo ser também interpretada como processos advindos do líder para a manutenção do entusiasmo no colaborador, na vontade deste viver com ânimo e contribuir para a sociedade por meio do trabalho (MOXLEY, 2000).

Para as organizações, isso significa criar um sistema humanista conduzido com base na esperança, que pela liderança espiritual, engaja o colaborador pela fé em uma visão fundamentada na cultura, com valores do amor altruísta (FRY, 2003). Os líderes espirituais influenciam estrategicamente as organizações por meio da visão, valores e relacionamentos amistosos, e não por meio do medo, do poder legítimo e do controle (DAFT, 2001; DAFT; LENGEL, 1998; FERRIS, 1988; HALEY, 
1993). A liderança espiritual deve ser vista como um processo intrínseco de motivar as pessoas a sentirem-se partes ativas dos relacionamentos que conduzem ao sucesso do negócio, pela energização e conexão com o seu trabalho. É esta força espiritual que se traduz em sentimentos de sobrevivência nobres, atração pelo trabalho, diversão sadia e respeito para com as pessoas no ambiente de trabalho, em um empenhado e produtivo comportamento organizacional em prol do bem comum (COVEY, 1989, 1991). Com o uso dessa abordagem é possível que a organização mantenha-se competitiva e atue como fomentadora de melhorias no âmbito do altruísmo na sociedade do novo milênio (DALAI LAMA XIV, 1999).

\subsubsection{Teoria Comportamental}

A teoria comportamental concentra-se em que os líderes atualmente fazem, mais do que suas qualidades. Diferentes tipos de comportamento são observados e categorizados como estilos de liderança. Essa área tem fascinado gestores organizacionais. O modelo da grade gerencial (BLAKE; MOUTON, 1964) identifica inicialmente cinco estilos de liderança diferentes com base na preocupação com as pessoas e a preocupação com a produção, que são: Iniciativa; Investigação; Defesa; Tomada de decisão; Resolução de conflitos. Esse modelo, ainda muito estudado, foi acrescido de dois novos elementos em 1985, quando Resiliência e Análise foram incorporadas (BLAKE; MOUTON, 1985). Mckee e Carlson (1999) resumem a soma dessas competências necessárias para uma liderança eficiente, segundo a teoria comportamental, na Figura 2. 


\begin{tabular}{|l|l|}
\hline Descrição & \multicolumn{1}{|c|}{ Elemento } \\
\hline Iniciativa & Agir, dirigir e apoiar \\
\hline Investigação & $\begin{array}{l}\text { Questionar, pesquisar e verificar a } \\
\text { compreensão }\end{array}$ \\
\hline Defesa & $\begin{array}{l}\text { Expressando convicções e defendendo } \\
\text { ideias }\end{array}$ \\
\hline A tomada de decisão & $\begin{array}{l}\text { Avaliação dos recursos, escolhas e } \\
\text { consequências }\end{array}$ \\
\hline Resolução de conflitos & Enfrentar e resolver desacordos \\
\hline Resiliência & $\begin{array}{l}\text { Lidar com problemas, contratempos e } \\
\text { fracassos }\end{array}$ \\
\hline Análise & Entrega de objetivos e feedback sincero \\
\hline
\end{tabular}

Figura 2 - Teoria Comportamental - Principais competências para uma liderança eficiente

Fonte: MCkee e Carlson (1999)

Dentre os estilos comportamentais de liderança podemos enfatizar: O líder autoritário; O líder democrático e o Líder Laissez-faire (EAGLY; ENGEN; JOHANNESEN-SCHMIDT, 2003), que possuem os seguintes atributos:

\section{- O Líder Autoritário}

1) Toda política do trabalho determinada pelo líder

2) Atividades e passos técnicos ditados pela autoridade, um por vez, para que os passos futuros sejam incertos para os membros, e em grande medida, mediados pelo controle completo da situação

3) O líder usualmente dita os tarefas individuais e dos membros da equipe

4) O dominador é pontual nos elogios e críticas ao trabalho de cada membro, mas mantem-se distante da participação ativa do grupo, exceto quando para demonstrar controle. Ele pode ser amigável ou impessoal e não abertamente hostil. 


\section{- O Líder Democrático}

1) Todas as políticas de uma questão de discussão em grupo e decisão, encorajados e auxiliados pelo líder

2) Demonstra suas expectativas durante a primeira atividade em grupo. Esboça as etapas gerais para a meta do grupo, e onde aconselhamentos técnicos são necessários. O líder costuma sugerir dois ou três procedimentos alternativos a partir do qual a escolha pode ser feita

3) Os membros são livres para trabalhar com quem quer que escolham. A divisão de tarefas é deixada para o grupo

4) O líder é objetivo e pontual em seus elogios e críticas e tenta ser um membro regular do grupo, sem fazer muito do trabalho

\section{- $\quad$ Líder Laissez-faire}

1) Completa liberdade para o grupo ou decisão individual, sem qualquer participação do líder

2) Vários materiais fornecidos pelo líder, que deixa claro que irá fornecer informações quando solicitado. Não toma nenhuma outra parte em discussões de trabalho

3) Completa não-participação do líder

4) Comentários muito pouco frequentes em atividades com os membros, a menos que questionado, e nenhuma tentativa para participar ou interferir com o curso dos acontecimentos 
Quando o foco se dirige para os ambientes virtuais, uma atitude Laissez-faire pode repercutir em perda de motivação e, consequentemente, de oportunidades de aprendizagem pelos alunos (PELLICIARI; CAZARINI, 2011), uma vez que a aparente inércia por parte do docente, engajado em promover o pensamento critico no estudante, por exemplo, por meio do PBL, pode repercutir negativamente na motivação dos estudantes durante o semestre de aula. Estudando mais a fundo esse estilo comportamental, Keynes (1983) verifica que o termo Laissez-faire originou-se de muitas fontes de pensamento e de diferentes impulsos dos sentimentos na disposição com respeito às questões públicas, que por conveniência denomina-se individualismo. Comenta que a máxima Laissez-nous faire é atribuída a uma frase que o comerciante Legendre dirigiu a Colbert, por volta do fim do século XVII. Complementa informando que não há equívoco que o primeiro autor a empregar a frase, usando-o numa clara associação com a doutrina, foi o Marquês d'Argenson, aproximadamente em 1751. O Marquês foi o primeiro homem a animarse pelas vantagens econômicas de os governos aceitarem o comércio livre. Dizia ele que, para governar melhor, é preciso governar menos e que a adequada causa do declínio das manufaturas estava no protecionismo que thes era concedida (KEYNES, 1983).

É importante salientar que a complexidade do sistema é altamente sensível às condições iniciais, tem memória e inclui feedback, assim sendo, demanda dos docentes muita atenção no momento de se colocar à frente dos estudantes com o estilo comportamental Laissez-faire (JOHNSON, 2007), não deixando de atentar-se que em determinados contextos de aula esse estilo comportamental pode ser benéfico, como por exemplo, no momento de instigar os estudantes a irem em busca 
de suas próprias ferramentas para a elucidação de problemas. O sucesso está no equilíbrio da correta utilização dos perfis comportamentais de liderança.

\subsubsection{Teoria da Liderança Situacional}

Essa abordagem enxerga a liderança como específica a cada situação em que ela venha a ser utilizada. Por exemplo, algumas situações podem requerer um estilo autocrático, outras podem precisar de uma abordagem mais participativa. Também propõe que diferentes abordagens de liderança sejam utilizadas em diferentes contextos em uma mesma organização (HERSEY; BLANCHARD, 1969).

Em um contexto global a liderança situacional obtém eficácia quando aplicada em universidades de pesquisa (SHAHMANDI et al., 2011).

O docente como líder aplicando princípios de uma liderança situacional pode obter um maior nível de coesão em tarefas específicas. É necessário que a liderança se desenvolva de forma a atuar como diferencial na formação de engenheiros. Como verificado por Smith (1991), desde o início dos anos 90 é observado uma lacuna nas aptidões de gestão nos engenheiros. Estas aptidões podem ser transmitidas aos engenheiros pelo docente atuando como líder situacional. Os profissionais advindos de cursos de engenharia em grande parte das ocasiões não recebem formação em gestão, como parte de sua educação. Formação em gestão, neste caso, irá dar-lhes, entre outras coisas, um modelo a seguir de como eles devem se interagir com outras pessoas no local de trabalho. Um esboço e a aplicação de um curso de liderança situacional para estudantes de engenharia pode repercutir em vantagem competividade individual no futuro profissional.

Alguns atributos são indispensáveis para o docente atuar como líder situacional, como a prontidão. Prontidão na liderança situacional é definida como o 
grau em que um subordinado demonstra a capacidade e vontade de realizar uma tarefa específica que lhe é atribuída. Hersey, Blanchard e Johnson (1996) dizem que prontidão não é um atributo pessoal, nem traços de uma pessoa, valores ou idade. Prontidão é sobre como preparar uma pessoa para executar uma tarefa específica sugerem comportamentos de liderança situacional que reflitam comportamentos ao longo das dimensões dessa teoria. Entre elas o líder explicita sobre a atribuição de deveres e responsabilidades a serem cumpridas por seus subordinados. Comportamentos de liderança dentro desta dimensão incluem comunicar o que fazer, como, quando e onde fazer as tarefas designadas. Atuar com um comportamento de relacionamento assertivo, centrar-se na capacidade do líder como facilitador para alcançar as metas desejadas por uma comunicação bidirecional, fornecendo apoio, incentivo e feedback psicológico positivo são dimensões da teoria situacional.

\subsubsection{Teoria da Liderança Complexa}

Marion (1999) defende que a teoria da liderança complexa oferece uma nova perspectiva para a pesquisa sobre liderança, considerando a liderança no âmbito da ideia de um sistema adaptativo complexo. Em tais sistemas, as relações não são primariamente definidas hierarquicamente, por estarem em sistemas burocráticos, mas pelas interações entre os agentes heterogêneos e através de redes de agentes. De acordo com Porter-O'Grady e Malloc (2003), a liderança nas organizações contemporâneas deve incluir a capacidade de antecipar, identificar e responder às ocasiões imprevisíveis. Finkelstein (2002, p. 77, tradução livre) coloca:

"Eu entendo que como pesquisadores, precisamos simplificar processos muito complexos para estudá-los com cuidado, mas o que nós estamos com medo é de que quando nós removermos a 
confusão, o vai-e-vem, a realidade que surja possa apontar nossa ignorância em não nos termos atentado ao óbvio dos erros que vínhamos cometendo."

Na realidade das organizações do século XXI e sua inerente complexidade, ter pessoas capazes de entender de forma holística as inter-relações de fenômenos sociais, econômicos e tecnológicas e entender como utilizar a força dos recursos humanos disponíveis, Ihes dá uma grande vantagem competitiva frente à concorrência no cenário deste novo século. Pessoas com estas qualidades possuem uma maior aptidão para tomar decisões mais racionais e corretas (BLUEDORN, 2002), além de prever possíveis cenários futuros (GRONN, 2002). Essa nova mentalidade começa a surgir e reconhece que os processos sociais são demasiadamente complexos para serem atribuídos a um único indivíduo ou a um fluxo de eventos previamente planejados (FINKELSTEIN, 2002; MARION; UHLBIEN, 2001).

Embora a teoria da liderança complexa seja uma abordagem cujo a ênfase em muitos momentos afasta o indivíduo como líder, de forma alguma diminui a importância da liderança como um fenômeno organizacional, mas, sim, reconhece que a liderança transcende o indivíduo, sendo fundamentalmente um fenômeno do sistema, que é um conjunto de elementos interconectados, de modo a formar um todo organizado (FINKELSTEIN, 2002; HAZY, 2006; MARION; UHL-BIEN, 2001, 2003; MEINDL, EHRLICH; DUKERICH, 1985; UHL-BIEN; MARION; MCKELVEY, 2004).

A liderança complexa deduz a liderança como um acontecimento emergente, em vez de uma pessoa em um cenário. Uma visão da teoria da complexidade sugere uma forma de liderança participativa (BROWN; GIOIA, 2002; GRONN, 2002) 
que não está em uma pessoa, mas sim em uma dinâmica interativa, em que qualquer pessoa em particular poderá participar como líder e tornar-se um seguidor em momentos diferentes, e para diferentes fins, emergindo nas interações sistêmicas entre agentes heterogêneos (MARION; UHL-BIEN, 2001, 2003). Portanto, a liderança complexa inclui uma análise descritiva das condições e processos dinâmicos dessas interações e os fenômenos emergentes:

\footnotetext{
"Há um sentimento crescente de que a mudança efetiva em uma organização tem sua própria dinâmica, um processo que não pode simplesmente seguir mudanças estratégicas tradicionais embasadas em uma visão unidirecional e que é maior e mais sutil do que pode ser gerenciado por qualquer líder único. Ela é gerada pela compreensão de muitas pessoas que tentam melhorar o todo, e se acumula, por assim dizer, por longos períodos" (HECKSCHER, 1994, p.24 - tradução do autor).
}

\subsubsection{Teoria da Liderança Path Goal}

A essência da teoria da liderança Path Goal (HOUSE, 1977) recomenda que o líder, para ser eficaz, deve se engajar em comportamentos para com os subordinados de maneira que suas habilidades complementem as lacunas por estes apresentados, revertendo em maior desempenho e unidade no trabalho (HOUSE; BAETZ, 1979). A teoria Path Goal é uma teoria didática de supervisão. Concentra-se nas relações diárias dos líderes formalmente indicados e seus colaboradores em um ambiente organizacional, e como estes líderes interferem na motivação e satisfação no ambiente de trabalho. Essa teoria foca mais nas relações entre o líder e um subordinado na realização de uma tarefa específica e menos na supervisão de um grupo. A versão inicial da teoria afirmava que a função motivacional do líder consistia em aumentar os feedbacks ao pessoal subordinado para o trabalho, 
tornando o caminho para estes feedbacks mais fácil, sem barreiras e armadilhas, aumentando as chances de melhorias na interação líder-subordinado. Em uma versão posterior, House e Mitchell (1974) adicionaram que o comportamento do líder é visto como instrumento de motivação para o colaborador na medida que o mesmo esforça-se para dar-lhe apoio, suporte e treinamento no cumprimento de suas metas, e recompensas quando atingido um desempenho eficaz, gerando satisfação imediata ou futura ao subordinado.

\subsubsection{Teoria da Liderança Carismática}

A teoria da liderança carismática (HOUSE, 1977) atribui ao carisma uma influencia intrínseca na motivação dos seguidores. Weber (1947) enfatiza que a liderança carismática nasce fora de situações estressantes, enquanto Shils (1965) argumenta que carisma não precisa nascer fora de situações estressantes. A diferença desses diferentes pontos de vista é o contexto em que cada ação é decidida. Na literatura corrente, o termo Liderança Carismática é geralmente definida e descrita em termos de efeitos do líder nos seguidores, ou em termos do relacionamento entre líder e seguidores. Oberg (1972) declara que o teste para carisma é o grau de devoção e confiança que o líder carismático inspira, e o degrau para que isso promova o individuo a transcender seus próprios interesses e alienações, sentindo-se parte do todo.

Frequentemente, o relacionamento dos seguidores para com um líder carismático é como o de um discípulo para com um mestre, em que qualquer evento o líder é reverenciado pelos seguidores. Tucker (1968) afirma que os seguidores do líder carismático não o seguem pelo medo ou recompensa monetária, mas por amor, veemente devoção e entusiasmo, e que eles não estão atuando em um papel em 
que há a preocupação com a carreira, promoção, salário ou benefícios. O seguidor do líder carismático faz parte de um grupo não burocrático.

O líder carismático é visto como sendo um objeto de identificação no qual os seguidores reproduzem seus valores, metas e comportamentos, o que torna a ética do líder fator preponderante na formação de talentos que repercutam positivamente frente a sociedade. Mais, um dos efeitos da liderança carismática nos seguidores é promover a modelagem de seus comportamentos, sentimentos e cognições (FRIEDRICH, 1961), sendo que o líder carismático pode agregar ou subtrair elementos do caráter de um individuo, transformando-o em um ser humano melhor ou pior. Docentes carismáticos devem ser zelosos para com suas funções, uma vez que tem sob sua supervisão muitos estudantes, podendo refletir neles seus próprios traços.

\subsubsection{Teoria da Liderança Transacional}

A teoria da Liderança Transacional (BASS, 1985; BURNS, 1978) enfatiza a importância do relacionamento entre os líderes e os seguidores, focando em um benefício mutuo, que lembra a um contrato, pelo qual o líder entrega determinadas coisas como recompensas ou reconhecimento em troca de um comprometimento ou lealdade de seus seguidores (BASS, 1985). Líderes transacionais veem a relação entre líder e seguidor como um processo de troca (BASS; AVOLIO, 1994) baseado em um sistema de recompensa e punição. Liderança transacional é baseada em dois fatores: recompensa eventual e gerenciamento por exceção. Um líder transacional, assim, oferece reforço positivo, prêmios, elogios e recompensas quando os objetivos são alcançados e utilizará o reforço negativo, como castigo e 
punição, quando erros são cometidos ou falhas ocorrem. Uma outra dimensão da liderança transacional é em relação ao "timing" de ação do líder quando se confronta com um problema. Como observado por Avolio, Bass e Jung (1999), a diferença entre a gestão por exceção-ativa e gestão por exceção-passiva reside no momento da intervenção do líder, ou timing. Os líderes ativos monitoraram o comportamento do seguidor, antecipam problemas e tomam ações disciplinares antes que 0 comportamento crie sérias dificuldades. Os líderes passivos esperam até que o comportamento tenha criado problemas antes de tomar atitudes.

Diante dessas informações é possível vislumbrar a importância do domínio desse perfil de liderança em ambientes híbridos, uma vez que a competência nesses atributos pode otimizar o processo ensino-aprendizagem.

\subsubsection{Teoria da Liderança Transformacional}

O conceito central aqui é a mudança e o papel da liderança em envolver e implantar a transformação no desempenho organizacional. A Liderança Transformacional é baseado em quatro fatores principais: a influência idealizada (ou "carisma"), a motivação inspiradora, estimulação intelectual e consideração individualizada (BASS; AVOLIO, 1994).

1) Comportamento idealizado / Carisma

- Comunica altas expectativas para os seguidores, muitas vezes usando símbolos ou apelos emocionais

- Fala sobre seus mais importantes valores e crenças

- Especifica a importância de ter um forte senso de propósito 
- Considera a moral e a ética consequência de decisões

- Campeões desejam novas possibilidades

- Fala sobre a importância de acreditar um nos outros

2) Motivação Inspiradora

- Fala otimistamente sobre o futuro

- Fala entusiasticamente sobre o que precisa ser alcançado

- Articula positiva visão de futuro

- Expressa confidência de que as metas serão alcançadas

- Providencia uma excitante imagem do que é necessário se considerar

- Toma um caminho em questões controversas

- Comunica altas expectativas para os seguidores, muitas vezes usando símbolos ou apelos emocionais

3) Estimulação Intelectual

- Reexamina assuntos críticos para verificar se eles são apropriados

- Procura diferentes perspectivas quando está resolvendo um problema

- Solicita ajuda para que uma questão seja vista de diferentes ângulos

- Sugere novos caminhos para observar como atingir determinadas metas

- Encoraja pensamentos não tradicionais para lidar com problemas tradicionais

- Encoraja repensar todas as ideais que antes não foram questionadas

- Seguidores são incentivados a serem criativos e inovadores para desafiarem suas próprias crenças e valores, bem como as do líder e da organização 
4) Consideração individual

- Emprega tempo ensinando e capacitando a equipe

- Trata os outros como indivíduos mais do que apenas membros de um grupo

- Considera indivíduos como tendo diferentes necessidades, habilidades e aspirações do que outros

- Ajuda os outros a desenvolverem seus esforços

- Ouve atentamente a preocupação dos outros

- Promove o autodesenvolvimento

- Demonstra um alto grau de preocupação pessoal para as necessidades dos seguidores

Outros atributos que podem ser analisados na liderança transformacional

- Instila orgulho nos outros por estar associado com eles

- Vai além dos interesses próprios em detrimento do melhor para o grupo

- Atua em caminhos que fomenta o respeito dos outros

- Demonstra senso de poder e competência

- Faz sacrifícios pessoais para o benefício dos outros

- Reafirma nos outros que os obstáculos serão transpassados

Martin et al. (2003) atestam que a liderança transformacional em um contexto do ensino superior está ligada aos resultados muito positivos na mensuração do aprendizado dos estudantes devido a uma alta qualidade alcançada pelo docente no 
processo ensino-aprendizagem seja qual for o método empregado. Pounder (2001) sugere que a liderança transformacional não é apenas a chave para uma liderança eficaz no ensino superior, com resultados consolidados, mas que existe de fato uma forte presença do estilo de liderança transformacional atualmente na educação superior. Isso se dá como estratégias de inovação pelas IES com vistas a uma adequação aos desafios de uma sociedade envolta em rápidas mudanças e que necessita de uma mão de obra formada com o alicerce no pensamento crítico, que necessita de motivação para reaprender a aprender, características que um líder transformacional pode fomentar em seus colaboradores (HOWELL; AVOLIO, 1993), mas muito pouco disseminada no Brasil.

Complementando a análise de alguns perfis de liderança, surge um questionamento de como as mulheres estão se comportando em um momento em que cada vez mais assumem o papel de líderes em vários seguimentos. Em uma meta análise de 45 estudos, os líderes do sexo feminino demonstram mais aspectos transformacionais do que os líderes transformacionais masculinos em seu estilo de liderança quando alcançaram maior nível de desempenho no gerenciamento de equipes nas organizações. Uma vantagem geral do sexo feminino também foi encontrado em relação à característica carismática e um de seus componentes, a Influência Idealizada (atributo), bem como nas sub-escalas da liderança transformacional, como a motivação Inspiradora, estimulação intelectual e consideração individualizada. Na liderança transacional, líderes femininas pontuaram mais do que líderes do sexo masculino no item da negociação de recompensa. No entanto, líderes masculinos pontuaram mais do que lideranças femininas em relação à gestão por exceção ativa e gestão por exceção passiva, subescalas de liderança transacional. Além disso, os homens pontuaram mais alto do 
que as mulheres na escala de Laissez-Faire (EAGLY; ENGEN; JOHANNESENSCHMIDT, 2003).

\subsubsection{0 e-líder}

Como podemos observar, nesse século XXI a tecnologia se mostra como um fator crítico de sucesso das organizações, que necessita de times cujo os líderes permitam a produção de novas estruturas e culturas agregando valor aos novos modelos de negócio, como o comércio eletrônico e redes sociais. Tais líderes foram definidos como e-líderes por Avolio e Kahai (2002), baseando-se para isso na teoria da estrutura adaptativa (DESANCTI; POOLE, 1994), onde buscaram elementos que dessem respaldo para que a TIC fosse tratada de uma forma que fornecesse elementos para que esses novos atores, os e-líderes, pudessem atuar com vistas a alcançarem um alto nível de desempenho junto aos desafios da liderança em ambientes virtuais de colaboração.

Neste contexto de ambientes presenciais e virtuais integrando-se, pesquisadores determinaram algumas variáveis entre a liderança face a face e a praticada em ambientes virtuais. Um dos fatores que mais chamaram a atenção dos pesquisadores foi a de que, tanto em um como em outro ambiente, a satisfação pessoal do colaborador para com o trabalho está diretamente relacionada à capacidade transformacional do seu líder, a capacidade de influenciar positivamente as pessoas e modificar o ambiente de trabalho transformando-o em fonte de aprendizagem e não somente de cumprimento de funções específicas e repetitivas, que não agregam novos valores para o colaborador (AVOLIO; KAHAI, 2002).

Ser membro de equipes que trabalham em ambientes virtuais permite uma maior flexibilidade ao colaborador, facilitando a ação do líder em um ambiente onde 
a pressão se atenua pela ausência do contato físico. Os membros de equipes virtuais geralmente têm maior liberdade em suas programações e não são necessariamente confinados a dias de trabalho tradicionais como em seus escritórios físicos separados por estruturas organizacionais que dificultam a comunicação entre os colaboradores, podendo trabalhar em suas casas (CASCIO; SHURYGAILO, 2003). Assim, estruturas organizacionais físicas muito engessadas inibem a disseminação de conhecimentos e o comprometimento para com as metas, ao mesmo tempo que um ambiente virtual de colaboração pode gerar um sentimento de isolamento dos indivíduos, e perda de produtividade (COHEN; MANKIN, 1999).

O líder deve atentar-se a esses limitadores e caminhar atentamente pela estreita linha que separa os prós e os contras quando incumbido de assumir um desafio no qual a meta deva passar tanto como por interações face a face entre membros do time como também por ambientes virtuais (DEROSA et al., 2004).

É preciso também entender que as mídias sociais e a TIC tem sido analisadas como facilitadoras na execução de processos de trabalho no cumprimento de metas pelos colaboradores, mas esses processos ainda precisam ser melhor avaliados e conduzidos pelos gestores. Esse ponto de vista é compartilhado desde o final dos anos oitenta (JOHANSEN, 1989) até os dias atuais, passando pelo paradigma da privacidade e retenção de informações como forma de poder (STUTZMAN et al., 2011), que se estende desde as redes sociais tradicionais, como os grupos de pessoas unidas presencialmente, assim como nas redes sociais virtuais. Isso significa que o trabalho em equipe com qualidade não acontece quando 0 conhecimento fica retido na mente de quem o possui, que pelo medo de compartilhar o conhecimento e perder poder, acaba por prejudicar a própria equipe, e a organização, por conseguinte. 
O e-líder necessita destas percepções do que pode estar acontecendo na mente dos colaboradores para estar redirecionando-os para o objetivo de um determinado projeto, que esteja sendo conduzido por pessoas em ambientes virtuais, quando esta equipe se distancia por dificuldades de comunicação e barreiras psicológicas, como ansiedade. Essa atenção deve se dar em todas as dimensões do gerenciamento de equipes, tanto em uma organização onde se trabalha face a face como no gerenciamento de pessoas em redes sociais, como 0 Facebook e o Twitter, do mesmo modo como em groupwares. Assim, o e-líder é aquele que confronta o real com o virtual, conduzindo pessoas para a realização de metas em consoante com os objetivos a que se propõe um determinado projeto, tendo a TIC presente nos processos.

Purvanova e Bono (2009) identificam na literatura que características de liderança em um ambiente tradicional pode migrar para os ambientes virtuais de colaboração e enaltecem as características da liderança transformacional como fomentadoras de coesão entre membros de uma equipe trabalhando em um ambiente virtual, ao mesmo tempo que identificam lacunas a serem preenchidas quanto à validação dessa nova abordagem de liderança inserida no contexto dos ambientes virtuais de colaboração. O líder e o e-líder se complementam, mas em muitos casos necessitam de atuações diferentes para obterem um mesmo resultado. Estudos relacionados às características que o e-líder deve desempenhar em um ambiente virtual de colaboração ainda são escassos.

\subsubsection{Líder Sábio}

Recentemente Nonaka e Takeuchi (2011), de acordo com seus estudos, afirmaram que a sabedoria natural é o conhecimento experimental que permite que 
as pessoas façam julgamentos eticamente corretos. Dizem que é semelhante ao conceito japonês de toku-a, em que a virtude leva uma pessoa a buscar a excelência no bem comum, e a moral como uma forma de vida. Continuando, afirmam que a sabedoria natural é semelhante ao conceito indiano de yukta, que conota justo direito ou adequado. Por exemplo, os executivos que acreditam que o propósito de um negócio, e até mesmo os lucros, são para servir as pessoas e melhorar a sociedade pela observação do yukta, que coíbe excessos de ganância.

Segundo Nonaka e Takeuchi (2011), os líderes sábios podem julgar com afabilidade por meio de alguns atributos intrinsicamente presentes em seu ser, como:

1) Experiência: Um deles é a experiência, particularmente a adquirida por enfrentar a adversidade ou o fracasso. Outra forma é escrever os princípios retirados de experiências de vida e compartilhá-los

2) Ideias: Coloque em prática boas ideias, mova o mundo, mude a sociedade e contribua para sua melhoria. Recompense boas condutas e puna a maldade; Exija o mais alto nível de ética em seu negócio e trabalho

3) Busca incessante da excelência com ênfase na qualidade de vida das pessoas, sem corte de custos

4) Capacidade de julgamento aprimorada pelo estudo das artes liberais, tais como filosofia, história, literatura e as artes plásticas

5) Líderes sábios compartilham contextos

6) Constantemente criam oportunidades para altos executivos e funcionários aprenderem uns com os outros

7) Líderes sábios comunicam a essência

8) Líderes Sábios exercitam a Sabedoria Prática (Phronetic) 
9) Líderes sábios promovem a Sabedoria prática nos outros

Seria por meio da disseminação da sabedoria do mestre, e a replicação da mesma pelo discípulo, que a sociedade alcançaria um novo nível de desenvolvimento e evolução, cobrindo com estas as lacunas deixadas pela maneira exacerbada de se praticar o capitalismo, que tem trazido mais perdas que ganhos ao planeta. Esse pensamento levado para as IES poderia ser um fator crítico de sucesso na fase de implantação de mudanças voltadas para as melhores práticas de se educar os estudantes.

\subsection{Liderança, Motivação e Princípios de Aprendizagem}

Toda organização necessita de uma visão de futuro que a norteie com vistas à manutenção ou ao crescimento de seus negócios. Uma vez que as organizações são feitas de pessoas, a visão nesse cenário se refere a um quadro do futuro com algum comentário implícito ou explícito sobre por que as pessoas devem se esforçar para criar esse futuro. Para isso, a motivação dos colaboradores para estarem sempre dispostos a aprenderem novas habilidades, ou aperfeiçoarem as já existentes, se mostra preponderante (ERICKSON, 1974; KOTTER, 1996). Os estudantes de hoje serão os colaboradores das organizações no futuro, assim, é importante frisar que, independentemente do estilo de aprendizagem do estudante, e sua inteligência básica, ele ou ela não vai aprender se não for motivado. Kolstoe (1975) afirma que ninguém pode ensinar nada a ninguém se não houver motivação.

O docente como líder poder gerar essa energia motivadora. Em uma análise de cursos de engenharia elaborada nos Estados Unidos da América, pesquisadores identificaram que os estudantes podem ter uma variedade de problemas de motivação. A solução muitas vezes depende do problema. Um resumo elaborado 
tendo como referencia a publicação WHAT Works (1986) demonstra a importância da motivação para os estudantes de engenharia no momento que aponta várias situações que demonstram as inseguranças vivenciadas por estes:

1) O estudante não quer estudar engenharia ou mesmo ir para a faculdade. Um número surpreendente de estudantes estão na engenharia por causa da pressão dos pais. $O$ fracasso é uma forma do estudante poder provar que os pais estão errados. Pesquisas mostram claramente que os estudantes que não acreditam na importância da educação têm menor sucesso na escola

2) O estudante não está sob pressão na engenharia, mas é incerto se a engenharia é a melhor escolha. Como os estudantes precisam ver significado em seus estudos, o esforço da motivação pode se concentrar nisso. Uma vez que um propósito é incutido, esses estudantes podem tornar-se engenheiros excelentes

3) Alguns estudantes encontram muita competição nas aulas de engenharia e sentem que eles nunca são recompensados por seus esforços

4) Problemas externos são muito adversos. Uma morte na família, problemas de saúde, dificuldades financeiras, problemas de relacionamento, e assim por diante, pode evitar que os estudantes sejam motivados em seus estudos

5) O estudante torna-se muito ansioso durante as avaliações ou ao fazerem as tarefas extraclasse. $O$ desconforto causado pela ansiedade excessiva pode reduzir a motivação. Alta tensão em testes é prejudicial a todos os estudantes, mas atinge as mulheres mais dificilmente do que os homens (MCKEACHIE, 1986). Ansiedade e estresse podem ser controlados por 
procedimentos de dessensibilização (por exemplo, dando mais testes), por métodos de relaxamento e dando ao estudante mais controle sobre a nota que ele ou ela vai ganhar

6) O estudante quer apenas um diploma e não se importa em aprender os temas. Embora o docente possa pensar que o estudante é motivado pela razão errada, como apenas a obtenção do diploma ou satisfação dos pais, essas motivações podem ser usados para obter maior comprometimentos nos processos de aprendizagem nos mesmos

7) O estudante não é inteligente o suficiente. Coloca-se esta última razão, pois, ao contrário da opinião de muitos docentes, a falta de capacidade intelectual raramente é a principal razão para a falta de motivação, embora possa contribuir, particularmente para os estudantes de engenharia. Uma gama significativa de pesquisas mostram que a realização de uma atividade específica é muitas vezes mais dependente de trabalho duro e autodisciplina do que da habilidade inata

Grande parte dos escritores sobre a motivação no ensino universitário, por exemplo, Eble (1988) e McKeachie (1986), notam que os docentes precisam ser criativos no desenvolvimento de técnicas de motivação para os estudantes sentiremse mais confiantes na resolução de problemas e retenção do conhecimento adquirido.

Vale observarmos que os princípios das teorias da liderança se encaixam com compêndios de princípios de aprendizagem. Para comprovar tal fato, um resumo foi elaborado para compreendermos o quanto importante é o docente dominar técnicas de liderança no ambiente de aula. Entre os princípios destacados por Chickering e Gamson (1987), Durney (1973) e Wales (1976), nos livros de Elbow (1986), 
McKeachie (1986) e Peters e Waterman (1982), e no manual What Works (1986), temos as seguintes estratégias a serem utilizadas pelo docente:

1) Guiar o estudante. Certifique-se que os estudantes saibam os objetivos. Indicar qual vai ser o próximo objetivo. Proporcionar organização e estrutura adequadas para o desenvolvimento das atividades

2) Desenvolver uma hierarquia estruturada de conteúdo. A organização no material deve ser clara, mas deve haver oportunidades para o estudante fazer alguma estruturação própria por meio de suas percepções para com o contexto. 0 conteúdo deve incluir conceitos, aplicações e resolução de problemas

3) Usar a aprendizagem visual, imagens. A maioria das pessoas preferem a aprendizagem visual e têm melhor retenção de informações quando este modo é utilizado. Incentivar os estudantes a gerarem seus próprios mecanismos de aprendizagem visual

4) Verificar se o estudante é ativo. Os estudantes devem lidar ativamente com o material. Isto pode ser feito internamente ou externamente, por escrito ou falando

5) Exigir prática. A aprendizagem de conceitos complexos, tarefas ou resolução de problemas exige a oportunidade de praticar em um ambiente não ameaçador. Alguma repetição é necessária para o estudante tornar-se rápido e exato na resolução de problemas

6) Fornecer feedback. O feedback deve ser rápido e, se possível, positivo. Recompensa funciona muito melhor do que punição. Estudantes precisam de uma segunda chance para a prática após o feedback, a fim de beneficiar-se plenamente a partir dele

7) Ter expectativas positivas para com os estudantes. Expectativas positivas e respeito do docente são altamente motivadores. Baixas expectativas e desrespeito 
são desmotivadores. Este é um princípio muito importante, mas não pode ser aprendido como um método. Um mestre realmente acredita que seus estudantes ou a sua equipe são capazes de grandes coisas

8) Fornecer meios para que os estudantes alcancem os objetivos propostos na disciplina. Certifique-se que os estudantes têm conhecimento de base adequado. Dar tempo suficiente e tarefas que todos possam obter sucesso, mas não se esqueça que há um desafio para todos. O sucesso é muito motivador

9) Individualizar o estilo de ensino. Use uma variedade de estilos de ensino e aprendizagem de exercícios para que cada estudante possa usar o seu estilo favorito e de modo que cada estudante se torne mais proficiente em todos os estilos

10) Verificar a classe mais cooperativa. Use exercícios em grupo para capacitar os estudantes no trabalho em equipe

11) Pedir questões instigantes, que não tenham de ter necessariamente respostas. Fazer perguntas sem resposta pode ser particularmente motivador para os estudantes mais maduros

12) Ser entusiasta e demonstrar a alegria para com a aprendizagem. $O$ entusiasmo é motivador e ajuda os estudantes a aproveitar a classe

13) Incentivar os estudantes a ensinar outros estudantes

14) Cuidar do que você está fazendo. O docente que coloca o ensino no automático não pode fazer um excelente trabalho

15) Se possível ensinar, separado da avaliação. Se uma pessoa diferente faz a avaliação, o docente pode se tornar um treinador e um aliado, cujo objetivo é ajudar o estudante a aprender

É necessário ainda entender o grau de maturidade escolar entre estudantes novatos e especialistas, o que é mostrado na Figura 3. 
Especialistas têm cerca de 50.000 pedaços de conhecimento especializado e padrões armazenados em seus cérebros de uma forma facilmente acessível (SIMON, 1979). O especialista tem os conhecimentos ligados de alguma forma e não armazena fatos desconexos. Exercícios que exigem que os estudantes desenvolvam as árvores ou as redes neurológicas podem ajudá-los a formar ligações apropriadas (STAIGER, 1984). O acúmulo de conhecimentos ligados requer cerca de 10 anos. Como não é viável acumular estas informações em quatro ou cinco anos, que é o tempo médio de um curso superior em engenharia, produzir especialistas não é uma meta realista para a educação neste segmento.

No entanto, é um tempo razoável para moldar solucionadores de problemas proficientes que têm o potencial para se tornar especialistas, depois de mais tempo em seus campos de atuação.

A Figura 3 mostra as características peculiares entre novatos e especilistas no processo ensino-aprendizagem. 


\begin{tabular}{|c|c|c|}
\hline Características & Novatos & Especialistas \\
\hline Memória & Pequenos pedaços, Alguns itens & "Pedaços" ou padrão 50 mil itens \\
\hline Atitude & $\begin{array}{l}\text { Tenta uma vez, depois desiste, } \\
\text { caindo em ansiedade }\end{array}$ & Persistentes e confiantes \\
\hline Classificar & Detalhes superficiais & Apoiam-se em fundamentos \\
\hline Declaração do Problema & $\begin{array}{l}\text { Apresenta dificuldade em } \\
\text { reescrever o problema; É Lento e } \\
\text { impreciso; Vai logo para conclusão }\end{array}$ & $\begin{array}{l}\text { Muitas técnicas para redescrever; } \\
\text { Rápidos e precisos; } \\
\text { Leva um tempo definindo o problema } \\
\text { antes de buscar a solução; } \\
\text { Pode redefinir várias vezes o mesmo } \\
\text { problema }\end{array}$ \\
\hline Definição do problema & Lento; Trabalha de trás pra frente & $\begin{array}{l}\text { quatro vezes mais rápidos; Trabalha a } \\
\text { frente com o conhecido }\end{array}$ \\
\hline Estratégia & Tentativa e erro & Usa uma estratégia \\
\hline Informação & $\begin{array}{l}\text { Não sabe o que é relevante; } \\
\text { Não pode fazer inferências } \\
\text { a partir de dados incompletos }\end{array}$ & $\begin{array}{l}\text { Reconhecer as informações } \\
\text { relevantes; Pode fazer inferências }\end{array}$ \\
\hline Partes (Problemas Difíceis) & Não analisa por partes & $\begin{array}{l}\text { Analisa as partes; Procede por passos; } \\
\text { Procura por padrões }\end{array}$ \\
\hline $\begin{array}{lll}\begin{array}{l}\text { Primeiro passo } \\
\text { difíceis) }\end{array} & \text { (Problemas } \\
\end{array}$ & $\begin{array}{l}\text { Tenta calcular (apenas } 1 \text { (um) } \\
\text { passo) }\end{array}$ & $\begin{array}{l}\text { Define e desenha; Esboça o problema; } \\
\text { Explora }\end{array}$ \\
\hline Esboço & Frequentemente não faz & $\begin{array}{l}\text { Leva um tempo considerável; Releva } \\
\text { princípios abstratos; Segue um } \\
\text { continuum }\end{array}$ \\
\hline Limites & Não calcula & $\begin{array}{l}\text { Pode calcular para obter rápida } \\
\text { resolução do problema }\end{array}$ \\
\hline Equações & $\begin{array}{l}\text { Memoriza ou procura } \\
\text { detalhadamente por } \\
\text { equações para cada circunstância }\end{array}$ & $\begin{array}{l}\text { Usa as relações fundamentais para } \\
\text { obter o resultado necessário }\end{array}$ \\
\hline Processos de Solução & $\begin{array}{l}\text { "Incompletos"; Decidem como } \\
\text { resolver depois de escrever a } \\
\text { equação }\end{array}$ & $\begin{array}{l}\text { Compila os procedimentos das } \\
\text { equações e métodos em um único } \\
\text { procedimento }\end{array}$ \\
\hline $\begin{array}{l}\text { Monitoramento do progresso } \\
\text { da solução }\end{array}$ & Não faz & Mantem o controle; gerencia o tempo \\
\hline Em caso de bloqueio & Tenta adivinhar; desiste & Usa Heurística; Persevera; Brainstorm \\
\hline Acurácia & $\begin{array}{l}\text { Não se preocupa; Não faz } \\
\text { checagens }\end{array}$ & $\begin{array}{l}\text { Muita acurácia; Faz a checagem várias } \\
\text { vezes }\end{array}$ \\
\hline Medição dos resultados & Não faz & Faz a partir de uma ampla experiência \\
\hline $\begin{array}{l}\text { Erros ou Falhas para resolver } \\
\text { problemas }\end{array}$ & Ignora & $\begin{array}{l}\text { Sabe o que deveria ter feito; } \\
\text { Desenvolve um novo método para a } \\
\text { solução }\end{array}$ \\
\hline Ações & Senta e pensa; Inatividade; Silêncio & $\begin{array}{l}\text { Uso de papel e lápis; muito ativo. } \\
\text { Esboça as questões e escreve os } \\
\text { fluxos dos processos }\end{array}$ \\
\hline Decisões & $\begin{array}{l}\text { Não entende o processo; } \\
\text { Nenhum critério claro }\end{array}$ & $\begin{array}{l}\text { Compreende o processo de decisão } \\
\text { com um critério claro }\end{array}$ \\
\hline
\end{tabular}

Figura 3 - Comparação do processo de aprendizagem entre inexperientes e especialistas

Fonte - Adaptado de Wankat e Oreovicz (1992a)

Após uma análise mais acurada desses princípios, torna-se claro o quanto a liderança adequada do docente pode acrescentar qualidade ao ensino na 
engenharia uma vez que em todos os tópicos observamos congruência entre a liderança e a arte de ensinar e a arte de aprender. Motivar os estudantes a superarem os seus problemas emerge como uma característica de um docente como líder transformacional, no momento que o docente, pela visão holística da classe, pode identificar determinados traços de comportamento que possibilite ao mesmo atuar individualmente e com inspiração motivadora, de acordo com cada situação (POUNDER, 2001).

Outro fator motivacional deve ser considerado e é o relacionado aos processos de ensino e aprendizagem e também aos estilos e estratégias de aprendizagem dos estudantes.

Aprender e ensinar na engenharia (FELDER; SILVERMAN, 1998) passa pelo paradigma do entendimento das diferenças de aprendizagem entre os estudantes (FELDER; BRENT, 2005). O docente como líder de uma equipe de estudantes deve dominar as dimensões dessas diferenças para que possa exercer sua função com uma qualidade mensurada pelo nível de aprendizado alcançado pelos estudantes.

O Grupo de Pesquisa Aprendizagem em Engenharia - APRENDE Educação para o novo milênio do Departamento de Engenharia de Produção da Escola de Engenharia de São Carlos, USP, que "tem como finalidade investigar e intervir nos processos de geração, modelagem, transferência e mensuração do conhecimento específico da Engenharia de Produção, em todas suas áreas de atuação" (APRENDE..., 2012), propõe a realização do mapeamento individual e das interfaces das seguintes áreas: Gestão Organizacional, Gestão do Conhecimento e Desenvolvimento de competências. 
Como parte de seus estudos, o Grupo APRENDE sintetizou ensinamentos identificados em leituras do Dr. Richard Felder e Dr. David Keirsey sobre o mapeamento dos estilos e estratégias de aprendizagem (FELDER, 1996).

\footnotetext{
"Estilo de Aprendizagem pode ser definido como a maneira pela qual cada pessoa percebe e processa as informações, ou uma combinação de diversas dimensões psicológicas e cognitivas, em variadas intensidades, que nos fazem perceber e processar as informações de modo particular" (APRENDE..., 2012).
}

Nessa síntese identificaram que o modelo de Felder enfatiza dimensões relacionadas ao aprender em atividades de ensino ou treinamento. Os pares de dimensões propostos por Felder são: Ativo / Reflexivo; Sensorial / Intuitivo; Visual / Verbal; Seqüencial / Global (APRENDE..., 2012).

Devido à complexidade do processo ensino-aprendizagem, cabe ao estudante identificar, por meio da análise de suas próprias dimensões de aprendizagem, como se programar mentalmente para a resolução de problemas entregues por um docente ou, quando em uma empresa, pelo seu superior (RAMSDEN, 1998).

Na Figura 4 é apresentado um resumo do trabalho do Grupo APRENDE referente a esse caso em específico e que pode ser observado e incorporado ao conhecimento tácito do docente, enquanto líder, para que o mesmo possa externalizá-lo em ambientes híbridos de aprendizagem, da forma que melhor se enquadre nas tentativas de gerar um melhor aprendizado em seus estudantes. 


\begin{tabular}{|c|c|c|}
\hline Dimensões & & \\
\hline Ativo/Reflexivo & Resumo & O que pode ser feito pelo estudante \\
\hline ATIVO & \multirow[t]{2}{*}{$\begin{array}{l}\text { Os autores apontam que o } \\
\text { equilíbrio entre as duas } \\
\text { categorias, Ativo e } \\
\text { Reflexivo é ideal, pois uma } \\
\text { decisão pode causar sérias } \\
\text { consequências se tomada às } \\
\text { pressas, sem refletir ou } \\
\text { amadurecer a questão. E, por } \\
\text { outro lado, a fase de reflexão } \\
\text { pode ser tão demorada e } \\
\text { detalhada que a decisão pode } \\
\text { perder seu valor ou } \\
\text { oportunidade. }\end{array}$} & $\begin{array}{l}\text { Ao participar de uma atividade (aula, reunião de } \\
\text { negócios, comitê) em que não é enfatizada a } \\
\text { discussão de um problema prático ou sua } \\
\text { solução, compense essa divergência com seu } \\
\text { estilo de aprendizagem preparando-se antes, } \\
\text { tentando prever as decisões e suas } \\
\text { consequências. Trabalhe ou estude com um } \\
\text { grupo, no qual os integrantes expliquem } \\
\text { diferentes tópicos uns aos outros. Procure } \\
\text { antever o que lhe pode ser perguntado, levante } \\
\text { diferentes cenários e estabeleça planos de ação. } \\
\text { Você vai reter melhor a informação se identificar } \\
\text { maneiras de utilizá-la de forma prática. }\end{array}$ \\
\hline REFLEXIVO & & $\begin{array}{l}\text { Ao participar de uma atividade em que se } \\
\text { concede pouco ou nenhum tempo para refletir } \\
\text { (pensar) sobre um problema ou uma nova } \\
\text { informação, compense essa divergência com seu } \\
\text { estilo de aprendizagem ao estudar o assunto. Não } \\
\text { se limite a ler e memorizar o material, faça } \\
\text { paradas periódicas para revisar o que leu e para } \\
\text { pensar em possíveis questões ou aplicações. } \\
\text { Pode ser bastante efetivo escrever pequenos } \\
\text { resumos do material ou fazer anotações, com } \\
\text { suas próprias palavras. Isso lhe permitirá reter o } \\
\text { material de modo mais efetivo. }\end{array}$ \\
\hline Sensorial/Intuitivo & \multirow{3}{*}{$\begin{array}{l}\text { Resumo } \\
\text { Para ser um aprendiz } \\
\text { eficiente e bom solucionador } \\
\text { de problemas, você precisa } \\
\text { estar apto a utilizar essas } \\
\text { duas dimensões. Ao } \\
\text { enfatizar demasiadamente } \\
\text { seu lado intuitivo, você pode } \\
\text { deixar escapar detalhes } \\
\text { importantes ou cometer } \\
\text { erros, nos cálculos ou nos } \\
\text { trabalhos práticos, por falta } \\
\text { de atenção. Se for enfatizada } \\
\text { sua preferência sensorial, } \\
\text { você irá confiar } \\
\text { demasiadamente na memória } \\
\text { e nos métodos tradicionais, } \\
\text { em detrimento de um } \\
\text { raciocínio inovador. }\end{array}$} & O que pode ser feito pelo estudante \\
\hline SENSORIAL & & $\begin{array}{l}\text { Sensoriais compreendem e retêm melhor a } \\
\text { informação se percebem como ela se relaciona } \\
\text { com o mundo real. Se você participa de um } \\
\text { evento ou aula, por exemplo, onde o assunto é } \\
\text { tratado de uma forma teórica e abstrata, você } \\
\text { pode se sentir desconfortável. Peça ao docente } \\
\text { exemplos específicos, e descubra como os } \\
\text { conceitos são aplicados na prática. Caso não se } \\
\text { sinta satisfeito, procure mais exemplos em outras } \\
\text { referências ou discuta o assunto com outras } \\
\text { pessoas. }\end{array}$ \\
\hline INTUITIVO & & $\begin{array}{l}\text { As aulas expositivas são normalmente mais } \\
\text { aproveitadas pelos intuitivos. No entanto, se } \\
\text { você é intuitivo e está assistindo a uma aula que } \\
\text { exige memorização e aplicação rotineira de } \\
\text { fórmulas, você pode se aborrecer. Peça ao } \\
\text { docente para mostrar como os fatos estão ligados } \\
\text { uns aos outros ou procure você mesmo as } \\
\text { conexões. Você pode cometer erros nas provas } \\
\text { por ser impaciente com detalhes e não gostar de } \\
\text { repetição como, por exemplo, conferir um } \\
\text { problema resolvido. Leia a questão inteira antes } \\
\text { de iniciar a responder e procure conferir os } \\
\text { resultados. }\end{array}$ \\
\hline Visual/Verbal & Resumo & O que pode ser feito pelo estudante \\
\hline VISUAL & $\begin{array}{l}\text { Aprendizes } \quad \text { visuais } \\
\text { relembram melhor o que } \\
\text { viram, os verbais tiram mais } \\
\text { proveito das palavras. Todos }\end{array}$ & $\begin{array}{l}\text { Se você é visual, procure por diagramas, } \\
\text { esquemas, figuras ou faça você mesmo uma } \\
\text { representação esquemática do material que está } \\
\text { apresentado de forma predominantemente }\end{array}$ \\
\hline
\end{tabular}




\begin{tabular}{|c|c|c|}
\hline & $\begin{array}{l}\text { aprendem melhor quando a } \\
\text { informação é apresentada } \\
\text { visual e verbalmente. Nos } \\
\text { cursos superiores, de um } \\
\text { modo geral, as aulas ainda } \\
\text { são dadas com pouca } \\
\text { utilização de informação } \\
\text { visual (figuras, diagramas, } \\
\text { fluxogramas, esquemas, } \\
\text { filmes), normalmente os }\end{array}$ & $\begin{array}{l}\text { descritiva, verbal. Pergunte ao docente se } \\
\text { existem filmes sobre o material, pesquise na } \\
\text { internet por apresentações multimídia. Utilize } \\
\text { marcadores de texto, de várias cores. Use uma } \\
\text { mesma cor quando quiser relacionar itens. } \\
\text { Sistematize as informações, identifique os } \\
\text { conceitos principais e suas conexões, prepare um } \\
\text { esquema destacando graficamente esses } \\
\text { elementos e suas ligações (blocos e linhas). }\end{array}$ \\
\hline VERBAL & $\begin{array}{l}\text { estudantes ficam passivos } \\
\text { ouvindo preleções, tomando } \\
\text { notas do material escrito ou } \\
\text { projetado pelo docente. Os } \\
\text { levantamentos preliminares } \\
\text { indicam que a maioria das } \\
\text { pessoas é visual, o que quer } \\
\text { dizer que a grande maioria } \\
\text { dos estudantes poderia ser } \\
\text { beneficiada se as } \\
\text { apresentações fossem mais } \\
\text { visuais. Os melhores } \\
\text { aprendizes são os que } \\
\text { processam a informação de } \\
\text { forma visual e verbal. }\end{array}$ & $\begin{array}{l}\text { Prepare resumos do material que está sendo } \\
\text { estudado, usando suas próprias palavras. Isso } \\
\text { favorece também seu entendimento sobre o } \\
\text { assunto. Sempre que possível trabalhe em } \\
\text { equipe, sua compreensão será melhor se você } \\
\text { ouvir as explicações de seus colegas e procurar } \\
\text { expor o material para eles. }\end{array}$ \\
\hline Sequencial/Global & Resumo & O que pode ser feito pelo estudante \\
\hline SEQUENCIAL & $\begin{array}{l}\text { Aprendizes sequenciais } \\
\text { tendem a processar as } \\
\text { informações de forma linear, } \\
\text { em etapas logicamente } \\
\text { encadeadas. Tiram mais } \\
\text { proveito do material quando } \\
\text { as partes estão logicamente } \\
\text { conectadas, isso facilita o } \\
\text { conhecimento de aspectos } \\
\text { específicos e a solução de }\end{array}$ & $\begin{array}{l}\text { Nos cursos superiores a maioria das disciplinas } \\
\text { são ministradas de forma sequencial. Caso as } \\
\text { etapas não sejam apresentadas, peça detalhes ao } \\
\text { docente publicações onde encontrar os detalhes. } \\
\text { Quando estiver estudando coloque o material em } \\
\text { uma ordem lógica que faça sentido para você. } \\
\text { Prepare resumos. Procure também fortalecer seu } \\
\text { raciocínio global, relacionando cada nova } \\
\text { informação com conhecimentos que você já tem. }\end{array}$ \\
\hline GLOBAL & $\begin{array}{l}\text { problemas. O domínio do } \\
\text { conhecimento se dá por } \\
\text { etapas, que vão sendo } \\
\text { sucessivamente superadas. } \\
\text { Os aprendizes globais } \\
\text { processam as informações } \\
\text { relacionando-as ao contexto } \\
\text { mais amplo. Podem ser } \\
\text { imprecisos sobre os detalhes } \\
\text { da matéria, enquanto não } \\
\text { conseguirem enxergar o } \\
\text { quadro todo, os elementos e } \\
\text { suas relações. }\end{array}$ & $\begin{array}{l}\text { Se você é um aprendiz global, o reconhecimento } \\
\text { de que você percebe e processa as informações } \\
\text { de forma diferente dos seus colegas já começa a } \\
\text { ajudar. Ao ler um material pela primeira vez, } \\
\text { procure entender quais os objetivos pretendidos. } \\
\text { Se tiver uma introdução ou resumo, leia antes. } \\
\text { Sempre procure ter uma ideia completa do } \\
\text { assunto, evite curtos períodos de leitura e ter que } \\
\text { voltar várias vezes. Relacione o assunto com o } \\
\text { que já conhece, com outros domínios, veja as } \\
\text { conexões. No devido tempo você compreenderá } \\
\text { o assunto novo, como por um estalo. }\end{array}$ \\
\hline
\end{tabular}

Figura 4 - Estilos e Estratégias segundo Grupo APRENDER - EESC - USP - Engenharia de Produção

Fonte - Aprende... (2012) 
Assim, ao analisarmos a figura 4, fica mais clara a ideia de que o docente atuando em dimensões de liderança já consolidadas, pode intervir positivamente nos processos de aprendizagem de diferentes formas, conforme o contexto, como por exemplo, com uma Liderança Situacional (SHAHMANDI et al., 2011) conforme os estilos de aprendizagem dos estudantes de engenharia.

\subsection{Mídias Sociais e o Suporte ao trabalho colaborativo}

Embora o conceito de internet estivesse ainda sendo construído, em 1978, o sociólogo Roxanne Hiltze e o cientista da computação Murray Turoff publicaram o artigo Nação em Rede, antevendo uma congruência entre as ciências sociais e a comunicação por intermédio de computadores (WELLMAN, 2004). Nessa mesma época, em 1979, Tom Truscott e Jim Ellis, da Duke University criaram a Usenet, um sistema de discussão que permitiu que usuários conectados por computador pudessem enviar mensagens públicas (KAPLAN; HAENLEIN, 2010). Em 1991, o IBM Notes já permitia o trabalho colaborativo em ambientes virtuais, mas as pesquisas com grupos de pessoas trabalhando nestes ambientes restringiam-se aos laboratórios próximos fisicamente e com pequenos grupos sendo estudados (SPROULL; KIESLER, 1991). No mesmo ano tornou-se público a definição de groupware elaborada por um pesquisador do Departamento de Ciências da Computação da Universidade do Colorado, USA: "Sistemas baseados em computador que apoiam grupos de pessoas engajadas em uma tarefa comum (ou objetivo) e que fornecem uma interface para um ambiente compartilhado" (ELLIS; GIBBS; REIN, 1991, p. 43, tradução livre). Muitas incertezas pairavam no ar e os altos custos de uma experiência mais ampla, com equipes em locais diversos, era fator de descrença no modelo, mesmo após John Perry Barlow, um dos líderes da Electric Frontier Foundation ter escrito, em 1995: 
"Com o desenvolvimento da Internet e com a propagação crescente da comunicação entre computadores em rede, nós estamos em meio ao evento tecnológico mais transformador desde a captura do fogo. Eu costumava pensar que era apenas uma coisa maior desde Gutenberg, mas agora eu acho que esse avanço vai além" (WELLMAN, 2004, p. 3, tradução livre).

Mesmo em meio a uma falta de adesão de pesquisadores e gestores ao modelo proposto para a colaboração de equipes em ambientes virtuais, com o advento da Web 2.0 e o surgimento de ferramentas interativas, assim como novas formas de mobilidade, como os Smarthphones, o trabalho colaborativo em ambientes não presenciais começou a ser disseminado. Novos modelos de negócios brotavam suportados pela flexibilidade e possibilidade de interação trazidas pelas novas ferramentas (CHESBROUGH, 2006). Parece haver confusão entre os gestores, acadêmicos e pesquisadores sobre o que é exatamente Web 2.0, o que deve ser incluído sob este termo, como as Mídias Sociais diferem dos conceitos aparentemente intercambiáveis relacionados a ela e o conteúdo gerado pelo usuário, havendo, portanto, uma necessidade de rever e fornecer informações de onde o termo Mídia Social vêm e o que ele inclui (KAPLAN; HAENLEIN, 2010). Enquanto as aplicações, tais como páginas pessoais, Enciclopédia Britânica Online, e a ideia de publicação de conteúdo pertencem à era da Web 1.0 , elas são substituídas por Blogs, Wikis, projetos colaborativos, comunidades de conteúdo, sites de redes sociais como conhecemos hoje, mundos virtuais de jogos e mundos virtuais sociais na Web 2.0. Isso se dá em 2004, quando pela primeira vez o termo Web 2.0 é citado para descrever um novo modo em que os desenvolvedores de software e usuários finais pelo mundo começaram a utilizar da internet, interagindose (KAPLAN; HAENLEIN, 2010). Os desafios e oportunidades das Mídias Sociais utilizam a World Wide Web (WWW) como uma plataforma pela qual conteúdo e 
aplicativos não são mais criados e publicados por indivíduos, mas são continuamente modificados por todos os utilizadores de forma participativa e colaborativa.

Desse modo, as mídias sociais emergem e coligam-se com as redes sociais, surgidas em 2002, sem ainda a interatividade da WEB 2.0, com o advento do site de relacionamento Friendster, democratizando o acesso e compartilhamento de informações. A evolução dos concorrentes culminou com o advento do Facebook em fevereiro de 2004, que alcança, segundo métricas advindas de sites especializados, como o comScore.com, mais de 1.000.000.000 (um bilhão de usuários) em 2013, e o surgimento do Google+ em 28 de Julho de 2011, definido pelos engenheiros como uma camada social uma vez que integra a maioria dos serviços oferecidos pelo Google socialmente. O Google+ atinge 500.000 .000 (quinhentos milhões de usuários) em Fevereiro de 2013. Ainda, a Web 2.0 introduziu novos conceitos e ferramentas que são capazes de operacionalizar uma visão social mais centrada e não marginalizada (O’REILLY, 2005).

Em relação ao trabalho colaborativo em ambientes virtuais, em suas pesquisas, Brake (2009) identificou o notável crescimento das equipes trabalhando em ambientes virtuais, em lugares diferentes e possibilidades diferentes de tempo. Nesse contexto, ferramentas de groupware passaram a permitir tarefas realizadas em conjunto, em tempo real e em diferentes lugares, alcançando metas com desempenho igual ou superior ao das equipes face a face (ELLIS; GIBBS; REIN, 1991). Nesses ambientes, a percepção da interface amigável facilita a interação entre os membros da equipe e fomentam maior grau e adesão aos projetos (SEGAL, 1994). Ao contrário de equipes trabalhando face a face, em que o grau de percepção do colaborador para com membros da equipe se torna mais plausível, em ambientes 
virtuais de colaboração essas percepções, como discutido anteriormente, podem ser distorcidas, cabendo ao líder possuir as percepções necessárias para a correta condução das atividades.

O conhecimento se torna fator crítico de sucesso não apenas em ambientes presenciais, mas também nos virtuais, uma vez que é entendido como

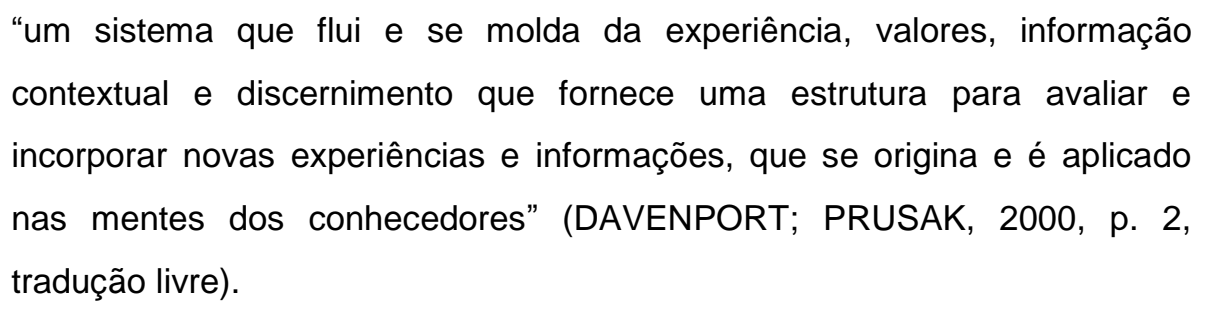
incorporar novas experiências e informações, que se origina e é aplicado nas mentes dos conhecedores" (DAVENPORT; PRUSAK, 2000, p. 2, tradução livre).

É inerente ao docente como líder entender o conhecimento como uma crença verdadeira justificada (NONAKA; TAKEUCHI, 1995) para que o conhecimento das novas tecnologias possa agregar valor ao ensino e este possa se interagir com o mundo virtual de forma proativa, como e-líderes, que somando-se aos ambientes tradicionais de ensino face a face, tornam-se os ambientes híbridos dos tempos atuais, onde os desafiantes métodos de ensino-aprendizagem, como o PBL, são utilizados para disseminação de conhecimentos.

\subsection{O PBL no processo ensino-aprendizagem e a incorporação dos ambientes híbridos}

Na década de 1920, a faculdade de direito da Universidade de Havard, nos Estados Unidos da América, adota um método de ensino apoiada em estudo de casos como forma de instigar o pensamento crítico de seus estudantes frente a problemas do cotidiano enfrentados pela sociedade daquela época (SCHMIDT, 1993). O estágio embrionário do PBL estava lançado e amadureceu na Universidade Case Western Reserve (EUA) nos anos de 1950 por meio de um modelo 
desenvolvido para o ensino de medicina para seus estudantes, que teve sua motivação no sucesso alcançado pelos estudos de caso da Universidade de Havard, e que consolidou-se na escola de medicina da Universidade McMaster (Canadá) no final dos anos 1960 (SAVERY; DUFFY, 1998; BOUND; FELETTI, 1998). Tal busca de um novo modelo de ensino que aperfeiçoasse o processo ensino-aprendizagem surgiu da necessidade de adaptação para com a velocidade das mudanças ocorridas na sociedade frente a estagnação dos processos tradicionais de ensino, que em geral não trazem novas soluções, mas apenas replicam informações ora já presentes nas limitadas fontes de acesso a informações de outrora, como os livros (DOCHY; SEGERS; BUEHL, 1999).

Na década de 1990, a evolução e barateamento dos Hardwares e Softwares, e a disponibilização da internet para parte da população, mesmo que de forma ainda limitada, fez da TIC uma grande aliada da evolução da sociedade. Naquela época a sociedade tornava-se mais complexa, caracterizada pela dinâmica e mutante massa de informações começada a ser gerada pela internet, soluções advindas de produtos multimídias e tecnologia voltada para a educação, onde o mercado de trabalho de rápidas mudanças exigia uma mão de obra mais flexível, dirigida para essa proporção crescente de informações disponíveis, intensivo trabalho em equipes e uma necessidade de geração de novos conhecimentos e ciclos de aprendizagem vitalícios (NONAKA; TAKEUCHI, 1995; QUINN, 1992; TYNJÄLÄ, 1999).

No âmbito da educação, as pesquisas tem mostrado que solucionadores de problemas bem sucedidos possuem uma base de conhecimento extremamente organizada e flexível e dominam as habilidades para aplicar esse conhecimento para resolver problemas não estruturados (CHI; GLASER; REES, 1982). Assim sendo, muitos pesquisadores da área da educação acreditam que os graduados não devem 
se ater apenas a conhecimentos específicos, mas também estejam aptos a aplicar este conhecimento para resolver problemas complexos de uma forma eficiente (ENGEL, 1997, POIKELA; POIKELA, 1997; SEGERS, 1996). A busca da pesquisa em educação visa atingir, entre outros, esse objetivo da capacitação de universitários como exímios solucionadores de problemas e o PBL tem sido pesquisado com a finalidade de obter as melhores práticas para que o conhecimento necessário seja enraizado na mente dos aprendizes (ALBANESE; MITCHELL, 1993; DE CORTE, 1990).

Em relação ao Brasil, Masetto (1996) diz que alguns fragmentos do que viria a ser o PBL foram observados na década de 1930 nos desígnios dos fundadores da Universidade de São Paulo (USP), que em suas soluções para um ensino mais consistente, vislumbraram melhores oportunidades de aprendizagem nos estudantes se os docentes seguissem alguns elementos estratégicos no processo ensinoaprendizagem, tais como:

- Fornecer experiência prática ao estudante desde o inicio dos cursos para que os mesmos pudessem antever os contextos profissionais da realidade das organizações

- Partir para a prática antes do domínio dos requisitos teóricos, estimulando o pensamento crítico e a busca do saber

- A aprendizagem dos temas de forma não fundamentada apenas na lógica, mas de forma sistêmica, saindo da maneira sequencial

- A construção do conhecimento de forma global, não linear

- A delegação aos próprios estudantes de seu desenvolvimento profissional, com disciplina, ética e responsabilidade em relação aos colegas, docentes e a coletividade 
Neste contexto, Ribeiro (2005) argumenta o PBL como um método de ensino essencialmente voltado a resolução de problemas reais, aonde a motivação do estudante viria da busca do conhecimento necessário para a elucidação de questões intrigantes, tendo para isso um universo de informações a serem exploradas sem a limitação de conteúdos pré-formatados.

O PBL tem sido adotado como método de aprendizagem em muitas instituições de ensino superior ao redor do mundo, entretanto, os resultados advindos do método são muito divergentes entre os pesquisadores. Várias escolas recentemente demonstraram a viabilidade da mudança da grade curricular tradicional para o PBL, mas para isso, comumente, alguns anos foram necessários para se alcançar um acordo entre a equipe envolvida no planejamento, desenvolvimento e inicio da implantação (SCHWARTZ; MENNIN; WEBB, 2001). Assim, Vernon e Blake (1993) afirmam, com base em suas pesquisas, que as habilidades adquiridas pelos estudantes expostos ao PBL são superiores aos dos estudantes formados pela grade curricular tradicional. Já Albanese e Mitchell (1993) concluem que é necessária cautela na implantação do método uma vez que, mesmo que muitas pesquisas corroborem essa abordagem, alguns resultados observados em suas pesquisas foram adversos, o que valida Vernon e Blake (1993), que informam que o PBL não se diferenciou dos métodos tradicionais em uma metaanalise sobre o tema por eles conduzida quando a questão de pesquisa era relacionada ao conhecimento adquirido, e não às habilidades. Em outro caso, extensa pesquisa mostrou que os resultados educacionais melhoram quando os estudantes tecem a aprendizagem na prática e compreensão, em vez de memorização, sendo que o sucesso da implantação do PBL está no planejamento e 
na estratégia, sendo muitas das dificuldades advindas do inter-relacionamento pessoal docente-estudante (BEELAND JR., 2002).

O grau de sucesso ou insucesso na utilização pelas IES do PBL como método de ensino remete a análise de algumas vantagens e desvantagens encontradas na literatura para com essa abordagem (MENNIN; MAJOOR, 2002). Como vantagem podemos citar a expertise dos docentes frente aos assuntos por eles tratados em suas disciplinas, o que permite um melhor direcionamento dos estudantes para a aprendizagem dos assuntos mais relevantes. Como desvantagens observa-se as dificuldades na quebra do paradigma tradicional de ensino, com temores advindos da insegurança, tanto por parte dos estudantes como dos docentes, frente ao novo modelo, que sugestiona mudança nas formas de avaliação, dos interrelacionamentos pessoais, da adequação das estruturas físicas das salas de aula e novas formas de se buscar e interpretar as informações, saindo do tradicional modelo sistemático (PARK, 2006; RIBEIRO, 2005; RODRIGUES; FIGUEIREDO, 1996; SCHWARTZ; MENNIN; WEBB, 2001; TARADI et al., 2005).

Com o advento da TIC e WWW, novas formas de se aplicar o PBL foram adotadas, agora com possibilidade de interação estudante-docente também sendo feito pelos ambientes virtuais advindos com a evolução da internet, chamados Webbased learning (WBL), onde resultados muito positivos têm sido observados em relação aos resultados da aprendizagem (RIVERA; MCALISTER, 2001). Taradi et al. (2005) afirma que a WWW, a WBL, o PBL e o aprendizado colaborativo são atualmente as mais poderosas opções de educação no ensino superior e que ao combinar o PBL com um ambiente colaborativo fundamentado pela WBL, programadores podem criar um ambiente de aprendizagem proativo e vibrante, como os jogos de empresas e simulações, que aperfeiçoam o aprendizado do 
estudante. Michel, Bischoff e Jakobs (2002) afirmam que melhores resultados em termos de desempenho e satisfação são alcançados por meio de interações virtuais e que estão associados com a maior motivação e aproveitamento dos estudantes e docentes quando inseridos nestes contextos. Estudantes sendo educados em ambientes híbridos têm à sua disposição uma maior gama de estímulos intelectuais e possibilidades de aprendizagem do que nos métodos tradicionais face a face ou cursos totalmente online (GOULD, 2003), sendo que em várias pesquisas foram encontrados dados muito negativos dos efeitos do ensino somente a distancia nos estudantes (FRIEDMAN; DEEK, 2002), como a insegurança diante da mudança do tradicional, dificuldades no autogerenciamento do tempo necessário aos estudos, dificuldade de interpretação do significado de mensagens subliminares, ou entrelinhas, entre os estudantes e o docente e a falta de oportunidades de elucidações de duvidas mais profundas e intrínsecas, onde a linguagem corporal pode ajudar (RIVERA; MCALISTER, 2001).

A importância do papel do docente no PBL fica clara no momento que o mesmo pode atuar desfazendo as incertezas frente aos diferentes estilos de aprendizagem dos estudantes, estilos que segundo Escrivão Filho e Ribeiro (2007), podem não se adaptar a um ambiente de aprendizagem autodirigida e colaborativa. A importância da liderança do docente emerge, desse modo, no PBL. O líder proativo fomenta e reforça a motivação para o estudante se tornar um aprendiz independente no modelo tradicional, como propõe o PBL (MCKECHIE; BROWN; PINTRICH, 1994), e seu estilo de liderança pode adequar-se a diferentes contextos nos ambientes virtuais, tornando-se esse universo de ensino, o ambiente híbrido, o estado da arte para um aprendizado consolidado (TARADI et al., 2005). Entretanto, para atingir-se tal nível de interconectividade estudante-docente muitos são os 
desafios do PBL em ambientes híbridos, como os fatores culturais e estruturais, que se resumem na resistência para com a mudança do paradigma atual de ensino.

Atentar-se à estratégia nos ambientes híbridos de aprendizagem, onde se combinam as tradicionais instruções Face a Face com tecnologias advindas da Internet, com potencial de fundir o melhor destas experiências (SWENSON; EVANS, 2003), tonar-se um fator crítico de sucesso. A pontual afirmação de Gil (2005, p. 69) de que "os estudantes estão tão acostumados a aulas expositivas no sentido clássico, que tendem a rejeitar inovações propostas pelo docente, mantendo uma atitude de passividade e desligamento" já fornece elementos que vislumbram a complexidade do sistema, provendo ao docente a necessidade de uma percepção da importância de uma visão holística dos ambientes, o que a inteligência emocional pode proporcionar-Ihe (PURVANOVA, 2009).

Na implantação do PBL sete passos sistemáticos são sugeridos por lochida (2001), Park (2006) e Sakai e Lima (1996), focando o estudo auto-dirigido, que são:

1) Elucidar os termos difíceis ou desconhecidos. Momento: a ser realizado no primeiro encontro das equipes com o docente

2) Listar os problemas. Momento: Primeiro encontro

3) Discussão dos problemas (brainstorming). Momento: Primeiro encontro

4) Sintetizar os problemas. Momento: Primeiro encontro

5) Formulação dos objetivos de aprendizado. Momento: Primeiro encontro

6) Procura de informações - Momento: atividades extraclasse na busca de dados e informações entre uma aula e outra

7) Reagrupamento da equipe, integração das informações e resolução do caso: Momento: Próximo encontro presencial 
Não obstante ao método sistemático de implantação, é fundamental entender que cada IES e, mesmo cada docente, pode ter uma forma diferenciada de conduzir o processo de implantação do método de ensino PBL, e quando ambientes híbridos são inseridos no contexto, o docente passa a ser o pilar de sustentação para o sucesso da empreitada, assim como o elo integrador entre os estudantes e os resultados, no momento que atua como facilitador dos processos (TARADI et al., 2005). A incorporação pelo docente de estilos de liderança adequados a cada contexto permite que seu papel enquanto facilitador seja desempenhado de forma a alcançar um ótimo global, advindo das inter-relações das partes inseridas na complexidade do sistema: estudante-ambiente-docente.

\section{Síntese dos temas tratados}

A fase de implantação do PBL em disciplinas de graduação e pós-graduação, tendo ambientes híbridos de aprendizagem como a interface entre os estudantes e o docente em uma IES, demanda do docente uma visão holística para com os contextos de cada disciplina, onde elementos heterogêneos se relacionam, originando comportamentos coletivos.

Para uma correta análise de cada contexto, e dos comportamentos de seus elementos, é válido ao docente aprofundar-se no entendimento da inteligência emocional, que fornece meios para o alcance de determinados fins, como por exemplo, interpretar as nuances que acompanham os estudantes nos processos inerentes ao ensino, pelo entendimento de suas complexidades mais intrínsecas, como emoções e visões de mundo. O estudo dos Sistemas Complexos Adaptativos, e sua atuação nos contextos organizacionais, fornece ao docente informações de 
como os elementos de um sistema, nesse caso os estudantes e a tecnologia, se relacionam, e como esse relacionamento entre eles originam comportamentos coletivos, e como esse sistema interage com o ambiente, por meio de feedbacks.

Com essa visão concatenada com o domínio dos processos de transferência e retenção do conhecimento, e também dos perfis de aprendizagem que os estudantes possuem, assim como os elementos motivacionais que os movem, ou bloqueiam, o docente se apossa de condições mais apropriadas para atuar de uma forma mais abrangente em ambientes híbridos de aprendizagem, onde a TIC está amplamente disseminada. Também permite ao docente traçar estratégias mais eficientes para que o paradigma atual de ensino, que muitas vezes se mostra engessado e alicerçado na disseminação aos estudantes mais de informações do que de conhecimentos, devido a apoiar-se muitas vezes em conteúdos préformatados, passe a um novo paradigma, onde os estudantes tornam-se responsáveis pela construção do próprio aprendizado. Esse novo paradigma pode se consolidar por meio do PBL, mas a mudança exige um esforço salutar, e para que ela possa acontecer de fato, a liderança necessária do docente mostra-se como o elo de ligação para que a motivação seja gerada nos estudantes, e um novo patamar, mais eficiente, no processo ensino-aprendizagem, seja alcançado no momento que um aprendizado mais efetivo seja adquirido pelos estudantes. 


\section{MÉTODO DE PESQUISA}

Este capítulo objetiva definir o método que será empregado na pesquisa e quais ferramentas serão usadas na condução e análise dos resultados.

\subsection{Caracterização da pesquisa}

Para prover a realização da pesquisa utilizou-se o estudo de caso múltiplo, holístico e qualitativo, de natureza empírica (YIN, 2001). Um estudo de caso referese a uma análise intensiva de uma situação particular (TULL; HAWKINS, 1996) tendo em sua essência tentar esclarecer uma decisão ou um conjunto de decisões, o motivo pelo qual foram tomadas, como foram implementadas e com quais resultados (SCHRAMM, 1971). Os estudos de caso representam a estratégia preferida quando

- Se colocam questões do tipo "como" e "por que"

- Pesquisador tem pouco controle sobre os eventos

- O foco se encontra em fenômenos contemporâneos inseridos em algum contexto da vida real

A clara necessidade pelos estudos de caso surge do desejo de se compreender fenômenos sociais complexos. O estudo de caso permite uma investigação para se preservar as características holísticas e significativas dos eventos da vida real. Questões como e por que estimulam o uso de estudos de caso, experimentos ou pesquisas históricas.

A pesquisa se classifica como exploratória que, segundo GIL (1999), é mais adequada para ser realizada quando se detém pouca informação sobre o fenômeno em análise, e descritiva, que segundo Malhotra (2001, p. 108), "[...] tem como 
principal objetivo a descrição de algo, um evento, um fenômeno ou um fato [...]".

O estudo de caso caracteriza-se também pelo caráter qualitativo. Gil (2005) explica que a pesquisa qualitativa, por apresentar caráter exploratório, incita os entrevistados a refletirem livremente sobre algum assunto, objeto ou conceito, indicando aspectos subjetivos e percepções advindas de motivações não explícitas, ou mesmo conscientes, de maneira espontânea, permitindo ao pesquisador desenvolver conceitos, ideias e entendimentos a partir de padrões encontrados nos dados, ao invés de colher dados para comprovar teorias, hipóteses e modelos préconcebidos.

O pesquisador almeja com esse instrumento elucidar as informações relacionadas a seu objetivo.

\subsection{Técnicas de coleta de dados}

Foi utilizada a entrevista em profundidade, que Fontana e Frey (1994) afirmam que é uma das mais comuns e importantes formas que empregamos para tentar entender nossa condição humana. A entrevista em profundidade é muito útil para estudos do tipo exploratório, que tratam de conceitos, percepções ou visões para expandir conceitos sobre a situação analisada (SELLTIZ; WHRIGHTSMAN; COOK, 1987). Na pesquisa qualitativa a entrevista demonstra-se um instrumento importante por permitir a geração de conteúdos fornecidos diretamente pelos elementos envolvidos no processo, que podem ser tanto objetivos quanto subjetivos. Assim sendo, a entrevista como fonte geradora de informações pode prover dados primários e secundários, e ser estruturada de diversas e variadas maneiras, tais como a pesquisa da opinião do entrevistado com questionário fechado, a entrevista 
semiestruturada, a entrevista aberta, a entrevista não diretiva, a entrevista centrada (MINAYO, 1996).

Neste trabalho, também foram utilizados questionários com questões abertas e fechadas para coletar a opinião dos estudantes por meio de seus discursos escritos. O questionário é uma ferramenta de investigação que visa coletar informações baseando-se, geralmente, na investigação de um grupo representativo da população em estudo. Para tal, coloca-se uma série de questões que abranjam um tema de interesse para os pesquisadores, podendo ou não existir interação direta entre estes e os pesquisados (GIL, 1999). O questionário é muito útil quando um pesquisador pretende coletar informações sobre um determinado tema. Assim sendo, por meio da aplicação de um questionário a um público-alvo constituído, por exemplo, de estudantes, é possível recolher informações que permitam conhecer melhor as suas lacunas, bem como melhorar os métodos de ensino, podendo, deste modo, individualizar-se o processo ensino-aprendizagem quando necessário.

A importância dos questionários se deve também pela facilidade com que se questiona um elevado número de pessoas, num espaço de tempo relativamente curto, podendo ser de natureza social, econômica, familiar, profissional, relativos a opiniões próprias, à atitudes em relação a escolhas ou a questões humanas e sociais, às suas perspectivas, ao seu nível de conhecimentos ou de consciência de um evento ou de um problema (DESHAIES, 1992). 


\subsection{Técnicas de análise de dados}

Observação e análise dos gráficos advindos das Planilhas Excel, na forma de pizza e barras, para obtenção de uma amostragem visual do resultado final. Os gráficos são excelentes para a exibição de pontos de dados como porcentagens de um todo.

Utilizou-se também a análise do discurso escrito, que é entendido como um método que aspira não somente aprender como uma mensagem é comunicada, mas também estudar o seu sentido avaliando-se quem remeteu a mensagem, quem a acolheu e qual o contexto na qual está inserida (VERGARA, 2005). Uma das condições imprescindíveis para que a análise do discurso seja realizada com clareza é a análise por meio de sua totalidade, na íntegra, sem cortes, correções ou interpretações iniciais. Vergara (2005) recomenda que o documento final, subsequente à análise, deva conter trechos do material analisado, no sentido de certificar a fiel interpretação do pesquisador.

\subsection{Universo da pesquisa}

Estudantes do curso de graduação e pós-graduação do Departamento de Engenharia de Produção da Escola de Engenharia de São Carlos da Universidade de São Paulo.

\subsection{Procedimentos metodológicos}

Participaram da pesquisa nos anos de 2011 a 2012 um total de 197 estudantes, sendo 92 (noventa e dois) estudantes do $2^{\circ}$ ano da disciplina de 
Sistemas de Informação (67 homens e 25 mulheres), 85 (oitenta e cinco estudantes) da disciplina de Sistemas de Apoio a Decisão do $4^{\circ}$ ano (61 homens e 24 mulheres) e 20 (vinte) estudantes da pós-graduação stricto-senso da disciplina de Sistemas de Apoio à Decisão (11 homens e 9 mulheres) onde foi proporcionada a oportunidade de se interagirem por meio de ambientes virtuais como o Wiggio, Twitter, Moodle, Facebook e Google+, cuja as mídias sociais presentes nesses ambientes foram exploradas no trabalho em equipe na realização das tarefas delegadas em sala de aula presencialmente, fundamentadas no método de ensino PBL, onde o elemento central do aprendizado é o estudante, que é exposto a situações motivadoras e que, por meio dos problemas, é levado a especificar objetivos de aprendizado cognitivo sobre os temas conforme os assuntos tratados (BERBEL, 1988).

As problematizações inerentes aos assuntos necessários aos processos de aprendizagem por descoberta se contrapõem aos de recepção (em que os conteúdos são apresentados ao estudante em sua forma final), induzindo o estudante a reorganizar o material, adaptando-o à sua estrutura cognitiva prévia, para que o mesmo possa desvendar relações, leis ou conceitos que necessitará assimilar para adquirir o conhecimento (CYRINO; TORALLES-PEREIRA, 2004). Foi solicitado pelo docente, o mesmo para todas as disciplinas, que os resultados semanais dos trabalhos propostos de acordo com os temas distribuídos para os grupos trabalharem em busca de soluções, fossem postados no Moodle por meio de anexo, ou nas Wikis do Moodle na forma de texto, para facilitar a avaliação dos estudantes e grupos pelo mesmo, permitindo também ao pesquisador analisar fatores motivacionais que acompanhavam a entrega, ou não, das tarefas, e com qual qualidade e facilidade elas eram resolvidas. 
Os trabalhos desenvolvidos durante a semana nos ambientes virtuais propostos eram também orientados pelo docente pelo método PBL, e os resultados alcançados pelos grupos com base nos argumentos levantados pelo docente nas exposições presenciais, eram apresentados pelos mesmos na aula presencial seguinte aos desafios propostos (em média dois grupos por aula apresentavam em seus avanços em relação à elucidação dos problemas). A interação virtual das equipes durante a semana, com os dados e informações tratados por elas, eram observados pelo docente e o pesquisador, também inseridos nos ambientes virtuais, que procuravam nas inter-relações dos membros, a forma como o conhecimento individual e de grupo era criado ou adquirido. Seguido a apresentação de um grupo, os outros grupos eram convidados a fazerem observações e questionamentos, identificando relações com seus próprios trabalhos, levantando dúvidas e gerando debates, que ao final destes eram complementados pelas observações do docente.

Assim, o fenômeno da liderança por parte do docente em sala de aula presencial foi observado pelo pesquisador durante os semestres pela participação nas aulas presenciais e nos ambientes virtuais. Ao final das disciplinas dos anos de 2011 e 2012, foi aplicado um questionário (Apêndices de 1 a 5) com a concordância dos estudantes, sendo os resultados analisados pelo discurso escrito pelos mesmos, por gráficos de barras e por figuras advindas de gráficos de pizza obtidos pelos Itens Likert (BROWN, 2000) de 5 (cinco) níveis de resposta cada qual com uma cor diferente, de Concordo plenamente a Discordo plenamente, onde cada porcentagem do gráfico continha uma numeração a esquerda demonstrando a quantidade de estudantes que optaram por aquela alternativa e à direita a respectiva porcentagem. A legenda para identificação dos estudantes em seus discursos foi assim elaborada: 
1) Ano que a disciplina foi ministrada

2) Abreviação da disciplina. Ex: $S I=$ Estudantes do $2^{\circ}$ ano da disciplina de Sistemas de Informação; SAD = Estudantes do $4^{\circ}$ ano da disciplina de Sistemas de Apoio a Decisão; SAD_Pós = Estudantes da disciplina de Sistemas de Apoio a Decisão da Pós-graduação

3) Grupo

4) Estudante

Ex: 2011_SI_G01_Alun01 = Ano de 2011, Disciplina Sistemas de Informação do $2^{\circ}$ ano, Grupo 01, Estudante 01.

As observações do pesquisador nos ambientes híbridos de aprendizagem, e a análise dos resultados, sempre visaram criar um link para com o referencial teórico da pesquisa, onde os temas revistos procuraram alinhar-se à pergunta norteadora e ao objetivo. As ações ou ausências do docente nos ambientes híbridos de aprendizagem foram analisadas pela geração de um estímulo positivo ou negativo nos estudantes.

A presença do pesquisador junto aos estudantes, de forma rotativa em suas bancadas, permitiu observar, pela interação para com estes, como o sistema se comportava frente às ações proativas ou reativas do docente. Os temas tratados no referencial teórico se mostravam preponderantes nas observações dos fenômenos em aula, ou nos ambientes virtuais, permitindo a obtenção de uma conclusão clara relativa ao problema de pesquisa. 


\section{RESULTADOS E DISCUSSÃO}

Foram coletadas 556 (quinhentos e cinquenta e seis) páginas de dados nos anos de 2011 e 2012 que, depois de tratados e analisados pelo pesquisador, forneceram informações para identificar características do estilo de liderança empregado pelo docente e o índice de motivação dos estudantes no contexto do PBL, ambientes híbridos e TIC. Em um primeiro momento foi analisado e discutido o Índice de Satisfação do Grupo (Item 4.1), seguido pelo estilo de liderança do docente identificado nos ambientes híbridos na condução da disciplina (Item 4.2) e por último a análise da utilização das mídias sociais pelos estudantes (Item 4.3).

\subsection{Análise do Índice de Satisfação do Grupo}

A Análise do Índice de Satisfação do Grupo (MASON; GRIFFIN, 2002), Subquestões de 1.2 a 1.12 (Apêndice 1) foi possível pela interpretação dos itens da Escala de Likert, (AHIRE, 1996; BADRI, 1995; SARAPH et al., 1989; TAMIMI, 1995; TERZIOVSKI, 1999) elaborados com a intenção de entender às percepções dos estudantes em relação às interações entre seus membros na busca do cumprimento dos desafios das ementas das disciplinas nos anos de 2011 e 2012. Os itens da escala de satisfação dos grupos de trabalho observados no apêndice 1 foram projetados para avaliar a satisfação do grupo com as tarefas em si, a satisfação com os processos do grupo, a satisfação com as recompensas e a satisfação com as condições de trabalho, tendo como finalidade comparar posteriormente os resultados para com a análise do perfil de liderança apontado pelos estudantes em relação ao docente da disciplina (Item 4.2) pela questão 2 do questionário (Apêndice 2) seguida pela análise do emprego das mídias sociais (Item 4.3), questão 3 do 
questionário (Apêndice 3). Todos os itens foram formulados utilizando o grupo como referencia. As instruções para o preenchimento da escala solicitou aos entrevistados a avaliação de cada item com base no que eles pensavam em relação ao nível de concordância de seu grupo como um todo, e não percepções individuais. Esta instrução foi destinada a garantir que os participantes focassem em atitudes do grupo, em vez de atitudes individuais. Os resultados observados nas figuras representam a somatória da análise do índice de satisfação do grupo dos anos 2011 e 2012, com exceção da análise da utilização das mídias sociais, que em 2011 foi focada no Google+ e Moodle e no ano de 2012 no Facebook e Moodle. Uma vez que não foi necessário uma análise ano a ano pelo fato de os resultados obtidos em cada um deles serem muito semelhantes, assim como o modo de conduzir as disciplinas por parte do docente. Variáveis moderadoras não foram pesquisadas uma vez que não houve interferências do docente nos acontecendo no decorrer das pesquisas.

\subsubsection{Itens de análise para obtenção do Índice de Satisfação do Grupo}

Questão 1 do questionário (Apêndice 1) - "Minha percepção individual em relação à minha equipe no cumprimento dos desafios da disciplina" e Sub-questões de 1 a 12.

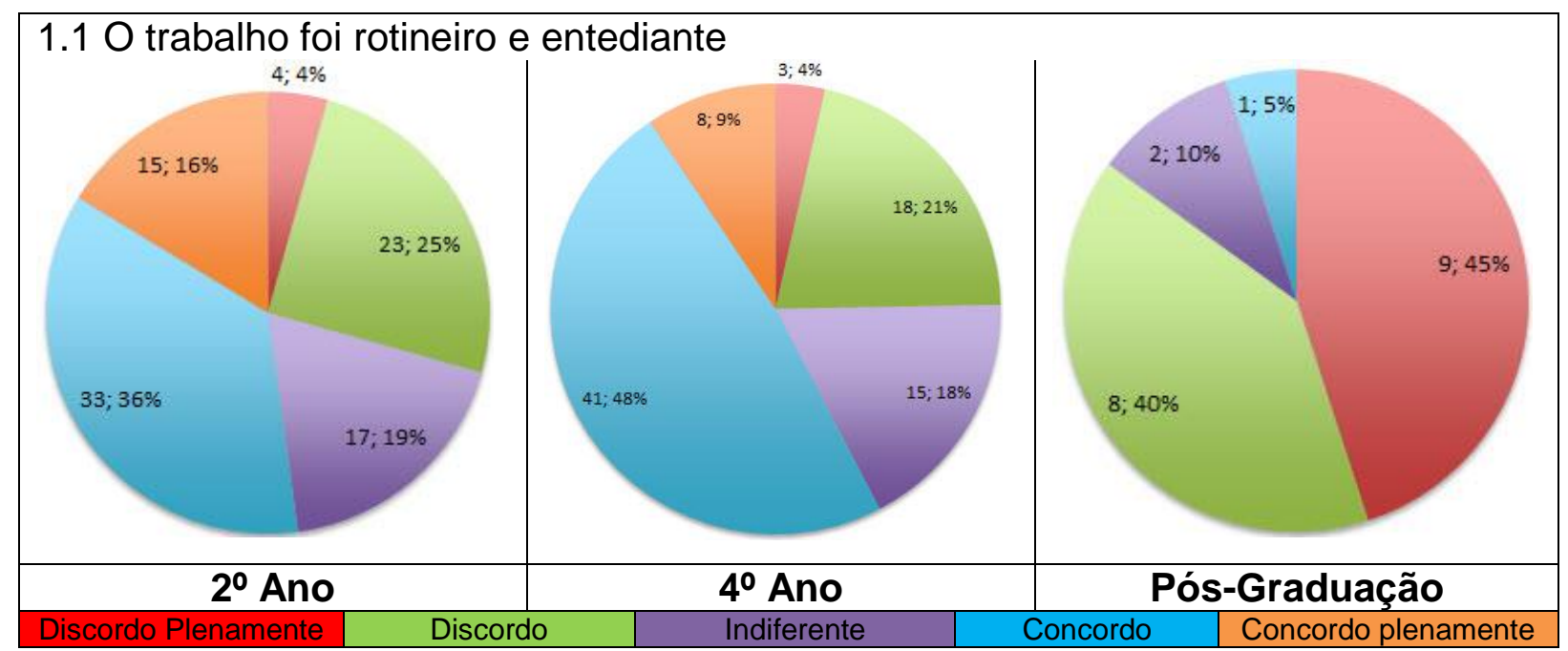

Figura 5 - Análise do índice de satisfação de grupo em relação às tarefas em si, como rotina e motivação 
Observa-se que pelo índice de porcentagem verificado pela somatória das variações da escala de Likert concordância plena e a concordância simples em relação ao subitem 1.1, partindo dos estudantes do $2^{\circ}$ ano com $52 \%$, passando pelos estudantes do $4^{\circ}$ ano $(57 \%)$ e finalizando com os estudantes da pósgraduação (5\%), que o trabalho entre os membros das equipes no cumprimento dos desafios mostrou-se rotineiro e entediante entre a maioria dos estudantes dos $2^{\circ} \mathrm{e}$ $4^{\circ}$ anos, sugerindo a ausência de elementos motivadores nos ambientes híbridos, com exceção dos estudantes da pós-graduação, que demonstraram uma maior capacidade de identificarem os objetivos, talvez pela experiência na assimilação e capacidade de retenção do conhecimento conforme visto pela figura 3 na comparação do processo de aprendizagem entre inexperientes e especialistas (experientes). Há de se convir nessa sub-questão 1.1 que problemas de comunicação e de liderança por parte dos monitores e o docente, visivelmente apontados como fatores negativos na análise do discurso dos estudantes do $2^{\circ}$ e $4^{\circ}$ anos, como poderemos analisar adiante nas sub-questões 1.4 e 1.5, contribuíram para o apontamento da rotina como fomentadora do tédio e consequente desmotivação. Não podemos deixar de analisar que mesmo aparecendo com um menor índice de porcentagem, a somatória entre a discordância plena e a discordância simples de que o trabalho apresentou-se rotineiro e entediante, com $20 \%$ dos estudantes do $2^{\circ}$ ano e $13 \%$ dos estudantes do $4^{\circ}$ ano apontando essa realidade, demonstra a complexidade dentro dos grupos, com visões heterogenias de uma mesma questão, com exceção dos estudantes da pós-graduação, que mostraram-se mais alinhados na busca das respostas aos problemas de pesquisa em cada etapa do método. Cabe verificar que a variante da Escala de Likert indiferente ( $19 \%$ entre os estudantes do $2^{\circ}$ ano e $18 \%$ dos estudantes do $4^{\circ}$ ano), 
demonstrou ao pesquisador que os estudantes que dela optaram foram os dos grupos menos comprometidos com a disciplina de acordo com a avaliação final por meio de nota e observações de seus comportamentos nos ambientes híbridos.

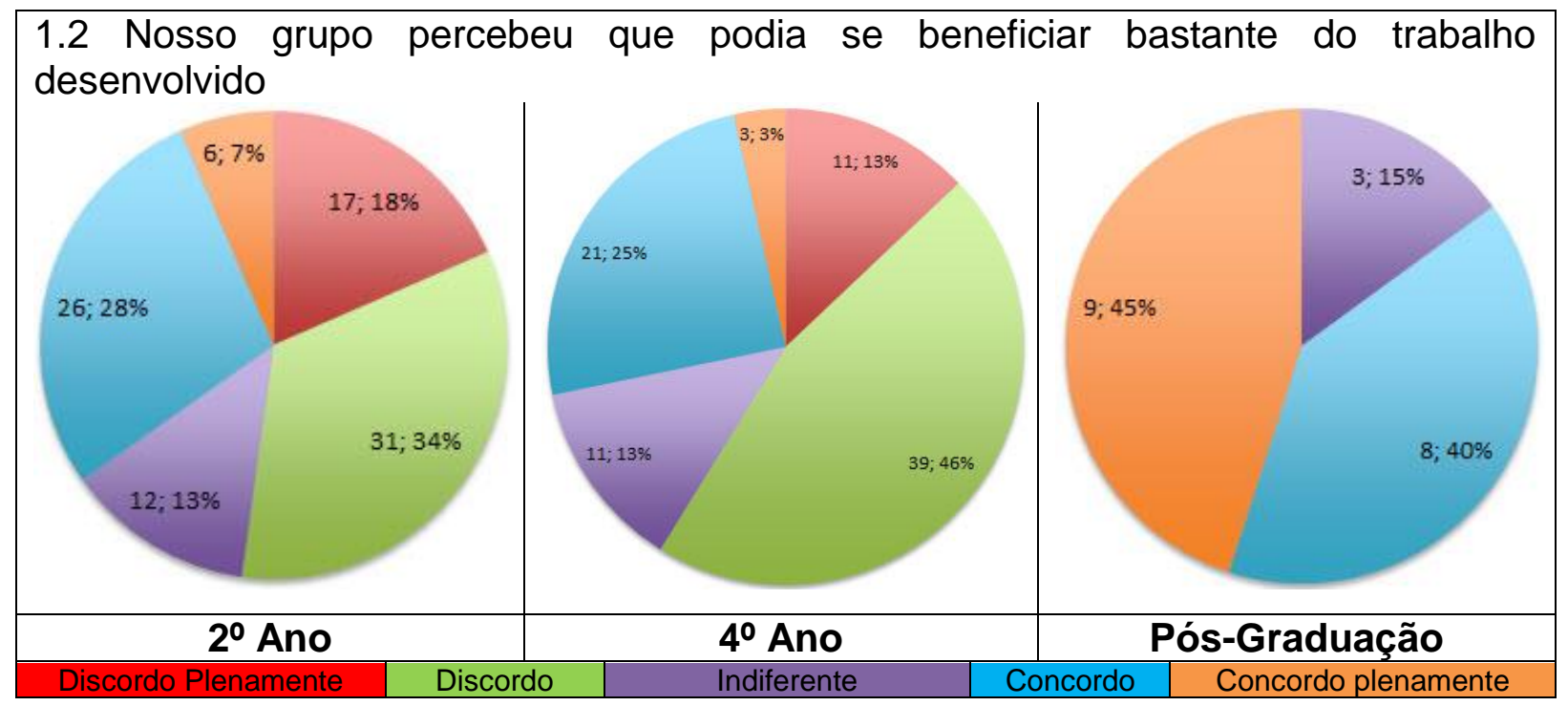

Figura 6 - Análise do índice de satisfação de grupo quanto ao benefício do trabalho desenvolvido

$\mathrm{Na}$ análise do subitem 1.2 da Questão 1, o trabalho desenvolvido pelos membros dos grupos não gerou coesão nas equipes na visão da disciplina como um todo, com $52 \%$ dos estudantes do $2^{\circ}$ ano e $59 \%$ dos estudantes do $4^{\circ}$ ano discordando da afirmativa, contrastando com os $85 \%$ dos estudantes da pósgraduação, que concordaram, o que remete novamente à complexidade do sistema e a necessidade de identificação do perfil de aprendizagem de cada turma. O que se está analisando nesse momento é a interação entre os membros da equipe em relação à disciplina após seu término. É fato afirmar a importância dos relacionamentos interpessoais estudantes-docente uma vez que foi verificado descontentamento em relação ao método de ensino em aula (o $\mathrm{PBL}$ ) no decorrer das disciplinas. Houve dispersão nas turmas de graduação e os momentos 
transcorridos juntos na realização das atividades não superaram as dificuldades encontradas durante o transcorrer das disciplinas.

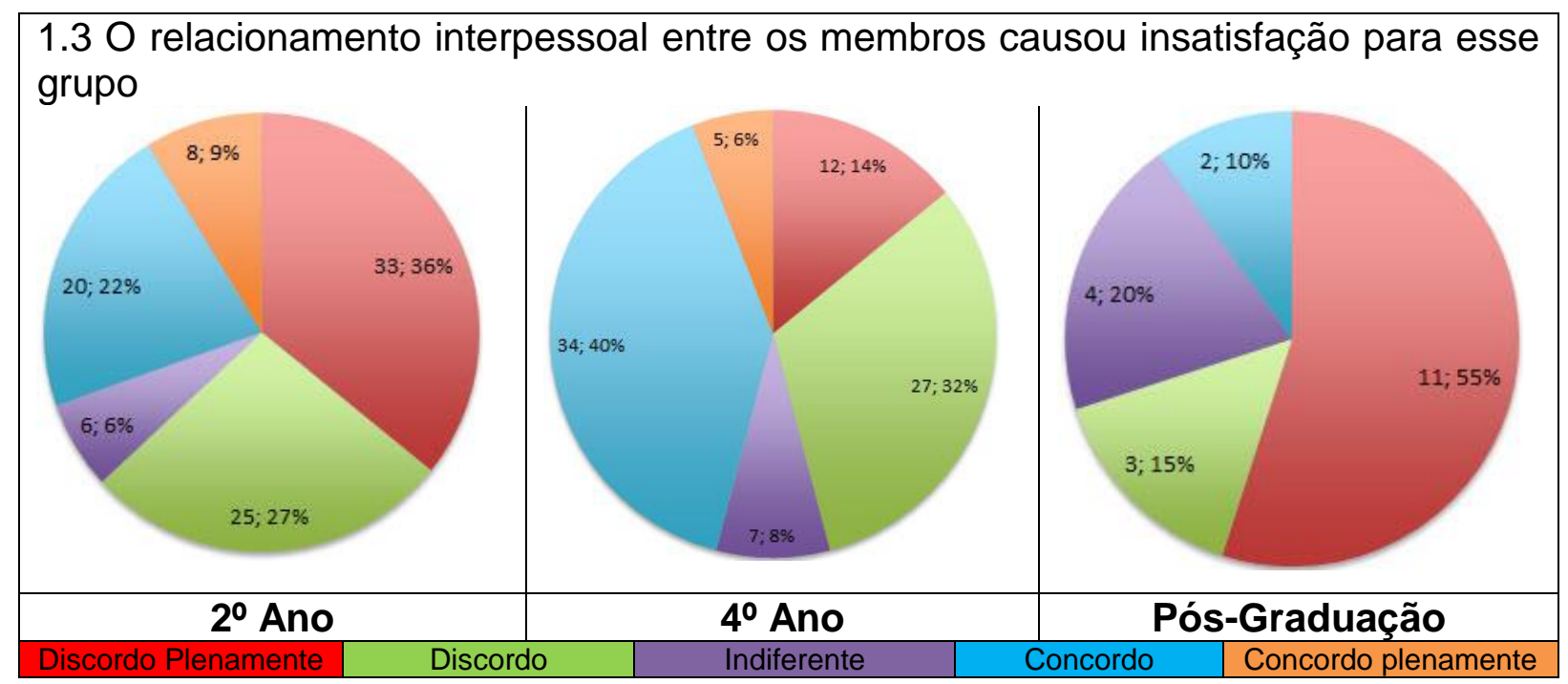

Figura 7 - Análise do índice de satisfação de grupo em relação ao relacionamento interpessoal

Fica nítida pela Figura 7 que o relacionamento interpessoal entre os membros dos grupos em sua maioria não foi afetado por problemas internos ou externos ao trabalho das equipes, como os problemas relacionados ao PBL e o perfil de liderança do docente. A cordialidade e a possibilidade de se fazer amigos mostra-se um importante fator motivacional, tornando-se a aprendizagem mais prazerosa, conforme dito por estudantes da pós-graduação:

...Me surpreendi com alguns aspectos (positivamente). Clima muito cordial de todos. Creio ter amigos de longa duração...(2011_SAD_PósG03_Alun01).

Apenas agradecer e deixar registro do quão foi prazerosa esta experiência na USP (2011_SAD_PósG01_Alun03).

Não obstante, $31 \%$ dos estudantes do $2^{\circ}$ ano e $46 \%$ dos estudantes do $4^{\circ}$ ano demonstraram pela análise da figura 7 que houveram problemas de relacionamento 
entre membros do grupo, problema o qual por uma visão sistêmica do docente como líder nos ambientes híbridos poderia ter sido combatido por uma atitude como Líder Transformacional na dimensão da atuação individual, mas que a complexidade do sistema, como a utilização do PBL, dificultou. O relacionamento interpessoal entre os membros das equipes mostra-se um fator crítico de sucesso em sala de aula na medida em que problemas oriundos dele devem ser observados e combatidos pelo docente como líder, a tempo de serem solucionados antes que se tornem incontroláveis.

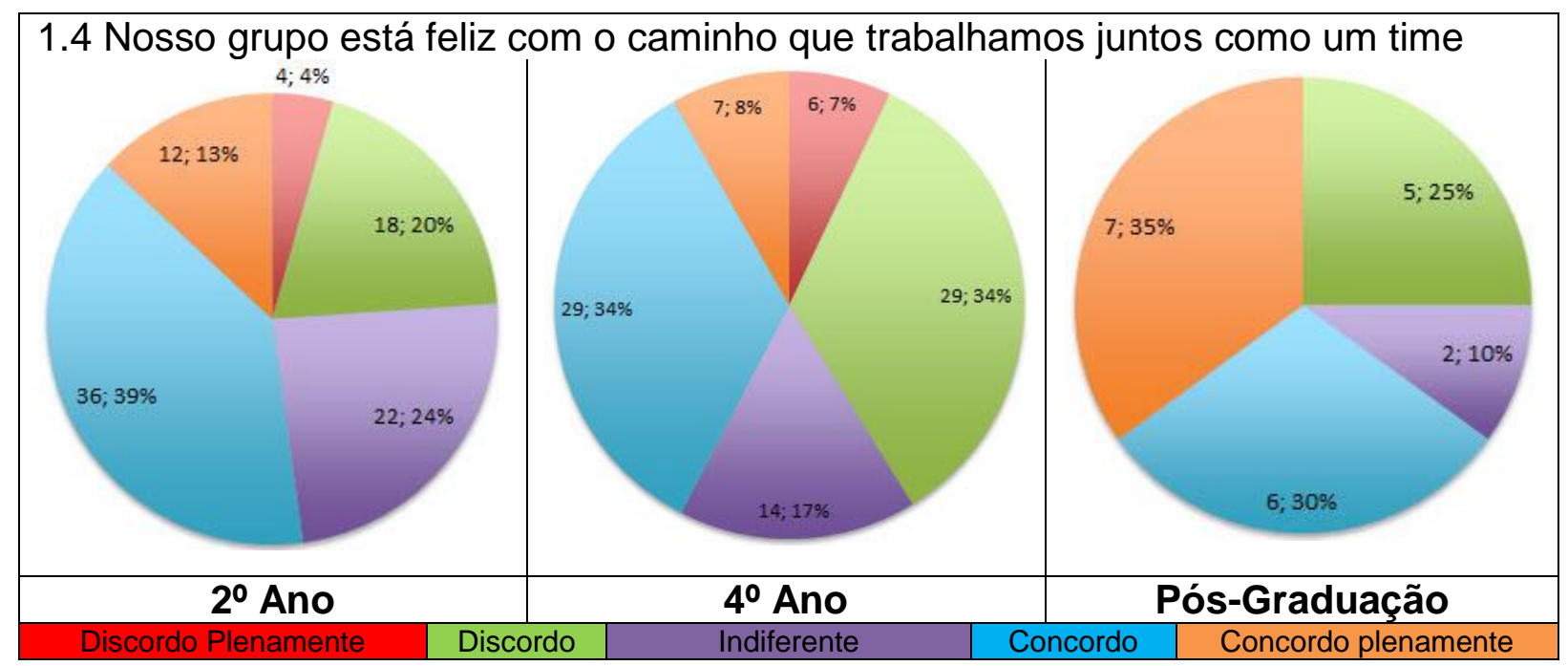

Figura 8 - Análise do índice de satisfação de grupo em relação ao trabalho em equipe

A Figura 8 demonstra pela observância dos gráficos referentes aos estudantes do $2^{\circ}$ ano e pós-graduação, que não houve uma grande divisão das classes em relação à satisfação em se trabalhar em equipe, mas também fica notória a importância de uma visão holística dos acontecimentos em sala de aula por parte do docente, mesmo para com estudantes mais experientes, como os da pósgraduação. O discurso de um membro da equipe da pós-graduação apontou essa questão, o que releva novamente a necessidade da atuação do docente como líder na observância de questões intrínsecas a cada grupo, para a obtenção de um ótimo 
global. Atuando como Líder Transacional na dimensão exceção-ativa possibilita ao docente realinhar a estratégia e o pensamento do grupo, e assim aumentar a motivação do mesmo no decorrer do semestre, uma vez que essa dimensão de liderança permite ao líder identificar problemas antes que os mesmos se cronifiquem.

Gostei da disciplina, porém acho que a sintonia do grupo teve influência, assim como a qualidade das contribuições individuais (2011_SAD_PósG02_Alun02).

Não basta apenas uma boa ideia, é necessário manifestá-la pela externalização do pensamento do grupo e a construção do trabalho. Foi verificado que a falta de sintonia entre os membros dessa equipe do estudante 2011_SAD_PósG02_Alun02 gerou desmotivação, o que poderia ter sido evitado se houvesse a percepção pontual dos problemas ocorridos por parte do docente como líder. Importante frisar que $41 \%$ dos estudantes do $4^{\circ}$ ano discordam que houve um trabalho em equipe que agregasse valor ao grupo, enquanto $42 \%$ concordam. Esse cenário complexo demonstra que metade dos estudantes do $4^{\circ}$ ano não ficaram satisfeitos com o trabalho em equipe, fato que, se fosse identificado pelo docente, e os porquês, poderia ter sido revertido por meio de micro intervenções proativas (SPRINGER; STANNE; DONOVAN, 1999). Essa identificação poderia ter sido feita por meio de uma atuação mais presente frente aos grupos, percorrendo as bancadas, ouvindo as discussões e analisando como o conhecimento estava sendo criado ou adquirido. Como a motivação dos colaboradores é um dos cernes do sucesso de qualquer empreitada que o ser humano possa se empenhar, a falta dela 
é responsável pela não obtenção dos resultados requeridos pelo líder de um projeto, como o docente em uma disciplina.

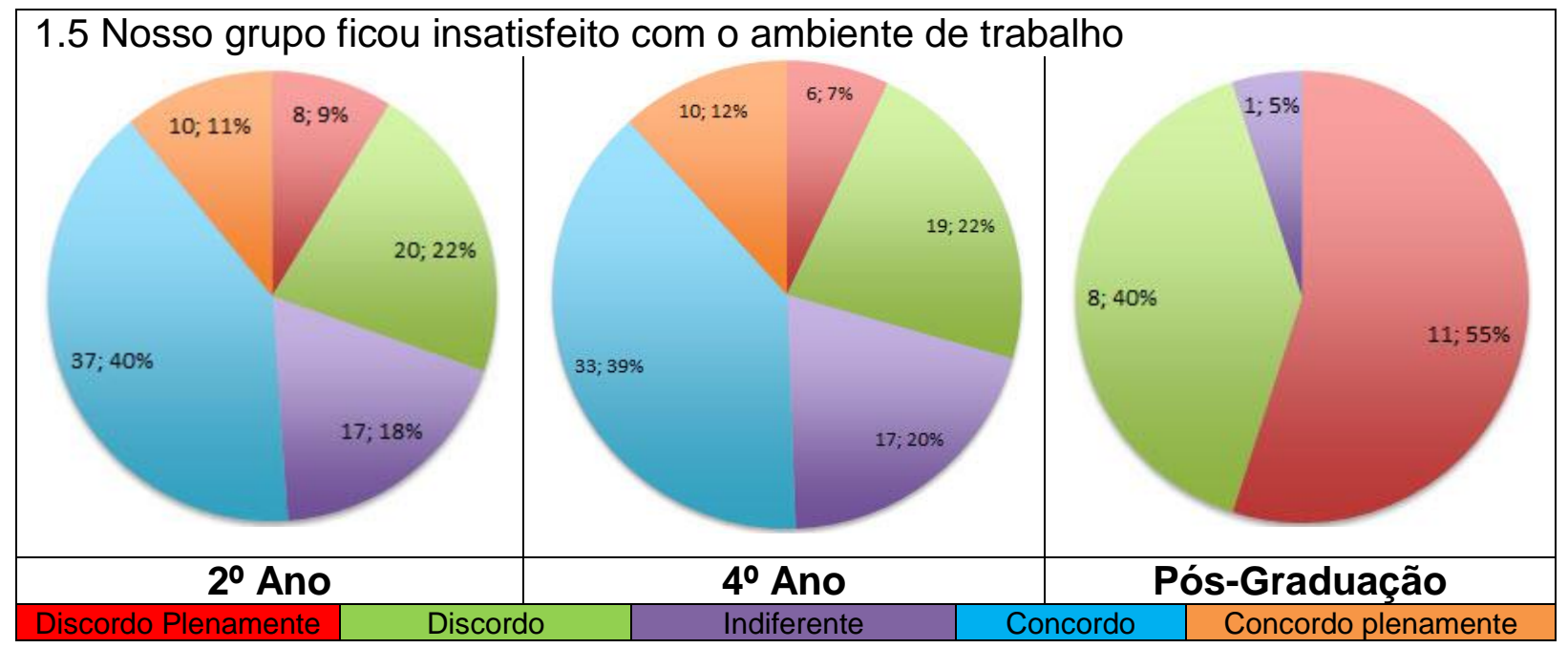

Figura 9 - Análise do índice de satisfação de grupo em relação ao ambiente de trabalho

A insatisfação por parte da maioria dos estudantes do $2^{\circ}$ e $4^{\circ}$ anos em relação ao ambiente de trabalho verificado na Figura 9 demonstra a problemática em sala de aula quando se deseja descontruir o modelo de ensino tradicional, voltado ao conteúdo, apostando-se no método PBL em ambientes híbridos, que vislumbra a construção do conhecimento por meio do pensamento crítico. Como já dito anteriormente, estudantes da pós-graduação, mais experientes em relação aos desafios em sala de aula, mostraram-se satisfeitos com o ambiente de trabalho. Uma visão holística por parte do docente como líder em verificar essa disparidade pode contribuir para a estratégia de aula, diferenciando a mesma de acordo com o grau de maturidade dos estudantes, e os diferentes perfis de aprendizagem. As equipes das disciplinas da graduação não se mostraram preparadas para os desafios na medida em que pelas observações feitas pelo pesquisador, uma mudança radical na maneira de conduzir a aula, aplicando-se o método PBL sem a 
preparação adequada dos estudantes para tal, pode reverter em desmotivação para com o ambiente de trabalho.

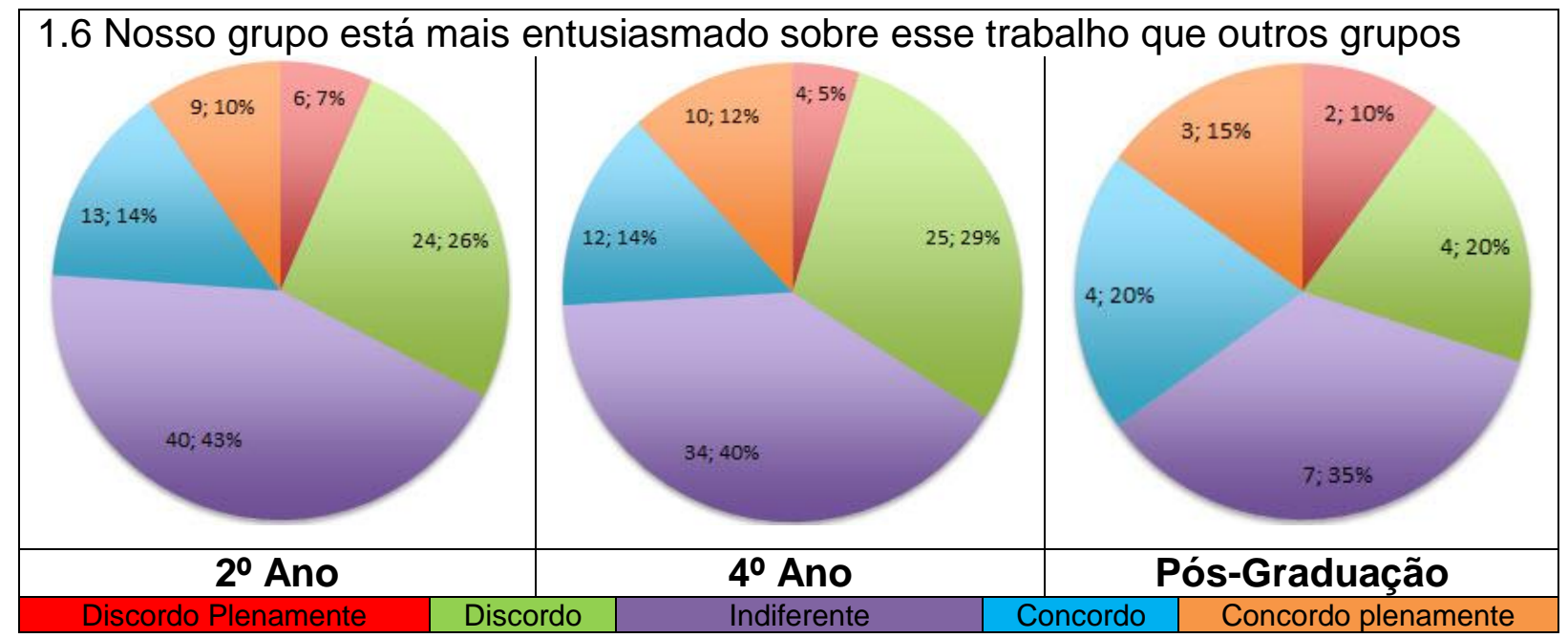

Figura 10 - Análise do índice de satisfação de grupo comparado a outros grupos em sala

A Figura 10 demonstra que a porcentagem equiparada entre as disciplinas em relação à variante indiferente da escala Likert aponta que, acima da preocupação dos grupos quanto ao desempenho dos outros grupos, o foco nos desafios de suas próprias equipes é fator importante na visão dos estudantes, o que, por um lado é admirável, pois fomenta a concentração frente aos desafios do grupo fechado, mas por outro lado pode alienar a equipe, fazendo com que a mesma perca a oportunidade de vislumbrar o progresso de outros times, o que pode ser fundamental no sucesso na resolução de problemas em um mundo real, onde empresas competem por nichos de mercado. Uma vez priorizando o desempenho de suas equipes os líderes das mesmas podem trabalhar aspectos estratégicos para que os membros alcancem um alto grau de comprometimento pela coesão do time. Assim sendo, é visto um agravante na análise da figura 10. Como já dito, é importante, sim, que haja uma comparação entre os níveis de motivações dos outros grupos para que possa haver a troca de experiência, visões estratégicas e maneiras 
de se fazerem acontecer as melhores práticas nas aulas. O docente como líder deve atentar-se a essa questão e semear um ambiente onde uma competição sadia ocorra, e a troca de saberes trabalhe em prol do processo ensino-aprendizagem. Sem a percepção de como sua equipe está se saindo em relação às outras, o líder do time pode se sentir inseguro e transmitir essa insegurança aos membros da equipe, pela ausência da percepção se o grupo está no caminho certo. $O$ docente, por meio de uma atuação individual e estimulo intelectual para com cada grupo, e um feedback proativo buscando o equilíbrio da qualidade entre os grupos, pode contribuir para a motivação de toda a sala de aula nos ambientes híbridos. Essas características de atuação são vislumbradas na Liderança Transformacional. Assim, é importante a cada equipe em particular atentar-se aos feedbacks do docente em relação a cada desafio, de cada grupo, para que dos mesmos possam tirar proveito para melhorarem suas estratégias de aprendizagem, mas se o docente permanecer muito distante dos grupos fica difícil o mesmo identificar essas nuances, e fornecer o feedback correto.

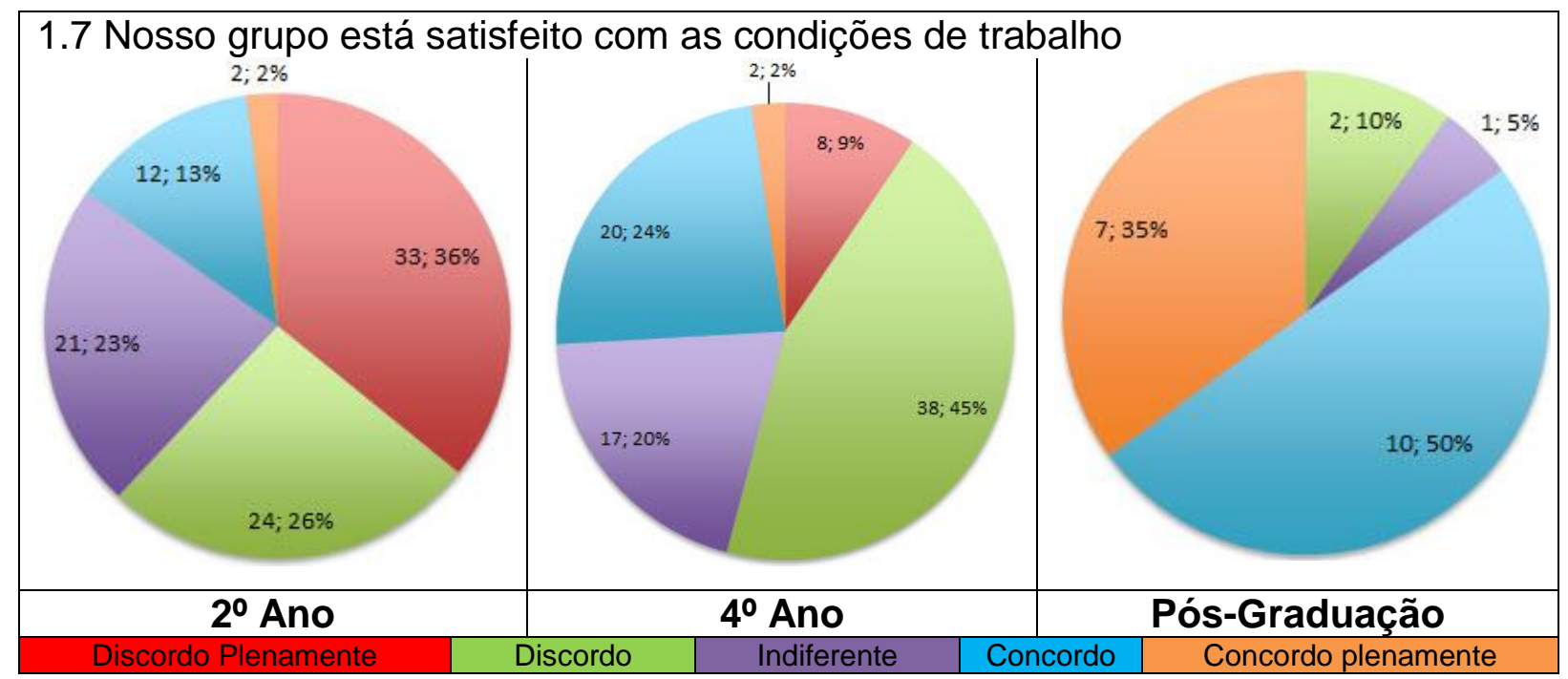

Figura 11 - Análise do índice de satisfação de grupo em relação às condições de trabalho 
A Figura 11 demonstra uma grande desmotivação dos estudantes da graduação em relação às condições de trabalho, com $62 \%$ dos estudantes do $2^{\circ}$ ano e $54 \%$ dos estudantes do $4^{\circ}$ ano desmotivados, contrastando novamente com a análise que os estudantes de pós-graduação teceram, gerando uma porcentagem de $85 \%$ de satisfação para com as condições de trabalho. A utilização do PBL para cada disciplina e uma mesma forma de emprega-lo, deixa visível a complexidade em sala de aula em ambientes híbridos quando comparamos estudantes de graduação e pós-graduação, e seus níveis de motivação. Talvez os processos utilizados pelo PBL também não tenham sido interpretados de uma forma proativa por parte dos estudantes de graduação devido à distância que ocorreu entre estes e o docente, 0 que repercutiu nas condições de trabalho na dificuldade da interpretação dos estudantes dos objetivos propostos pelo mesmo. Como o PBL desconstrói o modelo tradicional de ensino, voltado mais para aulas expositivas, faz com que, mesmo que de uma forma equivocada, os estudantes de graduação possam se sentir perdidos ao não perceberem que suas amarras foram soltas e agora eles podem se responsabilizar pelo seu próprio aprendizado, sem limitações. Acontece que os estudantes de graduação da engenharia aparentam, pelos discursos escritos analisados, não estarem preparados para darem esse salto sozinhos. É necessário a interferência do docente para guia-los constantemente, o que de certa forma contradiz o próprio $\mathrm{PBL}$, que sugere o estudante ser o responsável pelo próprio aprendizado. Essa lacuna pode ser preenchida pelo docente atuando com perfis de liderança que cubram as lacunas que o PBL pode deixar em um primeiro momento, interferindo inclusive nas condições de trabalho, aqui apontadas como frustrantes pelos estudantes de graduação. Um dos pontos a serem observados pelo docente é o número de estudantes presentes em cada disciplina. Liderar um grande número de 
pessoas demanda um maior nível de atenção e observação aos detalhes. Ao dividir os estudantes em equipes faz com que o controle dos processos de aula possam ser mais bem elaborados. É observado nos grupos da pós-graduação uma ampla aceitação das condições de trabalho, com $85 \%$ do fator positivo das variantes Concordo plenamente $(35 \%)$ e Concordo $(50 \%)$, sendo que uma maior maturidade do grupo e uma maior experiência prática na resolução de problemas foram notados nestes. Em relação ao item Indiferente marcado pelas turmas de graduação, foi observado na coleta dos dados que este item foi escolhido pelos grupos que alcançaram um menor índice nas avaliações finais feitas pelas notas atribuídas. A distribuição dos grupos deve ser feita cautelosamente conforme verificado após a observação de um fato preponderante: No dia em que se iniciaria a Taça Universitária de São Carlos - TUSCA, maior torneio universitário do Brasil, três equipes do $2^{\circ}$ ano de 2011 estiveram presentes em aula em sua totalidade. Ao analisar ao final do semestre o perfil dessas equipes, foi verificado que foram as 3 (três) equipes que melhor pontuaram nas avaliações finais. Essa questão gerou interesse do pesquisador, que entrevistou quatro elementos distintos dos grupos, entre eles os líderes dos mesmos. O que foi observado no discurso dos mesmos em relação à formação das equipes desde o primeiro dia de aula é que haviam estudantes nos grupos que não pertenciam às mesmas turmas que saiam frequentemente para festas e confraternizações. Eram elementos distintos, de turmas extraclasse diferentes. O nível de complexidade nesse fato foi em parte elucidado no discurso dos estudantes entrevistados.

A entrevista ocorreu com alunos do $2^{\circ}$ ano no $1^{\circ}$ dia da TUSCA, o maior torneio universitário no Brasil, momentos antes da saída do CORSO, um trio elétrico 
seguido por milhares de estudantes universitários, que festejam e comemoram o inicio dos eventos.

- Entrevistador (Marcos - Monitor/Pesquisador): Tem como você me ajudar e responder uma pergunta que ficou me intrigando hoje? Como foi feita a escolha de vocês irem na aula em um dia onde não prevíamos ninguém em sala? A decisão foi do grupo ou foi individual? Com base em que? Como você encara o fato de que as pessoas que estavam na aula eram todas pertencentes a grupos fechados que participaram ativamente de uma aula que vejo que foi muito produtiva? E o resto da turma?

Acredito que na Faculdade, começamos a formar grupos que se identificam pela postura de trabalho, sem considerar aspectos relacionados à amizade, talvez. E o melhor de tudo é que quando você encontra pessoas que possuem a mesma postura séria que você possui, laços de amizades podem ocorrer também, o que torna o ambiente prazeroso e ao mesmo tempo comprometido com os resultados... Abração pessoal $=\mathrm{D}$ (2011_SI_G03_Alun02).

Fala Marcos, não foi nada combinado, acho que isto aconteceu mais pelo fato de os grupos não terem sido formados de forma aleatória, desse jeito as pessoas que não são mais preocupadas com festas do que aula acabaram ficando no mesmo grupo (dos 5 que foram do meu grupo por exemplo, acho que 3 não foram no CORSO, por exemplo) (2011_SI_G02_Alun04).

$\mathrm{Na}$ verdade quem foi na aula são as pessoas que não faltam nas aulas mesmo, porque a TUSCA foi mais uma desculpa para faltar, e confesso que se a aula fosse a tarde somente quem não participa do CORSO iria na aula. E os grupos formados e que estavam presentes provam que são as pessoas que levam mais a sério 0 curso que sempre estão juntas (2011_SI_G01_Alun03). 
Então, acredito que a razão pela qual estivemos quase todos ontem foi pelo trabalho que já vínhamos desenvolvendo no decorrer dessas duas últimas semanas, inicialmente pelo gmail e depois pelo Google+, além disso, todos estiveram presentes na reunião em que montamos a primeira versão da apresentação sobre modelagem de empresas e havíamos combinado que todos leriam aquela bibliografia que você nos enviou do NUMA antes da reunião, eu agradeço a você pela bibliografia, pois foi de singular ajuda. $O$ único participante que faltou provavelmente não queria apresentar, mas não por mal, pois pelo contato que temos com ele, ele se mostra muito introvertido e resistente tanto para falar em público quanto ao se comunicar via redes sociais, mas é algo que está sendo melhorado, pois na última reunião online ele esteve presente (2011_SI_G03_Alun04).

Olha, Marcos, suas perguntas são difíceis de serem respondidas, por isso, vou começar falando no meu caso e depois tento extrapolar para os outros.

Como vc sabe, no dia anterior a aula era meu aniversário. Eu dormi cerca de duas horas antes de ir para a USP às 7:20. O que me levou a ir às aulas é que eu estou em São Carlos, antes de tudo, para estudar, e isso não pode ser esquecido em nenhum instante. Apesar de eu ter consciência que temos que aproveitar a vida acadêmica, vejo também que temos que nos preparar também para a vida profissional e não poderemos faltar de um dia de trabalho, porque decidimos ir a uma festa no dia anterior. Percebo que vc tem muita disposição em conferir à sala essa visão do mundo empresarial, então vc deve entender o meu ponto. Quanto ao meu grupo, estamos exatamente juntos por sermos amigos e compartilharmos essa ideia: que temos de participar das aulas. A nossa presença na aula é uma consequência deste fator. Acredito que a justificativa dos outros grupos estarem lá segue essa linha. Muito obrigado por ter me mandado essa mensagem, faz com que eu reforce meus ideais e vou passar essa excelente notícia ao grupo. Grande Abraço (2011_SI_G01_Alun02).

Por meio da análise do discurso desses estudantes pode-se entender que, se houvesse uma escolha aleatória por parte do docente dos membros dos grupos desde o início, o resultado final na avaliação dos grupos, advindo intrinsicamente dos fatores complexos dessas interações, não seriam os mesmos. Estudantes inicialmente comprometidos com os desafios fazendo parte de grupos de estudantes 
com um grau de comprometimento em menor escala reverteria em prejuízo ao estudante mais comprometido, e ao seu aprendizado. Por outro lado, a realidade das empresas nem sempre propicia a escolha das equipes que os futuros engenheiros irão integrar. A atuação do docente como líder transformacional identificaria essa situação e poderia fazer com que ele trabalhasse individualmente tais grupos e, até mesmo, individualmente alguns estudantes que estivessem fora do perfil da equipe, revertendo o que seria um aspecto negativo, em um processo de aprendizagem simulando um ambiente organizacional externo à classe. Desse modo, mesmo que um estudante comprometido estivesse em uma equipe não comprometida com seu grau de motivação, poderia se beneficiar de uma aprendizagem ainda mais enriquecedora, pois estaria sendo capacitado pelo docente a superar suas dificuldades na ausência de membros de seu grupo com o mesmo perfil, otimizando as condições de trabalho.

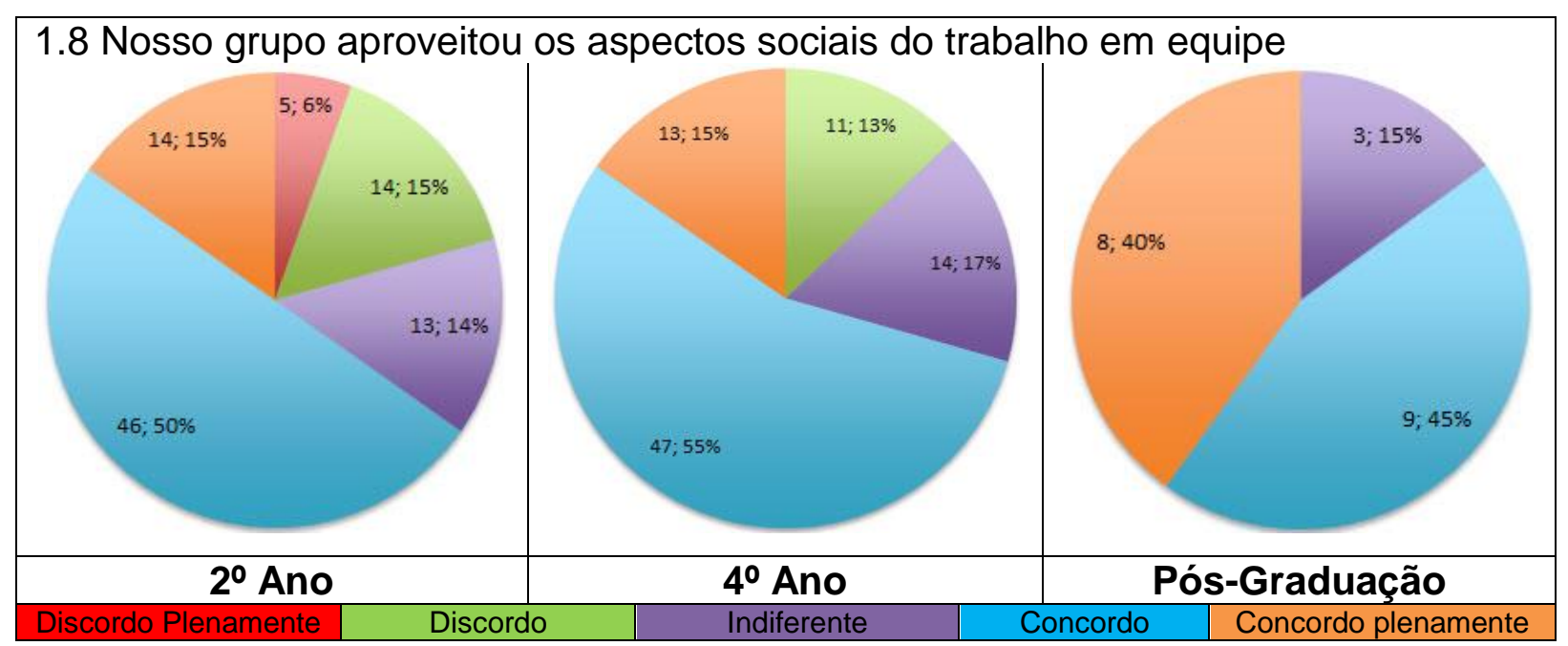

Figura 12 - Análise do índice de satisfação de grupo em relação aos aspectos sociais do trabalho em equipe

Aspectos sociais podem ser entendidos como uma possibilidade de, por meio da interação entre os membros dos grupos, novos conhecimentos emergirem por meio da criação, aquisição, transferência ou compartilhamento dos mesmos, muito 
disso pela análise de elementos que podem ser abordados de diferentes ângulos, sob diferentes direcionamentos, por meio de diferentes pensamentos reflexivos.

A Figura 12 aponta como realidade que estas interações ocorreram, que aspectos sociais foram aproveitados pelos grupos, com um grande índice de concordância em todas as disciplinas, mas parece que esse fato foi mais devido a uma cultura já presente nos mesmos do que por meio de estímulos externos, como o PBL. É muito importante o docente enquanto líder fomentar aspectos sociais nos alunos, inserindo-os em contextos que se assemelhem à realidade social que os mesmos vislumbrarão após concluírem seus estudos.

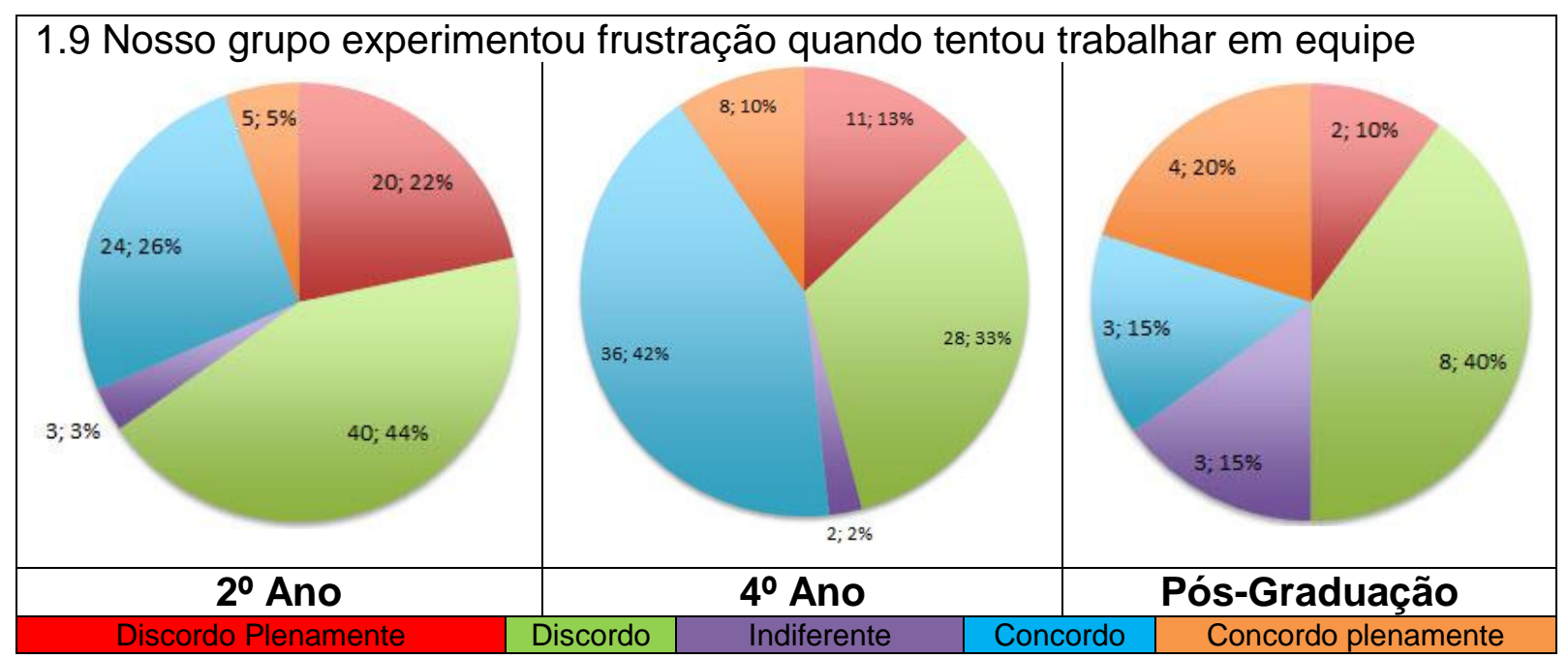

Figura 13 - Análise do índice de satisfação de grupo em relação à motivação em se trabalhar em equipe

Outro fator que identifica um alto grau de preparo, ou não, para se trabalhar em equipe nos desafios das disciplinas foi relacionado à frustração, que está diretamente atrelada ao nível de motivação. Pela Figura 13 observa-se a ampla complexidade vivenciada em sala de aula, inclusive pelos estudantes da pósgraduação, mais experientes. Frustraram-se em se trabalhar em equipe $31 \%$ dos estudantes do $2^{\circ}$ ano, $52 \%$ dos estudantes do $4^{\circ}$ ano e $35 \%$ dos estudantes da pósgraduação. Esse indicador pode demonstrar ausência de uma visão sistêmica por 
parte do docente ou dificuldade para se fazer valer o método PBL, uma vez que pela observância das teorias da liderança, com maior ênfase na Teoria da Liderança Transacional, fatores críticos de sucesso em sala de aula em ambientes híbridos podem ser identificados e combatidos a tempo e a atuação de um líder transformacional se evidencia em ambientes mais conturbados. Esse fato é importante de ser analisado e chega a ser, inclusive, necessário, pois a liderança pode nem sempre advir de uma concordância plena do grupo para com o docente, mesmo que o docente os dirija para melhores resultados, uma vez que existem fatores relacionados à empatia envolvidos, além da frustração poder ser advinda de fatores extrínsecos, como problemas de saúde, problemas familiares ou financeiros. Os líderes de cada grupo, ou os membros mais influentes, no momento que podem apresentar características diferentes, devem ser tratados diferentemente por parte do docente, uma vez que pela Teoria dos Sistemas Complexos, agindo proativamente nos elos mais influentes, a energia gerada repercute nos elos mais fracos, fortalecendo-os. De posse dessa afirmativa, é importante que o docente se atenha às características particulares de cada líder dos grupos e que entenda que da diversidade advém novas ideias e desafios, os quais posteriormente, com o sucesso de uma empreitada, pode reverter em know-how e experiência de vida ao grupo que enfrenta frustração. Há de se convir que a frustração muitas vezes pode ser necessária para que haja um crescimento quanto à inteligência emocional do indivíduo, item fundamental para se alcançar cargos gerenciais, conforme visto na teoria. 


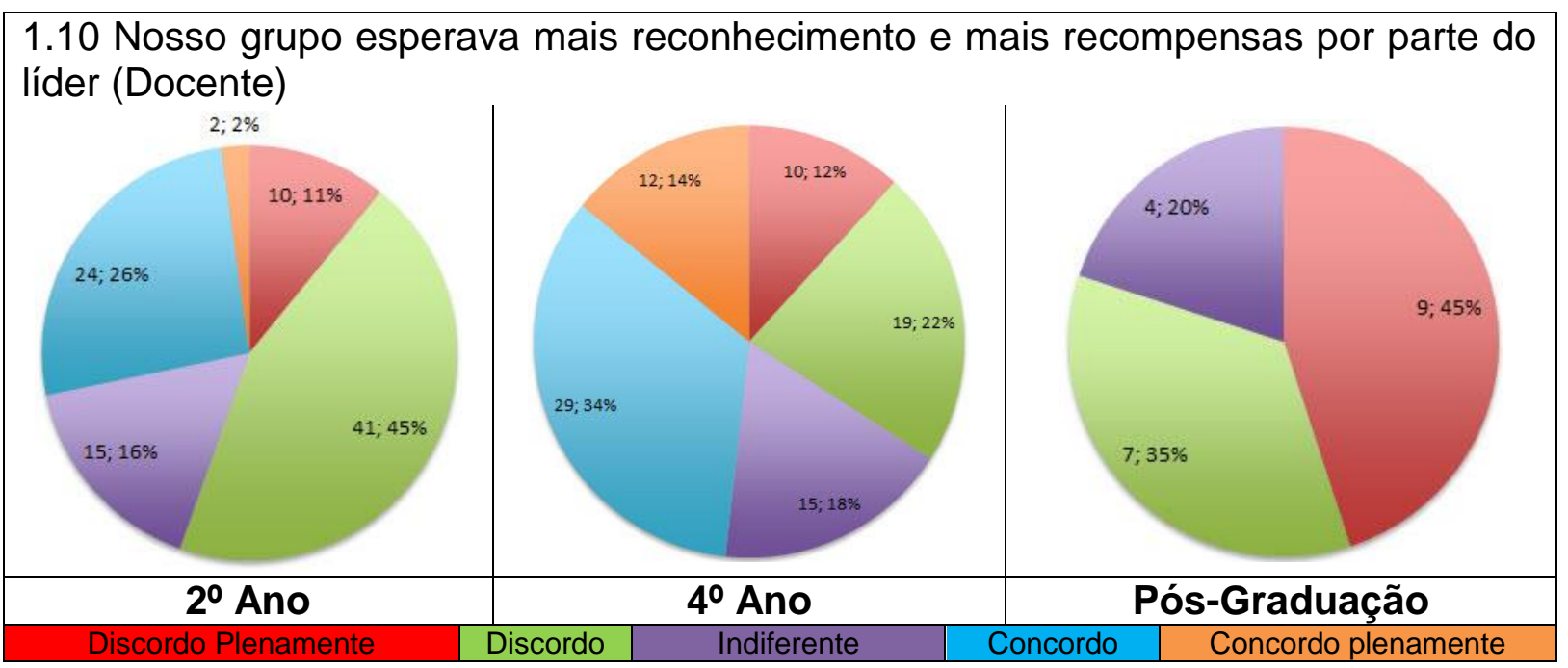

Figura 14 - Análise do índice de satisfação de grupo em relação ao nível de reconhecimento e recompensa por parte do docente

Como demonstrado na teoria (item 2.4.9), uma liderança por intermédio de recompensas por cada desafio cumprido é característica de uma liderança transacional, assim como punição quando não alcançadas as metas. A Figura 14 demonstra que os estudantes do $2^{\circ}$ ano da graduação e os estudantes da pósgraduação, com $56 \%$ e $80 \%$ respectivamente, não esperavam recompensas por parte do docente, enquanto $48 \%$ dos estudantes do $4^{\circ}$ ano esperavam. A variação em relação a este subitem demonstra que independente do grau de instrução dos estudantes, o docente pode se beneficiar atuando como líder motivacional na medida em que, pela teoria da liderança transformacional (item 2.4.10), essa atitude proativa do reconhecimento semeia a coesão de times no momento que pode quebrar barreiras que comprometam os desempenhos individuais e, consequentemente, do grupo. Não esperar reconhecimento e recompensa por parte do líder pode, também, significar por parte do grupo desinteresse para com um desafio, uma vez que de acordo com o visto na teoria, esses dois fatores motivacionais são essenciais no bom desempenho no cumprimento de objetivos. 


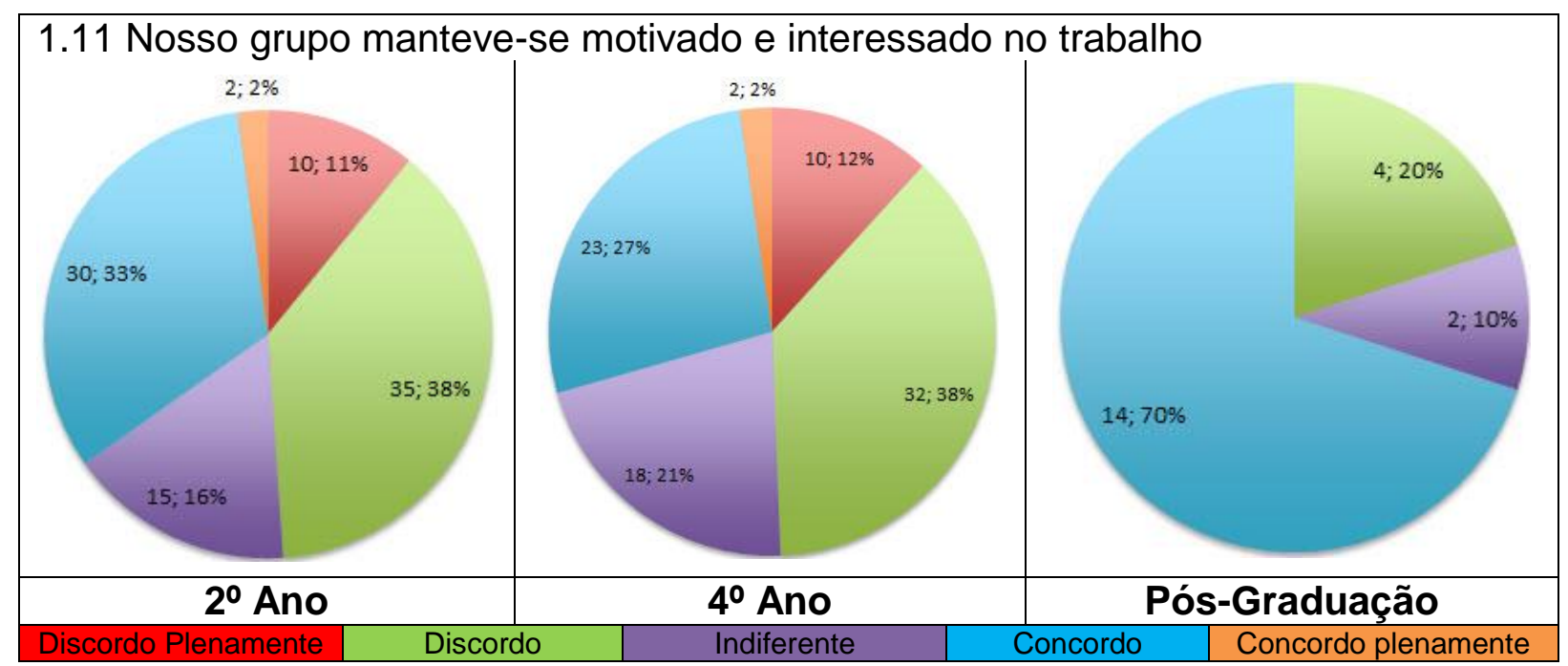

Figura 15 - Análise do índice de satisfação de grupo em relação à motivação para com os desafios apresentados pelo docente

A motivação é um dos ingredientes principais no fomento da adesão e coesão de pessoas para um fim, conforme demonstrado na teoria. Sem motivação não há a energia necessária para prover capacitações, pois pode haver, mesmo que imperceptivelmente, auto sabotagens internas que incapacite o aprendizado. Grande parte dos estudantes se mostraram desmotivados durante o decorrer dos desafios, inclusive $20 \%$ dos estudantes da pós-graduação, conforme demonstrado pela Figura 15. Trabalhando-se em meio à complexidade de uma sala de aula, e por intermédio da observação do pesquisador, notou-se que grande parte da desmotivação advinda dos membros dos grupos se deu pela incapacidade dos mesmos em lidarem com a mudança do paradigma do ensino tradicional proposto pelo método PBL. Enquanto alguns se mostravam interessados em determinados assuntos, outros membros da mesma equipe manifestavam-se alheios ao que se passava dentro da sala de aula, desenvolvendo atividades em sites de relacionamento, estudando matérias de outras disciplinas e saindo e entrando da sala de aula constantemente. A falta de compromisso de um membro da equipe pode comprometer a motivação de outro, pois a ação de um elemento reflete em outro positiva ou negativamente, conforme 
visto em sistemas complexos. É importante ao docente atentar-se a esse fato e agir de forma construtiva, realinhando os elementos que se apresentam distorcidos, seja interferindo em determinado processo de aprendizagem que esteja desconexo com determinado grupo, atuando individualmente nos porquês de determinados comportamentos do estudante, que o faz tomar determinadas atitudes. Atuando como líder, o docente se apossa de várias ferramentas educacionais que podem estar beneficiando esse processo de adaptação.

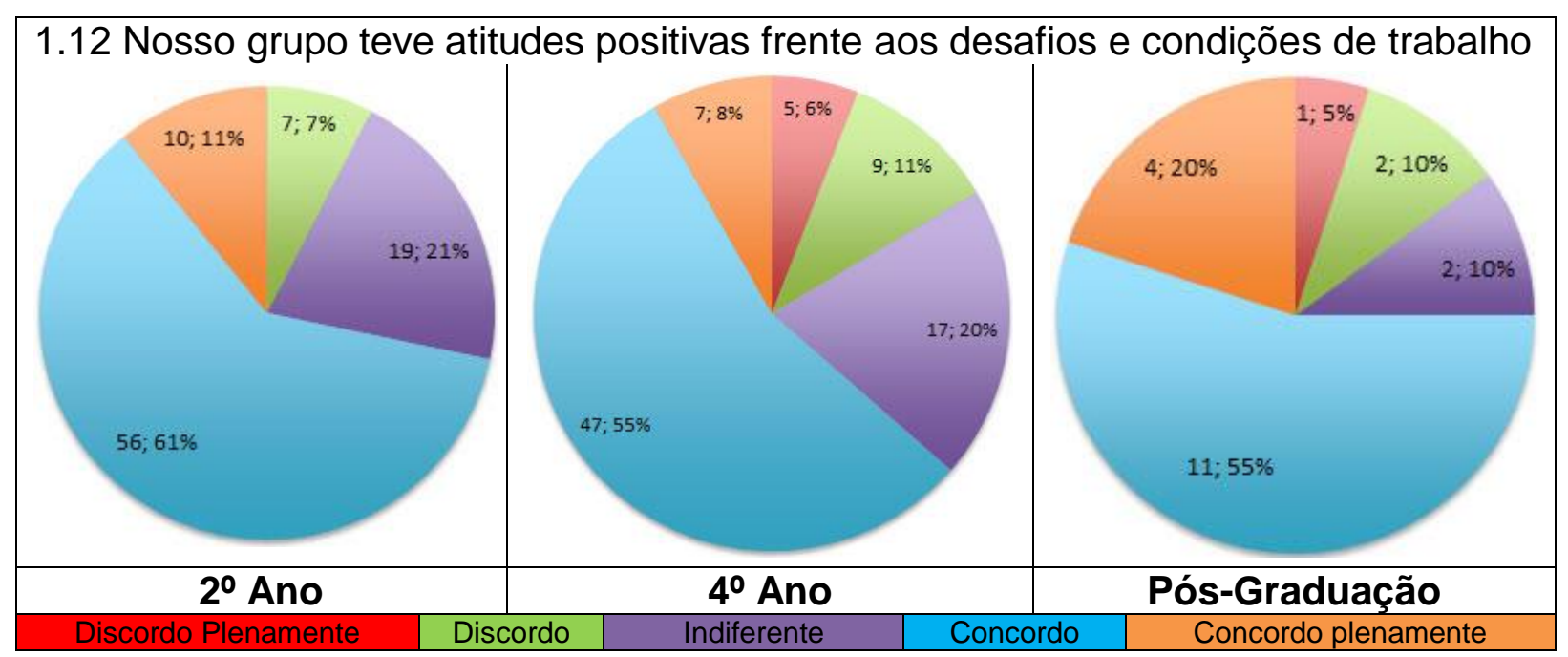

Figura 16 - Análise do índice de satisfação de grupo em relação aos fatores motivacionais intrínsecos ao grupo no percorrer dos desafios

A Figura 16 registra que todos os grupos, em uma visão geral, estavam de posse de uma atitude proativa em relação aos desafios e condições de trabalho, mesmo tendo estas condições de trabalho sido apontadas como insatisfatórias pela análise da figura 9 , o que demonstra que mesmo em meio a adversidade, o estudante procurou atuar de forma a combater os problemas, o que reverteu em frustração quando não obtiveram sucesso devido às falhas de comunicação para com o docente no decorrer das disciplinas, menos evidenciado na pós-graduação. $O$ 
índice de satisfação do grupo, como é de se esperar, pode não representar a satisfação individual.

\footnotetext{
...Quanto ao trabalho, fiquei descontente com o resultado. Acreditava, desde o início, que seria muito mais interessante se cada grupo fizesse o trabalho sobre um problema diferente. Após definir meu tema, acabei vendo que outro grupo tinha o mesmo. Descontente também, no fim da disciplina, achei que aprenderia várias ferramentas de apoio a decisão, mas não aprendi nenhuma, além de Brainstorm e OLAP, que nem praticamos... (2011_SAD_G06_Alun04).
}

O discurso do estudante 2011_SAD_G06_Alun04 demonstra bem essa realidade e a importância do docente atentar-se aos detalhes. A observação do comportamento dos estudantes por meio de suas expressões corporais, falas, atitudes e feedbacks são possíveis quando se atua por intermédio de perfis de liderança que incentivam essa abordagem, como a Liderança Transformacional e a Liderança Sábia, através da visão holística da sala de aula advinda da inteligência emocional.

\subsection{Identificação do estilo de liderança do docente.}

\subsubsection{Questão 2 do questionário (Apêndice 2) - "Minha percepção individual em relação ao docente da disciplina" e Sub-questões de 2.1 a 2.8.}

A análise dos resultados advindos das percepções individuais dos estudantes para com o docente visa identificar um elo de ligação para com os resultados da Questão 01 (índice de satisfação de grupo) nos ambientes híbridos. Para isso utilizou-se 3 (três) estilos de liderança na elaboração do questionário entregue aos 
estudantes: A Laissez-faire (questão 2.1), a Liderança Transformacional (Questões 2.2 a 2.5) e a Liderança Transacional (Questões 2.6 a 2.8). Por meio da análise dos gráficos e do discurso dos estudantes, fica possível gerar o entendimento dos resultados do Índice de Satisfação de Grupo e visualizar elementos que motivaram os resultados obtidos pelo mesmo, possibilitando também a correspondência com outros estilos de liderança estudados na teoria, os Sistemas Complexos e o PBL.

O primeiro item a ser analisado é a liderança Laissez-faire (Figura 17) por meio de uma questão referente ao grau de atuação do docente para com os alunos, ou seja, se ele coordenou as atividades de perto ou deixou por conta dos estudantes.

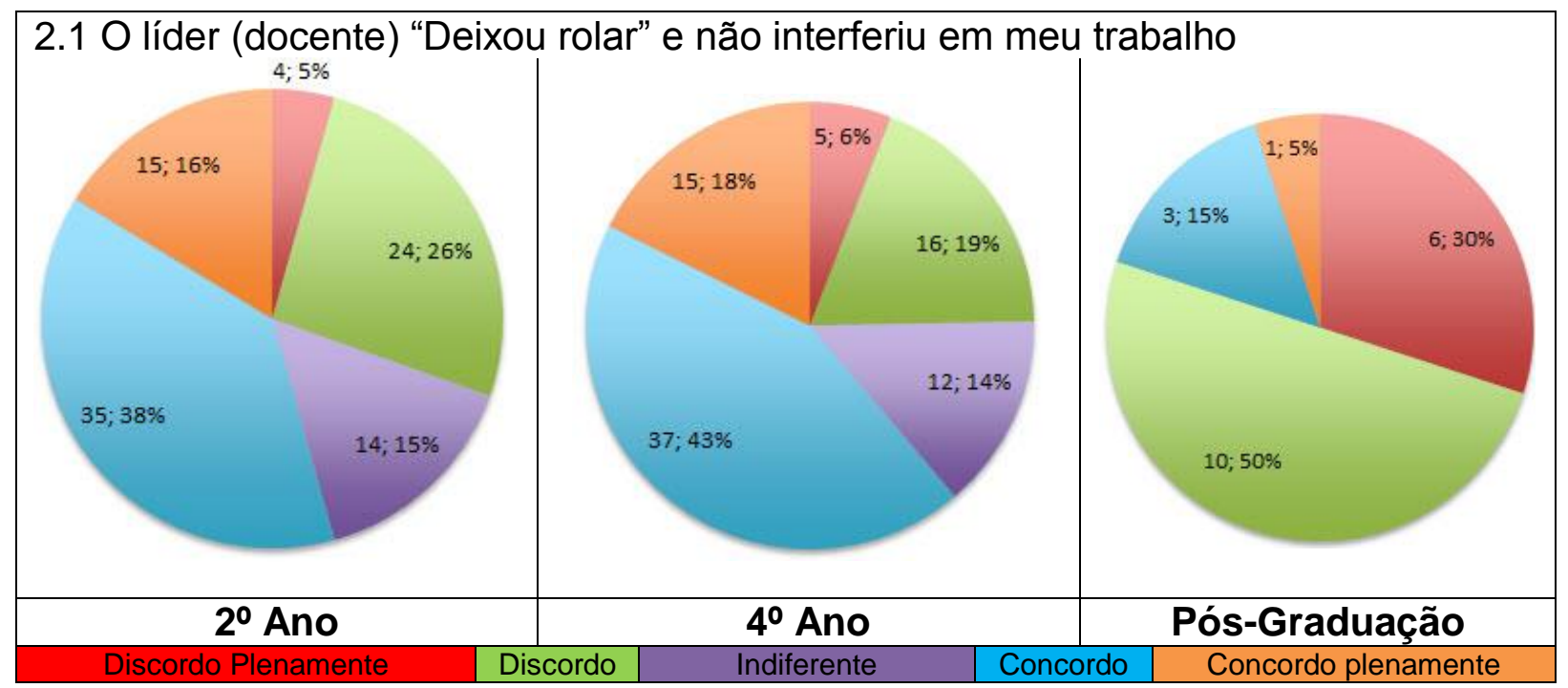

Figura 17 - Análise do perfil de liderança do docente relacionado ao estilo Laissez-faire

Analisando os gráficos presente na Figura 17, que referem-se ao de liderança Laissez-faire, $54 \%$ dos estudantes do $2^{\circ}$ ano, $61 \%$ dos estudantes do $4^{\circ}$ ano e $20 \%$ dos estudantes da pós-graduação apontaram que o docente da disciplina atuou com esse perfil comportamental ao optarem pelas alternativas Concordo plenamente e Concordo quando questionados se o docente não interferiu no trabalho. Essa 
questão remete aos Sistemas Complexos. Sistemas Complexos e a liderança estão intimamente interligados. Conforme identificado na revisão bibliográfica, a liderança nas organizações contemporâneas deve incluir a capacidade de antecipar, identificar e responder às ocasiões imprevisíveis (PORTER O'GRADY; MALLOCH, 2005). Rocha (1999) afirma que um sistema complexo é qualquer sistema com um grande número de componentes que interagem, cujas atividades agregadas são nãolineares e, normalmente, apresentam auto-organização sob pressões seletivas. A sala de aula é um grande exemplo de um sistema complexo e a liderança Laissezfaire, pelo seu atributo de não participação do líder, no caso o docente, senão quando questionado, e nenhuma tentativa de sua parte em interferir no curso dos acontecimentos, fornecendo ampla liberdade aos mesmos, resultou aos estudantes da graduação, menos experientes na resolução de problemas, uma dificuldade de adaptação ao ambiente no transcorrer da metodologia aplicada (PBL). Johnson (2007) ao afirmar que um sistema complexo adaptativo é altamente sensível às condições iniciais, que pode se adaptar de acordo com sua história ou feedback, que pode ser influenciado ou adaptar-se ao seu ambiente e que as relações entre o sistema e o seu ambiente não são triviais (ou não-lineares), fornece elementos para a análise do discurso de alguns dos estudantes das disciplinas de que este perfil de liderança atuou de forma determinante no índice de satisfação de grupo (Questão 1, Sub questões de 1.1 a 1.12). Essa afirmativa é corroborada pelo discurso escrito dos estudantes que se seguem.

A disciplina passou a sensação de ser muito jogada. Entendo a vontade do docente de fazer um processo de avaliação diferente, mas é algo muito novo para os estudantes, então todos ficaram muito perdidos por muito tempo no semestre. Portanto, o docente deveria ser o mais claro possível no início do semestre, talvez até pegar uma aula no meio para saber se restam dúvidas 
sobre o que deve ser feito. Uma breve introdução, com material didático introdutório, como uma apostila, já ajudaria bastante, além de escrever no quadro, procurando passar uma orientação toda semana, sobre o que deve ser feito, também ajudaria. No final do semestre aprendi o que é um SI, mas de forma alguma como gerar um, sabendo exatamente o que deve conter (2012_SI_G08_Alun04).

Tirar um pouco a importância da participação no Facebook e priorizar a participação em sala de aula e a elaboração do projeto, pois, no Facebook acabam postando reportagens que não contribuem significativamente no aprendizado, só para obterem nota de participação (2012_SI_G04_Alun05).

A importância dada ao Facebook é excessiva, irreal. O que foi feito por meio deste meio foi, na maioria das vezes, totalmente fora do contexto e do conteúdo do curso, visto que a maioria dos posts não tinham relação com a matéria. Sugiro que os métodos de avaliação sejam definidos previamente, e não sejam alterados com o decorrer do tempo (como foi feito). Os trabalhos também devem ser melhor definidos, para que os estudantes possam compreende-los e realiza-los sem hesitação (2012_SI_G04_Alun06).

Acredito que durante $o$ andamento da disciplina faltou uma melhor explicação de como seriam realizados os trabalhos e a utilização das mídias sociais. Além disso, a disciplina exigiu um tempo de trabalho fora de aula que considero excessivo, considerando que estamos no fim do curso e estamos procurando estágio e fazendo processos seletivos (2012_SAD_G04_Alun04).

Creio que o Facebook não pode ser utilizado como ferramenta de ensino. Acho também que os estudantes da USP não estão preparados para esse método de ensino, que seria muito melhor se fosse substituído por aulas práticas (cases) e mais trabalhos. Achei a disciplina entediante e cansativa. Os métodos de avaliação de equipe não são válidos e o fato de postar no Facebook por obrigação é um absurdo. Um bom curso de Excel seria muito mais útil para a minha formação (2012_SAD_G06_Alun02).

Disponibilizar bibliografia; Incluir prática (aula); Disponibilizar "cases" (2012_SAD_Pós_G01_Alun03). 
Utilizar mais o Moodle para troca de materiais; divulgação de "tarefas" para a aula seguinte; fóruns para discussão sobre trabalhos em equipe (2012_SAD_Pós_G02_Alun03).

Explicações mais claras do docente sobre o que precisamos fazer. A sala, como um todo, sentiu-se perdida na disciplina (2011_SI_G01_Alun01).

Maior retorno com relação ao que está sendo pedido na disciplina para um melhor entendimento da mesma por parte dos estudantes (2011_SI_G03_Alun01).

Acho que poderia haver mais intervenções do docente no andamento dos trabalhos, na forma que ele falasse mais claramente os objetivos que cada apresentação deveria atingir. Poderia também haver mais explicações teóricas por parte do docente sobre os assuntos abordados na aula para que assim a pesquisa dos estudantes fosse mais direcionada para onde se deseja (2011_SI_G02_Alun03).

Em minha opinião a disciplina foi mal encaminhada sendo o aprendizado dentro de sala quase nulo... Um melhor direcionamento e maior intervenção do docente seria bem vinda para melhor aprendizagem do estudante e do grupo. Como não havia cobrança por parte do docente, os grupos deixaram de se preparar para as aulas, restando apenas dois grupos "interessados " no andamento da disciplina. Sobre isso falta uma melhor observação do docente. Avaliado o outro grupo ficou clara a discrepância entre os grupos no desenvolvimento do modelo EKD (2011_SI_G03_Alun03).

O método de aplicação dos conteúdos estudados na prática é muito bom, porém falta um pouco mais de direcionamento e explicações do docente. Se houvesse esse direcionamento, os estudantes se dedicariam mais e a matéria seria interiorizada por eles (2011_SI_G03_Alun07).

De modo geral passou longe de atingir as minhas expectativas. Faltou muito contato estudante-docente. Ficávamos sempre perdidos com o que era para ser feito. Não tínhamos retorno do que tínhamos feito. Muito do que fizemos foi em vão, faltou direcionamento para aonde procurar o que. O nível de aprendizado foi muito baixo. Sistemas de informação deve ser muito abrangente e uma vez estudado durante 1 semestre deveríamos ser capazes 
de usá-lo na vida real. No entanto, isso não ocorreu devido à falta de apoio e ensino (2011_SI_G04_Alun02).

Repassar aos estudantes como estão sendo os seus desempenhos (2011_SI_G03_Alun05).

A turma se mostrou insatisfeita com 0 modo em que o docente estava aplicando a metodologia da aula e ele se mostrou inflexível. Sugiro que, primeiramente, os ministrantes da aula ouçam a opinião da turma e façam um plano de ação para tal. Não adianta só ouvir. Passamos a maior parte do tempo na "introdução" da matéria. O docente poderia melhorar sua didática tanto em oratória, como no conteúdo, poderia trazer casos reais relacionados a matéria. A aula também precisa ser mais dinâmica, o docente passa muito tempo falando a mesma coisa. Todos os ministrantes precisam se organizar e planejar melhor, entrando em um consenso (2011_SI_G05_Alun02).

Eu "sugestiono" ao docente passar em nota como foi o desempenho do trabalho para dessa forma termos base para melhorar (2011_SI_G07_Alun02).

O docente deveria dar maior retorno aos estudantes com relação ao desempenho dos mesmos (2011_SI_G07_Alun03).

$\mathrm{Na}$ minha opinião, a falta de comunicação estudantes-monitores-docente prejudicou bastante andamento da disciplina (2011_SI_G07_Alun04).

Maior objetividade na avaliação das equipes (2011_SI_G06_Alun03).

Não ficou claro o que tinha de ser estudado e/ou pesquisado; Não teve exemplos práticos feitos pelo docente. Quando o docente explicava algo, ficava em um tom monótono, que dificultou o interesse ao aprendizado (2011_SI_G06_Alun05).

O docente poderia ter sido mais claro na hora de enviar os trabalhos e falar 0 que ele queria claramente (2011_SI_G07_Alun01).

A disciplina fez valer a pena o crédito do trabalho existente, pois a organização, a busca de informações, o entendimento dos assuntos e a 
preparação das apresentações consumiu o equivalente em tempo como se fossem 2 créditos. No entanto, toda essa preparação gerou resultados positivos quanto ao entendimento dos assuntos abordados, pois impulsionava a pesquisa e leitura crítica constante dos dados que eram pesquisados (2011_SI_G03_Alun06).

Apresentar a nota de acordo com a apresentação, para que os estudantes saibam como foram e se precisam melhorar (2011_SI_G07_Alun06).

Deixar mais claro o que se espera dos estudantes e como eles serão avaliados (2011_SAD_G03_Alun01).

Acredito que a disciplina deveria ter um cronograma mais bem estruturado visto que muitas vezes o grupo não sabia o que fazer e entregar (2011_SAD_G02_Alun01).

Talvez o melhor direcionamento e planejamento da disciplina, muitas vezes chegava na véspera da aula e o grupo não sabia o que deveria entregar na aula. A liberdade no desenvolvimento do projeto é muito bom, porém, acaba deixando meio vago 0 que se espera por parte do docente (2011_SAD_G03_Alun03).

O conteúdo que estava na ementa quase não foi abordado. Não se teve um direcionamento correto. Todos pareciam estar um pouco perdidos sobre o que fazer. Não houve motivação por parte dos estudantes. Talvez pudesse haver uma integração maior entre o proposto pela ementa e o trabalho, com o escopo definido (2011_SAD_G06_Alun03).

O docente deveria estabelecer melhor as expectativas do trabalho no início da disciplina e dar mais direcionamento ao grupo. Em vários momentos o grupo estava "perdido" sobre o trabalho (2011_SAD_G07_Alun03).

Acredito que o formato de trabalho em grupo - foco em PBL - é bastante interessante. Sendo assim, um maior foco nas equipes e no desenvolvimento dos trabalhos e propostas de forma ainda mais próximas podem gerar mais conhecimento e discussões durante as aulas. Ótima disciplina! (2011_SAD_PósG03_Alun02). 
...Desde o início não ficou muito claro qual era o problema que deveria ser analisado ao longo da disciplina. O docente sugeria coisas novas que nos faziam mudar o foco do trabalho... (2011_SAD_G01_Alun05).

...A não definição com antecedência de entregas ou como seria a avaliação, e quando seria realizada, dificultou o trabalho, pois os membros do grupo não conseguiam analisar a urgência das tarefas ou mesmo o que deveria ser feito. Assim, era impossível levar a disciplina paralelamente ao resto da graduação sem quebras de ritmos e surpresas desagradáveis semana após semana... (2011_SAD_G07_Alun02).

Pelo discurso escrito dos estudantes, e a análise da figura 17, evidencia-se a liderança do docente como sendo predominantemente Laissez-faire, muito disso, nas observações do pesquisador, pela crença que o método PBL deva ser implantado desde um primeiro momento apostando na capacidade de o estudante externalizar o pensamento crítico, indo em busca do fomento do próprio conhecimento sem uma preparação prévia, o que gerou muita confusão entre os estudantes da graduação.

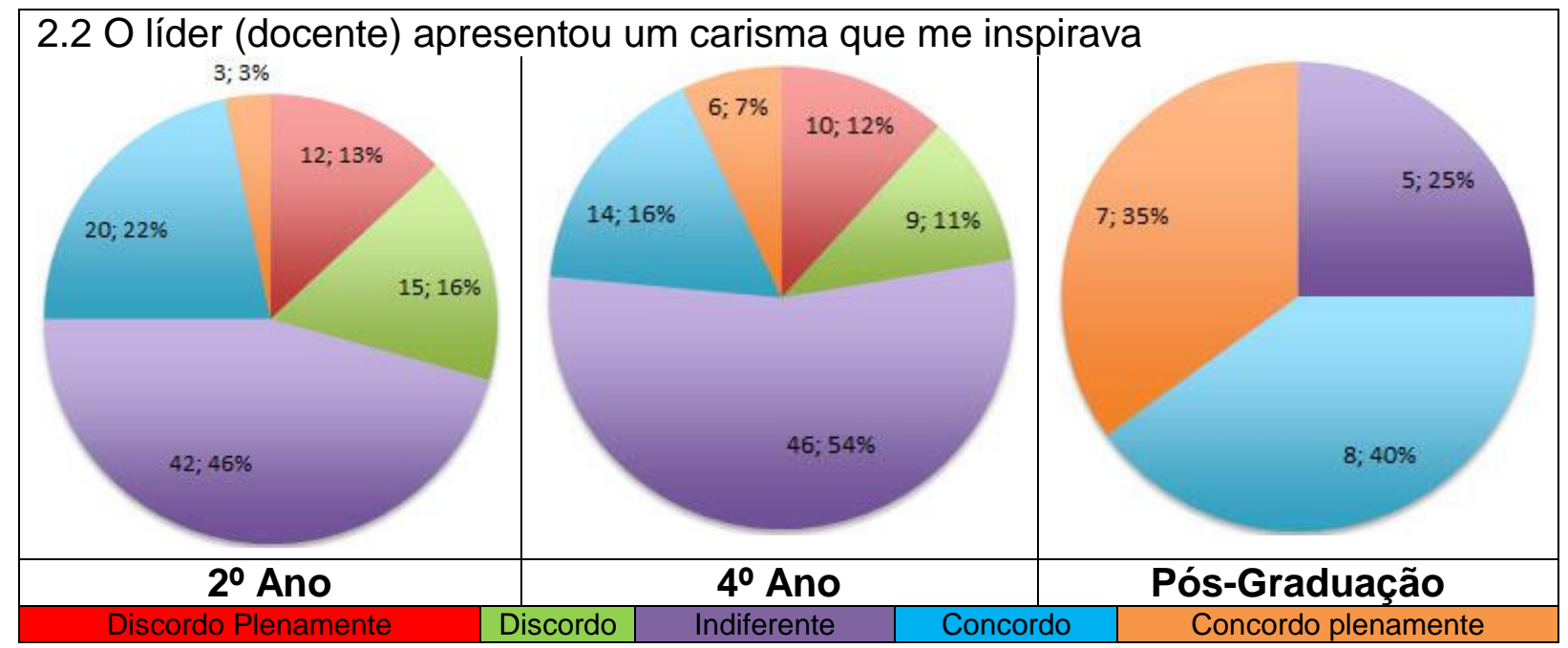

Figura 18 - Análise do perfil de liderança do docente relacionado ao estilo Transformacional pertinente à dimensão do carisma 
O carisma, dimensão de uma liderança transformacional, pode ser apontado como um diferencial quando bem direcionado. Existem controvérsias em relação se um líder carismático agrega na maior parte das vezes um valor positivo a uma equipe por meio de suas inferências. $O$ ambiente vivenciado em sala de aula nos contextos estudados foi identificado pelos estudantes pelo Índice de Satisfação do Grupo, Questão 1, como propício quando o fator estudado foi a interação entre eles e seus grupos, ao mesmo tempo em que o estilo de liderança Laissez-faire do docente interferiu negativamente para que esse índice de satisfação de grupo revertesse em resultados positivos para a maioria dos estudantes em termos de notas. Isso foi evidenciado no discurso dos estudantes na sub-questão 2.1. O carisma parece não ser fator impactante no resultado final de um desafio, o que fica evidenciado pelos gráficos presentes na Figura 18. Na complexidade vivenciada em sala de aula durante os semestres estudados, mais demonstrados nas turmas de graduação, o estudante mais bem avaliado, líder da equipe com melhor índice de desempenho entre todas as disciplinas, não apresentou traços de uma liderança carismática, tornando-se precipitado afirmar que o carisma do docente possa influenciar negativamente os estudantes nas disciplinas ministradas, mesmo porque seu estilo Laissez-faire impediu que outros traços de sua personalidade no contexto estudado aflorassem entre as equipes da graduação, com exceção a $25 \%$ das turmas do $2^{\circ}$ ano e $23 \%$ das turmas do $4^{\circ}$ ano, que apontaram traços de carisma e inspiração no docente (figura 18). Considerando que $75 \%$ dos estudantes da pósgraduação apontaram na questão o docente como um líder carismático, uma vez mais fica evidente a necessidade de o docente adaptar-se a determinados contextos, uma vez que estudantes da graduação tiveram uma percepção diferente sobre carisma e inspiração do que os de pós-graduação. Vale frisar também que, 
como visto na literatura em relação à liderança carismática, os seguidores não seguem o líder carismático pelo medo ou recompensa, mas por amor, veemente devoção e entusiasmo. Seguidores de líderes carismáticos não estão atuando em um papel onde há a preocupação com a carreira, promoção, salário ou benefícios (TUCKER, 1968), e no contexto das IES, em busca de notas. Nessa conjuntura, a inteligência emocional de um indivíduo, identificando de forma sistêmica características do ambiente no qual está inserido, deve ser vista como um dos elementos integradores entre o carisma, a liderança e os resultados. Um líder pode ser extremamente carismático, mas ser desprovido de uma integridade pessoal que remeta sua equipe a atingir o melhor não apenas a ela, mas à organização como um todo. Indo além, Purvanova e Bono (2009); Hesburgh (1988); Kouzes e Posner (1995); Moxley (2000) entendem que integridade pessoal, com firmeza de propósito, persistência e constância de caráter, com alto grau de manutenção e disseminação da esperança entre as pessoas e suas metas, adaptando-se a situações problema e atuando como exemplo de dedicação a um fim, são frutos de uma inteligência emocional atrelada ao altruísmo e podem motivar por meio do carisma um individuo ou uma equipe a obterem melhores desempenhos. Fica assim evidente que a inteligência emocional e sua característica holística e integradora deve ser utilizada na condução de disciplinas na engenharia por parte do docente, que de posse da mesma, pode atuar por meio de diferentes perfis de liderança, com determinados ingredientes que fomentem a criação ou aquisição do conhecimento sem estarem ausentes dos processos mais cognitivos. O carisma do docente em si não é fator crítico de sucesso em uma disciplina, mas pode contribuir se o líder carismático agir com ética perante sua facilidade de fomentar seguidores. 


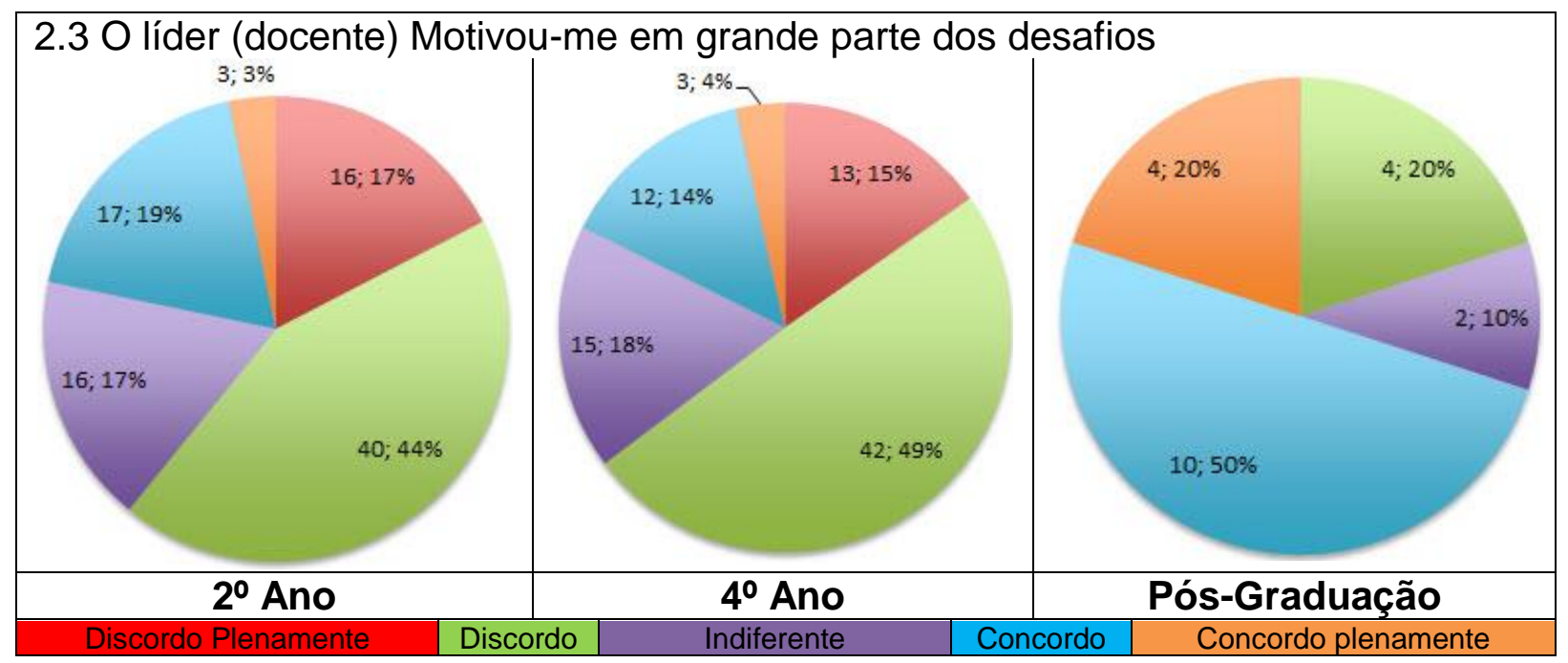

Figura 19 - Análise do perfil de liderança do docente relacionado ao estilo Transformacional pertinente à dimensão da motivação

Kolstoe (1975, p. 61, tradução livre) afirma que "ninguém pode ensinar nada a ninguém" se não houver motivação. Conforme verificado nos gráficos da Figura 19, $61 \%$ dos estudantes do $2^{\circ}$ ano da graduação discordam, ou discordam plenamente, que houve motivação por parte do docente em sala de aula no decorrer da disciplina, ao mesmo tempo que $22 \%$ concordam ou concordam plenamente que sim, houve motivação por parte do líder da disciplina. Bass e Avolio (1994) apontam a motivação inspiradora é uma das dimensões da liderança transformacional. Até esse momento da análise do estilo de liderança do docente nas disciplinas, o mesmo é apontado por estudantes da graduação como uma liderança Laissez-faire. No manual WHAT Works (1986), como visto no item 2.6, é dito que alguns estudantes encontram muita competição nas aulas de engenharia e sentem que eles nunca são recompensados por seus esforços. Migrando essa realidade para 0 contexto estudado na engenharia de produção da EESC-USP, o discurso de alguns estudantes do $2^{\circ}$ e $4^{\circ}$ anos podem identificar mais claramente como foi enxergado por eles o estilo de liderança do docente, validando ou não o que encontramos na figura 19 e os fatores que geraram desmotivação. 
O Moodle é muito bagunçado com relação as atividades: os prazos não são padronizados; os títulos com datas todas erradas, gerando uma grande confusão e estresse. O Facebook foi uma ferramenta desmotivadora e desviou-se do foco da disciplina (ninguém achou o trabalho lá satisfatório ou interessante). Os monitores e o docente não davam ouvidos às sugestões de mudança de metodologia, desmotivando 0 interesse na disciplina (2012_SI_G05_Alun05).

Acho que deveria ser dada de outra maneira, deixando os objetivos mais claros e assim motivando os estudantes a participarem mais ativamente da disciplina (2012_SI_G08_Alun02).

Utilização de Sistemas da própria universidade para que os estudantes possam interagir com a disciplina e não mídias sociais quaisquer. Explicações muito mais precisas dos trabalhos a serem realizados. Maior exploração do conteúdo da disciplina para que os estudantes possam ter uma base teórica para o desenvolvimento de suas tarefas. Priorizar atividades e participação em sala de aula e não no Facebook, destacando a qualidade e não a quantidade! (2012_SI_G04_Alun03).

A inexistência de critérios de avaliação prejudica muito o acompanhamento do desenvolvimento da disciplina. As questões levantadas pelo docente em sala de aula não são pertinentes ao aprendizado esperado, apresentando inclusive muita inconsistência conceitual. O Moodle não é um ambiente que favorece os trabalhos da disciplina. A impressão que fica é que os estudantes ficaram desmotivados durante toda a disciplina (2012_SAD_G01_Alun06).

Melhor organização dos acontecimentos realizados em sala de aula (2012_SI_G07_Alun03).

Organização e aviso prévio dos acontecimentos do Moodle (2012_SI_G07_Alun04).

Apenas ao final da disciplina foi percebido, por uma parte dos estudantes 0 quão importante e interessante era a disciplina. Uma pena, pois poderíamos ter aproveitado muito mais esse período. Sugiro que nas próximas turmas a equipe desenvolva uma metodologia mais eficiente para: Expressar o que 
queiram dos estudantes; avaliação precisa; motivar os estudantes; tornar a aula menos monótona; organizar o Moodle por datas das aulas e tarefas para cada data (2011_SI_G01_Alun02).

No entender do membro 2011_SI_G01_Alun02 visto anteriormente é enunciado que somente ao final da disciplina foi percebido pelos estudantes a importância e o quanto interessante era a disciplina, sugerindo maior eficiência quanto ao método, maior motivação e comunicação mais assertiva. Fica evidenciado que somando-se a esses aspectos, a falta de reconhecimento, fator desmotivador, contribuiu para a disciplina não ser relevante em aspectos motivacionais desde o começo. A falta de alinhamento da metodologia entre o docente e estudantes, visto como confusa, foi fonte de desmotivação,

Muitas vezes houve confusão sobre o que deveria ser apresentado na aula seguinte (2011_SAD_G01_Alun04).

o que remete novamente a uma análise do motivo da maioria dos estudantes do $2^{\circ}$ ano terem apontado o docente como não motivador, explicitamente descrita pelo membro 2011_SI_G03_Alun04 em sua análise da disciplina no final do semestre,

Acredito que o principal motivo dos problemas enfrentados foi a falta de motivação. Não tínhamos nenhuma expectativa em relação à disciplina. Nosso grupo foi o mais engajado entre os da classe, mas não me desenvolvi na disciplina. Essa motivação inclui tanto o lado ruim de forçar o estudante por notas quanto estimulá-lo a ter interesse em ser aprofundar na matéria. A falta de rigidez na disciplina é muito desestimuladora. Aconteceu uma espécie de reação em cadeia nesse sentido. Houve a perda da credibilidade da matéria (2011_SI_G03_Alun04).

validando o descrito pelos membros de diferentes grupos 2011_SI_G04_alun03, 2011_SI_G05_Alun01 e 2011_SI_G05_Alun01, 
A disciplina foi mal ministrada. Havia conflito das informações passadas pelo docente e pelos monitores. Além disso, nunca ficava claro o que tínhamos de fazer e quais eram os objetivos dos trabalhos. $O$ docente não motivou nem estimulou os estudantes a se interessarem pelo tema (2011_SI_G04_Alun03).

Faltou organização e comunicação entre docente, monitores e estudantes.. As aulas não era estimulantes, e o trabalho feito, poucas vezes foi reconhecido (2011_SI_G05_Alun01).

que são apoiados mesmo por estudantes que compreenderam o método e observaram aspectos positivos nas críticas construtivas do docente para um melhor aprendizado, como os membros 2011_SI_G05_Alun04 e 2011_SI_G07_Alun05

Apesar de compreender a ideia da metodologia, acho que falta motivação aos estudantes para se adequar a ela. Mas, uma vez que no início do semestre os estudantes sejam motivados, e se habituem a realizar trabalhos dentro do padrão exigido pelo método, o resto do semestre teria uma melhor fluência (2011_SI_G05_Alun04).

O docente em algumas aulas abordou o mesmo assunto, retardando a programação de aulas; no entanto, regularmente fazia críticas construtivas para um melhor aprendizado (2011_SI_G07_Alun05).

Importante frisar que $22 \%$ dos estudantes da disciplina do $2^{\circ}$ ano apontaram 0 docente como líder motivador, o que remete novamente à complexidade em sala de aula, uma vez que desses $22 \%, 10 \%$ eram membros de grupos com avaliações medianas, e não foram contaminados pelo efeito cascata apontado pelo elemento 2011_SI_G03_Alun04 ao ter discursado:

Acredito que o principal motivo dos problemas enfrentados foi a falta de motivação... Não tínhamos nenhuma expectativa em relação à disciplina... Nosso grupo foi o mais engajado entre os da classe, mas não me desenvolvi 
na disciplina... Essa motivação inclui tanto o lado ruim de forçar o estudante por notas quanto estimulá-lo a ter interesse em ser aprofundar na matéria... A falta de rigidez na disciplina é muito desestimuladora... Aconteceu uma espécie de reação em cadeia nesse sentido. Houve a perda da credibilidade da matéria

Essa reação em cadeia gerada pela desmotivação em sala de aula apontada pelo estudante 2011_SI_G03_Alun04 aparenta estar relacionada à teoria da complexidade (WEAVER, 1948), mais precisamente aos Sistemas Complexos Adaptativos (HOLLAND, 2006). Mais complexo torna-se a análise desse discurso quando é verificado que o estudante que o elaborou foi o estudante melhor avaliado e líder do melhor grupo entre todas as disciplinas. As observações desse estudante 2011_SI_G03_Alun04 e a avaliação que ele obteve dos membros do próprio grupo, que o apontaram como autoritário e transacional, induz a afirmação que o fato de não ter sido motivado repercutiu em sua forma de liderança, tendo de agir impondo pressão na equipe, o que obteve resultado pelo fato de sua equipe ter sido a que obteve melhor média de notas. O docente, ao não motivar o líder do melhor grupo individualmente, fez com que o grupo se adaptasse à liderança apenas do aluno mais influente, com perfil autoritário, remetendo-nos novamente à teoria, que nos fornece elementos para descrever como a liderança transcende o individuo e é um fenômeno do sistema, que pode se adaptar em situações adversas em ambientes complexos. Neste caso em específico, a liderança autoritária do aluno remete à teoria da liderança complexa (MARION; UHL-BIEN, 2001), que repercutiu em ótimos resultados por parte de sua equipe, que poderiam ter sido ainda mais positivos se 0 aluno tivesse atuado com uma liderança transformacional, conforme nos demonstra os resultados de estudos sobre como este estilo de liderança supera outros em termos de produtividade. 
Embora a teoria da liderança complexa seja uma abordagem cujo a ênfase em muitos momentos afasta o indivíduo como líder, de forma alguma diminui a importância da liderança como um fenômeno organizacional, mas sim, reconhece que a liderança transcende o indivíduo, sendo fundamentalmente um fenômeno do sistema, que é um conjunto de elementos interconectados, de modo a formar um todo organizado (HAZY, 2006; MARION; UHL-BIEN, 2001, 2003; UHL-BIEN et al., 2004).

A teoria da liderança complexa, como visto anteriormente, direciona 0 pesquisador a entender o fenômeno no qual uma equipe não motivada pelo perfil Laissez-faire do docente, e pressionada pelo autoritarismo de seu próprio líder, tenha alcançado seu resultado: por meio de um Sistema Complexo Adaptativo onde a qualidade individual gerou uma automotivação de membros da equipe que superou até mesmo conflitos internos observados na análise da avaliação do melhor líder como autoritário e não carismático.

Em relação aos estudantes do $4^{\circ}$ ano, apenas $18 \%$ apontaram o docente como motivador, contrastando com os $70 \%$ de aprovação ao docente como líder motivacional pelos estudantes da pós-graduação. A percepção de uma liderança Laissez-faire entre estudantes da graduação e pós-graduação novamente é discordante. O grau de maturidade dos estudantes, a quantidade de aulas (2 aulas/semana na graduação e 4 aula/semana na pós-graduação) e o número de estudantes em sala aparentam ter influenciado o desempenho do docente, uma vez que na pós-graduação o docente conseguiu atuar de uma forma mais individualizada e estimuladora nos grupos, traço de uma liderança transformacional. 


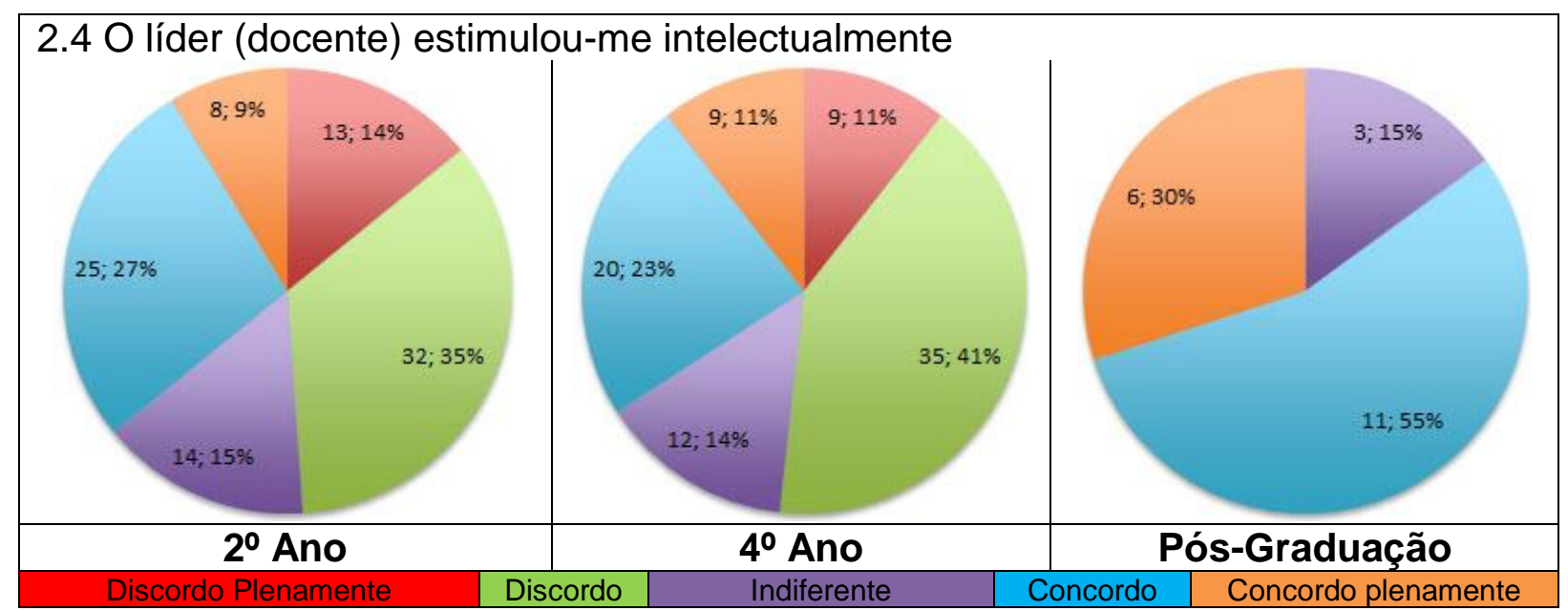

Figura 20 - Análise do perfil de liderança do docente relacionado ao estilo Transformacional pertinente à dimensão do estímulo intelectual

O estímulo intelectual, uma outra dimensão de uma liderança transformacional, surge como um fator crítico de sucesso nas turmas de graduação da engenharia, uma vez que pelo discurso da maioria dos estudantes analisados até o momento, um perfil Laissez-faire de liderança por parte do docente fez com os grupos se sentissem confusos e sem orientação, tanto no ambiente físico da sala de aula como nos ambientes virtuais utilizados (Moodle, Google+e Facebook). Nonaka (1991) afirma que as pessoas não recebem um novo conhecimento de forma passiva; elas o interpretam ativamente, adaptando-o às suas próprias situações e perspectivas. Assim, o que faz sentido em um determinado contexto pode mudar ou até mesmo perder o sentido quando comunicado a pessoas de contextos diferentes. Resultado é que houve confusão contínua quando um novo conhecimento é difundido em uma organização, cabendo ao líder direcionar essa confusão para a criação do conhecimento, direcionando os tomadores de decisão a uma atitude proativa se o objetivo for a criação ou aquisição de conhecimento. No contexto de uma grande instituição de ensino, o estímulo intelectual emerge como preponderante uma vez que o objetivo da mesma é atuar como semeadora e 
disseminadora de conhecimentos. Para gerir o conhecimento na forma de criação, aquisição, refinamento, armazenagem, transferência, compartilhamento e utilização, resultando em um desempenho organizacional satisfatório, é necessário estímulo intelectual, conforme visto na figura 1, pág. 35. Nonaka e Takeuchi (1995), ao afirmar que o conhecimento tácito pode ser transferido para o conhecimento explícito através dos quatro processos de socialização, externalização, combinação e internacionalização, coloca o trabalho em equipe em foco, uma vez que esses processos somente serão possíveis na medida que uma equipe estiver sendo motivada, orientada e estimulada intelectualmente para determinadas metas, pelo contrário, não há transferência de conhecimentos e o docente perde seu papel enquanto instrutor, tornando-se apenas um disseminador de informações.

Na análise da Figura 20, 36\% dos estudantes de graduação do $2^{\circ}$ ano, $34 \%$ dos estudantes do $4^{\circ}$ ano e $85 \%$ dos estudantes da pós-graduação avaliaram o docente como fomentador de estímulo intelectual ao escolherem as alternativas Concordo plenamente e Concordo, sendo que $49 \%$ dos estudantes do 2 ํㅡㄴ ano e $52 \%$ dos estudantes do $4^{\circ}$ ano avaliaram 0 docente negativamente nesse item, escolhendo as alternativas Discordo plenamente e Discordo. O estimulo intelectual advindo do docente não resultou em um discurso mais favorável dos estudantes da graduação em relação ao andamento das disciplinas. O que ocorre é que, conforme Polanyi (1958, 1967) argumenta, só sabemos o que sabemos, quando precisamos sabê-lo. Se não há motivação para que o estudante adquira a consciência de que deve transformar o estímulo intelectual em resultados, o estímulo se perde nele mesmo. É importante frisar, desse modo, que o estímulo intelectual deve ser precedido de uma motivação que também seja estimulante. Mesmo havendo o estímulo intelectual, o conhecimento não se transferiu para a grande maioria dos 
estudantes, conforme discurso dos mesmos, que demonstrou insatisfação no ambiente de sala pelos problemas de comunicação enfrentados entre os estudantes e o docente. O membro 2011_SI_G04_Alun03 demonstra bem o cenário enfrentado quando diz em seu discurso:

A disciplina foi mal ministrada. Havia conflito das informações passadas pelo docente. Além disso, nunca ficava claro o que tínhamos de fazer e quais eram os objetivos dos trabalhos. O docente não motivou nem estimulou os estudantes a se interessarem pelo tema.

Seguindo a mesma linha de pensamento, outro estudante declara:

Acredito que a disciplina seria mais estimulante se o docente explicasse um pouco mais os conteúdos que devemos pesquisar. Outro fator que ajudaria seria a entrega da nota dos trabalhos já apresentados (2011_SI_G05_Alun06).

O membro 2011_SAD_G05_Alun02 vai mais fundo na questão afirmando que a maior parte do desenvolvimento do trabalho que seu grupo efetuou foi de forma autodidata, o que remete uma vez mais à dificuldade de se transpor a barreira do tradicional uma vez que inserção do PBL como metodologia visa estimular o estudante como próprio gestor de seu aprendizado, ou seja, torna-lo de certa forma autodidata.

Considerando o tempo (1 semestre), pouca coisa me foi agregado já que o professor não nos introduziu "matéria nova". A maior parte do desenvolvimento do trabalho foi "autodidata". Entretanto, foi um bom teste para se utilizar as ferramentas para a tomada de decisão como o Brainstorm, diagrama de Ishikawa e a árvore de decisão (2011_SAD_G05_Alun02). 
O discurso de outros estudantes, como os vistos a seguir, faz acreditar que grande parte dos estudantes da engenharia não está preparada para ser responsável pelo seu próprio aprendizado, necessitando os mesmos, ainda, da forma tradicional de se transmitir conteúdo, pelo menos nas primeiras aulas, e mais, no momento da quebra do paradigma, que seja feito de forma gradual e com apoio didático.

Precisamos de mais exemplos pois não temos material didático. A importância dada ao Facebook não faz sentido. Explicar melhor como fazer o trabalho ao invés de falar tanto da importância dos SI na sociedade (2012_SI_G02_Alun04).

Não fui estimulada a aprender, assim os conceitos que são muito importantes para o meu futuro ficaram vagos. Apesar de o objetivo do curso ser diferente, sinto que faltou um direcionamento do docente e dos monitores. Gostaria de ter tido mais aulas de programas como o Excel (2012_SI_G06_Alun05).

Acredito que focar mais a disciplina em softwares como o excel e access possam agregar mais valor a vida profissional dos estudantes pois hoje é muito valorizado pelos gestores. O conteúdo sobre esses softwares passados em aula foram abordados muito rapidamente $\mathrm{e}$ podem ser mais aprofundados. Sugiro mudar o relator toda semana pois é importante que todos saibam fazer relatórios que demonstre desempenho e que descreva a reunião. O Facebook ficou sobrecarregado de informações, o que atrapalha na hora de postar e demonstrar opinião sobre 0 tópico (2012_SAD_G01_Alun01).

Aula mais dinâmica e interativa (2012_SAD_G01_Alun01).

O estímulo intelectual por parte do docente, apontado pela maioria dos estudantes como não tendo acontecido nas disciplinas da graduação, remete-o novamente à liderança Laissez-faire. Assim sendo, o estímulo intelectual não gerou 
motivação nem aquisição de conhecimentos em grande escala. Estudantes de disciplinas de que tratavam de assuntos diferentes apontaram os mesmos tipos de problema. A utilização de cases e mais exemplos práticos foi sugerido tanto por um estudante do $2^{\circ}$ ano assim também como por estudantes do $4^{\circ}$ ano de 2011 como forma de captar mais a atenção deles em sala de aula.

Empregar mais "cases" durante as aulas de forma a captar mais a atenção dos estudantes. Esses "cases" devem ser resolvidos pelos estudantes utilizando as ferramentas apresentadas no decorrer da disciplina (2011_SI_G02_Alun01).

A matéria poderia ter mais exemplos para utilizar o processo de tomada de decisão a fim de praticar a pesquisa de informação e a avaliação de riscos (2011_SAD_G03_Alun02).

...Acho que a disciplina ficaria mais interessante se a cada aula tivéssemos que solucionar casos utilizando a ferramenta aprendida e pesquisando como implementar...(2011_SAD_G06_Alun04).

Na visão do estudante 2011_SAD_G04_Alun03, faltou um maior e mais fundamentado embasamento teórico.

Poderia ter sido passado aos estudantes um maior, e mais fundamentado, embasamento teórico... as sugestões de ferramentas a serem utilizadas, o OLAP, se mostraram expostas de maneira desconexa, o que interferiu na aplicação das mesmas para 0 desenvolvimento do trabalho (2011_SAD_G04_Alun03).

Mesmo a ementa da disciplina fornecendo um guia teórico para um correto acompanhamento das aulas, ficou claro que somente a teoria fundamentada em publicações diversas, e não consolidada pelo docente em aula pela transferência de 
conhecimentos tácitos oportunos, não gera novos conhecimentos, ficando as informações desconexas. O elo entre as informações contidas em artigos, livros, jornais e experiências práticas, e os estudantes, deve ser o docente, por meio de uma atitude de estímulo intelectual, mas sem faltar com a motivação necessária. Nas aulas em que houve a possibilidade de se explicar como se aplica na prática os conhecimentos necessários, como aulas de Excel e Access, houve a percepção do estímulo intelectual com geração de motivação. Essas aulas atuaram como catalisadoras da motivação necessária uma vez que gerou um grande índice de satisfação nos estudantes, motivando-os a estudarem mais a fundo sobre tabelas dinâmicas para poderem utilizar em seus futuros ambientes de trabalho. Esses exemplos aplicáveis são vistos como meios de motivação.

\footnotetext{
Gostei muito de ter esta última atividade de dimensionar uma tabela dinâmica, já que é uma ferramenta simples de fácil acesso e realiza várias funções. Acho que alguns exemplos aplicáveis, ou a visualização mais clara de técnicas, métodos e ferramentas de suporte à decisão poderia motivar mais os estudantes (2011_SAD_G06_Alun02).
}

A probabilidade de haver maior interação entre os estudantes e o docente aumentaria se a estratégia de aula tivesse seguido a dessas aulas em específico desde o começo do semestre, podendo a grande maioria da sala ter tido a mesma percepção do membro 2011_SAD_G01_Alun02, que comenta:

Meu repertório cultural aumentou expressivamente no sentido de suporte para tomada de decisão no dia a dia do profissional. Avaliar o avanço da mão de obra Chinesa nos mantém alertas para as dificuldades que enfrentaremos no dia de amanhã... 
Por meio de uma liderança transformacional, em que a motivação e o estímulo intelectual atuem em consoante, o docente pode ter a mesma avaliação em termos dessas dimensões que obteve dos estudantes da pós-graduação, resultando em maior índice de aprendizado por parte dos estudantes da graduação. A observação e o entendimento pelo docente da complexidade do sistema em uma sala de aula, e como as inter-relações estão repercutindo no progresso dos grupos, passa a ser emergencial, uma vez que atuando com um mesmo perfil de liderança em diferentes disciplinas, obteve resultados diferentes em sua avaliação como líder em ambientes híbridos.

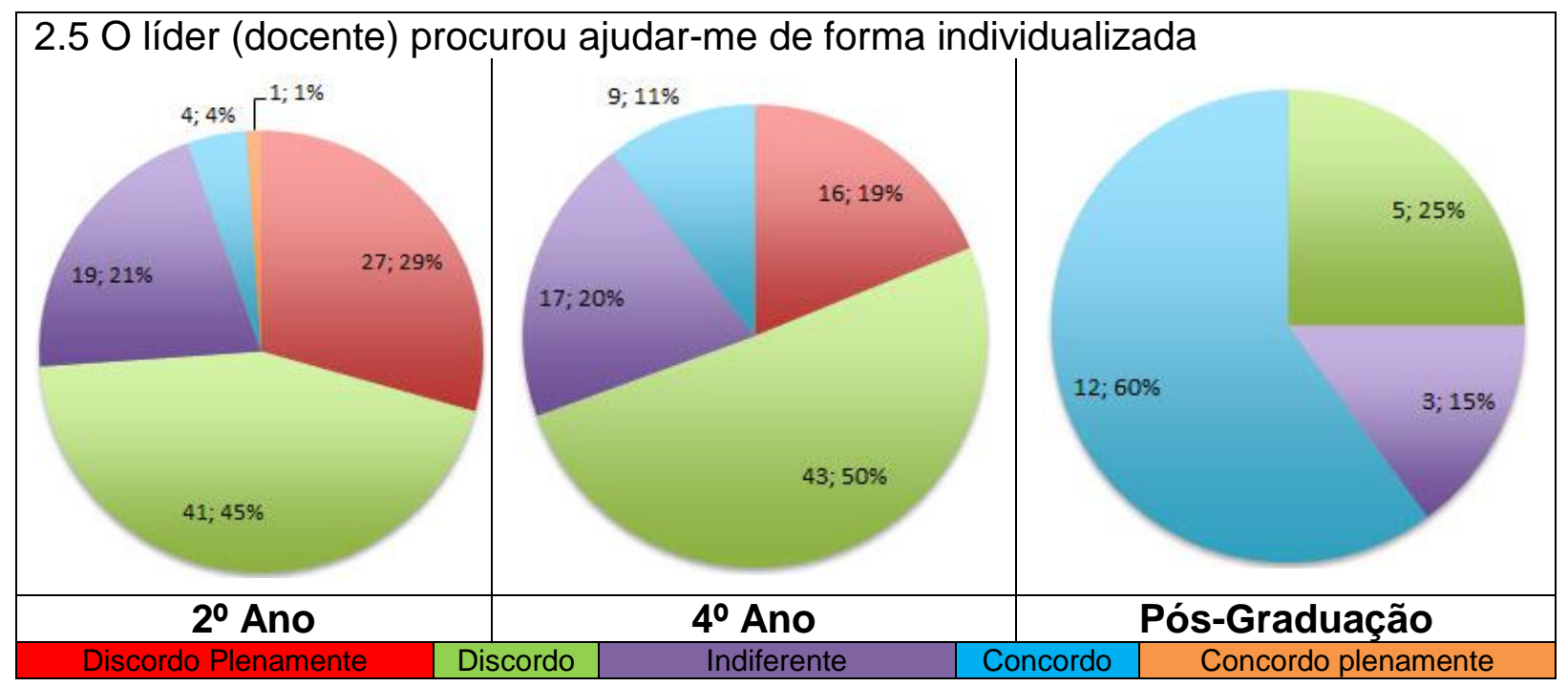

Figura 21 - Análise do perfil de liderança do docente relacionado ao estilo Transformacional pertinente à dimensão da ajuda individualizada

Partindo do discurso do membro 2011_SI_G03_Alun03 e, ao analisar os gráficos correspondentes aos estudantes da graduação, é observado que essa dimensão da liderança transformacional não foi incorporada pelo estilo de liderança do docente nas turmas de graduação, sendo que até os estudantes de pósgraduação apontaram, com $25 \%$ de discordância, que o docente tenha atuado individualmente (Figura 21). 
Não nos foi explicada a matéria nem o seu conteúdo, ficando a cargo de cada estudante pesquisar sobre 0 assunto e a autoaprendizagem (2011_SI_G03_Alun03).

Entre as alternativas Discordo plenamente e Discordo, fica evidente uma lacuna nesse que é um dos grandes alicerces de uma liderança transformacional, que segundo Bass e Avolio (1994), é diferenciada dos outros estilos de liderança pela capacidade dos colaboradores de não apenas atingir as metas propostas pelo líder, mas superá-las. A ausência de uma ação individual do docente no processo ensino-aprendizagem dos estudantes da graduação foi apontada por $78 \%$ dos estudantes do $2^{\circ}$ ano e $69 \%$ dos estudantes do $4^{\circ}$ ano ao optarem pelas alternativas Discordo plenamente e Discordo. A ausência dessa dimensão de liderança vai ao encontro de uma das características de uma liderança Laissez-faire, que indica uma completa liberdade para o grupo ou decisão individual, sem qualquer participação do líder (EAGLY; ENGEN; JOHANNESEN-SCHMIDT, 2003). Analisando o discurso dos estudantes em questões anteriores, fica evidente que a falta desse alicerce, a atuação individual, foi um dos grandes problemas encontrados pelas turmas da graduação, principalmente as do $2^{\circ}$ ano, durante os semestres estudados. A inteligência emocional, por meio de alguns componentes nela integradas, como apreciação e valorização das virtudes pessoais e grupais, encorajamento dos membros das equipes a repercutirem com seus melhores potenciais, alta capacidade de gerir conflitos devido a uma visão holística não apenas do grupo, mas individual a cada membro, pode dar um suporte ao docente para lidar com a complexidade em sala de aula (MURRAY, 2002; NEWCOMBE; ASHKANASY, 2002; NONAKA; TAKEUCHI, 2011; PESCOSOLIDO, 2002; POUNDER, 2001; RANTZ, 2002; ROWLEY; SHERMAN, 2003). A inteligência emocional emerge por meio 
dessa abordagem da liderança transformacional, apoiando a organização para que se mantenha competitiva e atue como fomentadora de melhorias continuas na sociedade do novo milênio (DALAI LAMA XIV, 1999) e uma maneira descomplicada de praticá-la é pela ajuda individualizada. Indo além, em classes com grande número de estudantes, pela impossibilidade de atuação individual na grande maioria das vezes, o docente pode apoiar-se na Teoria da Complexidade (WEAVER, 1948), que entre outros assuntos de interesse, estuda como as relações entre as partes dão origem a comportamentos coletivos de um sistema e como o sistema interage e faz relações com seu ambiente (HAYEK, 1952). Sendo assim, o docente atuando individualmente no líder das equipes de forma assertiva, proativa e motivadora, pode gerar recursos que se estendam aos outros membros da equipe positivamente, pela cadeia de eventos que se seguem a uma atitude motivadora.

Em relação aos estudantes da pós-graduação, novamente a visão do docente pela maioria foi a de um líder proativo $(60 \%$ concordaram com a afirmativa do enunciado da sub-questão 2.5 ), mas a indiferença de $25 \%$ pode indicar que o docente poderia ter ido além. O observado pelo pesquisador foi que o fato de a sala ter apenas 11 membros no ano de 2011 facilitou a atuação individual por parte do docente, mas também foi visto que quando havia inferências, como questionamentos, o mesmo era feito, em grande parte das vezes, a um grupo em específico e não individualmente. As inferências individuais são muito importantes no momento que induz o estudante $a$ ir mais preparado para as aulas. A identificação do perfil de aprendizagem da turma também permite ao docente melhor entender o comportamento dos estudantes e atuar de acordo com o perfil individual ou do grupo, podendo gerar um maior nível de aprendizado no estudante ao respeitar suas peculiaridades (FELDER, 1996; APRENDE..., 2012). A ausência de 
uma atuação individualizada pelo docente enquanto líder gerou uma grande desmotivação, como pode-se observar no discursos escritos que se seguem.

A parte teórica é falha. Um engenheiro precisa de ferramentas e conhecimento técnico além do conhecimento geral. Não posso dizer, ao final da disciplina, que tenho domínio de SI (2012_SI_G01_Alun04).

Levar em consideração a opinião dos estudantes (escutá-los) e sanar as dúvidas de uma forma mais clara. Além disso, melhorar o feedback fornecido durante o semestre (2012_SAD_G03_Alun02).

O grande número de monitores atrapalha a clareza da matéria. Os objetivos de aprendizagem não foram apresentados de forma clara desde o início. 0 método de avaliação da presença não funcionou. As explicações do docente eram muito longas e pouco objetivas, não deixando claras suas expectativas. Sugestões: reduzir o número de monitores; determinar objetivos claros, talvez por meio de ementas; voltar ao método tradicional da chamada; buscar uma objetividade mais específica durante as explicações (2012_SAD_G03_Alun02).

Maior esclarecimento da teoria (2012_SAD_G04_Alun02).

Maior esclarecimento da teoria e esclarecimento dos objetivos dos trabalhos propostos (2012_SAD_G04_Alun03).

Me senti perdido na primeira metade do semestre. Talvez várias metas bem claras com datas específicas seriam mais úteis e também menos informação desnecessária (2012_SAD_G07_Alun02).

Faltou apoio ao longo do semestre na realização do projeto. Grande parte dos grupos ficou perdido em relação ao que deveriam fazer (2012_SI_G07_Alun02).

Faltou mais apoio quanto a execução dos projetos. Os grupos estavam "perdidos" quanto ao que seguir (2012_SI_G07_Alun06). 
Acredito que o trabalho a ser realizado poderia ter sido melhor explicado. Ficamos um pouco perdidos com relação a isso. Acho ainda que os objetivos da disciplina poderiam ter sido melhor explicados no começo da matéria (2012_SAD_G02_Alun03).

Não entendemos o funcionamento da matéria e as expectativas do docente (2012_SAD_G08_Alun01).

Deve haver acompanhamento do docente para cada grupo periodicamente dizendo o que está coerente ou não com os resultados esperados, e indicar o caminho para o trabalho ficar bem feito (2012_SAD_G03_Alun03).

A falta de uma atuação mais individualizada gerou perdas de oportunidades de aprendizagem, e de um aprendizado mais consolidado pelos alunos nos ambientes híbridos.

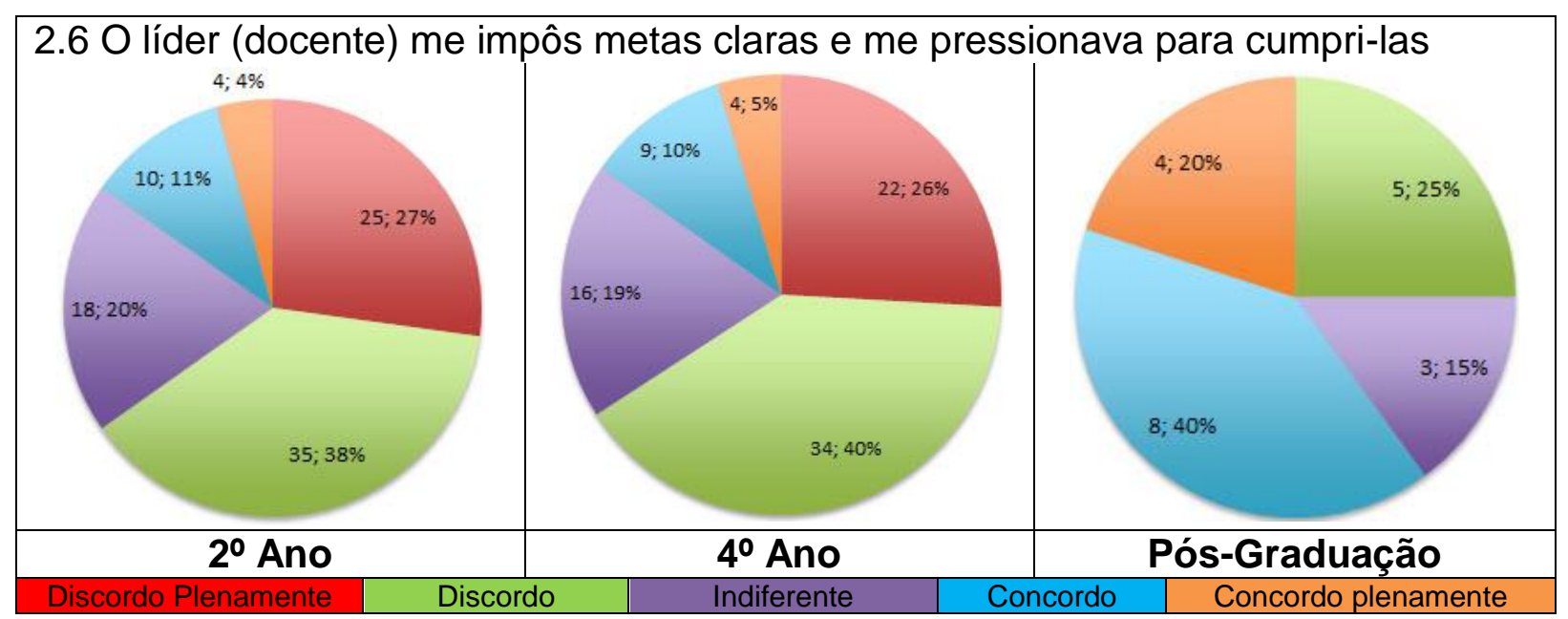

Figura 22 - Análise do perfil de liderança do docente relacionado ao estilo Transacional pertinente ao rigor das cobranças para com os estudantes

Para traçar uma linha de pensamento em relação aos resultados obtidos e observados nos gráficos da Figura 22, é importante frisar que a imposição normalmente leva a um contexto de repressão. Quando observada sob a óptica de uma liderança transacional (EAGLY; JOHANNESEN-SCHMIDT; VAN ENGEN, 2003) 
esse termo direciona-se mais para um entendimento de firmeza. A utilização desse componente, parte do perfil de uma liderança transacional, em alguns contextos é observado como positivo. Em equipes pouco comprometidas, o líder dissemina a incerteza para exercer controle pelo medo e imposição de suas ideias (FINKELSTEIN, 2002). Outras formas de controle são utilizadas na observação de líderes atuando em ambientes complexos. Marion e Uhl-bien (2001) entendem que quando um individuo controla um grupo, o comportamento do grupo pode ser menos complexo que um individuo isoladamente. Líderes utilizam dessa visão para atuarem em ambientes complexos quando um maior controle é necessário e no qual os membros podem desempenhar suas atividades sem necessitarem de criatividade. De acordo com o contexto de cada disciplina, o docente pode agir de forma a priorizar o grupo ou indivíduos isoladamente. A distribuição das tarefas de forma clara deve ser feita para que os estudantes possam ter um entendimento pleno do que deve ser feito. Um líder transacional delega funções de forma clara e pratica a cobrança para que as metas sejam atingidas. $65 \%$ dos estudantes da graduação do $2^{\circ}$ ano e $66 \%$ dos estudantes do $4^{\circ}$ ano apontaram no questionário que Discordam ou Discordam plenamente que o docente tenha agido com essa dimensão da liderança transacional, apontando novamente que o perfil adotado pelo mesmo, consciente ou inconscientemente, foi o de uma liderança Laissez-faire, mesmo com uma percepção menor por parte dos estudantes do $4^{\circ}$ ano e pós-graduação, tendo $15 \%$ dos estudantes da graduação escolhido as alternativas Concordo ou Concordo plenamente que as metas eram claras e havia cobrança pelo docente e $60 \%$ dos estudantes da pós-graduação com a mesma percepção. O discurso dos estudantes da pós-graduação que se seguem remete a uma necessidade imposta por eles 
mesmos de que haja cobrança e metas claras por parte do docente, e isso foi observado até mesmo no discurso de um estudante da pós-graduação:

Foi muito complicado entender o que era para ser feito. A cada semana parecia que novas atividades eram criadas pelo docente e monitores, sem termos entendido ou concluído a etapa anterior. As explicações em aula também não eram claras e/ou dinâmicas, sendo por vezes monótonas, o que acabou gerando desinteresse por parte da sala. Sugestão: rever o método de aula; Objetivos/trabalhos dentro da disciplina; Revisar ementa (2012_SI_G01_Alun01).

A disciplina é complicada e não foi muito bem conduzida. Deveria haver uma forma mais eficiente de transmitir o conhecimento necessário (2012_SI_G01_Alun02).

Repensar a disciplina. Ninguém sabe o que faz, ninguém entende, ninguém aprende. Falta muita clareza (2012_SI_G01_Alun03).

Exemplos mais completos; Parte teórica mais aprofundada; Definição CLARA do que seria avaliado (2012_SI_G01_Alun03).

Mais explicações teóricas e exemplos mais ricos e esclarecedores (2012_SI_G02_Alun04).

Acredito que a disciplina deva ser melhor explicada no início do curso. $\mathrm{Na}$ minha opinião os objetivos não foram explicitados de modo claro, e pontos importantes foram descobertos no meio do curso causando um pouco de alvoroço no grupo (2012_SI_G03_Alun04).

Explicar melhor como a disciplina funcionará logo no começo, e deixar claro o que está sendo avaliado, e o que aprenderemos com ela (2012_SI_G03_Alun05).

Falta de atividades concretas; Excessiva importância dada ao Facebook; Elaborar melhor os projetos antes de exigí-los, ou seja, explicações claras da execução do mesmo (2012_SI_G04_Alun01). 
Estabelecer tarefas claras e com prazo definido (avaliar o produto final e não pedaços semanais); Aprender teoria de SI e não apenas realizar trabalhos com temas aleatórios; Clareza nas explicações (em cada aula o projeto mudava o estilo e o "como fazer") (2012_SI_G04_Alun02).

Definição clara das tarefas do curso no início, e não no decorrer. Tornar a discussão do Facebook espontânea e não dependente de nota, o que torna a discussão forçada (2012_SI_G06_Alun01).

Os objetivos da disciplina não me pareceram claros, e a sala não soube, então, priorizar as atividades dentro da disciplina. Na minha opinião o docente não soube tirar dúvidas efetivamente e, por isso, tivemos que saná-las com outros docentes, o que considerado errado (pois há ainda monitores). Ainda, acho que não fomos ouvidos (apenas consultados) em relação a melhoras na disciplina, e muitas vezes o docente e os monitores foram grosseiros com nossos questionamentos (2012_SI_G06_Alun04).

Faltou certa clareza em diversos processos durante 0 curso (2012_SI_G07_Alun07).

Poderia ter havido um maior esclarecimento de como fazer o trabalho e uma melhor explicação dos métodos de avaliação (2012_SAD_G02_Alun02).

Precisamos ter mais exigência nas atividades, cobrar mais dos estudantes (definir bem as metas da disciplina, com objetivos e "resultados" concretos (2011_SAD_PósG01_Alun01).

Maior cobrança de resultados dos trabalhos dos grupos (2011_SAD_PósG01_Alun02).

A necessidade de maior cobrança também foi observada no discurso dos membros 2011_SAD_G02_Alun02 e 2011_SAD_G05_Alun03 do 4ํano.

Acredito que poderia haver maior rigidez no acompanhamento de todas as etapas do trabalho principal, de forma a "forçar" o aprendizado dos estudantes, evitando que estes se distraiam e deixem o trabalho para última 
hora. Acredito também que poderia haver um maior uso do Moodle (2011_SAD_G02_Alun02).

Poderia haver mais cobrança quando for pedida alguma entrega parcial (2011_SAD_G05_Alun03).

Metas claras e cobrança passam a ser requisitos de uma liderança efetiva pelo docente em sala de aula na engenharia, agregando valor a outras dimensões, que se bem balanceadas, podem repercutir positivamente na forma de aprendizado.

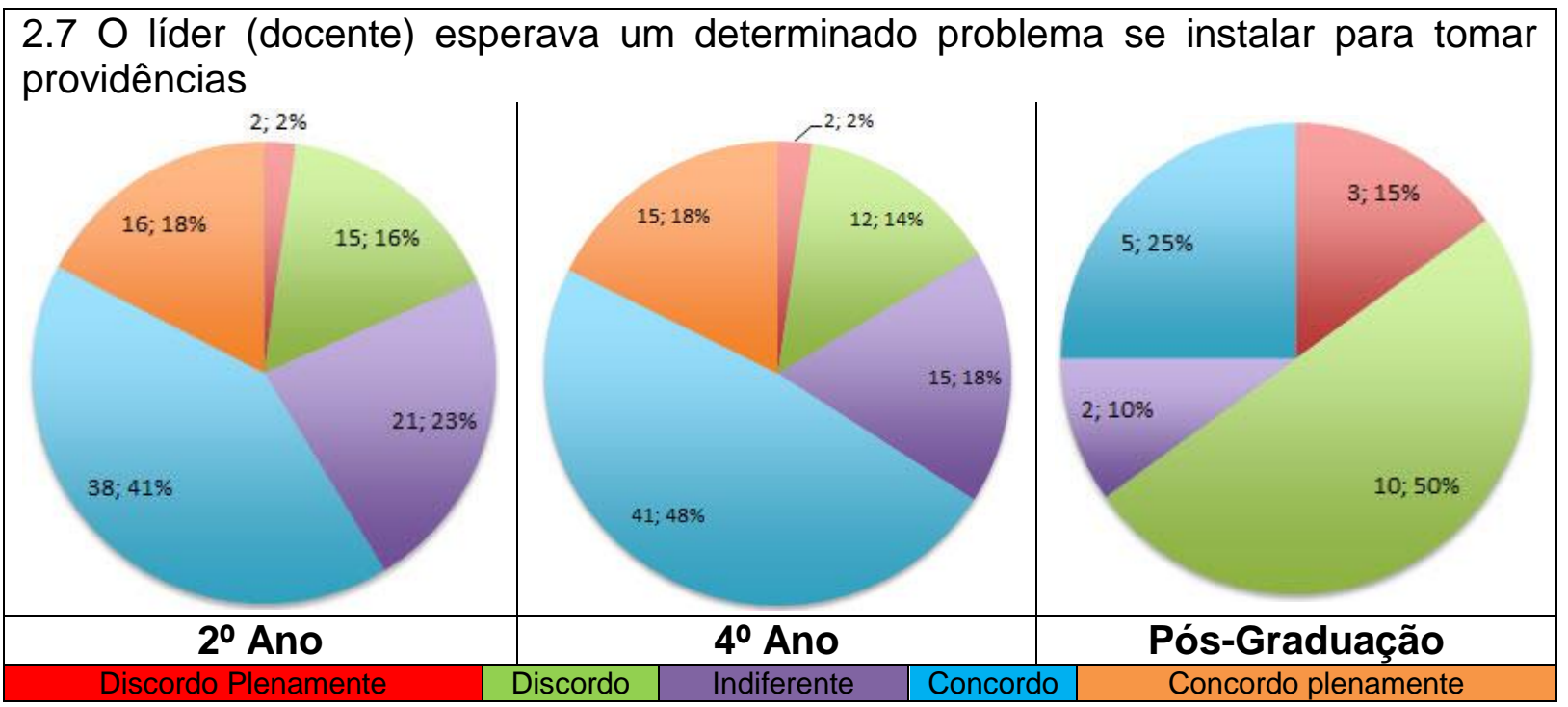

Figura 23 - Análise do perfil de liderança do docente relacionado ao estilo Transacional pertinente à dimensão gerenciamento por Exceção Passiva

Como já visto, liderança por exceção-passiva é uma dimensão do perfil de liderança transacional que tem como premissa a ausência de atitudes do líder até que um problema se externalize (BASS; STEIDLMEIER, 1999). Nessa dimensão de liderança, o líder aguarda um determinado problema se instalar para tomar alguma providência. Essa atitude pode ser positiva se o líder tiver conhecimento da complexidade envolvida em determinados problemas e permitir, assim, que o grupo haja com o intuito de o mesmo procurar uma solução. Agir passivamente pode 
desenvolver a criatividade em uma equipe e fazer com que líderes natos emerjam. No momento em que o docente como líder não tem a percepção de que algo está acontecendo, induzindo uma equipe ao erro e ao retrabalho por omissão, ele passa da dimensão de liderança transacional para a Laissez-faire (EAGLY; ENGEN; JOHANNESEN-SCHMIDT, 2003).

Quando analisada a Figura 23, nota-se que a percepção de uma atitude passiva foi identificada por $59 \%$ dos estudantes do $2^{\circ}$ ano da graduação e $66 \%$ dos estudantes do $4^{0}$ ano, que optaram pelas alternativas Concordo e Concordo plenamente enquanto houve uma discordância de $65 \%$ dos estudantes da pósgraduação, $18 \%$ nos estudantes do $2^{\circ}$ ano e $16 \%$ dos estudantes do $4^{\circ}$ ano, que optaram por Discordo plenamente e Discordo. Se essa questão fosse analisada isoladamente, poderia levar o pesquisador a questionar se o docente estava agindo em prol da equipe aguardando a manifestação de atitudes criativas e a alteração do status quo da mesma, ou agindo como Laissez-faire. Uma vez que outras questões já analisadas demonstraram que não houve interferência do docente nos grupos, ou individualmente, atitude notada mais nitidamente pelos estudantes da graduação, a liderança por exceção passiva pode ser descartada quando os gráficos anteriormente estudados juntam-se ao discurso dos estudantes e somam-se às observações do pesquisador em sala.

Um dos estudantes da pós-graduação, membro 2011_SAD_PósG02_Alun01, questiona a método utilizado pelo docente ao afirmar que alguns assuntos discutidos em aula não eram compatíveis com o tema da disciplina, evidenciando que o docente pode ter atuado de forma passiva em identificar esse problema. Em sistemas complexos, seguir uma linearidade extrema pode ser motivo de perda de oportunidades de aprendizagem, uma vez que assuntos incompatíveis a uma 
determinada pessoa pode se relacionar com a realidade de outras determinadas pessoas de acordo com a experiência de vida de cada um. Regine e Lewin (2000) explicam que, em termos mais simples, a teoria da complexidade se afasta da linearidade e do ponto de vista mecanicista do mundo, onde simplesmente há uma causa e um efeito. Segundo os pesquisadores, soluções são procuradas para explicar fenômenos físicos e sociais como meio de apoiar uma perspectiva do mundo como não linear e orgânico, caracterizado pela incerteza e imprevisibilidade. Assim sendo, uma vez identificado que ambientes híbridos são um sistema complexo, tema que está demandando muita atenção por parte de pesquisadores a nível global, cabe ao docente explorar alternativas de aula, mesmo que saiam da ementa da disciplina, mas que se liguem posteriormente aos objetivos que ele quer alcançar, conectando-se novamente à mesma. Uma atitude Laissez-faire não se encaixa na realidade dos sistemas complexos uma vez que a falta de pró-atividade pode gerar desmotivação e desinteresse dos estudantes. Cabe ao docente ser mais um elo entre os membros em sala, e não um elo separado de uma corrente, com uma atitude alienada, não participativa. A forma do docente enfrentar os desafios foi encarada pelos estudantes da pós-graduação como proativa uma vez que identificaram no mesmo um líder atuante. Com $65 \%$ de uma visão que o docente percebia dificuldades inerentes às equipes e agia antes que um problema se instalasse demonstra uma dimensão de liderança transacional por exceção-ativa. Uma vez mais é demonstrado que estudantes da graduação e da pós-graduação possuem capacidades adaptativas diferentes, quando verificado pelo pesquisador que o estilo de liderança que o docente utilizou em todas as disciplinas foi o mesmo, mas com resultados opostos. Não obstante, uma vez mais é evidenciada a 
importância da inteligência emocional no momento de se identificar os contextos de aula e suas nuances.

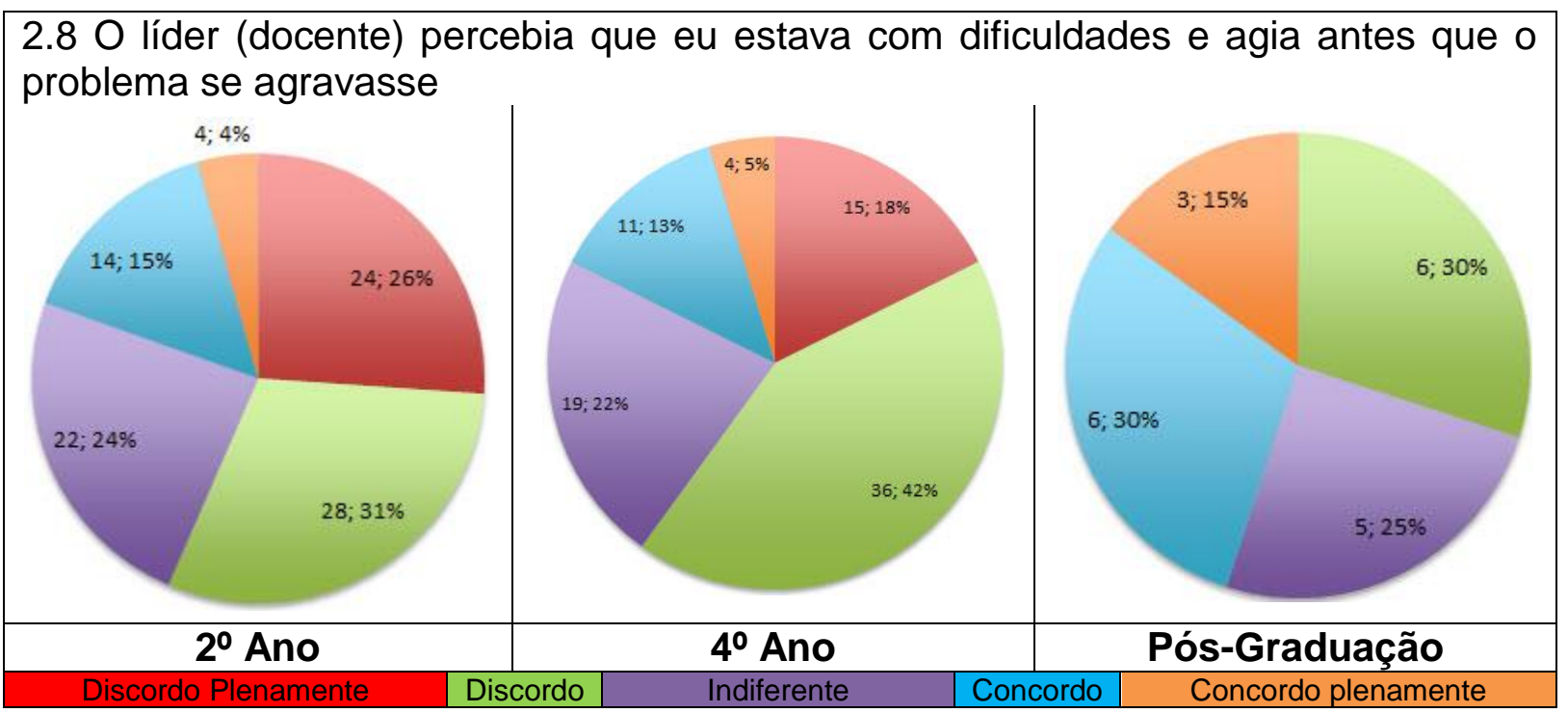

Figura 24 - Análise do perfil de liderança do docente relacionado ao estilo Transacional pertinente à dimensão gerenciamento por Exceção Passiva

Como analisado na teoria, o líder sábio (NONAKA; TAKEUCHI, 2011) possui uma visão global e identifica cada contexto de ação, e o contexto é fator impactante no desempenho de equipes. Nonaka (1991) afirma que as pessoas não recebem um novo conhecimento de forma passiva, mas que o interpretam ativamente, adaptando-o às suas próprias situações e perspectivas. Assim, fica claro que sem uma visão holística e sabedoria no momento das inferências, o nível de aprendizado alcançado pelos estudantes pode não ser satisfatório uma vez que pode ficar relegado a contextos de difíceis interpretações pelos mesmos. Assim, a análise deste conceituado pesquisador da área de gestão do conhecimento de que o que faz sentido em um determinado contexto pode mudar ou até mesmo perder 0 sentido quando comunicado a pessoas de contexto diferente, remete o docente a ir em busca dessa visão global se o seu objetivo maior for o de não somente alcançar uma meta, mas ultrapassá-la por uma liderança transformacional (BASS; AVOLIO, 
1994), eliminando a confusão contínua quando um novo conhecimento é difundido em uma organização, cabendo ao líder direcionar essa confusão para a criação do conhecimento (NONAKA, 1991).

Atuar na complexidade de uma sala de aula analisando e interpretando o ambiente, agindo proativa ou corretivamente logo no início de um evento passa a ser um requisito fundamental de um docente como líder na disseminação do conhecimento, uma vez que como já visto, pequenas mudanças nas condições iniciais produziam grandes alterações no resultado a longo prazo (LORENZ, 1963).

Ao analisar a Figura 24 relacionada à questão se 0 docente percebia se 0 estudante estava com dificuldades e agia antes que o problema se agravasse, é analisado, além da visão holística, se houve a atuação do docente em uma dimensão da liderança transacional denominada liderança por exceção-ativa, que é aquela que se difere da liderança por exceção-passiva pelo timing da ação do líder, que na ativa acontece antes que um determinado problema se instale (HOWELL; AVOLIO, 1993). Entre os estudantes das disciplinas pesquisadas, $19 \%$ dos estudantes do $2^{\circ}$ ano, $18 \%$ dos estudantes do 4 - ano e $45 \%$ dos estudantes da pósgraduação optaram por Concordo plenamente e Concordo, sendo que 57\% e $60 \%$ dos estudantes do $2^{\circ}$ e $4^{\circ}$ anos respectivamente optaram por Discordo plenamente e Discordo (estudantes da pós-graduação não optaram por nenhuma dessas alternativas). O fenômeno da atuação do docente em seu estilo de liderança foi novamente observado como predominantemente Laissez-faire pelos estudantes da graduação quando discordaram que o docente tenha sido proativo ao identificar e agir quando problemas começaram a surgir no decorrer da disciplina, com maior índice de discordância pelos estudantes do $2^{\circ}$ ano. Uma atuação mais proativa foi identificada por estudantes do $4^{\circ}$ ano em maior grau possivelmente devido às 
inferências no final da disciplina, quando o docente incentivou-os intelectualmente, gerando determinado grau de motivação por meio do estudo de exemplos práticos, como uma tabela dinâmica, observado como muito positiva no discurso dos estudantes analisados na sub-questão 2.4. Os estudantes da pós-graduação novamente perceberam que seus papéis poderiam ser executados mesmo sem uma liderança proativa e participativa, uma vez que as inferências do docente advinham mais do conteúdo trazido em sala do que o disseminado em seu portfólio de conhecimentos. Nenhum estudante da pós-graduação apontou o docente com a dimensão de liderança por exceção-passiva, mas $25 \%$ se disseram indiferentes, alternativa que provavelmente não seria escolhida se houvesse uma pró-atividade nítida.

Exemplos de que o docente não atuou como um líder transacional na dimensão liderança por exceção-ativa está no discurso dos estudantes a seguir. 0 membro 2011_SI_G05_Alun01 apontou que, na disciplina do $2^{\circ}$ ano, a ementa da disciplina foi esquecida.

O Cronograma proposto no início do semestre não foi seguido (2011_SI_G05_Alun01).

No discurso do membro 2011_SAD_G04_Alun03 fica evidenciado que se uma liderança por exceção-ativa houvesse acontecido, a confusão durante a disciplina poderia ter sido combativa. Se voltarmos novamente ao paradigma da Teoria da Complexidade, uma ação no início da disciplina poderia repercutir positivamente no decorrer da mesma.

O grupo se sentiu um pouco perdido no início e no decorrer da disciplina (2011_SAD_G04_Alun03). 
A não observância por grande parte dos estudantes da graduação de uma pró-atividade na identificação e combate a problemas por parte do docente, remete o mesmo a um estilo Laissez-faire, que ao atuar em paralelo com o PBL gera grande confusão em ambientes híbridos, como observado no discurso dos estudantes abaixo.

Houve excesso de informação no Facebook, o que dificultava uma leitura crítica e sistemática (2012_SI_G01_Alun03).

Tive dificuldades em me adequar ao novo modelo de ensino, o que fez com que essa mudança de comportamento me custasse energia considerável. Acredito que conforme mais disciplinas aderirem ao novo modelo, ficará mais natural ao estudante de engenharia de produção a adoção do PBL. A disciplina tem dificuldade de alcançar sua meta estando "ilhada" no contexto do programa do curso (2012_SAD_G07_Alun01).

Embora a metodologia de ensino pareça ser a mais próxima do ideal que se vê no departamento, os sistemas utilizados trazem muito mais problemas que vantagens. O sistema de comunicação desorganizado e sem nenhuma integração, associado ao sistema de avaliação nada eficiente, chega a ser desestimulante. Não há ferramenta de gestão para que o líder consiga desempenhar seu papel em trabalhos não presenciais (Ex: cobrar dos membros que postem suas avaliações). Minha sugestão é a elaboração de um sistema que integre Moodle, Facebook e, possivelmente, um sistema de fóruns (independente do Moodle). Infelizmente, por mais impressionante que a metodologia seja em teoria, ela nunca trata os resultados esperados se os sistemas utilizados não forem adequados. Vale ressaltar que a presença dos monitores reduz muito os efeitos da falta de integração e adequação dos sistemas utilizados. Digamos que eles corrigem à mão (no dia-a-dia) o que falta/faltou no modelo (2012_SI_G08_Alun01).

Acredito ter aprendido pouco sobre sistemas de informação. Apesar de ter realizado corretamente as tarefas e com elas ter aprendido, imagino que 0 resultado final foi pouco expressivo. Se entrasse agora no mercado de 
trabalho e dependesse do meu conhecimento de SI penso que seria engolido. Grande parte disso deve-se ao mal andamento da disciplina. As discussões em mídias sociais raramente acrescentavam algo (na sua maioria foram superficiais e de pouca relevância). O docente não conseguia sanar as duvidas efetivamente e muitas vezes posicionou-se de forma evasiva em relação a elas. Aprecio o sistema de ensino que tentou ser aplicado, mas vejo que, evidentemente, ele não trouxe bons resultados (2012_SI_G04_Alun04).

$\mathrm{O}$ docente não conseguiu tirar as duvidas eficazmente. Faltou direcionamento na matéria e entendimento específico sobre o trabalho por parte dos monitores (2012_SI_G06_Alun02).

Creio que os estudantes da USP não estejam preparados para este método. Facebook é uma ferramenta para lazer e não pode ser usada como critério de avaliação. Esta disciplina ficaria muito mais interessante se fosse expositiva e tivesse cases em aula e visitas técnicas (2012_SI_G06_Alun03).

A disciplina teve um bom andamento, apenas acredito que poderia ter sido realizado um maior apoio aos estudantes em relação à realização do projeto do sistema. Creio que as tarefas que deveriam ser realizadas deveriam ser avisadas de uma forma diferente, além do Facebook (2012_SI_G07_Alun01).

O conhecimento se consolidaria se fizéssemos aulas teórico-práticas. Ex: Primeira hora de aula se fala sobre o tema da aula e na segunda aplicamos os conceitos (2012_SI_G08_Alun05).

Acredito que o uso de mídias sociais como Facebook para um grupo tão grande como foi introduzido permitiu um acumulo muito grande de informações, mas esse excesso de informações levou que grande parte dos estudantes não participassem de forma efetiva e que agregasse valor nas discussões ao grupo. Um maior foco em Softwares como o Excel e Access também seria de grande valia para o desenvolvimento da disciplina (2012_SAD_G01_Alun02).

Maior acompanhamento dos projetos e focar mais em ferramentas como Excel e Access (2012_SI_G08_Alun05). 
Acredito que a disciplina tenha sido bem conduzida e foi possível explorar assuntos relevantes para nossa profissão. Entretanto, acredito que é necessário ter um direcionamento maior por parte do docente nas atividades propostas. Sei que faz parte do método PBL dar liberdade aos estudantes de explorar os assuntos relacionados, mas é necessário nortear melhor o aprendizado e acompanhar a evolução dos estudantes (2012_SAD_G02_Alun01).

Desenvolver um conteúdo programático para auxiliar os estudantes estudarem antes das aulas (2012_SAD_Pós_G01_Alun04).

Com relação ao Moodle, faltou anexar artigos (textos) da disciplina para termos uma facilidade de acesso rápido. Logicamente, a pesquisa em sites de pesquisa são de extrema importância para buscas; Houve pouco uso do Facebook, ou acompanhamento (inclusive eu); Cadastrar e-mail e telefone dos estudantes no Moodle, onde há uma maior integração, contato e acompanhamento (2012_SAD_Pós_G02_Alun04).

Por outro lado, as inferências do docente foram analisadas como positivas pelos estudantes da pós-graduação, o que valida a importância da visão sistêmica e ação local que o docente deve apresentar em cada contexto. 


\subsection{Percepção dos estudantes em relação às mídias sociais utilizadas nos anos de 2011 e 2012 e influências da liderança do docente na condução das disciplinas ministradas com o método PBL}

\section{Análise da utilização do Wiggio em 2011 por estudantes da Pós-graduação}

O Wiggio, ferramenta de groupware utilizada para a interação virtual em 2011 por estudantes da pós-graduação, cujas funcionalidades estão presentes na Figura 26, foi criado em janeiro de 2008 por dois estudantes diplomados da Cornell University, uma universidade privada situada em Ithaca, Nova lorque, Estados Unidos da América, com o intuito de aperfeiçoar as responsabilidades do trabalho em grupo.

\footnotetext{
"Começamos o Wiggio com base em nossas próprias frustrações com as correntes de e-mail sem fim, usando cinco sites diferentes para cinco funções diferentes, e todos os outros aborrecimentos associados ao trabalho em grupos. Estávamos cansados de enviar e-mails e utilizar cinco diferentes sites para definir um horário de reunião. Estávamos cansados daquele cara que simplesmente nunca sabia onde e quando seria a próxima reunião. Estávamos cansados de múltiplas listas, livros de contato, listas telefônicas e incompatibilidades. Queríamos tudo em apenas um lugar, e nós queríamos que fosse simples" (WIGGIO, 2011, tradução livre).
}

A utilização do Wiggio na pós-graduação em 2011 vai ao encontro de novas formas de se trabalhar em equipe buscada por organizações de vários fins. Interpretar como as integrações ocorrem neste ambiente permite criar paralelos com comportamentos presenciais, permitindo com que os gestores das disciplinas adquiram um Know-how mais apurado no momento da aquisição de novos conhecimentos tácitos e explícitos no gerenciamento de equipes virtuais. 
Qual seu grau de motivaçắo $\mathrm{em}$ trabalhar em um Ambiente Virtual de

Colaboração - Pré-semestre 2011

\begin{tabular}{c|c|c|}
\hline Nota & Qt & $(\%)$ \\
\hline 8 & 3 & $50 \%$ \\
\hline 9 & 1 & $16,7 \%$ \\
\hline 10 & 2 & $33,3 \%$ \\
\hline
\end{tabular}

Grau de motivaçầo em trabalhar em um Ambiente Virtual de Colaboração - Póssemestre 2011

\begin{tabular}{|c|c|c|}
\hline Nota & Qt & $(\%)$ \\
\hline 6 & 3 & $50 \%$ \\
\hline 7 & 1 & $16,7 \%$ \\
\hline 8 & 2 & $33,3 \%$ \\
\hline
\end{tabular}

Figura 25 - Grau de motivação dos estudantes de pós-graduação $\mathrm{cm} 2011$ antes e depois de trabalharem no Wiggio
O pesquisador entrou em contato com os responsáveis pelo Wiggio e obteve suporte da equipe, estabelecida em Cambridge, Massachusetts, Estados Unidos da América. Foi criado um vínculo de cooperação, em que o suporte técnico se dava em um curto período de tempo por meio do Skype ou via e-mail, em contato do tutor do ambiente (esse pesquisador) com o engenheiro chefe da ferramenta. Em uma análise do índice de motivação dos estudantes de pós-graduação em

2011 em uma escala de 1 a 10 antes e depois de trabalharem no Wiggio observa-se, comparando-se os dados presentes na Figura 25, que houve uma redução no índice de motivação, muito disso pela inabilidade de trabalharem no ambiente pela falta de um treinamento mais intensivo no uso das ferramentas nele presentes. Entre outras eventos estudados, como as ferramentas mais utilizadas no ambiente virtual de colaboração (Figura 26), as três que obtiveram um maior índice de uso, com 83,3\% (criação de tópicos, recebimento de e-mails da lista fornecida pelo groupware e upload de arquivos) indicam uma propensão da equipe em convergir, para um ambiente único, as tarefas a serem realizadas, mesmo analisando-se que o treinamento da equipe no ambiente virtual não foi devidamente oferecido por parte do tutor do groupware, item indicado como primordial pela equipe conforme observado na Figura 27, com 83,3\% de importância. 


\begin{tabular}{|c|c|}
\hline Possibilidades da mídia social Wiggio que experimentei & Porcentagem (\%) \\
\hline Criação de tópicos & $83,3 \%$ \\
\hline Lista de e-mails do grupo & $66,7 \%$ \\
\hline $\begin{array}{l}\text { Recebimento de mensagens postagens no ambiente diretamente } \\
\text { pelo e-mail }\end{array}$ & $83,3 \%$ \\
\hline $\begin{array}{l}\text { Configuração do Perfil (Nome, E-mail, Telefone, Skype, } \\
\text { Facebook, Twitter, Blog }\end{array}$ & $50 \%$ \\
\hline Upload de arquivos & $83,3 \%$ \\
\hline Criação de documentos em DOC e XML & $33,3 \%$ \\
\hline Edição de documentos & $50 \%$ \\
\hline Compartilhamento de links & $66,7 \%$ \\
\hline Upload de vídeos & $16,7 \%$ \\
\hline Envio de e-mail para os colegas direto do ambiente & $33,3 \%$ \\
\hline Envio de mensagem por texto & $16,7 \%$ \\
\hline Ferramenta de votação & $16,7 \%$ \\
\hline Pasta de armazenagem de arquivos & $16,7 \%$ \\
\hline Possibilidade de criação de subpastas & $16,7 \%$ \\
\hline Possibilidade de envio de mensagens individuais & $16,7 \%$ \\
\hline Possibilidade de envio de mensagens para o grupo & $33,3 \%$ \\
\hline Possibilidade de criação de subgrupos & $16,7 \%$ \\
\hline $\begin{array}{l}\text { Possibilidade de convidar por e-mail participantes externos para } \\
\text { tópicos específicos }\end{array}$ & $16,7 \%$ \\
\hline $\begin{array}{l}\text { Para interação entre a equipe utilizei outras soluções } \\
\text { externamente ao ambiente }\end{array}$ & $83,3 \%$ \\
\hline
\end{tabular}

Figura 26 - Ferramentas mais utilizadas no Wiggio em 2011 por alunos da pós-graduação

Esses recursos poderiam ser utilizados separadamente em soluções consolidadas como o Google, que por meio do lançamento de um novo serviço em Julho de 2011 incorporou suas ferramentas em uma única solução chamada Google+, definida pelo Google como uma camada social e não uma rede social tradicional. Essa tendência de migração para o ambiente virtual se contradiz com outro item apontado pelos estudantes como fonte de comunicação, que foram as soluções externas como o Skype, Facebook, o Google Docs, E-mails diretos e MSN. 


\begin{tabular}{|l|c|c|}
\hline $\begin{array}{l}\text { Atributos essenciais do líder para atuar em Ambientes } \\
\text { Virtuais }\end{array}$ & Qt de estudantes & Porcentagem (\%) \\
\hline Comprometimento & 3 & $50 \%$ \\
\hline Motivação inspiradora & 4 & $66,7 \%$ \\
\hline Crenças, valores e atitudes & 3 & $16,7 \%$ \\
\hline Permissão para o autogerenciamento & 2 & $50 \%$ \\
\hline $\begin{array}{l}\text { Elogios e recompensas quando os objetivos são } \\
\text { alcançados }\end{array}$ & 2 & $33,3 \%$ \\
\hline Estimulação intelectual & 2 & $33,3 \%$ \\
\hline Conhecimento de TI & 2 & $33,3 \%$ \\
\hline $\begin{array}{l}\text { Ponderação na escolha dos módulos da interface a serem } \\
\text { priorizadas no ambiente virtual }\end{array}$ & 3 & $33,3 \%$ \\
\hline Reforço positivo, como elogios e recompensas & 3 & $50 \%$ \\
\hline Cobrança constante por resultados & 5 & $50 \%$ \\
\hline Treinamento da equipe na utilizaça do ambiente & 2 & $83,3 \%$ \\
\hline Ética & 1 & $33,3 \%$ \\
\hline Empatia & 1 & $16,7 \%$ \\
\hline Interferência pessoal no ambiente virtual & 4 & $16,7 \%$ \\
\hline Feedbacks constantes & 2 & $66,7 \%$ \\
\hline Visão holística & 1 & $33,3 \%$ \\
\hline Punir com o intuito de corrigir & $16,7 \%$ \\
\hline
\end{tabular}

Figura 27 - Características de liderança a serem incorporadas pelo docente em um ambiente virtual de colaboração. Cada estudante pôde escolher até 7 (sete) atributos

Outras ferramentas que poderiam ter otimizado o processo foram descartadas, como as que aparecem com $16,7 \%$ de utilização. $O$ fato das ferramentas de groupware não terem sido exploradas com maior ênfase converge novamente para a análise da Figura 27, que indica com $66,7 \%$ que duas atitudes podem não ter sido incorporadas pelo docente, de forma intencional, na condução da disciplina: Motivação e Feedbacks constantes, seguidas com $50 \%$ de uma cobrança mais consistente por produtividade no ambiente, reforço positivo em relação à importância da utilização da ferramenta e comprometimento em relação ao seu papel frente a equipe quanto a utilização das mídias sociais inseridas no ambiente virtual. Alguns dados, apontados como não prioritários, de certa forma surpreenderam ao pesquisador. Aparecendo com $16,7 \%$, as crenças, valores e atitudes, além da empatia demonstrada pelo 
docente não interferiam no andamento dos desafios. Com 16,7\%, possíveis punições, mesmo com o intuito de corrigir, e a interferência no ambiente são fontes de frustração e falta de comprometimento da equipe. O perfil de liderança na condução de uma disciplina de pós-graduação, tendo como suporte um groupware, emergiu como fator crítico de sucesso na engenharia de produção na pósgraduação, em disciplinas de 2011. Identificar as características do líder que podem aprimorar ou comprometer o bom andamento de uma disciplina em um ambiente virtual de colaboração torna-se emergencial. O impacto que essas características representam na condução de uma disciplina na engenharia refletem nos resultados finais da disciplina e no aprendizado. Sem essas percepções do docente como um líder transformacional, a universidade pode subutilizar ferramentas de $\mathrm{TI}$ e o potencial dos próprios docentes e os seus estudantes. Capacitar o docente como líder transformacional pode gerar vantagem competitiva para a universidade.

Como se pode observar em relação aos resultados quanto às mídias sociais, muito do que se espera em termos de produtividade de uma equipe trabalhando em um ambiente virtual de colaboração advém da interface amigável e aspectos de liderança por parte do docente, para que o groupware seja mais bem utilizado pelos estudantes, que se bem instruídos podem usufruir da maior parte dos recursos das ferramentas sociais presentes nestes ambientes. Quando analisado por 6 (seis) estudantes de Pós-graduação no final do semestre de 2011 em primeiro lugar em um Ranking dos fatores que mais influenciaram no trabalho colaborativo está a interface amigável e o entendimento da Tecnologia da Informação e Comunicação pelo docente (Figura 28), que permite a ele corretas delegações ao tutor, para que possíveis dificuldades inerentes ao ambiente virtual possam ser identificadas e combatidas, com o propósito de se obter a melhor solução. 


\begin{tabular}{|c|c|c|}
\hline Item & Contagem geral $^{1}$ & Ranking geral \\
\hline $\begin{array}{l}\text { A interface amigável e o entendimento da TIC } \\
\text { pelo docente enquanto lider fez com que meu } \\
\text { trabalho rendesse melhores resultados }\end{array}$ & 42 & 1 \\
\hline $\begin{array}{l}\text { A ética da liderança foi fator impactante nos meus } \\
\text { resultados frente aos desafios }\end{array}$ & 41 & 2 \\
\hline $\begin{array}{l}\text { O contexto foi fator limitante de desempenho e o } \\
\text { líder é quem deveria ter identificado os problemas } \\
\text { e corrigido-os }\end{array}$ & 41 & 3 \\
\hline $\begin{array}{l}\text { Crenças, valores e atitudes do lider fez com que } \\
\text { eu desempenhasse meu trabalho com mais } \\
\text { qualidade }\end{array}$ & 38 & 4 \\
\hline $\begin{array}{l}\text { Já trabalhei com líderes proativos e observei } \\
\text { mudanças de comportamento dentro de meu } \\
\text { ambiente de trabalho }\end{array}$ & 36 & 5 \\
\hline $\begin{array}{l}\text { Os responsáveis pela disciplina atuaram como } \\
\text { líderes transformacionais }\end{array}$ & 35 & 6 \\
\hline $\begin{array}{l}\text { Vejo que a visão holística de cada membro da } \\
\text { equipe por parte do lider gerou motivação para } \\
\text { que eu trabalhasse de forma mais proativa }\end{array}$ & 32 & 7 \\
\hline O líder sempre foi o docente & 26 & 8 \\
\hline $\begin{array}{l}\text { Em sala, a liderança transacional sempre obteve } \\
\text { índices de desempenho acima de uma liderança } \\
\text { transformacional }\end{array}$ & 22 & 9 \\
\hline $\begin{array}{l}\text { Enfrentei conflitos dentro da minha equipe que } \\
\text { foram identificados e tratados por um lider } \\
\text { transformacional que, por meio da observação e } \\
\text { interferência no ambiente tradicional e/ou virtual, } \\
\text { reverteu a situação }\end{array}$ & 16 & 10 \\
\hline \multicolumn{3}{|c|}{$\begin{array}{l}{ }^{1} \text { A pontuação é um cálculo ponderado. Itens ranqueados em primeirolugar são mais valorizados do que } \\
\text { as linhas seguintes, sendo a pontuação a soma de todas as escolhas feitas pelos estudantes, que podiam } \\
\text { escolher } 7 \text { (sete) itens cada um }\end{array}$} \\
\hline
\end{tabular}

Figura 28 - Ranking das percepções dos estudantes de pós-graduação em 2011 relacionadas à liderança do docente

A ética aparece em segundo lugar no Ranking, demonstrando que o docente necessita ter consciência de seus atos, uma vez que os mesmos estão sendo observados, tornando-se o docente um modelo de referencia que poderá atuar com vistas a ser exemplo para os estudantes.

A ausência de uma liderança transformacional na identificação e gerenciamento de conflitos, e a não interferência do docente nesses quesitos repercutiu negativamente na avaliação do docente em relação a aspectos de liderança. O fato de uma liderança transformacional não ter atuado frente aos estudantes, ocupando o último lugar em um ranking com escala de 1 a 10, como visto na figura 28 , coloca esse estilo de liderança como provável fonte de motivação 
dos estudantes se porventura adotada, merecendo destaque e novas pesquisas sobre o tema, uma vez que sua ausência gerou desmotivação, observada na figura 25.

Durante o andamento das disciplinas de 2011 foram testadas soluções que ao final foram apontadas como inovadoras por parte dos estudantes, como por exemplo; a utilização do celular do tutor como roteador em uma eventual falta de internet; a utilização do Twitter como forma de gerar informações on-demand sobre os assuntos tratados em aula; a utilização do Skype para um seminário por videoconferência direto do Peru; a participação na aula de um colega pelo viva-voz de um celular; gravação do áudio das aulas para posterior upload para o groupware; transmissão da aula ao vivo para colegas ausentes fisicamente através de um celular, utilizando-se o serviço gratuito de videostream chamado ustream, que permitiu que a aula fosse acompanhada independente da distância e, posteriormente, revisada com imagem e som adequados uma vez que o arquivo permanece disponível 24 hs nos servidores do serviço.

A possibilidade de se criar um banco de dados com as aulas filmadas por um celular com serviço 3G ilimitado agregou valor à disciplina de pós-graduação de 2011, uma vez que permitiu aos estudantes ausentes a interação quanto aos temas debatidos e uma revisão da matéria aos que estavam presentes. Interessante observar que se utilizando apenas um celular, tantas possibilidades de interação emergiram e também salientar que, segundo os estudantes, em nenhum momento da disciplina um celular foi utilizado com o intuito de integração entre os times distanciados fisicamente, cabendo ao mesmo apenas fornecer uma infraestrutura de apoio nas aulas presenciais. A possibilidade de inovar em sala de aula foi oferecida pelo docente, que nesse momento agiu como líder transformacional demonstrando 
flexibilidade, apesar de a iniciativa ter sido do tutor. Como se vê, apenas uma ação como líder transformacional, transformou o andamento da disciplina e otimizou vários processos de aprendizagem. Finalizando a pesquisa foi solicitado que fossem identificados pelos estudantes aspectos positivos, negativos, dificuldades e sugestões a serem implementados em relação ao ambiente virtual de colaboração, sendo os resultados observados na Figura 29.

\begin{tabular}{|c|c|c|c|c|}
\hline Aluno & Aspectos positivos & Aspectos negativos & $\begin{array}{l}\text { Principais dificuldades com as Midias } \\
\text { Sociais }\end{array}$ & Sugestbes \\
\hline 2011_SAD_PÓSG01_Alun01 & $\begin{array}{l}\text { Ambiente muito } \\
\text { completo, com } \\
\text { vários recursos úteis } \\
\text { e interessantes }\end{array}$ & $\begin{array}{l}\text { A natureza experimentaldo } \\
\text { ambiente prejudicou um pouco } \\
\text { as interações }\end{array}$ & $\begin{array}{l}\text { Nảo sabia qual posturaera } \\
\text { considerada como "certa" }\end{array}$ & $\begin{array}{l}\text { Incompatibilidade do } \\
\text { Wiggio com alguns } \\
\text { browsers }\end{array}$ \\
\hline 2011_SAD_P6SG01_Alun02 & $\begin{array}{l}\text { Como passar do } \\
\text { tempo percebemos } \\
\text { no grupo que a } \\
\text { ferramenta foi } \\
\text { melhorada }\end{array}$ & $\begin{array}{l}\text { Dificuldade na utilizaçäo de } \\
\text { documentos compartilhados }\end{array}$ & $\begin{array}{l}\text { Conhecimento técrico sobre a } \\
\text { ferramenta }\end{array}$ & $\begin{array}{l}\text { Possibilitar maior } \\
\text { interaça entre os } \\
\text { usuários }\end{array}$ \\
\hline 2011_SAD_PŚSG01_Alun03 & $\begin{array}{l}\text { Flexibilidade de } \\
\text { tempoe espaço }\end{array}$ & Excesso de intormaçzes & Falta de tempo & $\begin{array}{l}\text { Cobrança na utilização } \\
\text { do amblente virtual. }\end{array}$ \\
\hline 2011_SAD_PÓSG02_Alun01 & $\begin{array}{l}\text { Possibilidade de } \\
\text { interaçio entre os } \\
\text { membros da equipe, } \\
\text { facilidade de acesso }\end{array}$ & $\begin{array}{l}\text { Ausência de um manual de } \\
\text { navegaçăo, axm disso, na } \\
\text { primeira aula fazer com que } \\
\text { cada membro navegue no } \\
\text { amblente }\end{array}$ & $\begin{array}{l}\text { A criaçăo de vários logins e senhas, } \\
\text { assim como a necessidade de acessar } \\
\text { vários desses ambientes diariamente }\end{array}$ & $\begin{array}{l}\text { Utilizar o Moodle como } \\
\text { referéncia em futuros } \\
\text { upgrades }\end{array}$ \\
\hline 2011_SAD_PSSG02_Alun02 & $\begin{array}{l}\text { Eu tive acesso a um } \\
\text { material muito bom, } \\
\text { postado por outro } \\
\text { grupo. Foi bastante } \\
\text { importante, outro } \\
\text { detalhe foramas } \\
\text { contribuicöese } \\
\text { opiniöes de todos os } \\
\text { colegas }\end{array}$ & $\begin{array}{l}\text { Algumas vezeso ambiente } \\
\text { estava lento ou indisponivel, } \\
\text { atrapalhandoo } \\
\text { desenwolvimento das } \\
\text { atividades. Falta uma solução } \\
\text { Wiki }\end{array}$ & $\begin{array}{l}\text { A falta de habilidade para manusear a } \\
\text { ferramentae a pouca experiencia que } \\
\text { tenho sobre atemática que o meu } \\
\text { grupo abordou, fez com que o desafio } \\
\text { fosse maior }\end{array}$ & $\begin{array}{l}\text { O Google poderia } \\
\text { lançar um amblente } \\
\text { totalmente integrado } \\
\text { com o meue-mail, } \\
\text { facilitando o } \\
\text { acompanhamento das } \\
\text { atividades }\end{array}$ \\
\hline 2011_SAD_PósG02_Alun03 & $\begin{array}{l}\text { A possibilidade de } \\
\text { compartilihamento } \\
\text { de informações ea } \\
\text { possibilidade do } \\
\text { registrogeral dos } \\
\text { arquivos estudados }\end{array}$ & $\begin{array}{l}\text { A falta de hablidade em } \\
\text { manusear a ferramentae o } \\
\text { receio de envios errồneos, } \\
\text { talvez me limitaram a interagir }\end{array}$ & $\begin{array}{l}\text { Dificuldade com a interface e as } \\
\text { postagens. Após algum tempoo } \\
\text { problema foiminimizado, entretanto, } \\
\text { twe problemas com a minha internete } \\
\text { descobrique a minha empresa } \\
\text { bloqueava }\end{array}$ & $\begin{array}{l}\text { Desorganizaçāo das } \\
\text { mensagens. Seria } \\
\text { melhorse fosse como } \\
\text { no moodle.Separada } \\
\text { por tópicos }\end{array}$ \\
\hline
\end{tabular}

Figura 29 - Aspectos positivos, negativos, dificuldades e sugestões em relação ao Wiggio observados pelos estudantes de pós-graduação em 2011

Trabalhar em equipe é uma tarefa complexa tanto em ambientes presenciais como nos virtuais. Saber identificar qual o melhor ambiente virtual de colaboração para aplicação da disciplina e o perfil de liderança a ser incorporada pelo docente, tutor ou gestor deste ambiente virtual, passa a ser um fator crítico de sucesso. Outro 
ponto identificado pelos estudantes cabe ao grau de motivação gerado pelo docente na realização das tarefas. Essa motivação, identificada como inspiradora, impacta nos resultados na proporção que os estudantes observam o comprometimento do docente para com os objetivos da ementa da disciplina e a maneira como ela é ministrada. A identidade e o perfil da equipe moldam-se na capacidade do docente em disseminar seus conhecimentos, sem retê-los, estimulando-os intelectualmente. Feedbacks constantes por parte do docente, apontados como um dos fatores mais importantes para a motivação devem ser um recurso a ser utilizado no PBL. O feedback demonstra comprometimento do docente frente aos estudantes e sinaliza que o mesmo está atuante, direcionando os colaboradores para as melhores práticas de aprendizagem. O conhecimento da $\mathrm{Tl}$ e a ética do docente também foram apontados como fatores de impacto, sobressaindo-se aos valores, crenças e atitudes. Reforço positivo, ponderação na escolha do groupware e os seus módulos, permissão para o autogerenciamento e também as cobranças se destacaram como fatores de impacto na realização das tarefas. A empatia, as interferências pessoais no ambiente e a punição por parte do líder foram as características menos destacadas para o comprometimento nos ambientes virtuais utilizados. O perfil de liderança Laissez-faire na condução de uma disciplina de pós-graduação, tendo como suporte um groupware, emergiu como fator crítico de sucesso na engenharia. Identificar as características do líder que podem aprimorar ou comprometer o bom andamento de uma disciplina em um ambiente virtual de colaboração torna-se emergencial. O impacto que essas características representam na condução de uma disciplina refletem nos resultados finais da disciplina e no aprendizado. Sem essas percepções do docente, a universidade pode subutilizar ferramentas de TI e o potencial dos próprios docentes e seus estudantes. Capacitar o docente como líder 
transformacional frente aos estudantes da pós-graduação, tendo o PBL como metodologia, pode gerar vantagem competitiva para a universidade, conforme 0 estudo realizado no Groupware Wiggio.

\section{Análise da utilização das mídias sociais em 2011 por estudantes do $2^{\circ}$ ano, $4^{\circ}$ ano e Pós-graduação com foco no Moodle e Google+}

Ainda em relação aos estudantes de 2011 , dá-se a entender que a falta de motivação repercutiu no andamento das atividades nos Ambientes Virtuais de Colaboração pesquisados, como o Moodle e o Google+. A motivação é uma das dimensões mais importantes de uma liderança transformacional e na maior parte das vezes conduz os indivíduos a superarem as expectativas no cumprimento de metas. Os motivos apontados pelos estudantes foram: Falta conhecimento dos Ambientes Virtuais; Pouco esclarecimento de qual ambiente priorizar; Desorganização dos ambientes virtuais; Falhas de comunicação; Descrença na utilização de mídias sociais "abertas", como o Google+; Perda de foco; Falta de objetividade; Falta de reconhecimento; Não seguimento da ementa da disciplina e ausência de metas claras, como apontado por estudantes do $4^{0}$ ano nos discursos que se seguem,

Achei excelente a utilização do Google+ ao invés de somente o Moodle, mas acredito que faltou um pouco de reconhecimento do nosso trabalho pelo docente (2011_SAD_G01_Alun01).

No começo foi realmente complicado saber qual rede social usar, já que poucos conheciam o Google+. O uso do Moodle como ferramenta obrigatória ou não também não foi esclarecida durante grande parte do tempo (2011_SAD_G01_Alun04). 
Não acredito na utilização de mídias sociais abertas para o desenvolvimento de trabalhos. Acredito apenas nas fechadas. O meu grupo encontrou uma grande dificuldade na comunicação com o docente. A não estipulação de objetivos e metas claras foi a maior dificuldade e desorientou o grupo por várias vezes. Outra dificuldade foi a constante mudança das propostas, não sendo mantidas as decisões tomadas durante o curso. O problema de pesquisa não motivava e não possuía metas claras e objetivas. $O$ docente não orientou a sala e não passou nenhum embasamento teórico (2011_SAD_G07_Alun04).

Faltou maior organização do docente para utilizar o Moodle ou o Google+. As tarefas passadas por ele não eram registradas no Moodle, o que dificultou a própria organização do grupo (2011_SAD_G01_Alun05).

que direciona o pesquisador a observar uma liderança Laissez-Faire por parte do docente no momento em que o discurso do estudante 2011_SAD_G07_Alun02 aponta a um entendimento que não houve uma percepção do mesmo das dificuldades de comunicação enfrentados nos ambientes virtuais e uma falta de atuação individual do mesmo para com os estudantes e grupos,

A multiplicidade dos meios de comunicação fez com que as informações referentes à disciplina ficassem difusas (extremamente negativo, pois quase toda semana recebíamos informações contraditórias sobre o que fazer) (2011_SAD_G07_Alun02).

além da ausência de cobrança na utilização dos ambientes propostos, que relegou o Google+ a um segundo plano por grande parte dos estudantes, como observado pelos estudantes 2011_SI_G05_Alun01 e 2011_SAD_G06_Alun04,

O ambiente virtual poderia ter sido melhor utilizado. Em cada aula deveria ter sido postado o conteúdo ministrado e as atividades propostas deveriam ser especificadas (2011_SI_G05_Alun01). 
O Google+ ficou esquecido na disciplina. Eu, particularmente não gosto de misturar "social" com "trabalho". Quando preciso de algo para o trabalho procuro pesquisar em Redes fechadas e não disponibilizar minhas dúvidas abertamente (2011_SAD_G06_Alun04).

causando uma migração dos estudantes de todas as disciplinas para outros ambientes externos aos ambientes virtuais pesquisados, como mostrado na Figura 30.

\begin{tabular}{|l|l|l|}
\hline \multicolumn{1}{|c|}{$\mathbf{2}^{\circ}$ Ano } & \multicolumn{1}{c|}{$\mathbf{4}^{\circ}$ Ano } & \multicolumn{1}{c|}{ Pós-Graduação } \\
\hline Facebook: & Facebook: & Skype: \\
43 de $56=76,78 \%$ & 14 de $37=37,83 \%$ & 7 de $11=63,63 \%$ \\
MSN: & Skype: & MSN: \\
26 de $56=46,42 \%$ & 9 de $37=24,32 \%$ & 6 de $11=54,54 \%$ \\
Skype: & Twitter: & Facebook: \\
7 de $56=12,5 \%$ & 5 de $37=13,51 \%$ & 2 de $11=18,18 \%$ \\
Dropbox: & MSN: & Yahoo mail: \\
3 de $56=5,35 \%$ & 5 de $37=13,51 \%$ & 1 de $11=9,00 \%$ \\
Celular: & Hotmail: & \\
3 de $56=3,57 \%$ & 1 de $37=2,70 \%$ & \\
& Celular: & \\
& 1 de $37=2,70 \%$ & \\
\hline
\end{tabular}

Figura 30 - Outras Mídias Sociais e ferramentas sociais utilizadas durante o semestre de 2011 fora do Google+e do Moodle

Quando questionados se haviam utilizado o Google+ em suas atividades a grande maioria dos estudantes de todas as disciplinas optaram pelas alternativas Discordo Plenamente ou Discordo para a afirmação Me aderi ao Google+ e utilizei constantemente o serviço para realizar minhas tarefas em grupo (Figura 31), o que demonstra que não houve cobrança por parte do docente, uma característica Laissez-Faire de liderança. 


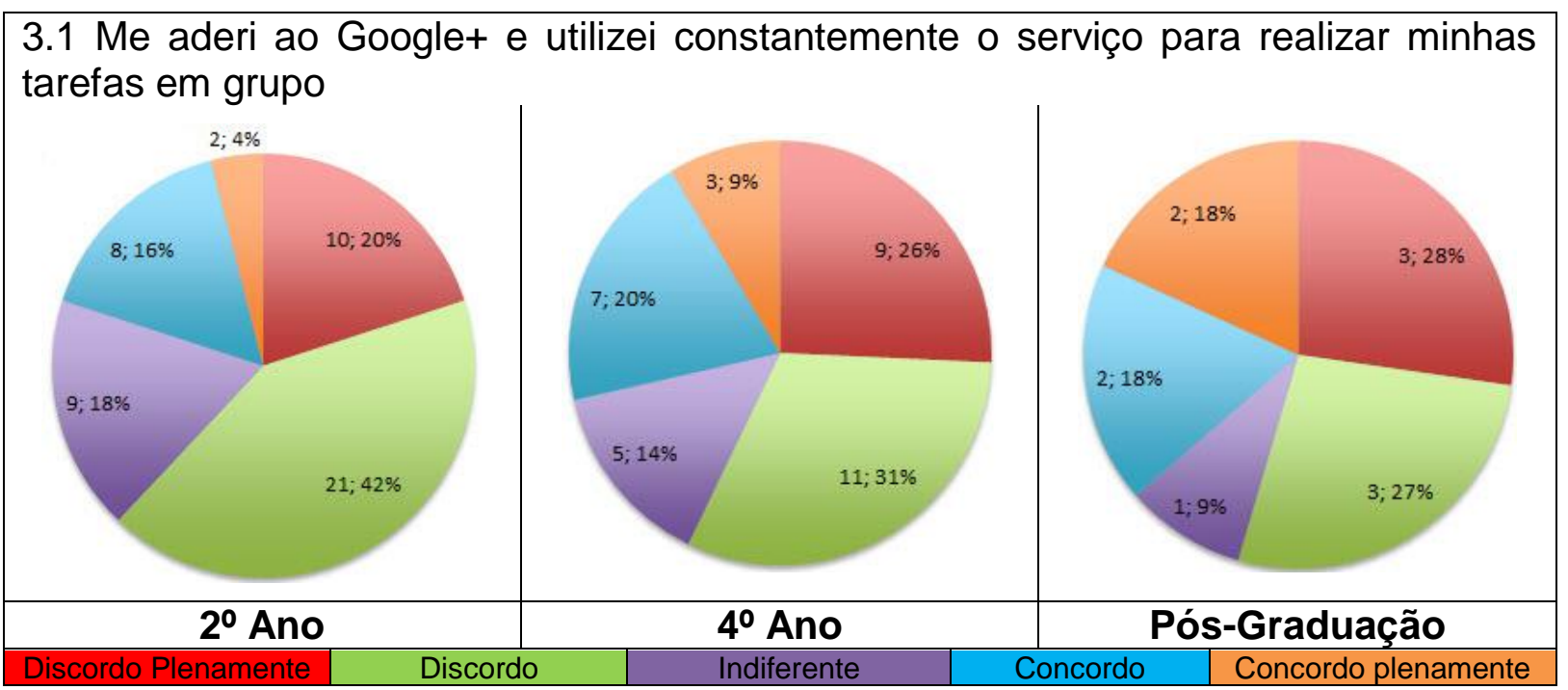

Figura 31 - Análise da utilização do Google+ no Ano de 2011

Importante frisar que do total de recursos do Google+ utilizados pelos estudantes da engenharia de produção da EESC-USP (Apêndice 6), os grupos melhores avaliados no final do semestre foram os que utilizaram esse ambiente com uma constância superior aos grupos com as piores avaliações (Apêndices 7 e 8 respectivamente), sem que este fato tenha repercutido na avaliação do docente, o que demonstra que a nota final dos estudantes inseridos nesses grupos foi diretamente proporcional ao grau de comprometimento para com as orientações iniciais do docente na utilização das mídias sociais presentes neste ambiente, mesmo sem a cobrança do mesmo no decorrer do semestre. Esse fato caracteriza pró-atividade das equipes melhores avaliadas e sinalização de uma necessidade de atuação individual, estimulo intelectual e motivação para com as equipes sem este perfil pró-ativo, dimensões de uma liderança transformacional não observada no docente nos contextos estudados, que pode ter acarretado em perda de oportunidades de aprendizagem para estes estudantes. O discurso do estudante 2011_SAD_G01_Alun05 e 2011_SAD_PósG01_Alun04 demonstra falta de foco nos conteúdos disponibilizados nos ambientes virtuais, com ênfase no Google+, 
A única ressalva que faria seria quanto ao uso do Google+. Prefiro um ambiente específico para estudo, como o Moodle. Uma rede social oferece muitas oportunidades pra geração de 'ruídos' que não dizem respeito à oferta da disciplina. Também não percebi que as postagens do Google+ estavam fortemente correlacionadas aos conteúdos abordados na disciplina, sendo utilizada como uma rede social convencional. Senti falta de um direcionamento mais objetivo e, por isso, participei de modo superficial do Google+ (2011_SAD_G01_Alun05).

... sugiro uma aula inicial de instrução para a utilização do Google+, assim poderíamos fazer melhor proveito dos serviços oferecidos na ferramenta (2011_SAD_PósG01_Alun04).

gerando desmotivação.

Quando confrontados com a afirmativa $O$ Moodle me proporciona mais motivação para trabalhar em equipe do que o Google+ (Figura 32), a maioria dos estudantes do $2^{\circ}$ ano e da pós-graduação optaram por Concordo plenamente e Concordo e a ampla maioria dos estudantes do $4^{\circ}$ ano optaram entre Discordo plenamente e Discordo, resultado que pode ser entendido quando analisamos a Figura 34, que afere o nível de facilidade em se trabalhar no Google+ pela afirmativa não explorei a fundo as possibilidades do Google+ porque achei o Site complicado, onde $60 \%$ dos estudantes do $4^{\circ}$ ano optaram por Discordo plenamente e Discordo, porcentagem maior que a dos estudantes do $2^{\circ}$ ano e da pós-graduação, que demonstraram maior dificuldade. O número de estudantes que optaram pela alternativa indiferente pode demonstrar facilidade dos mesmos na adaptabilidade em ambos os ambientes virtuais. 


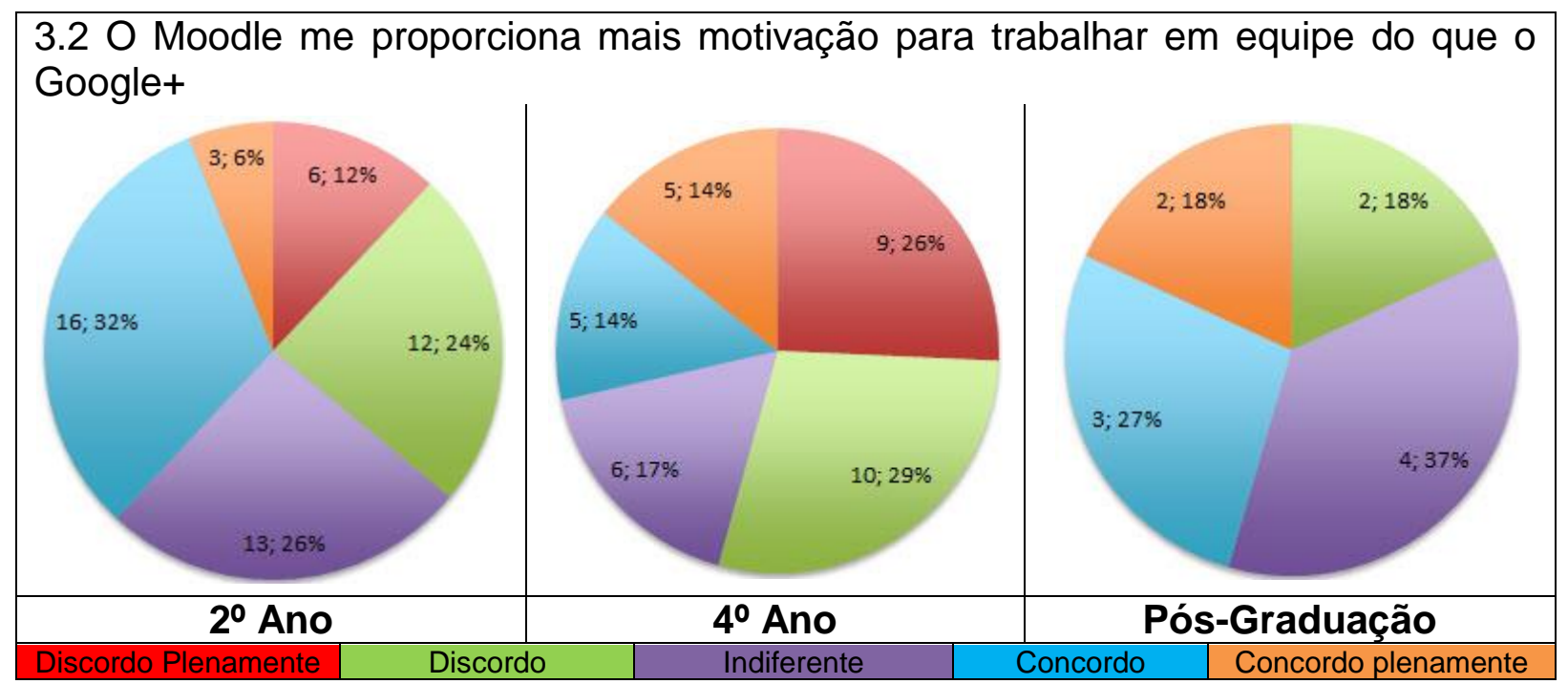

Figura 32 - Comparação da motivação gerada utilizando-se o Moodle quando confrontado ao Google+ no trabalho em equipe no ano de 2011

Uma visão sistêmica do nível de entendimento dos estudantes em relação aos ambientes virtuais torna-se necessário, uma vez que diferentes classes podem ter diferentes visões do contexto de aula, gerando diferentes níveis de motivação. Essa é uma característica da liderança transformacional, que por meio de uma visão holística da classe, pode atuar nas partes (grupos) gerando maior nível de motivação pelo suporte aos estudantes.

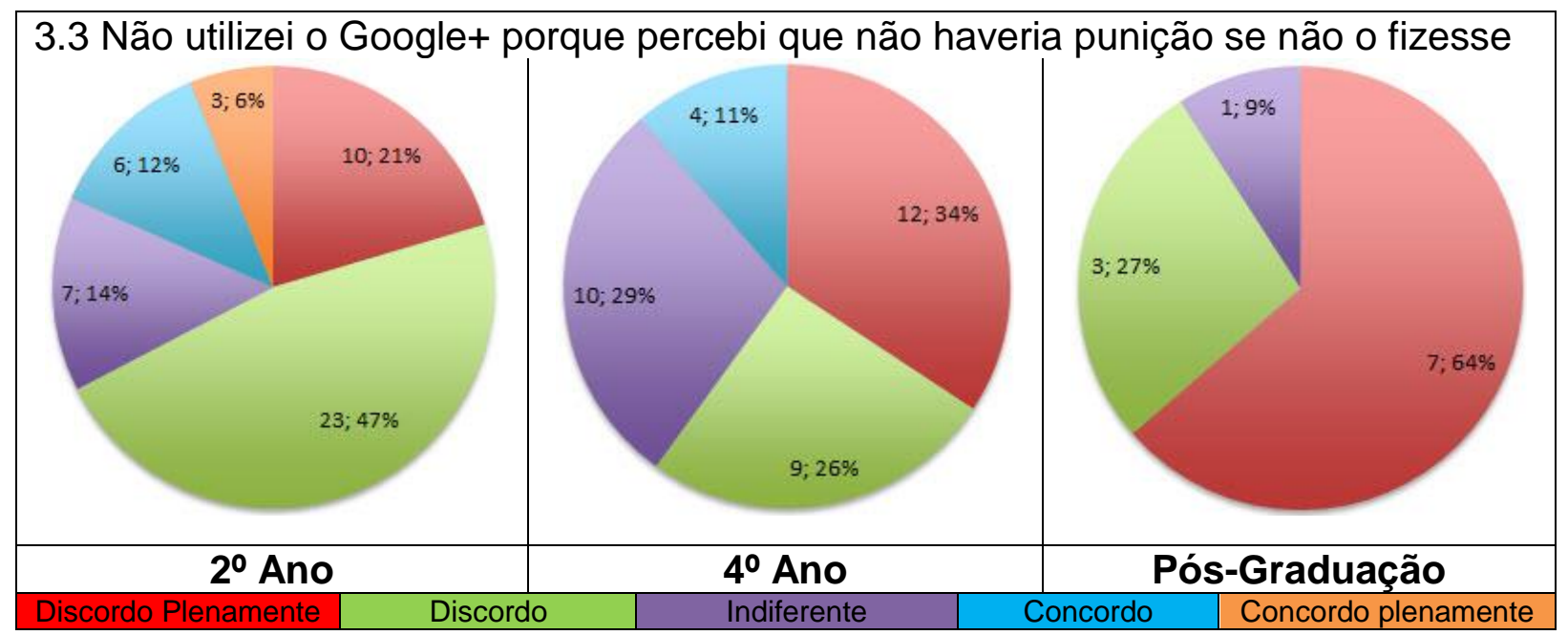

Figura 33 - Análise da utilização do Google+ e a percepção do estudante em relação a um perfil punitivo do docente no ano 2011 
A Figura 33 evidencia que a não utilização do Google+ pela maioria dos estudantes não foi em detrimento da percepção que não haveria punição, mas sim pela dificuldade em aceitar a mudança do paradigma vigente, que coloca o Facebook no patamar mais elevado em termos de interações virtuais, demonstrado pela maior motivação gerada nos estudantes da graduação quando interagindo-se pelo Facebook (figura 34), contrastando-se aos estudantes de pós-graduação pelo grau de maturidade dos mesmos em aceitarem novos desafios. Como havia acabado de ser lançado e possuindo um maior nível de complexidade, o Google+ reverteu em desmotivação aos estudantes, que viam no "novo" uma ameaça, e na falta de cobrança do docente, uma oportunidade para migrarem para outras mídias sociais, o que de certo modo foi negativo aos estudantes, que deixaram de vivenciar no Google+ uma realidade que mais se aproxima dos Groupwares que nos dias atuais já aparecem nas organizações empresarias.

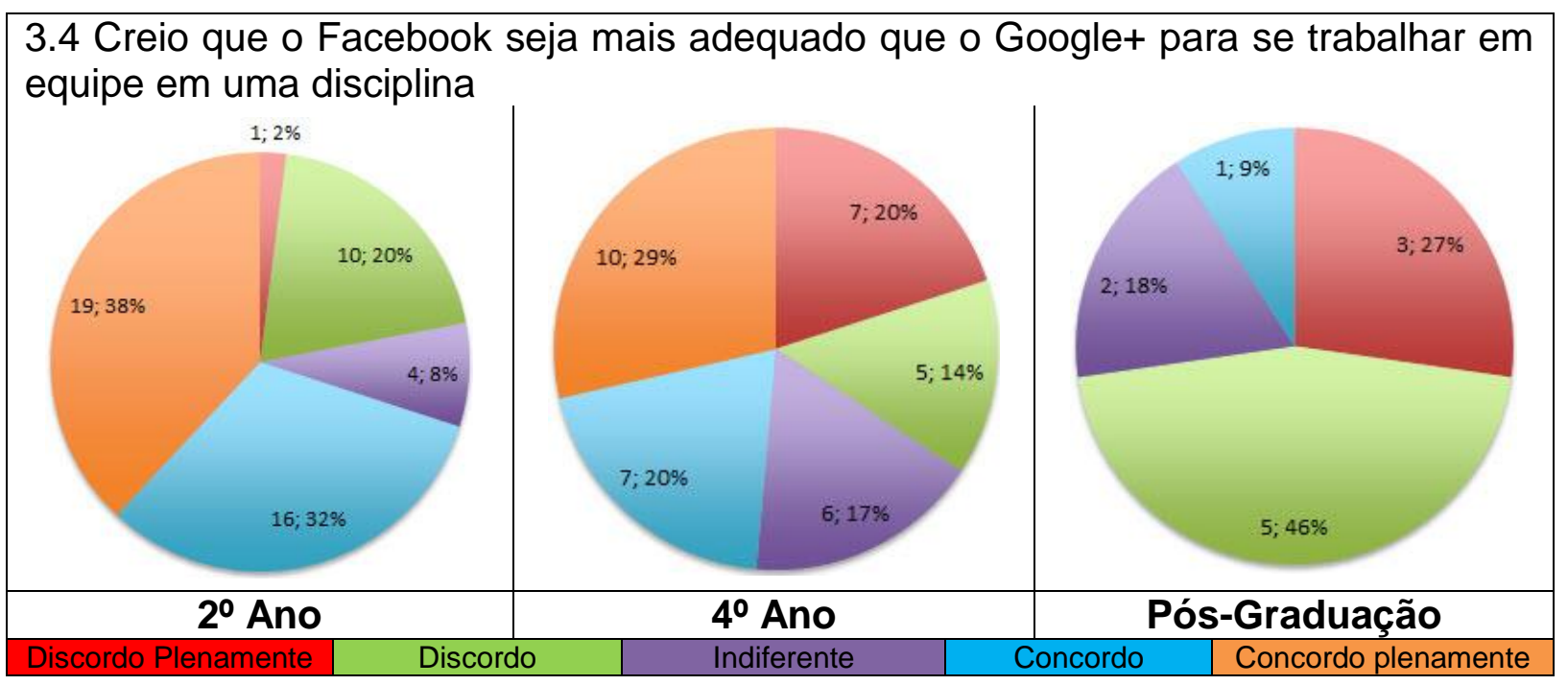

Figura 34 - Comparação entre o índice de motivação gerado entre o Facebook e o Google+ no trabalho em equipe no ano de 2011

Atuando com o perfil de liderança transacional por meio de cobranças e recompensas, o docente poderia ter conduzido os estudantes a um novo patamar, 
mesmo que em um momento inicial houvesse a rejeição, que poderia ter sido combatida com a incorporação contextual do perfil de liderança transformacional, dimensão esta que emerge em contextos vistos como complicados, como o Google+, na visão dos estudantes do $2^{\circ}$ ano e pós-graduação (Figura 34).

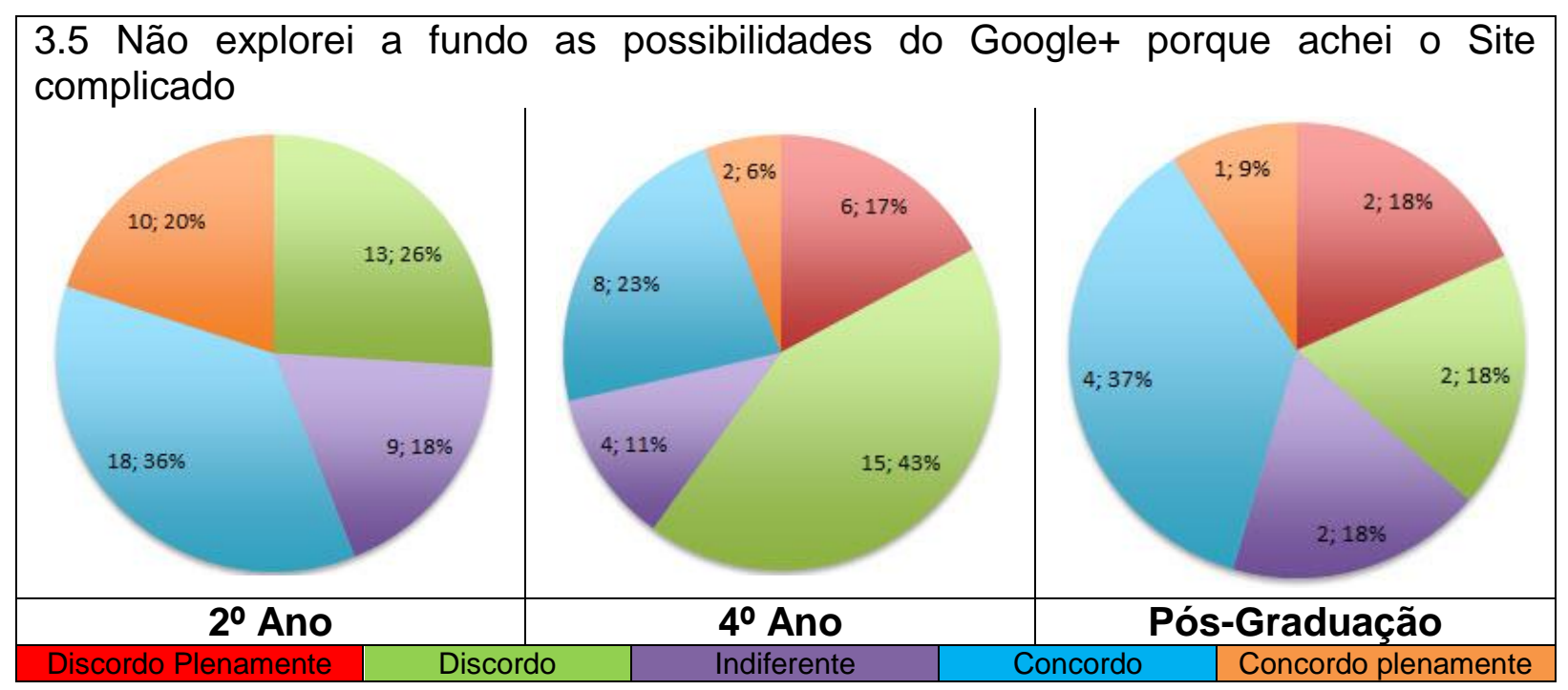

Figura 35 - Análise do índice de complexidade do Google+ para o trabalho em equipe no ano de 2011

Observar que um problema está se instalando e agir antes que o mesmo se consolide é uma dimensão de liderança transacional por exceção-ativa, que não foi observada no docente, induzindo novamente ao perfil Laissez-faire. Maior organização no Moodle foi apontada nas sugestões ao Docente como emergencial, o que evidencia que não houve a percepção do problema, como podemos observar nos seguintes discursos:

Maior organização no Moodle para maior clareza e planejamento dos estudantes (2011_SI_G01_Alun04).

Maior organização no Moodle para os estudantes terem clareza a respeito do que devem fazer (2011_SI_G01_Alun05). 
Maior organização no Moodle e na disciplina pois ninguém sabia o que era para ser feito (2011_SI_G01_Alun03).

O Moodle, uma ferramenta muito importante se bem utilizada, ficou desatualizado durante todo o curso (2011_SAD_G02_Alun01).

Não utilizamos o Moodle para a formação de uma base de arquivos (dados). Senti falta apenas desse item (2011_SAD_PósG02_Alun03).

Dificuldades dos estudantes em saberem o que deveria ser feito demonstra falta de alinhamento do método, da ementa da disciplina e do docente para com os estudantes. O estudante 2011_SI_G02_Alun02 aponta, inclusive, que recompensas e punições não foram apregoadas pelo docente no controle da sala. A Wiki do Moodle mostrou-se muito válida no trabalho em equipe em um ambiente adverso, uma vez que proporciona maior controle do conteúdo gerado pelo grupo, o que não eliminou a desmotivação no contexto estudado. Muitos desses problemas são descritos no discurso dos seguintes estudantes:

Acredito que um acompanhamento mais eficiente por parte do docente resultaria em uma melhor organização e fluidez da disciplina. Quando as atividades não são determinadas claramente, nem os critérios de avaliação, a equipe não se sente confortável e nem confiante se está fazendo um trabalho de qualidade. Creio que o docente deveria ter usado mais o Moodle para divulgação dos afazeres, recompensas, punições, etc. (2011_SI_G02_Alun02).

Durante a disciplina tivemos dificuldades em saber o que deveríamos fazer para a aula seguinte, o que deveríamos pesquisar e se tínhamos que montar uma apresentação ou não. Por duas vezes montamos um Slide-show e esquematizamos uma apresentação, mas não tivemos a oportunidade de fazê-lo. O Moodle poderia ter sido melhor utilizado com instruções do que deveríamos fazer a cada semana, além de um cronograma fixo, possivelmente com a data de cada apresentação. Um ponto positivo da disciplina foi a realização dos trabalhos principais através das Wikis, que 
possibilitou uma melhor organização do que estava sendo e o que já havia sido feito (2011_SI_G02_Alun04).

O estudante 2011_SI_G07_Alun05 apontou que o Moodle poderia ter sido utilizado para a divulgação das notas logo em seguida às atividades para poderem mensurar se estavam caminhando corretamente, pois a lacuna dessa percepção parece ter sido um dos grandes problemas enfrentando pela classe.

No aspecto do Moodle, poderiam ser colocadas as notas de acordo com o andamento do curso, para que os estudantes pudessem acompanhar seu rendimento (2011_SI_G07_Alun05).

Podemos observar que o fator liderança emerge novamente como norteador também em um ambiente virtual de aprendizagem consolidado, como o Moodle. Uma liderança transformacional é mais facilmente observável em condições adversas, onde membros de um time se encontram desorientados e buscam um alicerce nos traços de personalidade que melhor se adequar a determinados contextos, papel que o docente deve desempenhar.

O treinamento nas ferramentas também mostrou-se preponderante. Não se pode apostar em conhecimento prévio do estudante. Existem vários níveis de conhecimento e curvas de aprendizagem e a realidade de cada pessoa se difere de outra mesmo em mesmos contextos, por mais simples que possam parecer. Mesmo havendo uma palestra com exemplos práticos proferida pelo monitor da disciplina de como era o funcionamento do Google+ na tentativa de criar um conhecimento básico para posterior consolidação, não foi o suficiente, conforme o discurso do estudante 2011_SAD_PósG01_Alun04 da pós-graduação. 
Gostei muito da disciplina e espero participar de outras. Sugiro uma aula inicial de instrução para a utilização do Google+, assim poderíamos fazer melhor proveito dos serviços oferecidos na ferramenta (2011_SAD_PósG01_Alun04).

Relevante observar que 36\% dos estudantes da pós-graduação não acharam o Google+ complicado, confrontando os $46 \%$ que acharam, o que deixa nítido que mesmo em uma classe de pós-graduação de uma disciplina de tecnologia da informação, o ambiente virtual de aprendizagem deve ser inserido com cautela, pois presentes na sala estarão estudantes com vivências e visões de mundo diferentes.

A complexidade vivenciada nos ambientes virtuais uma vez mais é evidenciada pela Figura 36. A análise do índice de motivação ao se trabalhar com o Moodle no ano de 2011 demonstra variações de acordo com as disciplinas. Estudantes do $2^{\circ}$ ano, assim como os estudantes da pós-graduação na grande maioria apontam facilidade em se trabalhar no Moodle, o que não ocorre com os estudantes do $4^{\circ}$ ano.

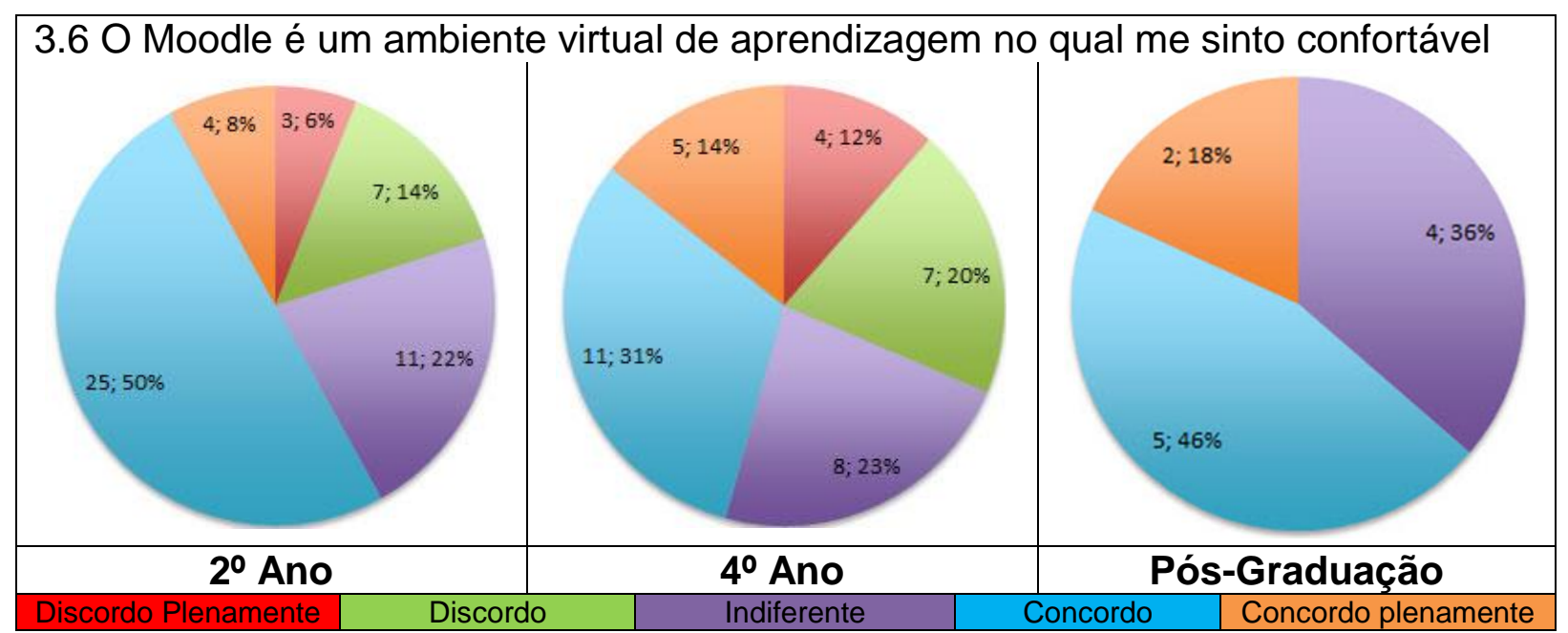

Figura 36 - Análise do índice de motivação ao se trabalhar com o Moodle no ano de 2011

Esse contexto sugere que o docente, por meio de uma visão holística das salas, e de qual modo os estudantes estão se comportando, possa interferir pontualmente nos problemas que surjam, identificando-os e combatendo-os, para que oportunidades de aprendizagem não sejam perdidas, como muito ocorreu de 
acordo com os discursos dos estudantes do $2^{\circ}$ ano abaixo, que mesmo apontando facilidade em se interagir com o ambiente, não obtiveram a motivação necessária pelo fato de alguns gargalos não terem sido observados a tempo pelo docente, como uma maior clareza dos objetivos das aulas nos ambientes híbridos a serem inseridos no Moodle.

Maior organização do Moodle, por datas das aulas, e tarefas para cada data (2011_SI_G01_Alun02).

Maior organização no Moodle para ter clareza e planejamento dos estudantes (2011_SI_G01_Alun04).

Maior organização no Moodle para os estudantes terem clareza a respeito do que devem fazer (2011_SI_G01_Alun05).

Maior organização no Moodle e na disciplina pois ninguém sabia o que era para ser feito (2011_SI_G01_Alun03).

O Moodle, uma ferramenta muito importante se bem utilizada, ficou desatualizado durante todo o curso (2011_SAD_G02_Alun01).

Não utilizamos o Moodle para a formação de uma base de arquivos (dados). Senti falta apenas desse item (2011_SAD_PósG02_Alun03).

No aspecto do Moodle, poderiam ser colocadas as notas de acordo com o andamento do curso, para que os estudantes pudessem acompanhar seu rendimento (2011_SI_G07_Alun05).

Acredito também que poderia haver um maior uso do Moodle (2011_SAD_G02_Alun02).

Organizar o Moodle por datas das aulas e tarefas para cada data (2011_SI_G01_Alun02). 
Muito interessante observar a atuação do PBL nos ambientes virtuais no discurso do estudante 2011_SI_G03_Alun02, mesmo porque o PBL prega a construção pelo próprio estudante do seu conhecimento, o que de certa forma ocorreu, talvez não com o nível de qualidade que poderia ter alcançado pelas lacunas de liderança que o estilo Laissez-faire deixa ao docente.

\footnotetext{
Ter uma maior especificação do trabalho no Moodle. Achava interessante ter data fixa e o que era realmente para se fazer no trabalho. Esse é o grande problema, pois nem o líder do grupo era capaz de dizer corretamente o que fazer. Em um momento ele (docente) fez certos membros pesquisar coisas a mais (2011_SI_G03_Alun02).
}

\section{Análise da utilização das mídias sociais em 2012 por estudantes do $2^{\circ}$ ano, $4^{\circ}$ ano e Pós-graduação com ênfase no Moodle e Facebook.}

Nas dinâmicas ocorridas nos ambientes virtuais em 2012 na comunicação entre o docente, o pesquisador e os estudantes, priorizou-se a utilização do Facebook e do Moodle. Sugestionou-se aos estudantes pelo docente a utilização também do microblog restrito a 140 caracteres conhecido como Twitter, neste caso, para os estudantes poderem acessar informações pertinentes aos tratados pelo docente no momento em que elas ocorrem, sem intermediários, ou seja, as notícias sendo geradas e postadas pelos formadores de opinião, como estudantes, docentes, organizações e empresas de diversas áreas e locais ao redor do mundo, ainda com a possibilidade de interação entre os estudantes por meio de mensagens, que podem ser diretas e privadas, ou publicas, com fotos e links podendo ser anexados. No momento em que um assunto era tratado em sala de aula os estudantes podiam percorrer o Twitter e verificar o que estava sendo discutido sobre aquele mesmo assunto por outros estudantes ou organizações. A utilização do Twitter não teve 
adesão pela dificuldade da quebra do paradigma tradicional de ensino, voltado aos conteúdos pré-formatados, e também pela atitude Laissez-faire do docente, de não cobrança sistemática, o que vai ao encontro de certo modo ao PBL, que prega ao estudante ser o gestor do próprio aprendizado. De um universo de 197 estudantes pesquisados entre 2011 e 2012, apenas 3 estudantes do $2^{\circ}$ ano do ano letivo de 2012 utilizaram o Twitter com certa frequência para se comunicarem, e apenas nas primeiras semanas, o que é alarmante uma vez que essa mídia social é uma das mais eficientes formas de busca de informações da atualidade pelo fato de, como já mencionado, ter como autor das postagens muitas vezes os próprios autores dos livros que os estudantes estejam a utilizar como referencial, o que fornece condições de novas abordagens, de temas já consolidados, estarem sendo discutidos no momento em que ocorrem, e não após a publicação por editoras ou na WEB.

Em certa aula o pesquisador enviou uma mensagem a um autor de um livro, que tinha o perfil confirmado como verdadeiro pelo Twitter, dizendo que estávamos discutindo naquele exato momento assuntos tratados por ele em determinado capitulo do livro e o mesmo respondeu agradecendo o interesse apenas 5 (cinco) minutos após o envio. Tantas possibilidades de interações e acesso a informação foram negligenciados pelos estudantes, o que poderia ter sido combatido com o líder da disciplina cobrando os estudantes de forma mais enfática, agindo com um perfil de líder transacional. Essa é uma observação muito importante na fase de implantação do PBL em uma IES. Nos contextos estudados, fica evidente que o método deve ser inserido de forma gradual e com acompanhamento dos estudantes de perto pelo docente, o que uma atitude Laissez-faire não apoia.

$\mathrm{Na}$ análise da utilização do Facebook (Figura 37), grande parte dos estudantes não utilizaram de forma proativa as possibilidades de interação nos 
grupos de estudo formados, mesmo sendo o Facebook a rede social onde quase a totalidade dos 197 estudantes que participaram da pesquisa terem acesso, com menor porcentagem dos estudantes da pós-graduação. A inserção do PBL como método de ensino na engenharia em ambientes híbridos passa a ser um desafio complexo e, ao mesmo tempo, repleto de ferramentas que podem apoiá-lo, como as mídias sociais e perfis de liderança adequados a cada contexto.

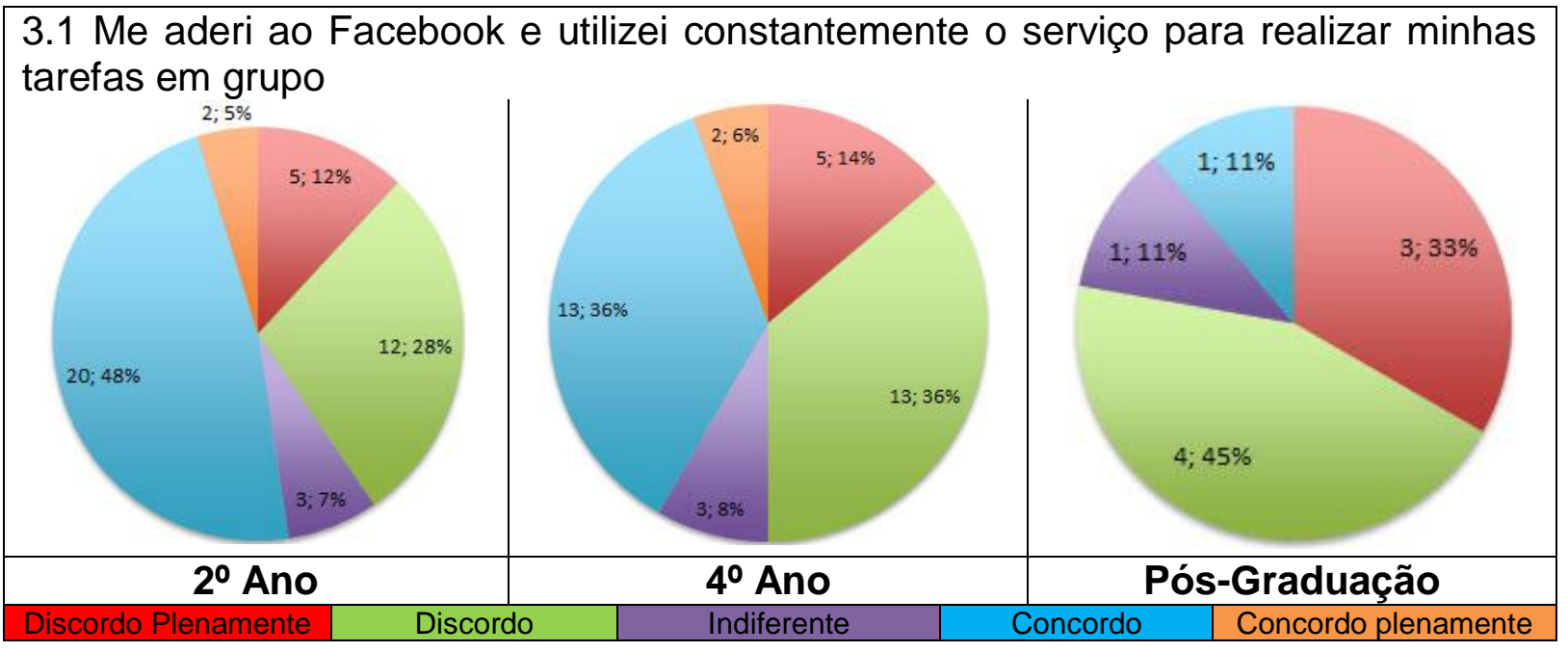

Figura 37 - Análise da utilização do Facebook no Ano de 2012

Pelas observações do pesquisador, grande parte da ausência dos estudantes nas discussões pelo Facebook se deu pela pouca participação do docente no ambiente, provendo pouca motivação para que os estudantes sentissem que estavam sendo valorizados, ficando grande parte deste atributo da motivação para os monitores, que de certa forma se responsabilizam integralmente pelo ambiente, quando seria tarefa do docente. A obrigatoriedade da participação dos estudantes no Facebook para que houvesse uma nota específica e formas de avaliação pouco claras de como essa participação deveria ocorrer mostraram-se desestimulantes para os estudantes, gerando desmotivação no decorrer das disciplinas. O acúmulo 
de informações e o desvio dos temas para assuntos pouco pertinentes também foram apontados como desestimulantes.

O Facebook não agregou valor ao aprendizado dos estudantes da forma como era esperado, muito disso pela liderança Laissez-faire do docente, que acreditou que os estudantes da engenharia estariam preparados para o autogerenciamento, gerenciamento que acabou sendo feito pelos monitores, que muitas vezes também não estavam em sintonia com os objetivos propostos pelo docente, tomando o gerenciamento do ambiente para si próprios, causando confusão. Os discursos dos estudantes abaixo demonstra um pouco da insatisfação gerada pela falta de uma liderança mais presente por parte do docente.

Acredito que o uso de mídias sociais como Facebook para um grupo tão grande como foi introduzido permitiu um acumulo muito grande de informações, mas esse excesso de informações levou que grande parte dos estudantes não participassem de forma efetiva e que agregasse valor nas discussões ao grupo (2012_SAD_G01_Alun02).

O Facebook foi uma ferramenta desmotivadora e desviou-se do foco da disciplina (ninguém achou o trabalho lá satisfatório ou interessante) (2012_SI_G05_Alun05).

Creio que as tarefas que deveriam ser realizadas deveriam ser avisadas de uma forma diferente, além do Facebook (2012_SI_G07_Alun01).

Creio que os estudantes da USP não estejam preparados para este método. Facebook é uma ferramenta para lazer e não pode ser usada como critério de avaliação (2012_SI_G06_Alun03).

Tirar um pouco a importância da participação no Facebook e priorizar a participação em sala de aula e a elaboração do projeto, pois, no Facebook acabam postando reportagens que não contribuem significativamente no aprendizado, só para obterem nota de participação (2012_SI_G04_Alun05). 
Tornar a discussão do Facebook espontânea e não dependente de nota, o que torna a discussão forçada (2012_SI_G06_Alun01).

Houve excesso de informação no Facebook, o que dificultava uma leitura crítica e sistemática (2012_SI_G01_Alun03).

O Facebook ficou sobrecarregado de informações, o que atrapalha na hora de postar e demonstrar opinião sobre o tópico (2012_SAD_G01_Alun01).

O fato de postar no Facebook por obrigação é um absurdo (2012_SAD_G06_Alun02).

Excessiva importância dada ao Facebook (2012_SI_G04_Alun01).

A importância dada ao Facebook não faz sentido (2012_SI_G02_Alun04).

A importância dada ao Facebook é excessiva, irreal. O que foi feito por meio deste meio foi, na maioria das vezes, totalmente fora do contexto e do conteúdo do curso, visto que a maioria dos posts não tinha relação com a matéria (2012_SI_G04_Alun06).

Creio que o Facebook não pode ser utilizado como ferramenta de ensino. Acho também que os estudantes da USP não estão preparados para esse método de ensino, que seria muito melhor se fosse substituído por aulas práticas (cases) e mais trabalhos (2012_SAD_G06_Alun02).

Priorizar atividades e participação em sala de aula e não no Facebook, destacando a qualidade e não a quantidade! (2012_SI_G04_Alun03).

Quando confrontado com o Facebook, o Moodle mostrou-se mais apto ao trabalho em equipe, mas não menos desestimulante, com $40 \%$ dos estudantes do $2^{\circ}$ ano, $48 \%$ dos estudantes do $4^{\circ}$ ano e $56 \%$ dos estudantes da pós-graduação terem apontado maior motivação para se trabalhar em equipe neste ambiente do que no Facebook (ver Figura 38). 
Saber utilizar corretamente as mídias sociais e com elas otimizar os processos inerentes à disseminação de conhecimentos pode motivar os alunos a encararem os desafios quaisquer que sejam os ambientes virtuais utilizados.

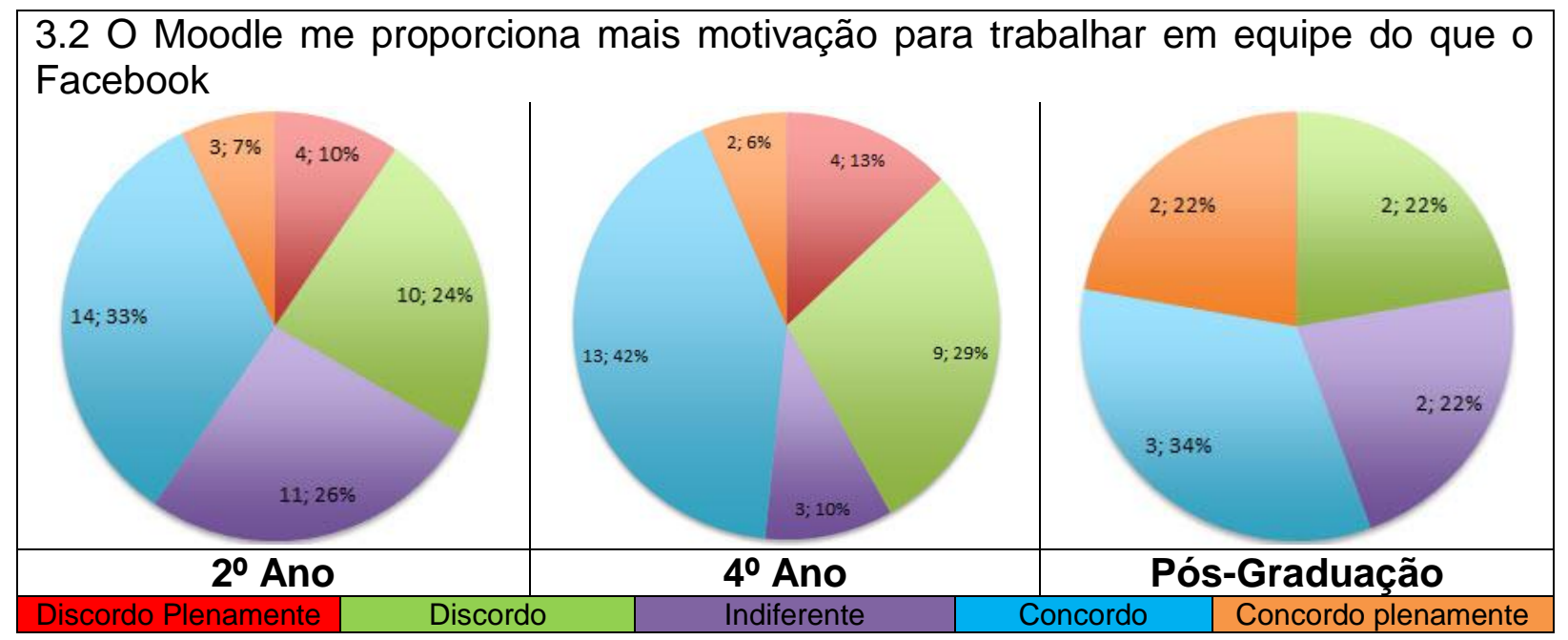

Figura 38 - Comparação da motivação gerada utilizando-se o Moodle quando confrontado ao Facebook no trabalho em equipe no ano de 2012

Falta de organização, datas e tarefas desconexas e ausência de padronização das tarefas foram apontadas nas sugestões ao docente como emergenciais ao se trabalhar no Moodle, o que evidencia que não houve a percepção do problema pelo docente, acentuando-se o perfil Laissez-faire do docente analisados em outros itens. Esse fato implica, ainda, que o docente não atuou como um e-líder transformacional ao não ter observado a tempo a desmotivação, como podemos observar nos seguintes nos discursos abaixo.

Houve pouco uso do Facebook, ou acompanhamento (inclusive eu); Cadastrar e-mail e telefone dos estudantes no Moodle, onde há uma maior integração, contato e acompanhamento (2012_SAD_Pós_G02_Alun04). 
Minha sugestão é a elaboração de um sistema que integre Moodle, Facebook e, possivelmente, um sistema de fóruns (independente do Moodle) (2012_SI_G08_Alun01).

O Moodle não é um ambiente que favorece os trabalhos da disciplina (2012_SAD_G01_Alun06) .

Utilizar mais o Moodle para troca de materiais; divulgação de "tarefas" para a aula seguinte; fóruns para discussão sobre trabalhos em equipe (2012_SAD_Pós_G02_Alun03).

O Moodle não é um ambiente que favorece os trabalhos da disciplina. A impressão que fica é que os estudantes ficaram desmotivados durante toda a disciplina (2012_SAD_G01_Alun06).

Organização e aviso prévio dos acontecimentos do Moodle (2012_SI_G07_Alun04).

O Moodle é muito bagunçado com relação as atividades: os prazos não são padronizados; os títulos com datas todas erradas, gerando uma grande confusão e estresse (2012_SI_G05_Alun05).

Entende-se que a não utilização dos ambientes virtuais da forma que se esperava para que um aprendizado mais consolidado fosse alcançado por parte dos estudantes foi mais em detrimento da desmotivação do que de cobranças e punições, conforme analisado pelas figura 33 e 39. 


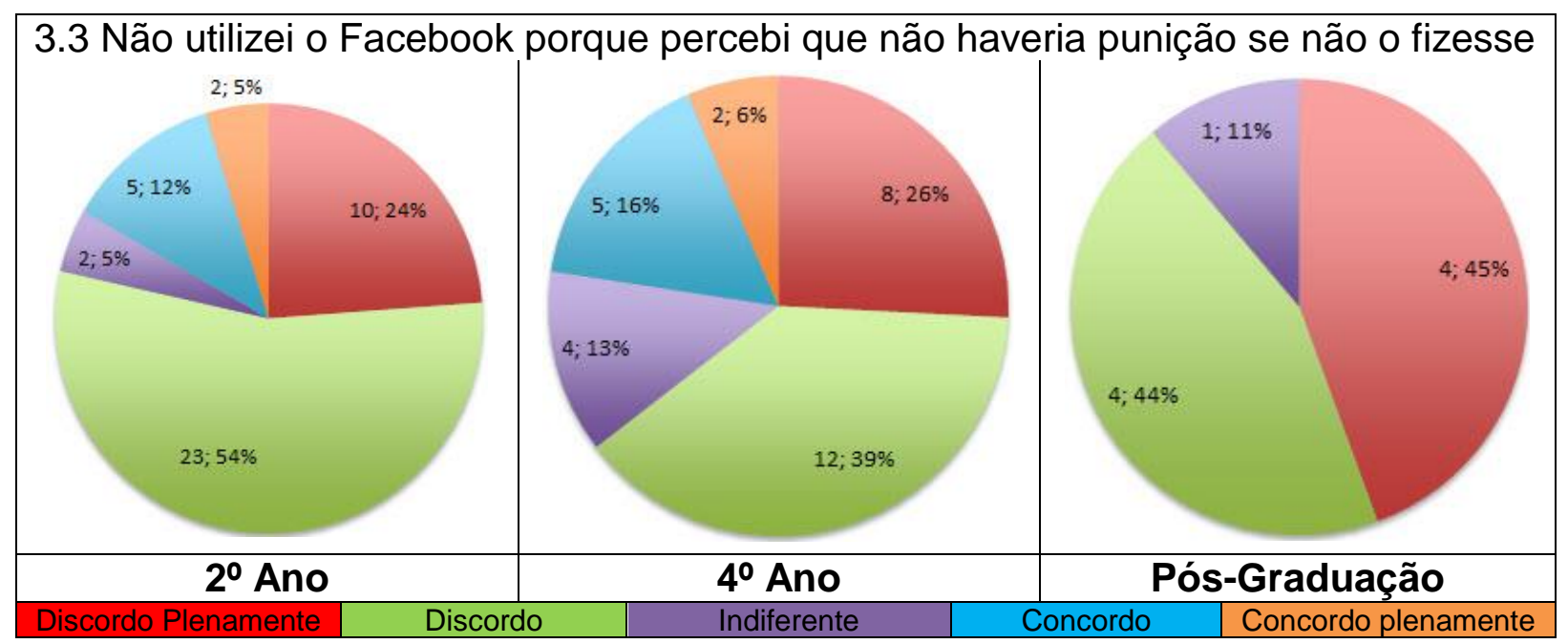

Figura 39 - Análise da utilização do Facebook e a percepção do estudante em relação a um perfil punitivo do docente no ano 2012

Tal observação releva a um patamar superior a necessidade de uma liderança transformacional, que estimule os estudantes a aprenderem também nos ambientes virtuais, e não a adoção de uma atitude punitiva por parte do docente, ainda muito em voga atualmente, não excluindo a necessidade da punição de acordo com o contexto, mas que esta não seja a regra.

Quando comparados o Facebook e o Google+ (Figura 40), fica claro que a complexidade do sistema é fator crítico de sucesso quando novamente a complexidade do Google+ afastou os estudantes que nele já estavam inscritos, assim como ocorreu em 2011. Mesmo o Google+ apresentando em 2012 melhoras significativas em relação ao ano de lançamento (2011), e fornecendo todas as ferramentas para um trabalho em equipe otimizado, como um clássico Groupware pode apresentar, não cativou mais os estudantes do que a simplicidade limitada do Facebook. 


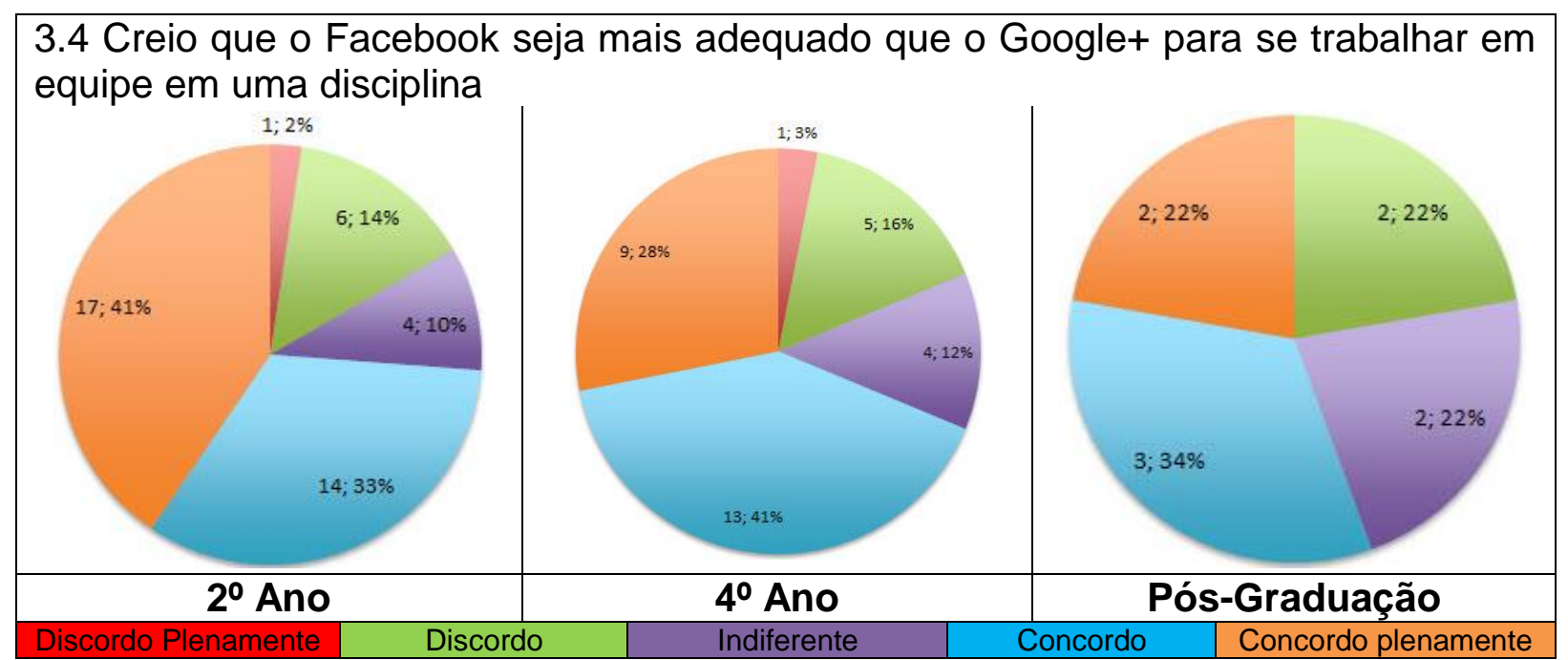

Figura 40 - Comparação entre o índice de motivação gerado entre o Facebook e o Google+ no trabalho em equipe no ano de 2012

Continuando, a realidade dos novos tempos impõe de certa forma que os docentes universitários conduzam os estudantes além de suas zonas de conforto, para que esses vivenciem a realidade que as organizações os apresentarão, e já apresentam, por intermédio da TIC em seus ambientes virtuais proprietários, que se alastram em todos os setores, permitindo a realização de tarefas e projetos à distancia. De certa forma a liderança Laissez-faire, sem os traços motivacionais necessários, impede que, por meio do estímulo intelectual e atuação individual, o docente transponha o status quo do estudante, fazendo que o mesmo atue na complexidade necessária para o entendimento e superação das dificuldades dos ambientes virtuais mais difíceis de entenderem, corroborando a Figura 41, que demonstra a dificuldade dos estudantes em se trabalhar em um ambiente complexo como o Google+. 


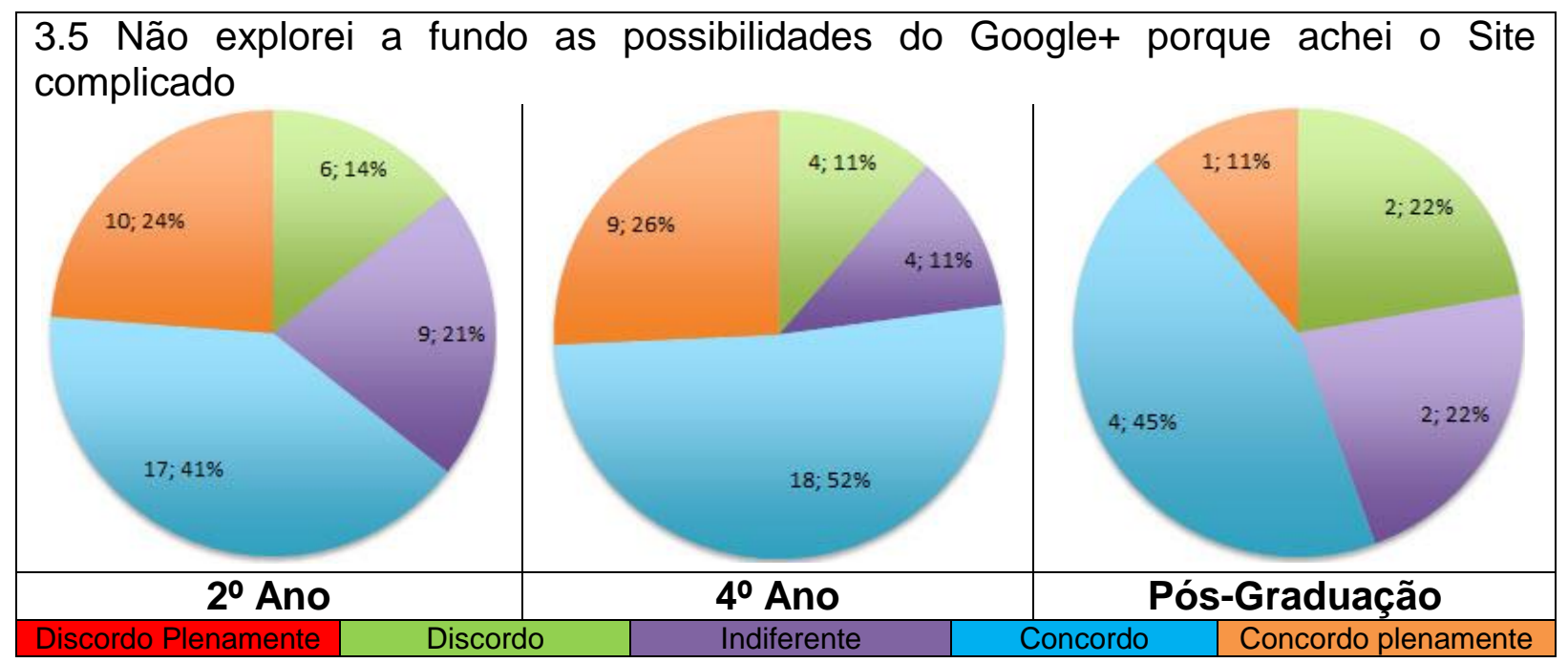

Figura 41 - Análise do índice de complexidade do Google+ para o trabalho em equipe no ano de 2012

Análise do índice de complexidade do Google+ para o trabalho em equipe no ano de 2012 demonstra que $65 \%$ dos estudantes do $2^{\circ}$ ano, $78 \%$ dos estudantes do $4^{\circ}$ ano e $56 \%$ dos estudantes de pós-graduação não se adaptaram à complexidade das mídias sociais incorporadas nesse ambiente, índices que poderiam ter sido revertidos se o estímulo intelectual e a motivação para esse desafio houvessem sido trabalhados nos estudantes com o intuito de os fazerem superarem-se e evoluírem rumo a um diferencial futuro, que os capacitassem em relação às adaptações necessárias decorridos dos sistemas complexos. Em se tratando do Moodle, mesmo o fato de este ambiente ter sido analisado como um ambiente muito desorganizado nas atividades de 2012, não é visto como um ambiente difícil de se trabalhar, tendo $57 \%$ dos estudantes do $2^{\circ}$ ano, $45 \%$ dos estudantes do $4^{\circ}$ ano e $78 \%$ dos estudantes de pós-graduação avaliado o mesmo como "confortável" (Figura 42).

Fica claro que independente da complexidade do sistema, os estudantes podem se adaptar à essa complexidade e dela tirarem a motivação necessária para realizarem suas tarefas com qualidade. 


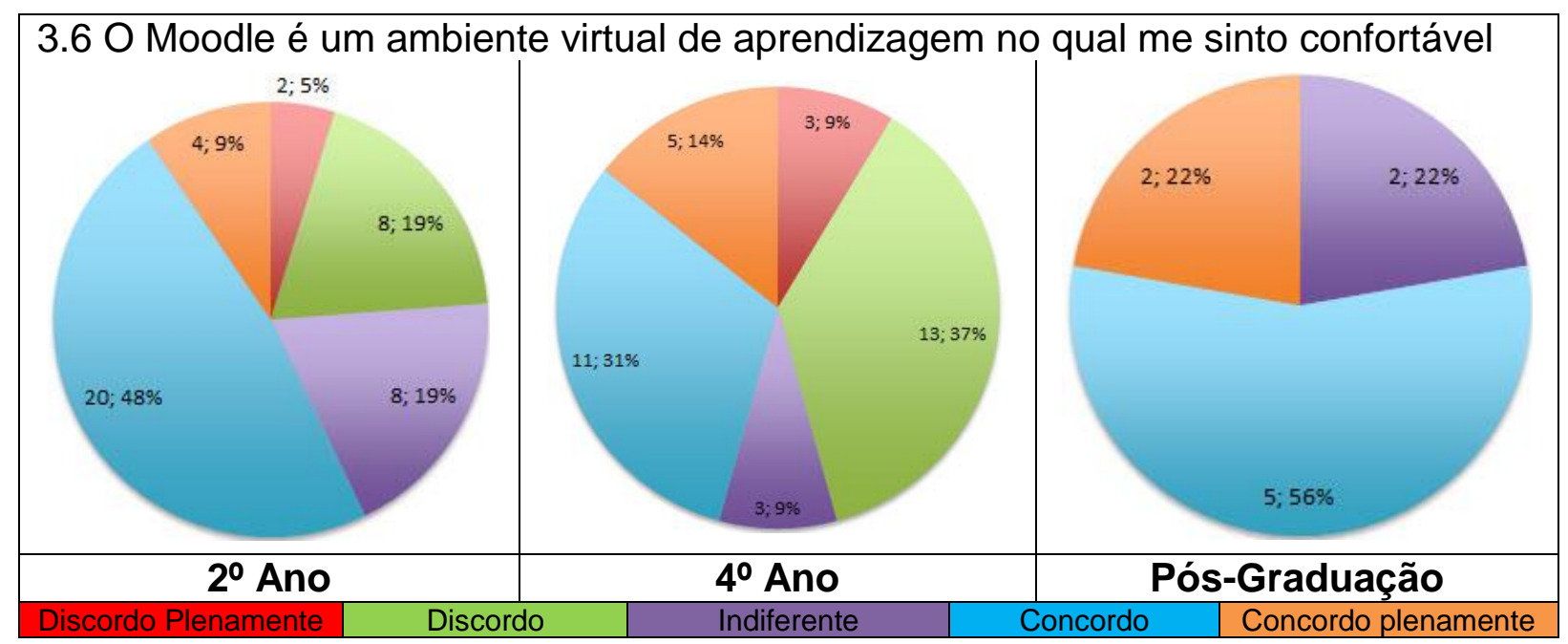

Figura 42 - Análise do índice de motivação ao se trabalhar com o Moodle no ano de 2012

O responsável em descomplicar o que é visto como complexo não há de vir de uma liderança Laissez-faire, que como visto é fonte de desmotivação quando se trabalha em equipe na engenharia. O e-líder, responsável a conduzir equipes em ambientes virtuais com amparo da TIC, necessita de um perfil de liderança que motive os estudantes a superarem o complexo, e para transpor essa ponte, a liderança transformacional se mostra a mais viável.

\subsection{Observações finais}

A análise dos resultados apontou caminhos que se bem trabalhados podem ser disseminados a outras disciplinas e departamentos. A observação de aspectos inerentes aos processos de conversão do conhecimento com apoio da TIC em ambientes híbridos como suporte à disseminação de conhecimentos tácitos e explícitos se mostrou proeminente uma vez que são processos necessários para o docente trabalhar com qualidade e segurança nos tempos atuais.

Quando bem observado os gráficos obtidos pelas respostas das questões referentes ao perfil de liderança do docente em sala de aula (figuras de 17 a 24) os 
estudantes da pós-graduação mostraram-se mais aptos a se adaptarem às circunstâncias exigidas pelo PBL, até mesmo contribuindo com ideias que estão sendo analisadas para já serem implantadas na pós-graduação, como uma aula ministrada em inglês, o que vem ao encontro da globalização que a Universidade de São Paulo está buscando:

Trabalho com sistemas de gerência de pavimentos e certamente usarei muitos conceitos aqui explorados na vida acadêmica e profissional. Como sugestão, em pelo menos uma aula, o conteúdo poderá ser exposto em língua inglesa (no início do curso) (2011_SAD_PósG03_Alun01).

Mesmo tendo utilizado de um mesmo perfil de liderança em todas as disciplinas, ficou claro a necessidade de se levar em consideração o grau de amadurecimento dos estudantes no quesito entendimento das ações do docente.

Em relação aos ambientes virtuais de aprendizagem, como no Google+, o Facebook e o Moodle, o perfil de liderança do docente observado, aponta também para uma liderança Laissez-faire. Resultados pouco expressivos e perda de oportunidades de aprendizagem pelas equipes, que deixaram de utilizar muitas mídias sociais importantes para um trabalho em equipe com qualidade, e que estão presentes nestes ambientes, colocam esse perfil de liderança como pouco efetivo na condução de equipes em ambientes virtuais. O estilo de liderança Laissez-faire do docente ocasionou um processo em cadeia de desmotivação das classes, com ênfase na graduação. Comentários muito pouco frequentes em atividades com os membros, a menos que questionado, e escassas tentativas para participar ou interferir com o curso dos acontecimentos, somados a uma completa liberdade para os grupos ou decisão individual, geraram frustração, desmotivação, desorientação e perda de foco dos estudantes para com a ementa das disciplinas pesquisadas. A 
importância de uma visão sistêmica do docente para se entender a complexidade das partes é visto como um fator crítico de sucesso na condução de equipes em ambientes virtuais na engenharia, uma vez que permite uma ação antes de uma reação negativa por parte dos estudantes. Cabe ao docente, diante do grande arsenal de recursos tecnológicos e de liderança disponibilizados, assumir sua responsabilidade enquanto líder em ambientes híbridos de aprendizagem, motivando, assessorando, instigando, conduzindo e orientando os estudantes em cada contexto. A liderança transformacional aponta como um recurso valioso a ser utilizada pelos docente da engenharia em ambientes virtuais de colaboração devido a grande abrangência por meio de suas dimensões, como a motivação inspiradora, estimulação intelectual e consideração individualizada, alcançando os estudantes por meio de uma visão holística do seu contexto de atuação. Traços de uma liderança transacional também apontam como diferencial no momento que cobranças e uma atuação antes que um problema se consolide pode combater dificuldades encontradas durante os processos de aprendizagem. Assim sendo, a liderança Laissez-faire repercutiu negativamente junto aos estudantes da graduação e da pós-graduação, podendo mesmo ser descartada diante dos desafios do novo milênio, que exige dos profissionais da educação um comportamento proativo, com comunicação assertiva e uma visão sistêmica da sala de aula.

Dificuldades dos estudantes em saberem o que deveria ser feito demonstra falta de alinhamento dos objetivos, da ementa da disciplina, da monitoria e do docente para com os estudantes. O estudante 2011_SI_G02_Alun02 aponta, inclusive, que recompensas e punições não foram apregoadas pelo docente no controle da sala. A Wiki do Moodle mostrou-se muito válida no trabalho em equipe em um ambiente adverso, uma vez que proporciona maior controle do conteúdo 
gerado pelo grupo, o que não eliminou a desmotivação no contexto estudado. Muitos desses problemas são descritos no discurso dos seguintes estudantes:

Acredito que um acompanhamento mais eficiente por parte do docente resultaria em uma melhor organização e fluidez da disciplina. Quando as atividades não são determinadas claramente, nem os critérios de avaliação, a equipe não se sente confortável e nem confiante se está fazendo um trabalho de qualidade. Creio que o docente deveria ter usado mais o Moodle para divulgação dos afazeres, recompensas, punições, etc. (2011_SI_G02_Alun02).

Durante a disciplina tivemos dificuldades em saber o que deveríamos fazer para a aula seguinte, o que deveríamos pesquisar e se tínhamos que montar uma apresentação ou não. Por duas vezes montamos um Slide-show e esquematizamos uma apresentação, mas não tivemos a oportunidade de fazê-lo. O Moodle poderia ter sido melhor utilizado com instruções do que deveríamos fazer a cada semana, além de um cronograma fixo, possivelmente com a data de cada apresentação. Um ponto positivo da disciplina foi a realização dos trabalhos principais através das Wikis, que possibilitou uma melhor organização do que estava sendo e o que já havia sido feito (2011_SI_G02_Alun04).

O estudante 2011_SI_G07_Alun05 apontou que o Moodle poderia ter sido utilizado para a divulgação das notas logo em seguida às atividades para poderem mensurar se estavam caminhando corretamente, pois a lacuna dessa percepção parece ter sido um dos grandes problemas enfrentando pela classe.

No aspecto do Moodle, poderiam ser colocadas as notas de acordo com o andamento do curso, para que os estudantes pudessem acompanhar seu rendimento (2011_SI_G07_Alun05). 
Podemos observar que o fator liderança emerge novamente como norteador também em um ambiente virtual de aprendizagem consolidado, como o Moodle. Uma liderança transformacional é mais facilmente observável em condições adversas, onde membros de um time se encontram desorientados e buscam um alicerce nos traços de personalidade que melhor se adequar a determinados contextos, papel que o docente deve desempenhar.

O treinamento nas ferramentas também se mostrou preponderante. Não se pode apostar em conhecimento prévio do estudante. Existem vários níveis de conhecimento e curvas de aprendizagem e a realidade de cada pessoa se difere de outra mesmo em mesmos contextos, por mais simples que possam parecer. Mesmo havendo uma palestra com exemplos práticos proferida pelo monitor da disciplina de como funciona o Google+ na tentativa de criar um conhecimento básico para posterior consolidação, não foi o suficiente, conforme o discurso do estudante 2011_SAD_PósG01_Alun04 da pós-graduação.

Gostei muito da disciplina e espero participar de outras. Sugiro uma aula inicial de instrução para a utilização do Google+, assim poderíamos fazer melhor proveito dos serviços oferecidos na ferramenta (2011_SAD_PósG01_Alun04).

Relevante observar que estudantes da pós-graduação se dividiram em relação às dificuldades que encontraram no Google+, conforme observado na figura 35, o que deixa nítido que mesmo em uma classe de pós-graduação de uma disciplina de tecnologia da informação, o ambiente virtual de colaboração deve ser inserido com cautela, pois presentes na sala estarão estudantes com vivências e visões de mundo diferentes, nuances a serem identificadas e bem trabalhadas pelo docente, enquanto líder. 
Importante frisar que do total de recursos do Google+ utilizados pelos estudantes da engenharia de produção da EESC-USP, os grupos melhores avaliados no final do semestre foram os que utilizaram esse ambiente com uma constância superior aos grupos com as piores avaliações, sem que este fato tenha repercutido na avaliação do docente, o que demonstra que a nota final dos estudantes inseridos nesses grupos foi diretamente proporcional ao grau de comprometimento para com as orientações iniciais do docente na utilização das mídias sociais presentes neste ambiente, mesmo sem a cobrança do mesmo no decorrer do semestre. Esse fato caracteriza pró-atividade das equipes melhores avaliadas e sinalização de uma necessidade de atuação individual, estimulo intelectual e motivação para com as equipes sem este perfil proativo, dimensões de uma liderança transformacional não observada no docente nos contextos estudados, que pode ter acarretado em perda de oportunidades de aprendizagem para estes estudantes. Cabe enfatizar que, pelas observações do pesquisador em sala de aula e nos ambientes virtuais, a utilização do método PBL foi preponderante na avaliação do perfil de liderança do docente nos ambientes híbridos.

Não obstante, se observarmos os resultados de uma forma holística e com pensamento crítico, o PBL pode até ter alcançado o resultado esperado quando se propõe a fazer do estudante gestor de seu próprio aprendizado, quando observado o discurso do estudante 2011_SI_G03_Alun03, mas os resultados como um todo indicam a necessidade por parte desses estudantes de um acompanhamento de perto e sequencial em relação aos avanços em prol da consolidação do aprendizado.

Não nos foi explicada a matéria nem o seu conteúdo, ficando a cargo de cada estudante pesquisar sobre 0 assunto e a autoaprendizagem (2011_SI_G03_Alun03). 
O que faltou foi um maior direcionamento dessa autoaprendizagem enfatizada pelo estudante 2011_SI_G03_Alun03, que poderia ter sido feita por meio de micro intervenções de acordo com a dinâmica das aulas, o que é preconizado como positivo na literatura (SPRINGER; STANNE; DONOVAN, 1999).

\section{CONSIDERAÇÕES FINAIS}

\subsection{Conclusões do trabalho}

Em relação à pergunta norteadora, conclui-se que a influencia da liderança do docente na motivação dos estudantes, na resolução de problemas reais de engenharia com uso de PBL em ambientes híbridos de aprendizagem apoiados pela tecnologia de informação e comunicação, é um fator crítico de sucesso. Assim, o objetivo de identificar o estilo de liderança do docente e a motivação gerada nos estudantes na resolução de problemas reais de engenharia, com uso de PBL em ambientes híbridos de aprendizagem, apoiados pela tecnologia de informação e comunicação, foi alcançado, uma vez que o estilo Laissez-faire identificado gerou desmotivação e perdas de possibilidades de aprendizagem, com ênfase na graduação, e a liderança situacional surgiu como resposta para combater esse problema. Para isso foi necessário a compreensão das inter-relações contextuais provenientes dos sistemas complexos, no processo ensino-aprendizagem, assim como a análise da importância da dimensão da tecnologia da informação e comunicação (TIC), como as mídias sociais. 
Aprofundando-se mais, os resultados foram interpretados e discutidos, gerando uma conclusão que se dá a partir da perspectiva de se ter tentado estabelecer um elo entre a pesquisa e a prática educativa.

Nesse processo de pesquisa, o referencial teórico, que visa fornecer o alicerce para a fundamentação das análises críticas, teve de atentar-se para assuntos que vislumbrassem a aquisição pelo pesquisador de uma visão holística da complexidade do problema e do objetivo da pesquisa. Por meio desta visão sistêmica, que somada aos novos conhecimentos adquiridos pela análise do índice de satisfação de grupo, das figuras e do discurso dos estudantes, surge a possibilidade, pelos resultados obtidos, de acrescentar uma nova visão para uma possível evolução do processo ensino-aprendizagem na engenharia, pela inserção do elemento liderança situacional do docente no cenário. Os resultados, ao fornecerem subsídios consistentes, indicam a necessidade emergencial de uma mudança de comportamento do docente analisado nos anos de 2011 e 2012 na fase de implantação do PBL em ambientes híbridos de aprendizagem, na qual, mesmo sem ter o conhecimento, atuou com um estilo Laissez-faire de liderança, ocasionando perda de interesse nos temas de aula pelos estudantes, desmotivação e conflitos, com ênfase nos estudantes de graduação, sendo a TIC subutilizada e não capaz de gerar motivação pela ausência da liderança necessária. Esses problemas, como observado, estão fundamentados na dificuldade de mudança do paradigma tradicional da educação, voltado ao conteúdo e sistematização do processo ensino-aprendizagem, no tamanho das salas de aula e número de estudantes, e no correto entendimento e utilização da TIC em ambientes híbridos de aprendizagem. A mudança demanda alterações na estrutura e cultura da organização estudada. 
Para a obtenção da visão sistêmica necessária para a interpretação dos contextos de aula, os temas mais pertinentes, na visão do pesquisador, foram revisados, como: Inteligência Emocional; Conhecimento; Sistemas Complexos; Teorias da Liderança; Motivação e Princípios de Aprendizagem; Mídias Sociais; Ambientes Híbridos e o PBL. Assim, os resultados advindos da complexidade das inter-relações entre os elementos inseridos nos contextos estudados mostram-se fundamentais no momento que apontam uma necessidade de assimilação de seus corretos entendimentos por agentes facilitadores em processos de capacitação de docentes da engenharia em dimensões de uma liderança mais efetiva na fase de implantação do PBL. A correta interpretação dos resultados negativos advindos de uma liderança Laissez-faire permite a tentativa da utilização de outras abordagens e a elaboração de estratégias para obtenção de um todo organizado, onde os ambientes híbridos de aprendizagem atuem como fonte de integração, e não de dispersão, como observado. Inserir a inteligência emocional, como competência necessária ao docente frente a diferentes contextos de aula ministradas pelo método PBL, demonstra ser um fator crítico para o sucesso do mesmo como líder eficiente, na medida em que alavanca suas aptidões mais intrínsecas na condução de uma disciplina, cobrindo a lacuna da estagnação, ainda mais quando apoiados pela TIC, que estende a complexidade do sistema. A interpretação das variantes inseridas na conversão entre os conhecimentos tácitos e explícitos no estudo, e como o conhecimento individual e coletivo era construído ou adquirido, contribuiu para um melhor entendimento dos processos de transferência e compartilhamento de conhecimentos entre os estudantes, além da influencia do docente. As teorias da liderança forneceram importantes informações comportamentais para o 
entendimento de como o docente pode melhor adequar-se a contextos de aula em uma sociedade regida pela velocidade das mudanças.

Entre os estilos de liderança consolidadas por pesquisas cientificas como fomentadoras de melhores resultados no desempenho individual e de equipes, aparecem a Liderança Transformacional e a Liderança Transacional, com vantagem para a liderança transformacional no momento que semeia resultados além dos esperados. Essa conclusão induz o pesquisador a afirmar que a quebra do paradigma tradicional do processo ensino-aprendizagem para o PBL pode ter como agente intermediador uma liderança situacional nos ambientes híbridos, ora utilizando-se do perfil Transformacional, ora do perfil Transacional.

Evidencia-se no discurso escrito dos estudantes analisados, que grande parte destes não estão preparados para serem responsáveis pela construção do próprio conhecimento em ambientes híbridos de aprendizagem, como apregoa o PBL. Se o docente agir com muita passividade e pouca interferência, o nível de motivação dos estudantes tende a cair exponencialmente ao lidarem com problemas reais. O knowhow do docente deve nortear os estudantes em grande parte do tempo, uma vez que é por meio dele que processos de transferência e compartilhamento de conhecimento acontecem. O docente deve atuar como facilitador frente aos estudantes, não à margem dos mesmos como muito se fez, interpretando como sendo o certo no momento de se implantar o PBL em uma IES. Mais uma vez enfatiza-se que essa observação é menos evidente nos estudantes de pósgraduação.

Fica concluso que, na problemática vislumbrada ao trabalhar-se com o PBL em ambientes híbridos na engenharia, cabe ao docente, enquanto líder, ser o elo integrador entre os estudantes e o método de aula, enfatizando de forma proativa os 
passos para a correta aplicação do método, elucidando os termos difíceis, definindo claramente os problemas a serem entendidos (que demandam uma correta explicação), analisando criticamente os problemas e fornecendo possíveis explicações individuais e para o grupo, de acordo com os conhecimentos prévios dos mesmos, que são identificados por meio de estratégias como o Brainstorming. Cabe ao docente também resumir os avanços alcançados, formular claramente os objetivos de aprendizado de acordo com os problemas, sempre focando no objetivo principal da aula, que é o aprendizado do estudante, relatando os avanços observados a cada grupo, e até mesmo individualmente, para discussão e consolidação do entendimento. Uma liderança Laissez-faire não colabora para esses processos de feedback na medida em que cria uma lacuna entre os estudantes e o docente pelo excesso de liberdade dada a eles. Ficou claramente percebido que o entendimento pelo docente dos contextos de aula, por meio de uma visão holística desse sistema complexo, passa a ser um fator impactante no sucesso da criação ou aquisição do conhecimento pelo estudante nas IES, o que um aprofundamento no entendimento dos conceitos de Inteligência Emocional, dos perfis de aprendizagem dos alunos, e dos fatores que os motivam, pode contribuir.

Reforça-se, pois, na conclusão do presente trabalho, no contexto estudado, que o docente pode conduzir os estudantes a um aprendizado que extrapole o alcançado pelos processos tradicionais de ensino-aprendizagem, que visam mais a disseminação de informações do que a criação ou aquisição do conhecimento, se atuar com perfis de lideranças adequados a cada contexto, ou seja, com uma liderança situacional, onde a liderança transformacional e a transacional se alternem. O docente torna-se a ponte entre o antes e o depois, fomentando o pensamento crítico nos estudantes sem deixa-los em um primeiro momento livres 
para atuarem da maneira que melhor se ajustarem, como apregoa o estilo de liderança Laissez-faire. Como afirmado pela teoria da complexidade, quando foca os sistemas complexos adaptativos, o sistema é altamente sensível às condições iniciais, tem memória e inclui feedback (JOHNSON, 2007), o que permite também concluir que o docente deve atuar como líder transformacional e transacional (quando necessário) desde o inicio das atividades acadêmicas, evitando que o sistema se adapte às condições adversas advindas do estilo de liderança Laissezfaire, que demanda uma energia considerável do docente para reverter o processo em momentos mais adiantados do semestre, com retrabalhos, aulas de reforço e gerenciamento de conflitos. Ainda é notória a necessidade de grande parte dos estudantes da engenharia serem educados sequencialmente, sendo que a mudança para um autogerenciamento das equipes por meio do PBL deve ser inserida no ambiente de aula da engenharia de forma gradual, principalmente na graduação. Uma mudança radical do paradigma tradicional do ensino pode gerar confusão e perdas de oportunidades de aprendizagem, e assim sendo, nas primeiras semanas de aula é perspicaz que o docente ministre a aula de acordo com o paradigma tradicional, sem que para isso tenha de se abster de formas criativas de passar o conteúdo, o que pode ser feito utilizando-se da TIC. Conclui-se também que a transição para o PBL seja efetuada no decorrer do semestre e por explicações detalhadas do porque e como o método funciona, instigando os alunos a entenderem a necessidade de ultrapassarem a barreira do tradicional em prol de sua própria formação profissional. Segundo este estudo, a criação de um ambiente propício ao aprendizado, por meio do método PBL na engenharia, ainda passa pela necessidade de elaboração de um alicerce sólido em relação à estratégia para a aprendizagem da disciplina, com as mudanças graduais sendo amparadas, nas 
primeiras semanas de aula, ainda por conceitos do paradigma tradicional, sugerindose:

- Metas claras dos métodos de avaliação

- Metas claras quanto aos objetivos semanais a serem entregues e como os resultados devem ser apresentados

- Instruções de como se atingir os objetivos por meio de uma ementa detalhada

- Calendários bem definidos de entrega de trabalhos

- Feedbacks constantes

- Capacitação dos estudantes frente aos ambientes virtuais a serem utilizados

- Maior número de aulas práticas, de preferência com cases contendo problemas reais e do cotidiano

- Melhor organização didática dos ambientes virtuais

- Supervisão constante dos ambientes virtuais para dar suporte aos alunos em caso de instabilidade dos sistemas, que causa muito stress nos mesmos

- Delimitação do papel dos monitores com fins de se evitar que ocupem - lugar do docente no processo ensino-aprendizagem, gerando conflitos de entendimento entre estes, o docente e os estudantes

- Atenção quanto aos perfis de aprendizagem dos estudantes, ministrando-se aulas de maneiras criativas e variadas, para que estudantes de diversos perfis sejam beneficiados

- Manutenção de um caminho sólido na condução das tarefas, sem mudanças bruscas dos objetivos inerentes às aulas, principalmente em 
relação a como os estudantes estão sendo avaliados e o que eles devem fazer para obterem a avaliação

- Fornecer indicadores pelos quais o estudante possa interpretar seu desempenho, como feedbacks individuais e/ou de grupo tanto por meio dos ambientes presenciais como nos virtuais

- Conduzir os estudantes com atenção na utilização de mídias sociais durante as aulas expositivas para se evitar dispersão e confusão, ou que o foco dos mesmos fique apenas em um dos métodos de acesso a informação, uma vez que foi observado durante a pesquisa que a maioria dos estudantes que acessam as mídias sociais durante aulas expositivas não prestam atenção ao que o docente está dizendo

Essas premissas contrastam de certa forma com a filosofia do método PBL, da busca do pensamento crítico por parte dos estudantes na resolução de problemas reais, sem que para isso tenham de temer métodos de avaliação ou a nota em si, mas são fundamentalmente importantes nas primeiras semanas de aula.

Finalizando, as diferenças observadas no índice de motivação dos grupos entre as classes do $2^{\circ}$ ano, do $4^{\circ}$ ano e da pós-graduação, também indicam que 0 docente necessita de uma visão holística e uma liderança situacional, uma vez que atuando como Laissez-faire, gerou diferentes índices de motivação, o que pode indicar que a maturidade dos estudantes pode gerar motivações intrínsecas não observáveis. A maturidade entre novatos e especialistas, indicada na figura 3, pág. 74, pode explicar essas diferenças no índice de motivação dos grupos, o que é corroborado pelos resultados positivos advindos dos estudantes de pós-graduação no final dos semestres de aula. 


\subsection{Limitações do estudo}

Estudo realizado apenas no Departamento de Engenharia de Produção da EESC-USP, com apenas um docente como líder das disciplinas.

\subsection{Sugestões para trabalhos futuros}

A utilização do questionário em outras disciplinas da engenharia permitiria a análise das variáveis em outros contextos, consolidando ou não as percepções observadas neste trabalho, como a influência do PBL no processo ensinoaprendizagem na engenharia, a influência do perfil de liderança apresentado pelo docente nos níveis de motivação no caminho para os objetivos das disciplinas e também como as Mídias Sociais tem sido utilizadas pelos estudantes. Pesquisar as dificuldades do docente na fase de implantação do PBL também são pertinentes, como os elementos que podem influir em sua atuação como líder proativo, entre elas os inúmeros afazeres que o docente desempenha em uma IES, a quantidade de alunos e dificuldades de atuar em ambientes híbridos. Cabe pesquisar em trabalhos futuros a análise da visão do docente para com os acontecimentos em ambientes híbridos, uma vez que o seu ponto de vista integrado ao dos estudantes, pode resultar em um manual de boas práticas para a fase de implantação do PBL na engenharia. Observações mais aprofundadas nessas áreas podem vir a incorrer em um maior entendimento para com a inteligência coletiva e individual dos estudantes em ambientes complexos, fornecendo elementos para uma aproximação estudantedocente que permita a extrapolação do aprendizado de ambos para além muros, fomentando uma transformação não apenas intelectual, mas também mental e espiritual, que repercuta para uma sociedade mais ciente de seus deveres e obrigações. 


\section{REFERÊNCIAS}

ALBANESE,M.A.; MITCHELL, S. (1993). Problem-based learning: a review of literature on its outcomes and implementation issues. Academic Medicine, v.68, n.1, p.52-81, Jan.

ALLAN, K. (1998). Leadership traits reveal themselves to the aware. Business First - Columbus, v.14, n.24, p.1-5.

ALLPORT, G.W.; ODBERT, H.S. (1936). Trait-names: a psycho-lexical study. Psychological Monographs, v.47, n.211, p.1-171

ANCONA, D. et al. (1999). Organizational behavior and processes. Boston: South-Western College.

APRENDE educação para o novo milênio. (2012). Disponível em:<http://www.prod.eesc.usp.br/aprende/mapeamento.htm>. Acesso em: 16 jan. 2012.

AVOLIO, B.J.; KAHAI, S.S. (2002). Placing the "E" in e-leadership: minor tweak or fundamental change. In: MURPHY, S.E.; RIGGIO, R.E. (Ed.). The Future of leadership development. Mahwah: Lawrence Erlbaum. p.49-70.

AVOLIO, B.J.; BASS, B.M.; JUNG, D.I. (1999). Re-examining the components of transformational and transactional leadership using the multifactor leadership questionnaire. Journal of Occupational and Organizational Psychology, v.72, n.4, p.441-462.

BASS, B.M. (1985). Leadership: good, better, best. Organizational Dynamics, v.13, n.3, p.26-40.

BASS, B.M.; AVOLIO, B.J. (1994). Improving organizational effectiveness through transformational leadership. Thousand Oaks: Sage. p.1-9

BASS, B.M.; STEIDLMEIER, P. (1999). Ethics, character, and authentic transformational leadership behavior. The Leadership Quarterly, Amsterdam, v.10, n.2, p.181-217.

BEELAND JR., W.D. (2002). Student engagement, visual learning and technology: can interactive whiteboards help?. Action Research Exchange, v.1, n.1, Summer.

BELL, B.S.; KOZLOWSKI, S.W.J. (2002). A Typology of virtual teams implications for effective leadership. Group and Organization Management, Thousand Oaks, v.27, n.1, p.14-49, Mar.

BELL, D. (1976). O Advento da sociedade pós-industrial: uma tentativa de previsão social. São Paulo: Abril Cultural. 
BERBEL, N.N. (1988). "Problematization" and problem-based learning: different words or different ways? Interface. Comunicação, Saúde, Educação, v.2, n.2, p.

BLAKE, R.; MOUTON, J. (1964). The Managerial grid: the key to leadership excellence. Houston: Gulf.

Houston: Gulf.

(1985). The Managerial grid III: the key to leadership excellence.

BLUEDORN, A. (2002). Images of planning, performance, and other theory. In: YAMMARINO, F.; DANSEREAU, F. (Ed.). Multi-level issues in organizational behavior and processes. Greenwich: JAI. p.67-72.

BOEREE, C.G. (2006). Personality theories: Albert Bandura. Disponível em:< http://webspace.ship.edu/cgboer/bandura.html >. Acesso em: 31 mar.2012.

BOISOT, M.H. (1998). Knowledge assets: securing competitive advantage in the information economy. New York: Oxford University Press.

(2002). The Creation and sharing of knowledge. In: CHOO, C.W.;

BONTIS, N. (Ed.). The Strategic management of intellectual capital and organizational knowledge. New York: Oxford University Press. p.65-77.

BOUND, D.; FELETTI, G. (1998). The Challenge of problem-based learning. $2^{\text {nd }}$ ed. London: Kongan Page.

BRAKE, T. (2009). Where in the world is my team: making a success of your virtual global workplace. Hoboken: Wiley.

BROWN, J.D. (2000). What issues affect likert-scale questionnaire formats?. Shiken: JALT testing \& evaluation SIG Newsletter, v.4, n.1, p.27-30, Apr.

BROWN, M.E.; GIOIA, D.A. (2002). Making things click: distributive leadership in an online division of an offline organization. Leadership Quarterly, v.13, n.4, p.397-420.

BRUCE, J. C. (2003) Popper and Hayek: Who influenced whom? (http:/ / www. unites. uqam. ca/ philo/pdf/ Caldwell_2003-01. pdf), Karl Popper 2002 Centenary Congress, 2002.

BRYMAN, A. (2004). Qualitative research on leadership: a critical but appreciative review. The Leadership Quarterly, v.15, n.6, p.729-769.

. (2007a). Effective leadership in higher education. London: Leadership

Foundation for Higher Education. (Research and Development Series).

(2007b). Effective leadership in higher education: a literature review.

Studies in Higher Education, v.32, n.6, p.693-710. 
BUARQUE, C. (1994). A Aventura da Universidade. São Paulo: Ed.UNESP; Rio de Janeiro: Paz e Terra.

BURNS, J.M. (1978). Leadership. New York: Plenum.

CALDWELL, B.J. (2003). Popper and hayek: who influenced whom?. Cahiers D’Épistémiologie, n.2003-1-292. Disponível

em:<http://www.unites.uqam.ca/philo/pdf/Caldwell_2003-01.pdf>. Acesso em: 02 Mar 2012

CARLYLE, T. (1888). On Heroes, hero-worship and the heroic in history. New York: Fredrick A. Stokes

CARUSO, D.R.; SALOVEY, P. (2004). The Emotionally intelligent manager: how to develop and use the four key emotional skills of leadership. San Francisco: Jossey-Bass.

CASCIO, W.F.; SHURYGAILO, S. (2003). E-leadership and virtual teams. Organizational Dynamics, Amsterdam, v.31, n.4, p.362-376.

CATTELL, R.B. (1965). The Ccientific analysis of personality. Baltimore: Penguin Books.

CHESBROUGH, H. (2006). Open business models: how to thrive in the new innovation landscape. Boston: Harvard Business School Press.

CHI, M.T.; GLASER, R.; REES, E. (1982). Expertise in problem solving. In: STERNBERG, R. (Ed.). Advances in the psychology of human intelligence. Hillsdale: Erlbaum. p.7-76.

CHICKERING, A.W.; GAMSON, Z.F. (1987). Seven principles for good practice in undergraduate education. AAHE Bulletin, n.3, p 3-7., Mar.

CHOO, C.W.; BONTIS, N. (2002). The Strategic management of intellectual capital and organizational knowledge. New York: Oxford University Press.

COHEN, S.G.; MANKIN, D. (1999). Collaboration in the virtual organization. New York: John Wiley.

COHEN, D.; PRUSAK, L. (2001). Good company: how social capital makes organizations work. Boston: Harvard Business School Press.

COVEY, S.R. (1989). The Seven habits of highly effective people: powerful lessons in personal change. New York: Fireside/Simon \& Schuster.

COVEY, S.R. (1991). Principle-centered leadership. New York: Fireside/Simon \& Schuster.

CYRINO, E.G.; TORALLES-PEREIRA, M.L. (2004). Trabalhando com estratégias de ensino-aprendizado por descoberta na área da saúde: a problematização e a 
aprendizagem baseada em problemas. Caderno de Saúde Pública, v.20, n.3, p.780-8.

DAFT, R.L. (2001). The Leadership experience. Fort Worth: Harcourt College.

DAFT, R.L.; LENGEL, R.H. (1998). Fusion leadership: unlocking the subtle forces that change people and organization. San Francisco: Berrett-Koehler.

DALAI LAMA XIV. (1999). Ethics for the new millennium. New York: Putnam.

DAVENPORT, T.H.; PRUSAK, L. (2000). Working knowledge: how organizations manage what theyknow. Bosotn: Harvard Business School Press.

DE CORTE, E. (1990). Toward powerful learning environments for the acquisition of problem-solving skills. European Journal of Psychology of Education, v.5, n.1, p.5-19.

DEROSA, D.M. et al. (2004). Trust and leadership in virtual teamwork: a media naturalness perspective. Human Resource Management, Hoboken, v.43, n.2/3, p.219-232, Summer.

DESANCTIS, G.; POOLE, M. (1994) Capturing the complexity in advanced technology use: Adaptive structuration theory. Organization Science, 1994, Número 5, p.121-147.

DESHAIES, B. (1992). Metodologia da investigação em ciências humanas. Lisboa: Instituto Piaget.

DIRKS, K.T.; FERRIN, D.L. (2002). Trust in leadership: meta-analytic findings and implications for research and practice. Journal of Applied Psychology, Washington, v.87, n.4, p.611-628, Aug.

DOCHY,F.; SEGERS, M.; BUEHL, M.M. (1999). The Relation between assessment practices and outcomes of studies: the case of research on prior knowledge. Review of Educational Research, v.69, n.2, p.145-186.

DRUCKER, P. (1993). Post capitalist society. New York: Harper Collins.

DUFOUR, Y.; STEANE, P. (2007). Implementing knowledge management: a more robust model. Journal of Knowledge Management, v.11, n.6, p.68-80.

DURNEY, C.H. (1973). A Review: principles of design and analysis of learning systems. Engineering Education, n.406, p. 13 , Mar.

EAGLY, A.H.; ENGEN, M.L.; JOHANNESEN-SCHMIDT, M.C. (2003).

Transformational, transactional, and laissez-faire leadership styles: a meta-analysis comparing women and men. Psychological Bulletin, v.129, n.4, p.569-591.

DOI: 10.1037/0033-2909.129.4.569.

EBLE, K.E. (1988). The Craft of teaching. $2^{\text {nd }}$ ed. San Francisco: Jossey-Bass. 
ELBOW, P. (1986). Embracing contraries: explorations in learning and teaching. New York: Oxford University Press. Chap.7.

ELLIS, C.; GIBBS, S.; REIN, G. (1991). Groupware: some issues and experiences. Communications of the ACM, New York, v.34, n.1, p.38-58.

ENGEL,C.E. Not just a method but a way of learning. In: BOUND, D.; FELETTI, G. (Ed.). The Challenge of problem based learning. $2^{\text {nd }}$ ed. London: Kogan, 1997. p.17-27.

ERICKSON, S.C. (1974). Motivation for learning. Ann Arbor: The University of Michigan Press.

ESCRIVÃO FILHO, E.; RIBEIRO, L.R.C. (2007). Inovando no ensino de administração: uma experiência com a aprendizagem baseada em problemas (PBL). In: ENCONTRO DE ENSINO E PESQUISA EM ADMINISTRAÇÃO E CONTABILIDADE, 2007, Recife. Anais... Recife: [s.n.]. p.10 .

EYSENCK, H.J. (1992). Four ways five factors are not basic. Personality and Individual Differences, v.13,n. , p.667-673.

FELDER, R.M. (1996). Matters of style. ASEE Prism, v.6, n.4, p.18-23.

FELDER, R.M.; BRENT, R. (2005). Understanding student differences. Journal of Engineering Education, v.94, n.1, p.57-72.

FELDER, R.M.; SILVERMAN, L.K. (1988). Learning and teaching styles in engineering education. Journal of Engineering Education, v.78, n.7, p.674-681, Apr.

FERRIS, R. (1988). How the power of love can improve leadership.

Organizational Dynamics, v.16, n.4, p.40-52.

FINKELSTEIN, S. (2002). Planning in organizations: one vote for complexity. In: YAMMARINO, F.; DANSEREUA, F. (Ed.). Multi-level Issues in organizational behavior and processes. Oxford: Elsevier. p.73-80.

FLEISHMAN, E.A. (1953). The Description of supervisory behavior. Journal of Applied Psychology, v.37, n. 2 , p.153-158.

FONTANA, A.; FREY, J.H. (1994). Interviewing: the art of science. In: DENZÏN, N.K.; LINCOLN, Y.S. Handbook of qualitative research. Thousand Oaks: Sage. p.361.

FRIEDMAN, R.S.; DEEK, F.P. (2002). The Integration of problem-based learning and problem solving tools to support distributed education environments. In: ASEE/IEEE FRONTIERS IN EDUCATION CONFERENCE, 32., 2002, Boston. Proceedings... New York: IEEE. 
FRIEDRICH, C.J. (1961). Political leadership and the problem of the charismatic power. The Journal of Politics, v.23, n.2 , p.3-24.

FRY, L.W. (2003). Toward a theory of spiritual leadership. Leadership Quarterly, v.14, n.6, p.693-727, Dec.

GEORGE, J.M. (2000). Emotions and leadership: the role of emotional intelligence. Human Relations, v.53, n.8, p.1027-1055.

GIL, A.C. (2005). Metodologia do ensino superior. 4.ed. São Paulo: Atlas.

GIL, A.C. (1999). Métodos e técnicas de pesquisa social. 5.ed. São Paulo: Atlas.

GLEICK, J. (1987). Chaos: making a new science. London: Cardinal.

GOULD, T. (2003). Hybrid classes: maximizing institutional resources and student learning. In: ASCUE CONFERENCE, 2003, Myrtle Beach. Proceedings... [S.I.:s.n.]. p.54-59.

GRANT, R.M. (2002). The Knowledge-based view of the firm. CHOO, C.W.; BONTIS, N. (2002). The Strategic management of intellectual capital and organizational knowledge. New York: Oxford University Press. p. 133-148

GRENIER, R.; METES, G. (1995). Going virtual: moving your organization into the 21st century. Upper Saddle River: Prentice Hall.

GRONN, P. (2002). Distributed leadership as a unit of analysis. Leadership Quarterly, v.13, n. 4 , p.423-451.

HALEY, J. (1993). Reawakening the spirit at work. San Francisco: BerrettKoehler.

HALL, D.E. (2002). The Academic self: an owner's manual. Ohio: The Ohio State University Press.

HAYEK, F. (1952). The Sensory order: an inquiry into the foundations of theoretical psychology. Chicago: The University of Chicago Press.

HAZY, J.K. (2006). Measuring leadership effectiveness in complex socio-technical systems. Emergence: complexity and organization, v.8, n.3, p.58-77.

HECKSCHER, C. (1994). Defining the post-bureaucratic type. In: HECKSCHER, C.; DONNELLON, A. (Ed.). The Post-bureaucratic organization: new perspectives on organizational change. Newbury Park: Sage. p. 14-62

HERSEY, P.; BLANCHARD, K.H. (1969). Management of organizational behavior - utilizing human resources. New Jersey: Prentice Hall. 
HERSEY, P.; BLANCHARD, K.; JOHNSON, D.E. (1996). Management of organizational behavior: utilizing human resources. $7^{\text {th }}$ ed. Englewood Cliffs: Prentice-Hall.

HERZBERG, F.; MAUNSER, B.; SNYDERMAN, B. (1959). The Motivation to work. New York: John Wiley.

HESBURGH, T. (1988). Academic leadership. New Directions for Higher Education, v.61, n.1, p.5-8.

HIRSCH, E.D. (2002). The New dictionary of cultural literacy. $3^{\text {rd }}$ ed. Boston: Houghton Mifflin.

HISLOP, D. (2005). Knowledge management in organizations: a critical introduction. New York: Oxford University Press.

HOLLAND, J.H. (2006). Studying complex adaptive systems. Journal of Systems Science and Complexity, v.19, n.1, p.1-8.

HOUSE, R.J. (1971). A Path-goal theory of leader effectiveness. Administrative Science Quarterly, v.16, p.321-339. DOI:10.2307/2391905.

HOUSE, R.J. (1977). A 1976 Theory of charismatic leadership. In: HUNT, J.G.; LARSON, L.L. (Ed.). Leadership: the cutting edge. Carbondale: Southern Illinois University Press. p.189-204.

HOUSE, R.J.; BAETZ, M. (1979). Leadership: some empirical generalizations and new research directions. In: STAW, B.M. (Ed.). Research in organizational behavior. Greenwich: JAI. v.1, p.341-423.

HOUSE, R.J.; MITCHELL, T.R. (1974). Path-goal theory of leadership. Journal of Contemporary Busyness, v.3, n.3 , p.81-97.

HOWELL, J.M.; AVOLIO, B.J. (1993). Transformational leadership, transactional leadership, locus of control, and support for innovation: key predictors of consolidated business-unit performance. Journal of Applied Psychology, v.78, n. 6 , p.891-902.

IOCHIDA, L.C. (2000). Aprendizado baseado em problemas (PBL Website). São Paulo: Centro de Desenvolvimento do Ensino Superior em Saúde (CEDESS)/Universidade Federal de São Paulo/Escola Paulista de Medicina. Disponível em:<http://www.unifesp.br/centros/cedess/pbl/>. Acesso em: 23 mar. 2013.

IREY, R.K. (1987). Four principles of effective teaching. Engineering Education, n.285, p. 143-147, Feb.

JOHANSEN, R. (1989). User approaches to computer- supported teams. In: JOHNSON, G.M.; KULPA, A. (2007). Dimensions of online behavior: toward a 
user typology. CyberPsychology Behavior, and Social Newtworking, New Rochelle, v.10, n.6, p.773-770, Dec.

JOHNSON, N.F. (2007). Two's company, three is complexity: z simple guide to the science of all sciences. Oxford: Oneworld.

KAPLAN, A.M.; HAENLEIN, M. (2010). Users of the world, unite! The challenges and opportunities of social media. Business Horizons, v.53, n.1, p.59-68.

KARK, R.; SHAMIR, B.; CHEN, G. (2003). The Two faces of transformational leadership: empowerment and dependency. Journal of Applied Psychology, Washington, v.88, n.2, p.246-255, Apr.

KELLY-GANGI, C.; PATTERSON, J. (2001). Celebrating teachers: a book of appreciation. New York: Barnes \& Noble.

KEYNES, J.M. (1983). O Fim do "laissez-faire". In: SZMRECSÁNYI, T. (Org.). Keynes (Economia). São Paulo: Ática. p.106-126.

KING, W.R.; CHUNG, T.R.; HANEY, M.H. (2008). Knowledge management and organizational learning. Omega: The International Journal of Management Science, v.36, n.2, p.167-172.

KLEIN, K.J. et al. (2011). When team members' values differ: the moderating role of team leadership preface. Organizational Behavior and Human Decision Processes, Amsterdam, v.114, n.1, p.25-36, Jan.

KOLSTOE, O.P. (1975). College docenteing: or, through academia with gun and camera. Carbondale: Southern Illinois University Press.

KOTTER, J.P. (1996). Leading change. Boston: Harvard Business School Press. (1995). The Leadership challenge: how to keep getting extraordinary things done in organizations. San Francisco: Jossey-Bass.

KOUZES, J.M.; POSNER, B.Z. (1995). Exemplary leaders: they model the way for others. Executive Excellence, v.21, n.6, p.1.

LAABS, J. (1999). Taking a stand for leadership. Workforce, v.78, n.5, p.23-35.

LEONARD, D.; SENSIPER, S. (2002). The Role of tacit knowledge in group innovation. In: CHOO, C.W.; BONTIS, N. (2002). The Strategic management of intellectual capital and organizational knowledge. New York: Oxford University Press. p.485-499.

LISSACK, M.R.; ROOS, J. (2000). The Next common sense, the e-manager's guide to mastering complexity. Boston: Intercultural.

LORENZ, E.N. (1963). Deterministic non-periodic flow. Journal of the Atmospheric Sciences, v.20, n. , p.130-141. 
LUTHANS, F.; AVOLIO, B. (2003). Authentic leadership: a positive development approach. In: CAMERON, K.S.; DUTTON, J.E.; QUINN, R.E. (Ed.). Positive organizational scholarship. San Francisco: CA7 Berrett-Koehler. p.241-258.

MACKENZIE, K.D.; HOUSE, R.J. (1975). Paradigm development in the social sciences: a proposed research strategy. Toronto: University of Toronto. (Working Paper \#75-03).

MALHOTRA, N.K. (2001). Pesquisa de marketing: uma orientação aplicada. Management Journal, v.37, n.1, p.18-23, First quarter.

MARION, R. (1999). The Edge of organization: chaos and complexity theories of formal social organization. Newbury Park: Sage.

MARION, R.; UHL-BIEN, M. (2001). Leadership in complex organizations.

Leadership Quarterly, v.12, n. 12 , p.389-418.

MARION, R.; UHL-BIEN, M. (2003). Complexity theory and Al-Qaeda: examining complex leadership. Emergence: Complexity Issues in Organizations and Management, v.5, n.4 , p.56-78.

MARTIN, E. et al. (2003). Variation in the experience of leadership of teaching in higher education. Studies In Higher Education, v.28, n.3, p.247-259.

MASON, C.M.; GRIFFIN, M.A. (2002). Identifying group task satisfaction at work. Small Group Research, v.34, n.30 , p.413-442.

MASETTO, M. T. (1996). A aula na universidade. In: ENDIPE, 8., Anais, Florianópolis, v. 2, p. 323-330.

MCCRAE, R.R.; COSTA, P.T. (1997). Personality trait structure as a human universal. American Psychologist, v.52, p.509-516.

MCELROY, M.W. (2003). The New knowledge management: complexity, learning, and sustainable innovation. Burlington: Butterworth-Heinemann.

MCKEACHIE, W.J. (1986). Teaching tips. $8^{\text {th }}$ ed. Lexington: D.C.Heath.

MCKECHIE, W.J.; BROWN, D.R.; PINTRICH, P.R. (1994). Student

motivation,cognition and learning: essays in honour of Wilbert J.McKechie.

Hillsdale: Lawrence Erlbaum.

MCKEE, R.; CARLSON, B. (1999). The Power to change. Austin: Grid International.

MCKELVEY, B. (2011). Microstrategy from macroLeadership: distributed intelligence via new science. In: LEWIN, A.Y.; VOLBERDA, H. (Ed.). Mobilizing the self-renewing organization. Thousand Oaks: Sage. 
MEDRANO, L.A.C. (2010). Modelo integrado para a implantação e desenvolvimento da gestão do conhecimento. Dissertação (Mestrado) -Escola de Engenharia de São Carlos, Universidade de São Paulo, São Carlos, 2010.

MEINDL, J.R.; EHRLICH, S.B.; DUKERICH, J.M. (1985). The Romance of leadership. Administrative Science Quarterly, v.30, n.1, p.78.

MENNIN, S.; MAJOOR, G. (2002). Problem-based learning/portuguese translation aprendizagem baseada em problemas - ABP. Tradução de Gladis Bottaro Angel; Regina Helena Petroni Mennin. (The Network - Towards Unity for Health - Position Paper).

MICHEL, M.C.; BISCHOFF, A.; JAKOBS, K.H. (2002). Comparison of problemand lecture-based pharmacology teaching. Trends Pharmacology Science, v.23, n.4, p.168-170, Apr.

MINAYO, M.C.S. (1996). O Desafio do conhecimento: pesquisa qualitativa em saúde. 4.ed. São Paulo: Hucitec-Abrasco.

MOXLEY, R.S. (2000). Leadership and spirit. San Francisco: Jossey-Bass.

MURRAY, H. (2002). Emotional Intelligence is fundamental to effective leadership. Occasional Paper: changing leadership constructs in the 21st century: reimaging roles, relationships and redefining professional development, n.1, p.49-66 .

NEWCOMBE, M.J.; ASHKANASY, N.M. (2002). The Role of affect and affective congruence in perceptions of leaders: an experimental study. The Leadership Quarterly, v.13, n.5, p.601-614.

NONAKA, I. (1991). The Knowledge-creating company. Harvard Business Review, v.69, n. 6, p.96-104, Nov./Dec.

(2002). A Dynamic theory of organizational knowledge creation. In: CHOO, C.W.; BONTIS, N. (2002). The Strategic management of intellectual capital and organizational knowledge. New York: Oxford University Press. p.437-462.

NONAKA, I.; TAKEUCHI, H. (1995). The Knowledge creating company: how Japanese companies create the dynamics of innovation. New York: Oxford University Press.

. (2011). The Wise leader: how CEOs can learn practical wisdom to help them do what's right for their companies - and society (The Big Idea). Harvard Business Review, Boston, v.89, n.5, p.58-67, May.

O'REILLY, T. (2005). What is web 2.0? Design patterns and business models for the next generation of software. Disponível em:<www.oreillynet.com/pub/a/oreilly/tim/news/ 2005/09/30/what-is-web-20.html>. Acesso em: 1 Sept. 2011. 
OBERG, W. (1972). Charisma, commitmente, and contemporary organization theory. Business Topics, v.20, n. 4 , p.18-32.

OWEN, M. et al. (2006). Social software and learning. Bristol: Futurelab.

PALMER, P.J. (1983). To Know as we are known: a spirituality of education. San Francisco: Harper Collins.

PARK, S.H. (2006). Impact of problem-based learning (PBL) on teachers' beliefs regarding technology use. $171 \mathrm{f}$. Thesis (Doctoral in Philosophy) Faculty of Purdue University, West Lafayette, Indiana, 2006.

PELLICIARI, M.R.M. ; CAZARINI, E.W. (2011) O Docente como líder transformacional: estudo de caso em um ambiente virtual de colaboração na engenharia. In: SIMPÓSIO DE ENGENHARIA DE PRODUÇÃO,18., Bauru. Anais... Bauru: UNESP/FEP. v.1, p.89.

PÉREZ LÓPEZ, S.; MONTES PEÓN; J.M.; VAZQUEZ ORDÁS, C.J. (2005). Organizational learning as a determining factor in business performance. The Learning Organization, v.12, n.3, p.227-245.

PESCOSOLIDO, A.T. (2002). Emergent leaders as managers of group emotion. The Leadership Quarterly, v.13, n.5, p.583-599.

PETERS, T.J.; WATERMAN, Jr., R.H. (1982). In Search of excellence: lessons from America's best-run companies. New York: Harper \& Row.

POIKELA, E.; POIKELA, S. Conceptions of learning and knowledge-impacts on the implementation of problem-based learning. Zeitschrift fur Hochschuldidactik, v.1, p.8-21, 1997.

POLANYI, M. (1958). Personal knowledge. Chicago: Chicago University Press.

(1966). The Tacit dimension. London: Routledge and Kegan Paul.

PORTER, M.E. (1979). How competitive forces shape strategy: awareness of these forces can help a company stake out a position in its industry that is less vulnerable to attack. Harvard Business Review, Boston, v.57, p.137-145, Mar./Apr.

PORTER-O'GRADY, T.; MALLOCH, K. (2003). Quantum leadership: a textbook of new leadership. Sudbury: Jones and Barlelt. p.27

POUNDER, J.S. (2001). New leadership and university organisational effectiveness: exploring the relationship. Leadership \& Organization Development Journal, v.22, n.6, p.281-290. 
PRIGOGINE, I. (1997). The End of certainty. New York: Free Press.

PURVANOVA, R.K.; BONO, J.E. (2009). Transformational leadership in context: face-to-face and virtual teams. Leadership Quarterly, Amsterdam, v.20, n.3, p.343-357, June.

QUINN, J.B. (1992). Intelligent enterprise, a knowledge and service based paradigm for industry. New York: The Free.

RAMSDEN, P. (1998). Learning to lead in higher education. London: Routledge.

RANTZ, R. (2002). Leading urban institutions of higher education in the new millenium. Leadership and Organization Development Journal, v.23, n.8, p.456-466.

RECUPERO, P.R. (2010). The Mental status examination in the age of the internet. Journal of the American Academy of Psychiatry and the Law, Bloomfield, v.38, n.1, p.15-26, Mar.

REGINE, B.; LEWIN, R. (2000). Leading at the edge: how leaders influence complex systems. Emergence: a Journal of Complexity Issues in Organizations and Management, v.2, n. 2 , p.5-23.

RIBEIRO, L.R.C. (2005). A aprendizagem baseada em problemas(PBL): uma implementação na educação em engenharia na voz dos autores. São Carlos, 2005. 209 p. Tese (Doutorado em Educação) - Programa de Pós-Graduação em Educação, Universidade Federal de São Carlos UFSCar, 2005.

RIVERA, J.C.; MCALISTER, M.K. (2001). A Comparison of student outcomes and satisfaction between traditional and web based course offerings. In:

INFORMATION RESOURCES MANAGEMENT ASSOCIATIONINTERNATIONAL CONFERENCE, 2001, Ontario. Proceedings... Ontario: Idea.

ROCHA, L.M. (1999). BITS: computer and communications news. Los Alamos: National Laboratory; Computing, Information, and Communications Division.

RODRIGUES, M.L.V.; FIGUEIREDO, J.F.C. (1996). Aprendizado centrado em problemas. Medicina, Ribeirão Preto, v.29, p.396-402, out./dez.

ROWLEY, D.J.; SHERMAN, H. (2003). The Special challenges of academic leadership. Management Decision, v.41, n.10, p.1058-1063.

SAKAI, M.H.; LIMA, G.Z. (1996). PBL uma visão geral do método. Olho Mágico, Londrina, v.2, n.5/6, nov. Número especial.

SAVERY J. R.; DUFFY, T. M. (1998). Problem-based learning: an instructional model and its constructivist framework. In: FOGARTY, R. (ed.). Problem-based learning: a collection of articles. Arlington Heights: Skylight, p. 72-92. 
SCHRAMM, W. (1971). Notes on case studies of instructional media projects. Washington: The Academy for Educational Development. (Working paper).

SCHWARTZ, P.; MENNIN, S.; WEBB, G. (Ed.). (2001). Problem-based learning: case studies, experience and practice. Londres: Kogan Page. p.142-150.

SEGAL, L. (1994). Effects of checklist interface on non-verbal crew communications. Washington: NASA Ames Research Center. (Contractor Report 177639).

SEGERS, M.S.R. Assessment in a problem-based economics curriculum. In: BIRENBAUM, M.; DOCHY, F. (Ed.). Alternatives in assessment of achievements, learning processes and prior learning. Boston: Kluwer Academic, 1996. p.201-226.

SELLTIZ, C; WHRIGHTSMAN, L S.; COOK, S W. (1987). Métodos de pesquisas nas relações sociais. São Paulo: EPU.

SENGE, P.M. (1990). A Quinta disciplina. São Paulo: Best Seller.

SHAHMANDI, E. et al. (2011). Competencies, roles and effective academic leadership in world class university. International Journal of Business Administration, v.2, n. 3 , p.44-53.

SHILS, E.A. (1965). Charisma, order, an status. American Sociological Review, v.30, n. 2 , p.199-213.

SCHMIDT, H. G. (1993). Foundations of problem-based learning: some explanatory notes. Medical Education, v. 27, p. 422-432.

SIMON, H.A. (1979). Information processing models of cognition. Annual Review Psychology, v.30, n. 33 , p.363.

SMITH, M. (1991). Situational leadership training. Journal of Managemente in Engineering, v.7, n. 1 , p.365.

SNOWDEN, D. (2002). Complex acts of knowing: paradox and descriptive selfawareness. Journal of Knowledge Management, v.6, n.2, p.00-111.

SPENCER, H. (1896). The Study of Sociology. New York: Appleton.

SPENDER, J.C. (2002). Knowledge management, uncertainty, and an emergent theory of the firm. In: CHOO, C.W.; BONTIS, N. (2002). The Strategic management of intellectual capital and organizational knowledge. New York: Oxford University Press. p.149-162.

SPRINGER L.; STANNE, M.E.; DONOVAN, S.S. (1999). Effects of small-group learning on undergraduates in science, mathematics, engineering, and technology: a meta-analysis. Review of Educational Research, v.69, n.1, p.21-51. 
SPROULL, L.; KIESLER, S. (1991). Connections. Cambridge: MIT.

STACEY, R. (2001). Complex responsive processes in organizations: learning and knowledge creation. London: Routledge.

STAIGER, E.H. (1984). Probing more of the mind. Engineering Education, v.65, n. 7, p. $651-65$, Apr.

STRAKER, D. (2012). Great man theory: changing minds. Disponível em:<http://changingminds.org/disciplines/leadership/theories/great_man_theory.ht m>. Acesso em: 5 Jan. 2012.

STUTZMAN, F. et al. (2011). Factors mediating disclosure in social network sites. Computers in Human Behavior, Amsterdam, v.27, n.1, p.590-598, Jan.

SWENSON, P. W.; EVANS, M. (2003). Hybrid courses as learning communities. In S. REISMAN; J. G. FLORES; D. EDGE (Eds.). Electronic learning communities: Issues and practices. Greenwich, CT: Information Age Publishing. p. 27-71.

TARADI, S.K. et al. (2005). Blending problem-based learning with web technology positively impacts student learning outcomes in acid-base physiology. Advances in Physiology Education, v.29, n.1, p.35-39.

TSOUKAS, H. (2005). Do we really understand tacit knowledge?. In: TSOUKAS, H. (Ed.). Complex knowledge: studies in organizational epistemology. New York: Oxford University Press. p.141-161.

TUCKER, R.C. (1968). The Theory of charismatic leadership. Daedulus, v.97, n. 3, p.731-756.

TULL, D.S; HAWKINS, D.I. (1976). Marketing Reseach, Meaning, Measurement and Method. London: Macmillan. p.323.

TYNJÄLÄ, P. (1999). Towards expert knowledge? A Comparison between a constructivist and a traditional learning environment in the University.

International Journal of Educational Research, v.31, n.5, p.357-442.

UHL-BIEN, M.; MARION, R.; MCKELVEY, B. (2004). Complexity leadership theory: shifting leadership from the industrial age to the knowledge era. The Leadership Quarterly, v.18, n.4, p. 298-318

VERGARA, S.C. (2005). Métodos de pesquisa em administração. São Paulo: Atlas.

VERNON, D.T.A.; BLAKE, R.L. (1993). Does problem-based learning work? A Meta-analysis of evaluative research. Academic Medicine, v.68, n.7, p.550-563, July 1993.

VYGOTSKY, L.S. (1978). Mind in society: the development of higher psychological processes. Cambridge: Harvard University Press. 
WALES, C.E. (1976). Improve your teaching tomorrow with teaching-learning psychology. Engineering Education, v.390, n.4, p.107. Feb.

WANKAT, P.C.; OREOVICZ, F.S. (1992a). Teaching engineering. New York: McGraw-Hill College. Cap.5, p.69-70. (1992b). New York: McGraw-Hill College. Cap.15, p.297-298.

WEAVER, W. (1948). Science and complexity. American Scientist, v.36, p.536. Disponível em:<http:/ / www. ceptualinstitute. com/ genre/ weaver/ weaver-1947b. htm>. Acesso em: 20 Dec. 2011.

WEBER, M. (1947). The Theory of social and economic organization. New York: Free Press.

WELLMAN, B. (2004). Studying the internet through the ages. Disponível em:<http://homes.chass.utoronto.ca/ wellman/publications $>$. Acesso em: 15 July 2011.

WHAT Works. (1986). Washington: U.S. Department of Education.

WIGGIO (2011). Disponível em:<http://wiggio.com>. Acesso em: 01 July 2011.

WILSON, E.O. (1998). Consilience: the unity of knowledge. New York: Alfred A. Knopf.

WITTROCK, M.C. (1989). Generative processes of comprehension. Educational Psychologist, v.24, n.4, p.345-376.

YIN, R.K. (2001). Estudo de caso - planejamento e método. 2.ed. São Paulo: Bookman.

ZACCARO, S.J.; BURKE, C.S. (1998). Teamversus crew leadership: differences and similarities. In: KLIMOSKI, R.J. When is a work team a crew-and does it matter?. Paper presented at the $13^{\text {th }}$ Annual Conference of the Society for Industrial and Organizational Psychology, Dallas, 1998. 


\section{APÊNDICES}

Apêndice 1 - Questão 1 - Análise do Índice de Satisfação de Grupo (MASON; GRIFFIN, 2002), Sub-questões de 1.2 a 1.12

Apêndice 2 - Questão 2 - Percepção individual em relação ao docente da disciplina", Sub-questões de 2.1 a 2.8

Apêndice 3 - Questão 3 - Minha percepção individual em relação aos ambientes virtuais de colaboração utilizados Sub-questões de 3.1 a 3.6 - Ano 2011

Apêndice 4 - Questão 3 - "Minha percepção individual em relação aos ambientes virtuais de colaboração utilizados Sub-questões de 3.1 a 3.6 - Ano 2012

Apêndice 5 - Outras mídias sociais utilizadas durante o semestre e espaço para sugestões e críticas

Apêndice 6 - Uso do Google+ e outros serviços Google por Estudantes da EESC-USP em três disciplinas do $2^{\circ}$ semestre de 2011 do curso de Engenharia de Produção: Sistemas de Informação ( $2^{\circ}$ ano); Sistemas de Apoio a Decisão ( $4^{\circ}$ ano e Pós)

Apêndice 7 - Uso do Google+ e outros serviços Google por Estudantes da EESC-USP em três disciplinas do $2^{\circ}$ semestre de 2011 do curso de Engenharia de Produção: Sistemas de Informação ( $2^{\circ}$ ano); Sistemas de Apoio a Decisão ( $4^{\circ}$ ano e Pós $)$ Grupos com melhores avaliações

Apêndice 8 - Uso do Google+ e outros serviços Google por Estudantes da EESC-USP em três disciplinas do $2^{\circ}$ semestre de 2011 do curso de Engenharia de Produção: Sistemas de Informação ( $2^{\circ}$ ano); Sistemas de Apoio a Decisão ( $4^{\circ}$ ano e Pós $)$ Grupos com piores avaliações 
Em uma escala de 5 (cinco) graus entre Discordo Plenamente e Concordo Plenamente, assinale cada alternativa:

QUESTÃO 1: "Minha percepção individual em relação à minha equipe no cumprimento dos desafios da disciplina"

1.1. $O$ trabalho foi rotineiro e entediante

\begin{tabular}{|c|c|c|c|c|}
\hline Discordo Plenamente & Discordo & Indiferente & Concordo & Concordo Plenamente \\
\hline
\end{tabular}

1.2. Nosso grupo percebeu que podia se beneficiar bastante do trabalho desenvolvido

\begin{tabular}{|c|c|c|c|c|}
\hline Discordo Plenamente & Discordo & Indiferente & Concordo & Concordo Plenamente \\
\hline
\end{tabular}

1.3. O relacionamento interpessoal entre membros do grupo causou insatisfação para esse grupo

\begin{tabular}{l|l|l|l|l} 
Discordo Plenamente & Discordo & Indiferente & Concordo & Concordo Plenamente
\end{tabular}

1.4. Nosso grupo está feliz com o caminho que trabalhamos juntos como um time

\begin{tabular}{|l|c|c|c|c|}
\hline Discordo Plenamente & Discordo & Indiferente & Concordo & Concordo Plenamente \\
\hline \multicolumn{5}{|c|}{ 1.5. Nosso grupo ficou insatisfeito com o ambiente de trabalho } \\
\hline Discordo Plenamente & Discordo & Indiferente & Concordo & Concordo Plenamente \\
\hline
\end{tabular}

1.6. Nosso grupo está mais entusiasmado sobre esse trabalho que outros grupos

\begin{tabular}{|l|c|c|c|c|}
\hline Discordo Plenamente & Discordo & Indiferente & Concordo & Concordo Plenamente \\
\hline \multicolumn{5}{|c|}{ 1.7. Nosso grupo está satisfeito com as condições de trabalho } \\
\hline Discordo Plenamente & Discordo & Indiferente & Concordo & Concordo Plenamente \\
\hline
\end{tabular}

1.8. Nosso grupo aproveitou os aspectos sociais do trabalho em equipe

\begin{tabular}{|c|c|c|c|c|}
\hline Discordo Plenamente & Discordo & Indiferente & Concordo & Concordo Plenamente \\
\hline
\end{tabular}

1.9. Nosso grupo experimentou frustração quando tentou trabalhar em equipe

\begin{tabular}{|c|c|c|c|c|}
\hline Discordo Plenamente & Discordo & Indiferente & Concordo & Concordo Plenamente \\
\hline
\end{tabular}

1.10. Nosso grupo esperava mais reconhecimento e mais recompensas por parte do líder

\begin{tabular}{|c|c|c|c|c|}
\hline Discordo Plenamente & Discordo & Indiferente & Concordo & Concordo Plenamente \\
\hline
\end{tabular}

1.11. Nosso grupo manteve-se motivado e interessado no trabalho

\begin{tabular}{|l|l|l|l|l} 
Discordo Plenamente & Discordo & Indiferente & Concordo & Concordo Plenamente \\
\hline
\end{tabular}

1.12. Nosso grupo teve atitudes positivas frente aos desafios e condiçóes de trabalho

\begin{tabular}{|l|l|l|l|l|} 
Discordo Plenamente & Discordo & Indiferente & Concordo & Concordo Plenamente \\
\hline
\end{tabular}

(Questão 1 traduzida livremente e adaptada por Marcos Pelliciari e Edson Walmir Cazarini de Mason, C. M., \& Griffin M. A. (2003).

Identifying group task satisfaction at work. Small Group Research, 34, 413-442)

Apêndice 1 - Análise do Índice de Satisfação de Grupo (MASON; GRIFFIN, 2002), Questão 1, Sub-questões de 1.2 a 1.12 
Em uma escala de 5 (cinco) graus entre Discordo Plenamente e Concordo Plenamente, assinale cada alternativa:

QUESTÃO 2: "Minha percepção individual em relação ao professor da disciplina"

2.1. "Deixou rolar" e não interferiu em meu trabalho

\begin{tabular}{|c|c|c|c|l|}
\hline Discordo Plenamente & Discordo & Indiferente & Concordo & Concordo Plenamente \\
\hline
\end{tabular}

2.2. Apresentou um carisma que me inspirava

\begin{tabular}{|l|l|l|l|l}
\hline Discordo Plenamente & Discordo & Indiferente & Concordo & Concordo Plenamente
\end{tabular}

2.3. Motivou-me em grande parte dos desafios

\begin{tabular}{|c|c|c|c|c|}
\hline Discordo Plenamente & Discordo & Indiferente & Concordo & Concordo Plenamente \\
\hline
\end{tabular}

\subsection{Estimulou-me intelectualmente}

\begin{tabular}{|l|l|l|l|l} 
Discordo Plenamente & Discordo & Indiferente & Concordo & Concordo Plenamente \\
\hline
\end{tabular}

2.5. Procurou ajudar-me de forma individualizada

\begin{tabular}{|l|l|l|l|l|}
\hline Discordo Plenamente & Discordo & Indiferente & Concordo & Concordo Plenamente \\
\hline
\end{tabular}

2.6. Esclareceu as expectativas em relação à disciplina e negociou as recompensas se as mesmas fossem alcançadas \begin{tabular}{|l|l|l|l|l} 
Discordo Plenamente & Discordo & Indiferente & Concordo & Concordo Plenamente \\
\hline
\end{tabular}

2.7. Esperava um determinado problema se instalar para tomar providências

\begin{tabular}{|l|l|l|l|l} 
Discordo Plenamente & Discordo & Indiferente & Concordo & Concordo Plenamente \\
\hline
\end{tabular}

2.8. Percebia que um problema estava se instalando e agia antes que o problema se agravasse

\begin{tabular}{|l|l|l|l|l|} 
Discordo Plenamente & Discordo & Indiferente & Concordo & Concordo Plenamente \\
\hline
\end{tabular}

Apêndice 2 - Percepção individual em relação ao docente da disciplina, Sub-questões de 2.1 a 2.8 
Em uma escala de 5 (cinco) graus entre Discordo Plenamente e Concordo Plenamente, assinale cada alternativa:

QUESTÃO 3 (Ano 2011): "Minha percepção individual em relação aos ambientes virtuais de colaboração utilizados"

3.1. Me aderi ao Google+ e utilizei constantemente o serviço para realizar minhas tarefas em grupo

\begin{tabular}{|l|l|l|l|l} 
Discordo Plenamente & Discordo & Indiferente & Concordo & Concordo Plenamente
\end{tabular}

3.2. O Moodle me proporciona mais motivação para trabalhar em equipe do que o Google+

\begin{tabular}{|l|l|l|l|l} 
Discordo Plenamente & Discordo & Indiferente & Concordo & Concordo Plenamente
\end{tabular}

3.3. Não utilizei o Google + porque percebi que não haveria punição se não o fizesse

\begin{tabular}{|l|l|l|l|l} 
Discordo Plenamente & Discordo & Indiferente & Concordo & Concordo Plenamente
\end{tabular}

3.4. Creio que o Facebook seja mais adequado que o Google+ para se trabalhar em equipe em uma disciplina

\begin{tabular}{|l|l|l|l|l} 
Discordo Plenamente & Discordo & Indiferente & Concordo & Concordo Plenamente
\end{tabular}

3.5. Não explorei a fundo as possibilidades do Google+ porque achei o Site complicado

\begin{tabular}{|l|l|l|l|l} 
Discordo Plenamente & Discordo & Indiferente & Concordo & Concordo Plenamente
\end{tabular}

3.6. O Moodle é um ambiente virtual de aprendizagem no qual me sinto confortável

\begin{tabular}{|l|l|l|l|l} 
Discordo plenamente & Discordo & Indiferente & Concordo & Concordo plenamente
\end{tabular}

Apêndice 3 - Percepção individual em relação aos ambientes virtuais de colaboração utilizados, Sub-questões de 3.1 a 3.6 - Ano 2011 
QUESTÄO 3: "Minha percepção individual em relação aos ambientes virtuais de colaboração utilizados" - Ano 2012

3.1. Me aderi ao Facebook e utilizei constantemente o serviço para realizar minhas tarefas em grupo \begin{tabular}{|l|l|l|l|l} 
Discordo Plenamente & Discordo & Indiferente & Concordo & Concordo Plenamente
\end{tabular}

3.2. O Moodle me proporciona mais motivação para trabalhar em equipe do que o Facebook \begin{tabular}{|l|l|l|l|l} 
Discordo Plenamente & Discordo & Indiferente & Concordo & Concordo Plenamente
\end{tabular}

3.3. Não utilizei o Facebook porque percebi que não haveria punição se não o fizesse

\begin{tabular}{|l|l|l|l|l} 
Discordo Plenamente & Discordo & Indiferente & Concordo & Concordo Plenamente \\
\hline
\end{tabular}

3.4. Creio que o Facebook seja mais adequado que o Google+ para se trabalhar em equipe em uma disciplina \begin{tabular}{|l|l|l|l|l} 
Discordo Plenamente & Discordo & Indiferente & Concordo & Concordo Plenamente
\end{tabular}

3.5. Não explorei a fundo as possibilidades do Google+ porque achei o Site complicado \begin{tabular}{|l|l|l|l|l} 
Discordo Plenamente & Discordo & Indiferente & Concordo & Concordo Plenamente
\end{tabular}

3.6. O Moodle é um ambiente virtual de aprendizagem no qual me sinto confortável

\begin{tabular}{l|l|l|l|l} 
Discordo plenamente & Discordo & Indiferente & Concordo & Concordo plenamente
\end{tabular}

Apêndice 4 - Percepção individual em relação aos ambientes virtuais de colaboração utilizados, Sub-questões de 3.1 a 3.6 - Ano 2012 
QUESTÃO 4: Outras mídias sociais que utilizei durante o semestre para o trabalho colaborativo. Ex: MSN, Skype, ...

Sugestões e críticas em relação ao andamento da disciplina

Apêndice 5 - Outras mídias sociais utilizadas durante o semestre e espaço para sugestões e críticas 


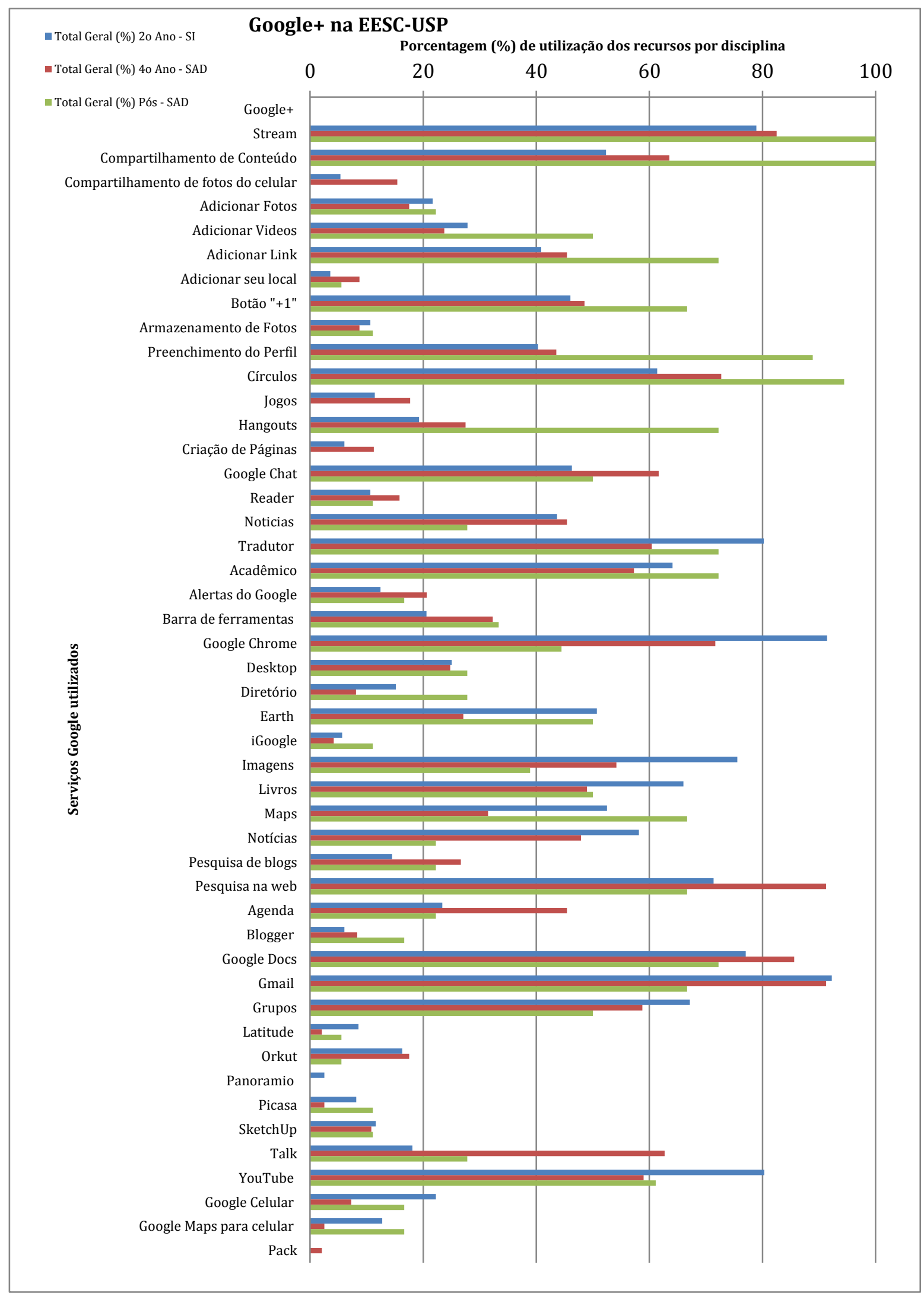

Apêndice 6 - Uso do Google+ e outros serviços Google por estudantes em três disciplinas do $2^{\circ}$ semestre de 2011 do curso de Engenharia de Produção 


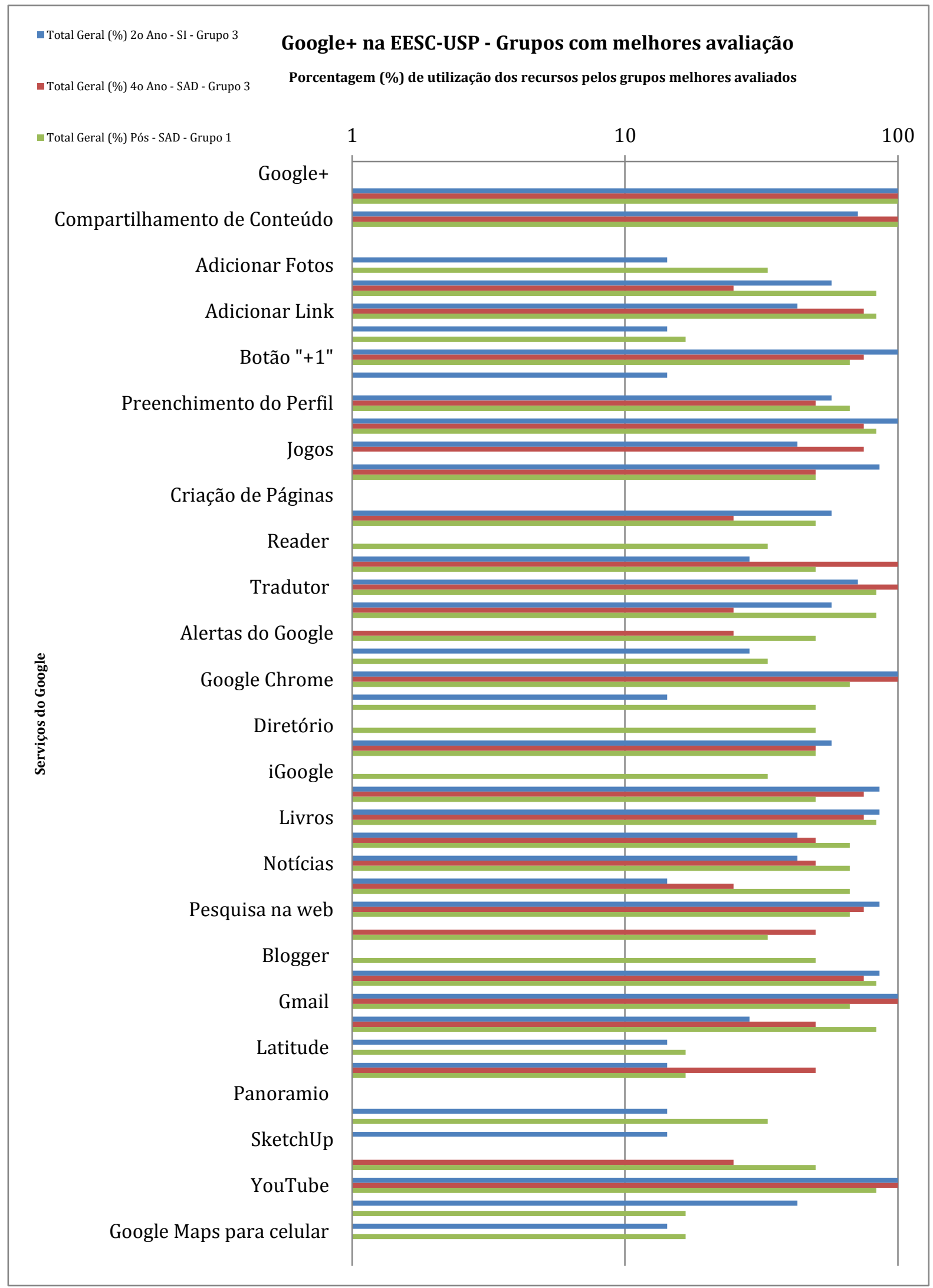

Apêndice 7 - Uso do Google+ e outros serviços Google por estudantes em três disciplinas do $2^{\circ}$ semestre de 2011 do curso de Engenharia de Produção - Grupos com melhores avaliações 
- Total Geral (\%) 20 Ano - SI - Grupo 8

- Total Geral (\%) 40 Ano - SAD - Grupo 4

- Total Geral (\%) Pós - SAD - Grupo 2

\section{Google+ na EESC-USP - Grupos com piores avaliação}

Porcentagem (\%) de utilização dos recursos pelos grupos com piores avaliações

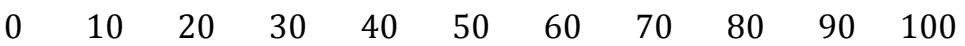

Google+

Compartilhamento de Conteúdo

Adicionar Fotos

Adicionar Link

Botão "+1"

Preenchimento do Perfil

Jogos

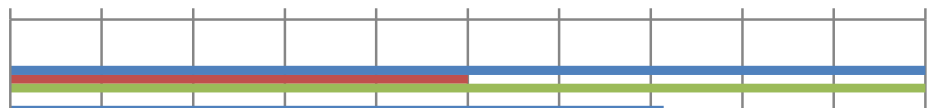

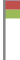

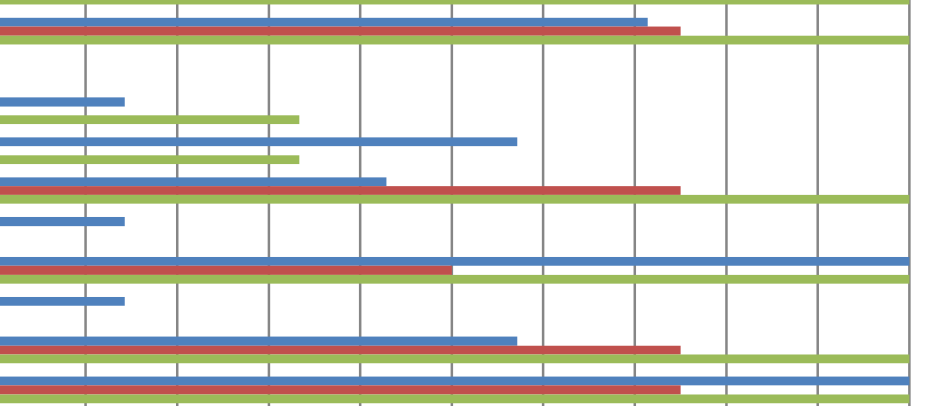

$-$

Criação de Páginas

Reader

Tradutor

Alertas do Google

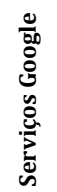

Google Chrome

Diretório

iGoogle

Livros

Notícias

Pesquisa na web

Blogger

Gmail

Latitude

Panoramio

SketchUp

YouTube

Google Maps para celular
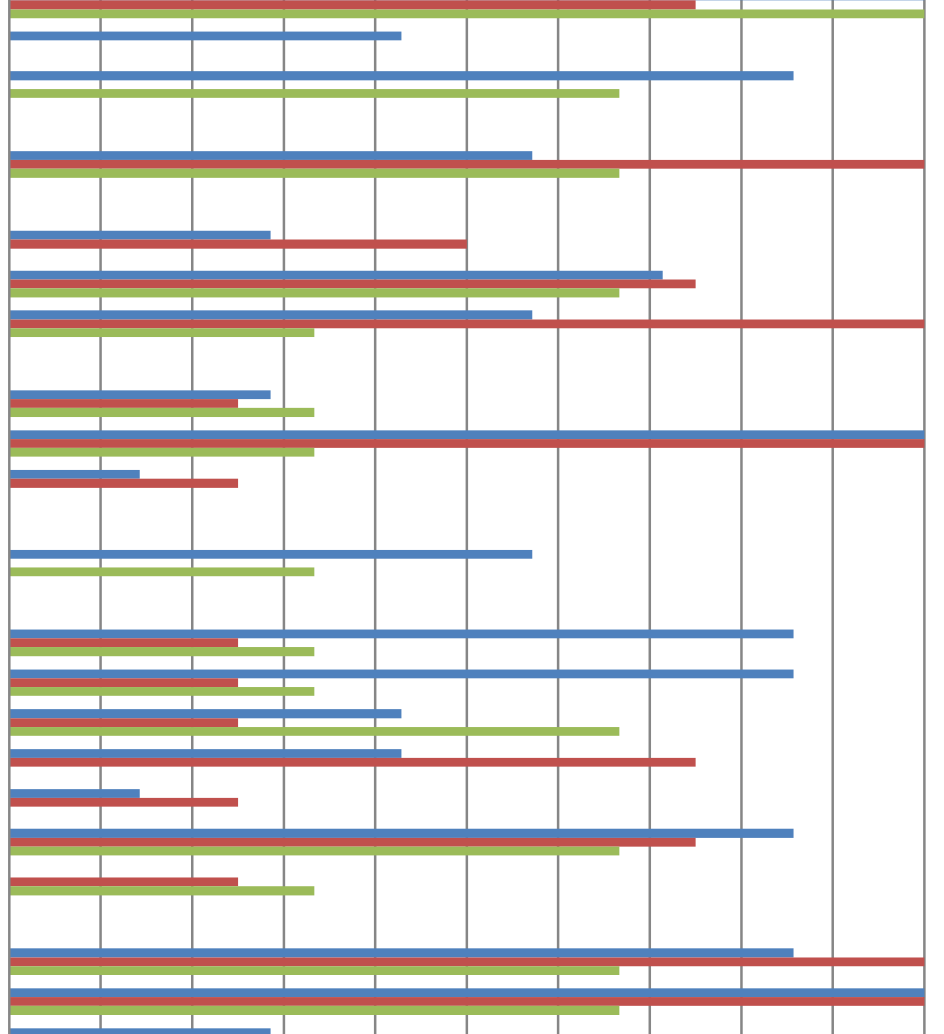

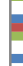

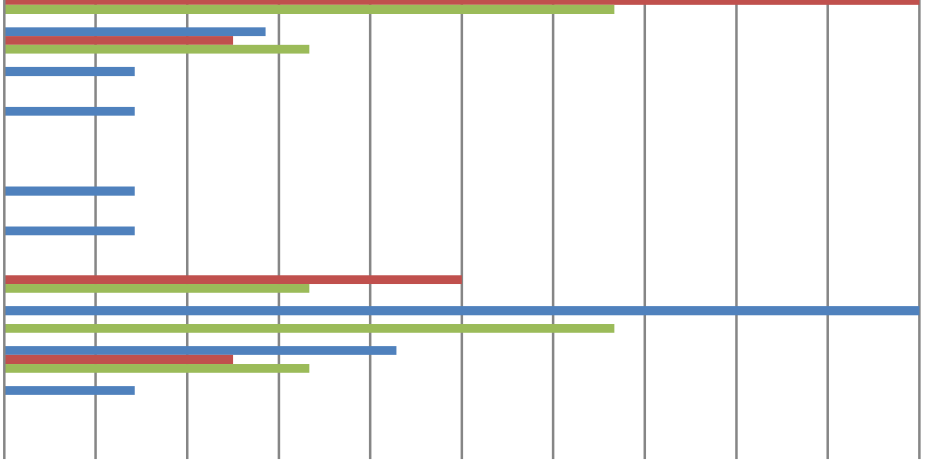

Apêndice 8 - Uso do Google+ e outros serviços Google por estudantes em três disciplinas do $2^{\mathbf{o}}$ semestre de 2011 do curso de Engenharia de Produção - Grupos com piores avaliações 